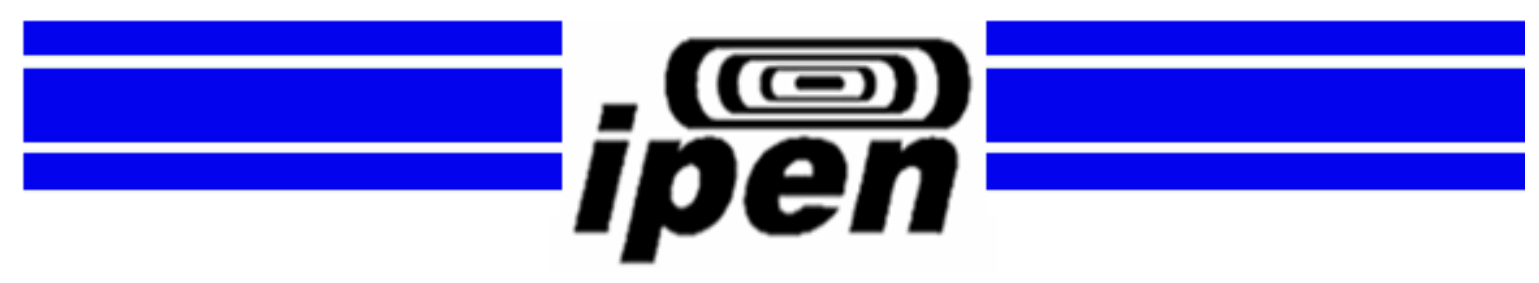

AUTARQUIA ASSOCIADA À UNIVERSIDADE DE SÃO PAULO

\title{
INVESTIGAÇÃO DA ESTABILIDADE DE FASES DA ZIRCÔNIA-ESCÂNDIA
}

\section{ROBSON LOPES GROSSO}

Tese apresentada como parte dos requisitos para obtenção do Grau de Doutor em Ciências na Área de Tecnologia Nuclear - Materiais Orientadora:

Profa. Dra. Eliana Navarro dos Santos Muccillo

São Paulo 2016 
INSTITUTO DE PESQUISAS ENERGÉTICAS E NUCLEARES AUTARQUIA ASSOCIADA À UNIVERSIDADE DE SÃO PAULO

\title{
INVESTIGAÇÃO DA ESTABILIDADE DE FASES DA ZIRCÔNIA-ESCÂNDIA
}

\author{
ROBSON LOPES GROSSO
}

Tese apresentada como parte dos requisitos para obtenção do Grau de Doutor em Ciências na Área de Tecnologia Nuclear - Materiais Orientadora:

Profa. Dra. Eliana Navarro dos Santos Muccillo

Versão Corrigida

Versão Original Disponível no IPEN

São Paulo 2016 
"Life is like riding a bicycle.

To keep your balance you must keep moving." Albert Einstein 


\section{Agradecimentos}

Gostaria de agradecer à Dra. Eliana Navarro dos Santos Muccillo pela oportunidade de desenvolver este trabalho, pelos ensinamentos, dedicação e paciência durante anos de convivência.

Ao Dr. Ricardo Hauch Ribeiro de Castro pela orientação, ensinamentos e oportunidade de estágio na Universidade da Califórnia - Davis.

À FAPESP pela bolsa de doutorado no país \#2012/03319-5 e de estágio de pesquisa no exterior \#2014/24022-6.

Ao IPEN pela oprtunidade de realizar esse trabalho.

Ao Dr. Reginaldo Muccillo pelos ensinamentos, discussões e pelas medidas de difratometria de raios $\mathrm{X}$ e dilatometria.

À Dra. Alexandra Navrotsky pelas discussões sobre calorimetria e pela oportunidade de realizar experimentos de calorimetria em alta temperatura.

Ao Dr. Jivaldo Rosário Matos e Dra. Luci Diva Brocardo Machado pelas medidas de análise térmica e pelas discussões. Ao Dr. Douglas Gouvêa pelas medidas de espectroscopia na região do infravermelho. À Ana Júlia Tertuliano e Dra. Izabel Machado pela sinterização assistida por campo elétrico. À Dra. Sandra Tadokoro, Dra. Renata Ayres Rocha, Dra. Dolores Ribeiro Ricci Lazar e Dra. Érica Caproni pelas discussões e sugestões.

À Companhia Brasileira de Metalurgia e Mineração (CBMM) pela doação dos insumos de nióbio e à empresa japonesa Daiichi Kigenso Kagaku Kogyo (DKKK) pela doação de zircônia-escândia.

Agradeço especialmente à minha mãe e a familiares que me incentivaram e ajudaram. À Raquel Rinke pelo incentivo, apoio e paciência. À família Rinke Santos pelo apoio e momentos de descontração.

A todos os colegas do Nanoceramics Thermochemistry Laboratory pelos treinamentos e pelas incansáveis discussões e contribuições. Aos amigos Dereck e Érica Muche pelo apoio e momentos de descontração.

Aos amigos e colegas de grupo de Eletrocerâmicas: Shirley Reis, Rafael Batista, Tatiane Porfírio, Mayra Gonçalves, Sabrina Carvalho, Talita Fujimoto e Juliana Pereira pelas valiosas discussões, sugestões, apoio e pelos momentos de descontração durante o desenvolvimento deste trabalho. $\mathrm{E}$ a todos que direta ou indiretmente contribuíram para a realização deste trabalho. 


\title{
INVESTIGAÇÃO DA ESTABILIDADE DE FASES DA ZIRCÔNIA-ESCÂNDIA
}

\author{
Robson Lopes Grosso
}

\section{RESUMO}

Nesse trabalho foi proposto investigar a estabilidade de fases do sistema zircôniaescândia (ScSZ) por meio do estudo termodinâmico de nanopartículas, na faixa de 0 a $20 \%$ em mol de $\mathrm{Sc}_{2} \mathrm{O}_{3}$, e a partir da introdução de um segundo aditivo $\left(\mathrm{Dy}_{2} \mathrm{O}_{3}\right.$ e $\left.\mathrm{Nb}_{2} \mathrm{O}_{5}\right)$ ao $\mathrm{ZrO}_{2}$ contendo $10 \%$ em mol de $\mathrm{Sc}_{2} \mathrm{O}_{3}$ (10ScSZ). A estabilidade de fases do ScSZ foi avaliada com base em dados termodinâmicos determinados pelas técnicas de microcalorimetria de adsorção de água e calorimetria de dissolução à alta temperatura. As soluções sólidas foram sintetizadas pelo método de coprecipitação de hidróxidos. Dados termodinâmicos foram determinados para as formas polimórficas encontradas (monoclínica, tetragonal, cúbica, romboédrica $\beta$ e $\gamma$ ) por difração de raios $\mathrm{X}$ no ScSZ. Esse trabalho resultou no diagrama de fases em nanoescala de tamanho de partícula-composição. Os efeitos produzidos pela introdução de aditivos na matriz de 10ScSZ foram investigados visando obter a possível estabilização da estrutura cúbica $(c)$ e a supressão da transformação de fase $c-\beta$, característica do sistema binário. As composições foram sintetizadas por coprecipitação de hidróxidos e por reações em estado sólido para fins comparativos. Os materiais foram sinterizados convencionalmente e por sinterização assistida por campo elétrico. A estabilização completa da fase cúbica ocorreu a partir de teores molares de $1 \%$ de $\mathrm{Dy}_{2} \mathrm{O}_{3}$ e $0,5 \%$ de $\mathrm{Nb}_{2} \mathrm{O}_{5}$. $\mathrm{O}$ menor teor de $\mathrm{Nb}_{2} \mathrm{O}_{5}$ necessário para a estabilização da fase foi atribuído à provável formação da fase líquida durante a sinterização e ao menor tamanho do íon $\mathrm{Nb}^{5+}$. Os resultados de difratometria de raios $\mathrm{X}$ em alta temperatura e análise térmica mostraram que houve supressão da

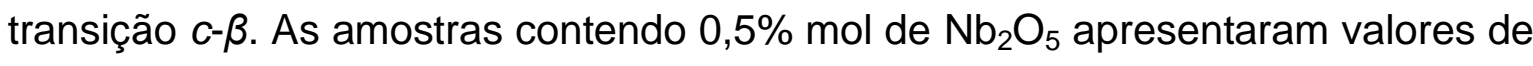
condutividade iônica similares aos do $10 \mathrm{ScSZ}$ sem aditivos em uma ampla faixa de temperatura com elevada estabilidade em um período de $170 \mathrm{~h}$ a $600^{\circ} \mathrm{C}$.

Palavras-chave: zircônia-escândia, microlacorimetria de adsorção de água, diagrama de fases, condutividade iônica. 


\title{
INVESTIGATION OF PHASE STABILITY IN THE SCANDIA-ZIRCONIA
}

\author{
Robson Lopes Grosso
}

\begin{abstract}
In this work, the phase stability of scandia-zirconia (ScSZ) system was investigated by the thermodynamic study of nanoparticles, within the range of 0 to $20 \mathrm{~mol} \% \mathrm{Sc}_{2} \mathrm{O}_{3}$, and by codoping of $\mathrm{ZrO}_{2}-10$ mol\% $\mathrm{Sc}_{2} \mathrm{O}_{3}(10 \mathrm{ScSZ})$ with $\mathrm{Dy}_{2} \mathrm{O}_{3}$ and $\mathrm{Nb}_{2} \mathrm{O}_{5}$. The phase stability of $\mathrm{ScSZ}$ was evaluated based on thermodynamic data collected by water adsorption microcalorimetry and high temperature oxide melt solution. Nanostructured zirconia-scandia solid solutions were synthesized by coprecipitaion method. Thermodynamic data were determined for ScSZ polymorphs (monoclinic, tetragonal, cubic, rhombohedral $\beta$ and $\gamma$ ) found by X-ray diffraction. This systemic work resulted in an unprecedented phase diagram at the nanoscale of particle size-composition. The effects of additives on 10ScSZ were investigated aiming to stabilize the cubic $(c)$ structure at room temperature and to suppress the characteristic cubic-rhombohedral $\beta$ phase transformation. Compositions were prepared by coprecipitation and solid state reaction. Materials were sintered by conventional and spark plasma sintering. Full stabilization of the cubic phase was attained by 1 mol\% $\mathrm{Dy}_{2} \mathrm{O}_{3}$ and $0.5 \mathrm{~mol} \%$ $\mathrm{Nb}_{2} \mathrm{O}_{5}$ additions. The smallest $\mathrm{Nb}_{2} \mathrm{O}_{5}$ content required for cubic phase stabilization was attributed to liquid phase formation during sintering and to small ionic radius of $\mathrm{Nb}^{5+}$. Results of high temperature X-ray diffraction and thermal analysis show suppression of the $c-\beta$ transformation. Samples containing $0.5 \mathrm{~mol} \% \mathrm{Nb}_{2} \mathrm{O}_{5}$ show total ionic conductivity similar to $10 \mathrm{ScSZ}$ without additives within a broad temperature range with high stability during $170 \mathrm{~h}$ at $600{ }^{\circ} \mathrm{C}$.
\end{abstract}

Keywords: scandia-zirconia, water adsorption microcalorimetry, phase diagram, ionic conductivity. 


\section{Lista de Figuras}

Figura 1. Representações esquemáticas da estrutura cúbica tipo fluorita por meio de (a) esferas e (b) cubos. .

Figura 2. Publicações e citações referentes à escândia registrados na Web of Science nos últimos 20 anos.

Figura 3. Representação esquemática da estrutura cúbica tipo C.

Figura 4. Representação esquemática da estrutura monoclínica do $\mathrm{Nb}_{2} \mathrm{O}_{5} \ldots \ldots \ldots . . \quad 8$

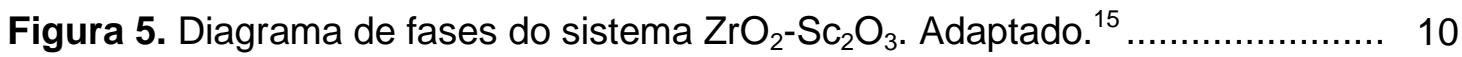

Figura 6. Representação das estruturas cristalinas da zircônia-escândia. (a) Estruturas: monoclínica $(m)$, tetragonal $\left(t^{\prime}\right.$ e $\left.t^{\prime \prime}\right)$ e cúbica $(c)$, adaptado. $^{19,20}$ (b) Estruturas tipo romboédrica $(\beta, \gamma$ e $\delta)$.

Figura 7. Difratogramas de raios $X$ das estruturas cristalinas encontrados no diagrama de fases do sistema zircônia-escândia. Monoclínica $(m)$; tetragonal $(t)$; cúbica $(c)$; romboédrica $(\beta, \gamma$ e $\delta)$

Figura 8. Modelo proposto por Lee e Readay para a formação de aglomerados em precipitados de $\mathrm{ZrO}_{2}$ lavados com (a) água e (b) etanol. As linhas pontilhadas indicam as ligações de hidrogênio. ${ }^{23}$

Figura 9. Valores selecionados de condutividade iônica total, obtidos a $600{ }^{\circ} \mathrm{C}$, em função do raio iônico do segundo aditivo de algumas composições reportadas na literatura. ${ }^{40}$

Figura 10. Fluxograma das etapas de preparação dos pós de zircônia-escândia pelo método de coprecipitação dos hidróxidos.

Figura 11. Fotografia do sistema utilizado durante as sínteses por coprecipitação de zircônia-escândia contendo aditivos.

Figura 12. Fluxograma das etapas de preparação dos pós de zircônia-escândia contendo aditivos pelo método de coprecipitação dos hidróxidos.

Figura 13. Representação esquemática do sistema utilizado para medidas de calor de adsorção de microdosagem controlada de vapor de água. Adaptado. ${ }^{58}$

Figura 14. Representação esquemática da secção transversal do calorímetro de dissolução à alta temperatura. Adaptado. ${ }^{61}$

Figura 15. Fluxograma das etapas de caracterização do sistema ScSZ.

Figura 16. Mapeamento de raios $X$ de $3.1 S c S Z$. (a) Imagem de elétrons retroespalhados; (b) mapeamento de Sc; (c) mapeamento de Zr. 
Figura 17. Difratogramas de raios $X$ de nanopartículas de $\mathrm{ZrO}_{2} \ldots \ldots \ldots \ldots \ldots \ldots \ldots \ldots . . . . . . . . . .46$

Figura 18. Difratogramas de raios $X$ de nanopartículas de 1.1ScSZ ................... 46

Figura 19. Difratogramas de raios $X$ de nanopartículas de 2.1ScSZ .................. 47

Figura 20. Difratogramas de raios $X$ de nanopartículas de 3.1ScSZ ................... 48

Figura 21. Difratogramas de raios $X$ de nanopartículas de $4.2 S c S Z$.................... 48

Figura 22. Difratogramas de raios $X$ de nanopartículas de 6.2ScSZ ................... 49

Figura 23. Difratogramas de raios $X$ de nanopartículas de 8.4ScSZ ................... 49

Figura 24. Difratogramas de raios $X$ de nanopartículas de 10.6ScSZ ................ 50

Figura 25. Difratogramas de raios $X$ de nanopartículas de 11.6ScSZ ................. 51

Figura 26. Difratogramas de raios $X$ de nanopartículas de 12.9ScSZ ................ 51

Figura 27. Difratogramas de raios $X$ de nanopartículas de 13.6ScSZ ................. 52

Figura 28. Difratogramas de raios $X$ de nanopartículas de 14.3ScSZ .................. 52

Figura 29. Difratogramas de raios $X$ de nanopartículas de $19.3 \mathrm{ScSZ}$.................. 53

Figura 30. Parâmetro de rede das soluções sólidas de ScSZ em função da

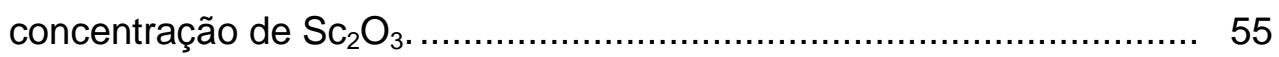

Figura 31. Tamanho médio de cristalito de ScSZ em função do teor de $\mathrm{Sc}_{2} \mathrm{O}_{3} \ldots \ldots .55$

Figura 32. Micrografias dos pós de (a) 4.2ScSZ e (b) 10.6ScSZ calcinados a $500{ }^{\circ} \mathrm{C}$ por $2 \mathrm{~h}$ obtidas por microscópio eletrônico de transmissão. ...... 56

Figura 33. Curvas de microcalorimetria de adsorção de água obtidas para as nanopartículas de ScSZ com estruturas monoclínica, tetragonal e cúbica. (a) Isoterma de cobertura de água em função da pressão relativa. (b) Entalpia de adsorção em função da cobertura de água......

Figura 34. Valores de energia de superfície em função da concentração de $\mathrm{Sc}_{2} \mathrm{O}_{3}$ para cinco polimorfos do sistema zircônia-escândia.

Figura 35. Entalpia de dissolução em função da concentração de $\mathrm{Sc}_{2} \mathrm{O}_{3}$ para cinco polimorfos do sistema zircônia-escândia.

Figura 36. Diagrama de fases de tamanho de partícula-composição para o sistema zircônia-escândia. Amorfo $(A)$, monoclínica $(m)$, tetragonal $(t)$, cúbica $(c)$, romboédrica $(\beta$ e $\gamma)$

Figura 37. Curvas TG e DTA, obtidas sob atmosfera dinâmica de ar sintético com razão de aquecimento de $10{ }^{\circ} \mathrm{C} / \mathrm{min}$, do precursor de 10Sc1DySZ sintetizado por coprecipitação.

Figura 38. Espectros de infravermelho por refletância difusa dos pós precursores de 10Sc1DySZ e 10Sc1NbSZ sintetizados por coprecipitação de hidróxidos. 
Figura 39. Curvas de DSC, obtidas sob atmosfera dinâmica de $\mathrm{N}_{2}$ com razão de aquecimento de $10{ }^{\circ} \mathrm{C} / \mathrm{min}$, dos precursores 10Sc1DySZ e $10 S c 1 \mathrm{NbSZ}$ sintetizados por via úmida.

Figura 40. Difratogramas de raios $X$ de 10Sc1DySZ sintetizado antes e após ser submetido à análise termogravimétrica a 500 e $550{ }^{\circ} \mathrm{C}$ e resfriado à temperatura ambiente.

Figura 41. Difratogramas de raios $X$ dos pós de zircônia-escândia comercial, como recebido, e sintetizados por coprecipitação contendo diferentes teores de óxido de disprósio após calcinação a $500{ }^{\circ} \mathrm{C}$ por $2 \mathrm{~h}$.

Figura 42. Espectro de FTIR do pó calcinado de 10Sc1DySZ sintetizado por coprecipitação e de 10ScSZ comercial.

Figura 43. Micrografias obtidas por microscópio eletrônico de transmissão dos pós calcinados de (a e b) 10Sc1DySZ e (c e d) 10Sc1 NbSZ.

Figura 44. Retração linear e derivada da retração linear dos compactos de (a) 10Sc1DySZ e (b) 10Sc1NbSZ.

Figura 45. Curvas de densidade relativa em função da temperatura para o (a) 10Sc1NbSZ e (b) 10Sc1DySZ obtidas a partir de dilatometria

Figura 46. Difratogramas de raios $X$ de amostras de (a) 10Sc1DySZ e (b) $10 \mathrm{Sc} 1 \mathrm{NbSZ}$ sinterizadas a 1500 e $1550^{\circ} \mathrm{C}$ por $10 \mathrm{~h}$.

Figura 47. Difratogramas de raios $X$ de amostras de $10 S c S Z$ contendo diferentes teores molares de $\mathrm{Dy}_{2} \mathrm{O}_{3}$ sinterizadas a $1450{ }^{\circ} \mathrm{C}$ por tempo de patamar nulo na faixa de $2 \theta$ entre (a) 20 e $80^{\circ}$ e (b) 49 e $53^{\circ}$.

Figura 48. Difratogramas de raios $X$ de amostras de $10 \mathrm{ScSZ}$ contendo diferentes teores molares de $\mathrm{Nb}_{2} \mathrm{O}_{5}$ sinterizadas a $1450{ }^{\circ} \mathrm{C}$ por tempo de patamar nulo na faixa de $2 \theta$ entre (a) 20 e $80^{\circ}$ e (b) 49 e $53^{\circ}$.

Figura 49. Difratogramas de raios $X$ em alta temperatura obtidos durante aquecimento e resfriamento, de amostras sinterizadas a $1450{ }^{\circ} \mathrm{C}$ por 0 h. (a) $10 \mathrm{ScSZ}$ comercial e (b) $10 \mathrm{ScSZ}$ sintetizado por coprecipitação 
Figura 50. Difratogramas de raios $X$ em alta temperatura obtidos durante aquecimento e resfriamento, de amostras sinterizadas a $1450{ }^{\circ} \mathrm{C}$ por 0 h. $10 \mathrm{ScSZ}$ contendo teores molares de $\mathrm{Dy}_{2} \mathrm{O}_{3}$ : (a) $0,5 \%$; (b) $1 \%$ e (c) $1,5 \%$.

Figura 51. Difratogramas de raios $X$ em alta temperatura obtidos durante aquecimento e resfriamento, de amostras sinterizadas a $1450{ }^{\circ} \mathrm{C}$ por 0 h. $10 \mathrm{ScSZ}$ contendo teores molares de $\mathrm{Nb}_{2} \mathrm{O}_{5}$ : (a) $0,25 \%$; (b) $0,5 \%$ e (c) $1 \%$.

Figura 52. Curvas DTA obtidas em função de ciclos térmicos com razão de aquecimento e resfriamento de $10^{\circ} \mathrm{C} / \mathrm{min}$, sob atmosfera dinâmica de ar sintético, de amostras de (a) 10ScSZ comercial e (b) $10 \mathrm{Sc} 1 \mathrm{DySZ}$ sinterizadas a $1450{ }^{\circ} \mathrm{C}$ por $0 \mathrm{~h}$.

Figura 53. Micrografias da superfície de fratura de amostras de (a) 10Sc1DySZ e (b) $10 \mathrm{Sc} 1 \mathrm{NbSZ}$ sinterizadas a $1450^{\circ} \mathrm{C}$ obtidas por FEG.

Figura 54. Difratogramas de raios $X$ das amostras após sinterização assistida por campo elétrico. (a) Antes e (b) após tratamento térmico a $900{ }^{\circ} \mathrm{C}$ por 5 min. * Reflexão característica da estrutura cristalina da grafita. ... 93

Figura 55. Micrografias de amostras de 10Sc1DySZ sinterizadas por SPS:
(a) $1000{ }^{\circ} \mathrm{C}$ por 4 min (fratura),
(b) $1100{ }^{\circ} \mathrm{C}$ por $4 \mathrm{~min}$,
(c) $1200^{\circ} \mathrm{C}$ por $4 \min e(d) 1300{ }^{\circ} \mathrm{C}$ por $4 \min$

Figura 56. Diagramas de impedância em função da temperatura para uma amostra de 10Sc1DySZ sinterizada a $1300{ }^{\circ} \mathrm{C}$ por $4 \mathrm{~min}$. Os números nos diagramas representam o logaritmo decimal da frequência.

Figura 57. Gráficos de Arrhenius para a condutividade elétrica do (a) grão e (b) contorno de grãos de amostras de 10Sc1DySZ sinterizadas por SPS em diferentes temperaturas.

Figura 58. Gráficos de Arrhenius para a condutividade elétrica total de amostras de 10ScSZ comercial sinterizada pelo método convencional, e contendo aditivos preparadas por coprecipitação e sinterizadas por SPS.

Figura 59. Micrografias, obtidas por microscópio eletrônico de varredura, dos pós de (a) 10ScSZ, (b) $\mathrm{Dy}_{2} \mathrm{O}_{3}$ e (c) $\mathrm{Nb}_{2} \mathrm{O}_{5}$. 
Figura 60. Difratogramas de raios $X$ do pó de zircônia-escândia $(10 \% \mathrm{~mol})$ como recebido (superior) e 10ScSZ na fase romboédrica $\beta$ de acordo com a ficha PDF 51-1604 (inferior)

Figura 61. Difratogramas de raios $\mathrm{X}$ do pó de $\mathrm{Dy}_{2} \mathrm{O}_{3}$ como recebido (superior), e do óxido de disprósio de acordo com a ficha PDF 22-612 (inferior). .. 101

Figura 62. Difratogramas de raios $\mathrm{X}$ do pó de $\mathrm{Nb}_{2} \mathrm{O}_{5}$ como recebido (superior) e do óxido de nióbio (V) de acordo com a ficha PDF 37-1468 (inferior). .. 102

Figura 63. Difratogramas de raios $X$ das amostras de $10 \mathrm{ScSZ}$ contendo (a) $1 \%$ e (b) 1,5 e $2 \%$ em mol de $\mathrm{Dy}_{2} \mathrm{O}_{3}$

Figura 64. Difratogramas de raios $X$ de uma amostra de 10Sc1DySZ sinterizada a $1550{ }^{\circ} \mathrm{C}$ por $10 \mathrm{~h}$ antes e após desbaste de $50 \mu \mathrm{m}$.

Figura 65. Difratogramas de raios $X$ das amostras de $10 \mathrm{ScSZ}$ contendo (a) 0,25 e $0,5 \%$ e (b) $1 \%$ em mol de $\mathrm{Nb}_{2} \mathrm{O}_{5}$.

Figura 66. Micrografias obtidas por microscópio eletrônico de varredura de amostras de $10 \mathrm{ScSZ}$ (a) sem aditivos e sinterizada a $1550^{\circ} \mathrm{C}$ por 10 $\mathrm{h}$ e sinterizadas a $1500{ }^{\circ} \mathrm{C}$ por $5 \mathrm{~h}$ contendo diferentes teores molares de $\mathrm{Dy}_{2} \mathrm{O}_{3}:$ (b) $1,5 \%$, (c) $1,5 \%$ e (d) $2 \%$

Figura 67. Micrografias obtidas por microscópio eletrônico de varredura de amostras de $10 \mathrm{ScSZ}$ sinterizadas a $1500{ }^{\circ} \mathrm{C}$ por $5 \mathrm{~h}$ contendo diferentes teores molares de $\mathrm{Nb}_{2} \mathrm{O}_{5}$ : (a) $0,25 \%$, (b) $0,5 \%$ e (c) $1 \%$. 109

Figura 68. Gráfico de Arrhenius para a condutividade elétrica total de amostras de $10 \mathrm{ScSZ}$, sem aditivo sinterizada a $1550^{\circ} \mathrm{C}$ por $10 \mathrm{~h}$, e contendo 1 e $2 \%$ em mol de $\mathrm{Dy}_{2} \mathrm{O}_{3}$ sinterizadas a $1500{ }^{\circ} \mathrm{C}$ por $5 \mathrm{~h}$.

Figura 69. Gráfico de Arrhenius para a condutividade elétrica total de amostras de $10 \mathrm{ScSZ}$ contendo $2 \%$ em mol de $\mathrm{Dy}_{2} \mathrm{O}_{3}$ sinterizadas em diferentes condições.

Figura 70. Gráfico de Arrhenius para a condutividade elétrica total de amostras de $10 \mathrm{ScSZ}$, sem aditivo sinterizada a $1550^{\circ} \mathrm{C}$ por $10 \mathrm{~h}$, e contendo 0,$25 ; 0,5$ e $1 \%$ em mol de $\mathrm{Nb}_{2} \mathrm{O}_{5}$ sinterizadas a $1500{ }^{\circ} \mathrm{C}$ por $2 \mathrm{~h}$.

Figura 71. Valores de condutividade elétrica total normalizada em função do tempo após envelhecimento térmico a $600{ }^{\circ} \mathrm{C}$ para amostras de $10 \mathrm{Sc} 0.5 \mathrm{NbSZ}$ sinterizadas a $1500^{\circ} \mathrm{C}$ por $5 \mathrm{~h}$.

Figura 72. Difratogramas de raios $X$ de amostras de $10 \mathrm{Sc} 0.5 \mathrm{NbSZ}$ submetidas à $600{ }^{\circ} \mathrm{C}$ por várias horas. (a) 0 a $10 \mathrm{~h}$; (b) 20 a $100 \mathrm{~h}$ 


\section{Lista de Tabelas}

Tabela I. Principais características dos elementos estudados. ............................... 4

Tabela II. Características das estruturas do sistema zircônia-escândia. ..................... 12

Tabela III. Materiais de partida utilizados nas sínteses. ........................................... 23

Tabela IV. Teores molares dos aditivos estudados para cada método de síntese. ...... 24

Tabela V. Concentração de escândia, em porcentagem molar, e composição nominal, de amostras de yScSz, determinadas por microanálise por sonda eletrônica.

Tabela VI. Parâmetros de rede de yScSZ, com tamanho médio de partículas inferiores a $10 \mathrm{~nm}$, obtidos usando a ficha PDF 51-1603 da fase tetragonal.

Tabela VII. Valores experimentais encontrados para as amostras de $y \mathrm{ScSZ}$

Tabela VIII. Tamanho médio de partículas $(d)$, área superficial específica $(A S)$ e entalpia de dissolução ( $\left.\Delta H_{\mathrm{DS} \text {, nano }}\right)$ das transições de fase $c-\beta$ e $c-\gamma$ usadas para cálculo das energias de superfície das amostras com estrutura romboédrica.

Tabela IX. Ciclo termoquímico usado para correção dos calores de dissolução obtidos experimentalmente.

Tabela $\mathbf{X}$. Porcentagens em massa de carbono, hidrogênio e nitrogênio nos pós precursores de 10ScSZ contendo aditivos sintetizados por coprecipitação de hidróxidos.

Tabela XI. Valores de densidade relativa $\left(\rho_{R}\right)$ encontrados para amostras de 10Sc1DySZ e 10Sc1 NbSZ preparadas por coprecipitação, calcinadas a $500^{\circ} \mathrm{C}$ por $2 \mathrm{~h}$ e sinterizadas em diferentes temperaturas $(\mathrm{T})$ e tempos de patamar ( $\mathrm{t}$ ).

Tabela XII. Valores de densidade relativa $\left(\rho_{R}\right)$, tamanho médio de grãos $(G)$ e estruturas cristalinas encontradas para amostras de 10ScSZ contendo $1 \%$ em mol de aditivo preparadas por coprecipitação e consolidadas pela técnica de sinterização assistida por campo elétrico em diferentes condições de temperatura (T) e tempo de patamar (t) a $65 \mathrm{MPa}$.

Tabela XIII. Valores de densidade relativa $\left(\rho_{R}\right)$ e estruturas cristalinas encontradas para amostras de $10 \mathrm{ScSZ}$ contendo diferentes teores molares de $\mathrm{Dy}_{2} \mathrm{O}_{3}$ preparadas por mistura de óxidos e sinterizadas em diferentes temperaturas $(T)$ e tempos de patamar $(\mathrm{t})$.

Tabela XIV. Valores de densidade relativa $\left(\rho_{R}\right)$ e estruturas cristalinas encontradas para amostras de zircônia-escândia contendo diferentes teores molares de $\mathrm{Nb}_{2} \mathrm{O}_{5}$ preparadas por mistura de óxidos e sinterizadas em diferentes temperaturas (T) e tempos de patamar $(\mathrm{t})$. 


\section{Sumário}

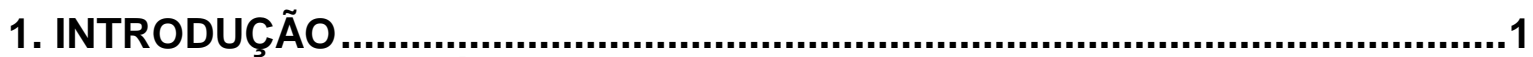

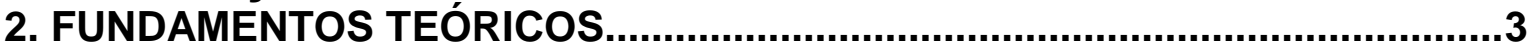

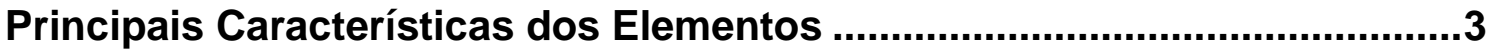

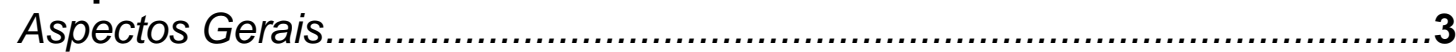

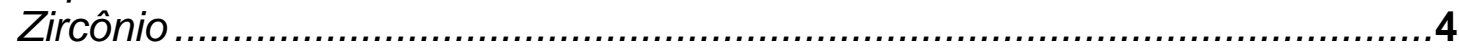

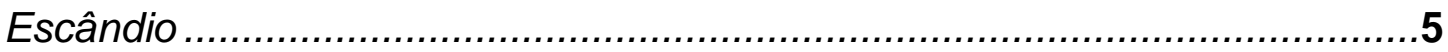

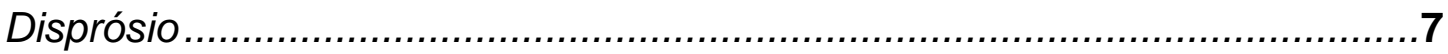

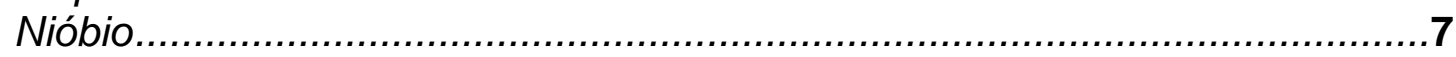

Solução Sólida de Zircônia-Escândia ............................................................8

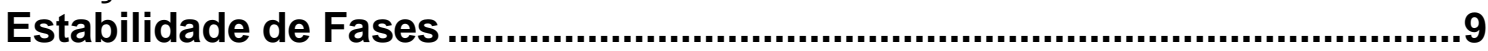

Termodinâmica .......................................................................................14

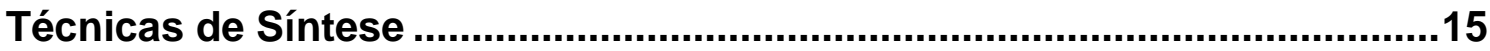

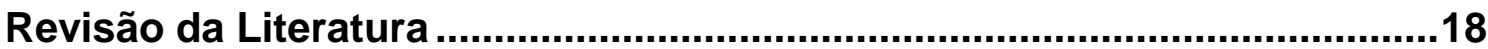

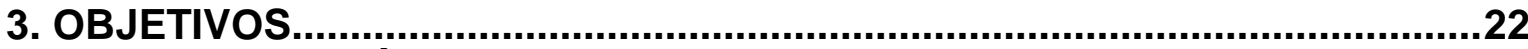

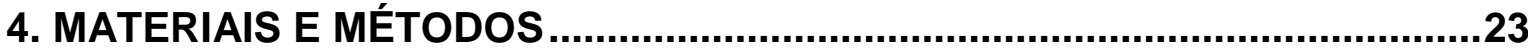

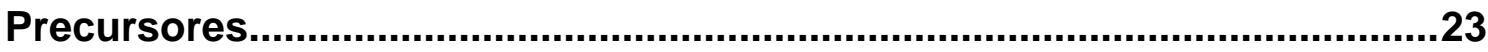

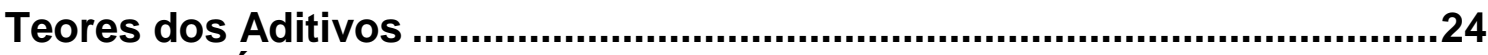

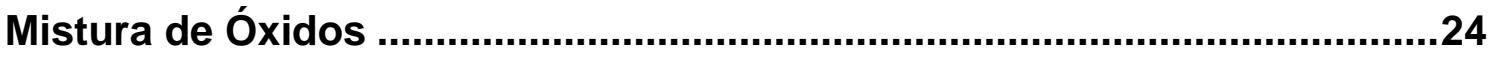

Coprecipitação dos Hidróxidos..............................................................24

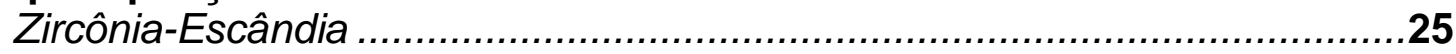

Zircônia-Escândia Contendo Aditivos .......................................................26

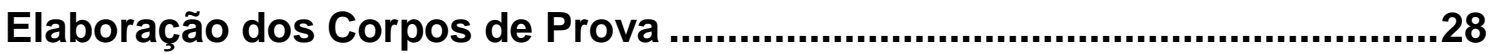

Sinterização Convencional................................................................29

Sinterização Assistida por Campo Elétrico …………………....................29

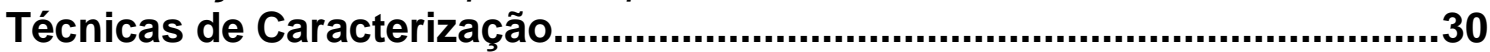

Zircônia-Escândia .............................................................................30

Microanálise por Sonda Eletrônica.....................................................30

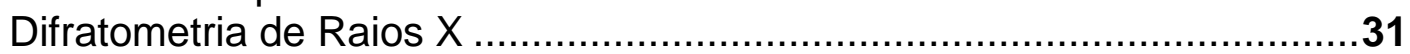

Microscopia Eletrônica de Transmissão ...................................................31

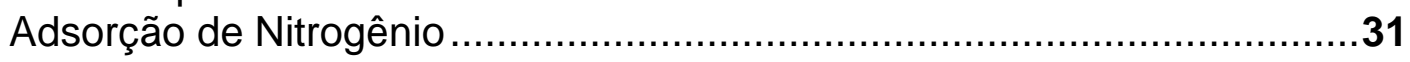

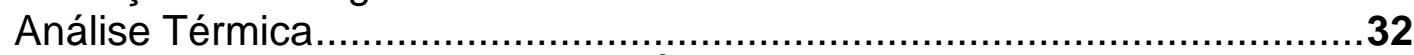

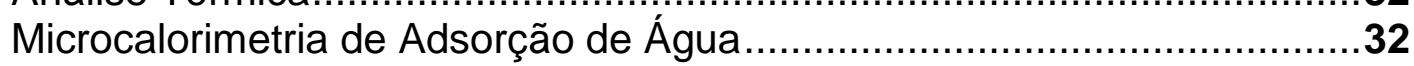

Calorimetria de Dissolução à Alta Temperatura .......................................34

Zircônia-Escândia Contendo Aditivos .......................................................37

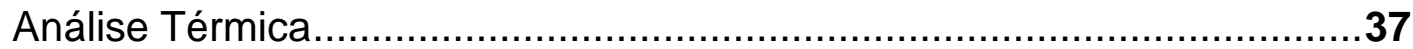

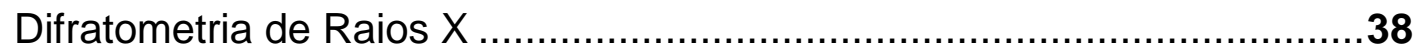

Difratometria de Raios X em Alta Temperatura ......................................39

Análise Elementar (CHN) .............................................................39

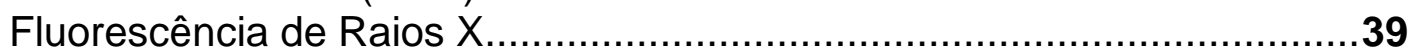

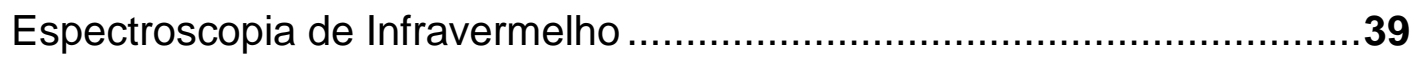

Microscopia Eletrônica de Transmissão ...............................................40

Microscopia Eletrônica de Varredura ……........................................40

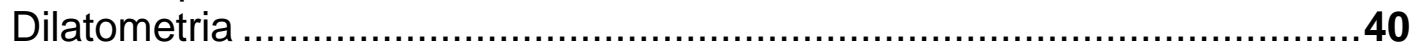

Densidade Aparente.....................................................................

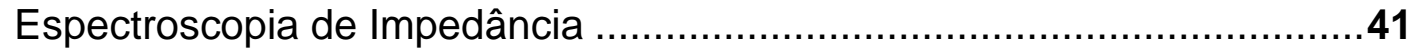

Envelhecimento Térmico ............................................................ 42 


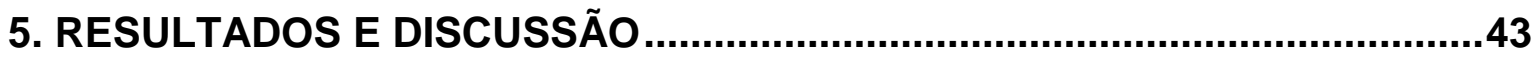

Coprecipitação de Hidróxidos....................................................................43

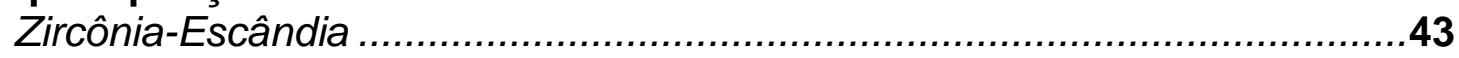

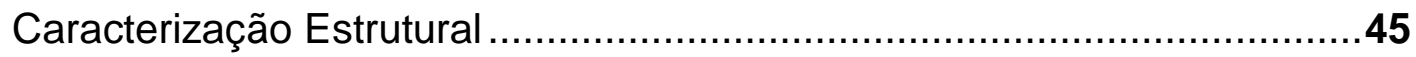

Morfologia das Nanopartículas .......................................................56

Área de Superfície Específica ……………………........................56

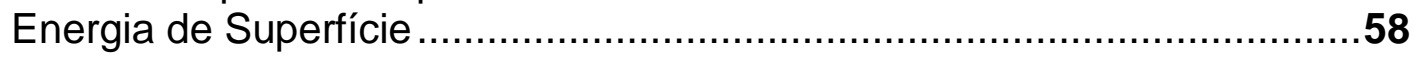

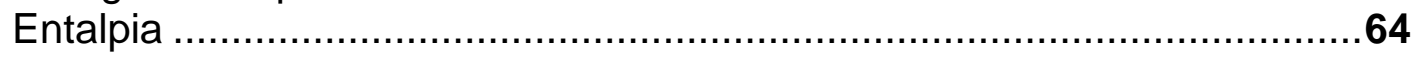

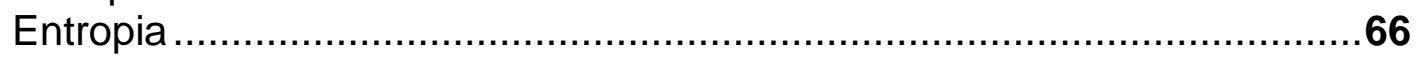

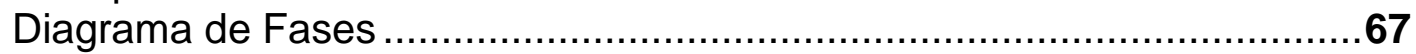

Zircônia-Escândia Contendo Aditivos ......................................................68

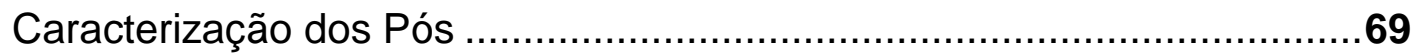

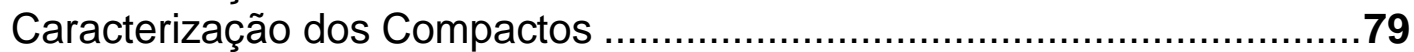

Sinterização Assistida por Campo Elétrico ...............................................91

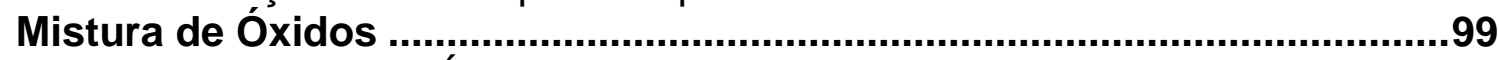

Caracterização dos Óxidos Precursores................................................99

Caracterização dos Compactos ..........................................................102

6. CONCLUSÕES

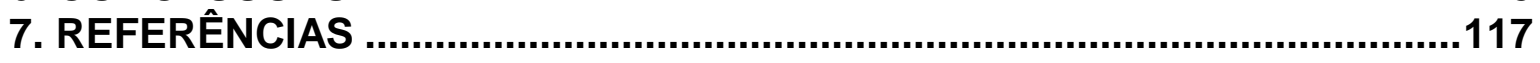

ANEXO 


\section{INTRODUÇÃO}

Condutores de íons oxigênio formam uma classe de materiais funcionais com aplicações tecnológicas em diversas áreas incluindo sensores de espécies químicas, membranas permeáveis ao oxigênio e células a combustível para produção de energia. ${ }^{1}$

Para essas aplicações uma de suas propriedades mais importantes é a condutividade elétrica, que é a soma da condutividade dos íons (cátions e ânions) e elétrons (elétrons e buracos eletrônicos). Idealmente um eletrólito sólido é um condutor de uma única espécie química e um isolante eletrônico. Microscopicamente, isso significa que a concentração de defeitos iônicos deve ser muito superior a de defeitos eletrônicos. Do ponto de vista macroscópico, a condutividade elétrica é influenciada por fatores como pureza dos materiais, parâmetros de processamento como introdução de aditivos e moagem, e tratamentos térmicos como calcinação, sinterização e envelhecimento, que definem a microestrutura do material sinterizado.

Poucos são os óxidos que apresentam altos valores de condutividade para o íon oxigênio. A alta mobilidade iônica, necessária para a obtenção de altos valores de condutividade, só é encontrada em óxidos com estruturas cristalinas específicas. As principais são: ${ }^{1}$ estrutura cúbica de faces centradas tipo fluorita, estrutura tipo pirocloro, estrutura tipo perovsquita e perovsquita modificada, e estrutura tipo apatita.

Os óxidos de estrutura fluorita são conhecidos há mais tempo e são também os mais estudados condutores de íons oxigênio. A estrutura cristalina consiste de uma rede cúbica de íons oxigênio com centros alternados ocupados por cátions. Os cátions são arranjados em uma estrutura cúbica de face centrada com ânions ocupando posições tetraédricas. Isto resulta em uma estrutura aberta com amplos espaços vazios. ${ }^{1,2}$

De todos os condutores de íons oxigênio conhecidos, a zircônia estabilizada com ítria (YSZ) é o mais estudado e, em geral, sua condutividade iônica é considerada como padrão no estudo de novos materiais. Por isso, é o eletrólito sólido preferido para aplicação em células a combustível de óxido sólido (SOFC) que operam a altas temperaturas na faixa de 900 a $1000{ }^{\circ} \mathrm{C}$. 
Nessas condições, os principais problemas encontrados estão relacionados com a alta taxa de degradação, principalmente do ânodo (geralmente um compósito formado entre $\mathrm{Ni}$ e zircônia estabilizada com ítria), o uso de ligas para interconectores de custo relativamente elevado, e aumento da taxa de corrosão dos componentes da célula. ${ }^{3}$

Tendo isto em conta, é desejável que a temperatura de operação da célula seja reduzida para $700{ }^{\circ} \mathrm{C}$ ou menos, mantendo o compromisso de redução da densidade de potência e aumento da estabilidade em longo prazo. Com o objetivo de manter a densidade de potência similar àquela obtida em temperaturas de operação de 900-1000 ${ }^{\circ} \mathrm{C}$, outros materiais cerâmicos com melhores propriedades eletroquímicas são necessários. Dentre estes, o eletrólito sólido desempenha função fundamental em células a combustível de configuração planar suportadas no eletrólito e, portanto, deve possuir condutividade iônica superior a da zircônia estabilizada com ítria (8\% em mol, 8YSZ). Em princípio, três tipos de eletrólitos sólidos destacam-se como alternativas viáveis: a zircônia estabilizada com escândia (ScSZ), a céria contendo terras raras e perovskitas à base de galato de lantânio. Todos estes materiais têm sido extensivamente estudados nos últimos anos, mas ainda não se chegou a um consenso de melhor opção, porque todos apresentam alguma limitação. A zircônia-escândia apresenta uma composição de fases complexa dependendo do teor de Sc; a céria contendo terras raras está sujeita à redução do $\mathrm{Ce}^{4+}$ para $\mathrm{Ce}^{3+}$ em atmosferas redutoras com consequente aumento da condução eletrônica; e o galato de lantânio contendo substituições parciais de estrôncio e magnésio, apresenta fases secundárias precipitadas ao longo dos contornos de grão, que podem comprometer o comportamento elétrico a longo prazo., ${ }^{4,5}$

Do ponto de vista de produção em larga escala (industrial) a zircônia-escândia é a mais interessante, porque suas propriedades químicas e termomecânicas são similares as da zircônia estabilizada com ítria e as interações interfaciais com materiais de eletrodos (ânodo e cátodo) podem ser consideradas como já investigadas. O custo do eletrólito sólido é também esperado que seja reduzido nos próximos anos devido ao aumento da demanda. Assim, neste trabalho o material escolhido para estudo foi a zircônia estabilizada com escândia. 


\section{FUNDAMENTOS TEÓRICOS}

Neste capítulo serão descritas algumas das principais características dos elementos: $\mathrm{Zr}$, Sc, Dy e $\mathrm{Nb}$, bem como, as estruturas cristalinas desses elementos na forma dos principais óxidos. Serão discutidos importantes aspectos da solução sólida de ScSZ, principalmente, em relação à estabilidade de fases. Também será feita uma abordagem termodinâmica da estabilidade de fases em nanocristais, de alguns aspectos importantes sobre técnicas de síntese utilizadas nesse trabalho e uma breve apresentação dos trabalhos mais relevantes sobre o sistema zircônia-escândia.

\section{Principais Características dos Elementos}

Nessa seção será feita uma sucinta abordagem das principais características e aplicações dos elementos estudados, seguida por uma breve apresentação das estruturas cristalinas dos óxidos de cada elemento.

\section{Aspectos Gerais}

A Tabela I sumariza as principais características de cada elemento estudado. Esses elementos são encontrados em posições próximas na tabela periódica, o que indica que apresentam características semelhantes. Embora o Sc possua número atômico ( $Z$ ) inferior ao $Z r$ e, portanto, um menor tamanho, os raios iônicos de $\mathrm{Zr}^{4+}$ e Sc${ }^{3+}$, com número de coordenação 8, são similares. Também há uma grande semelhança no valores de eletronegatividade de $\mathrm{Zr}$ e Sc. A massa atômica $(A)$ do $\mathrm{Zr}$ é bem próxima do $\mathrm{Nb}$. O estado de oxidação mais importante, ou seja, mais abundante e estável, é mostrado na Tabela I para cada elemento.

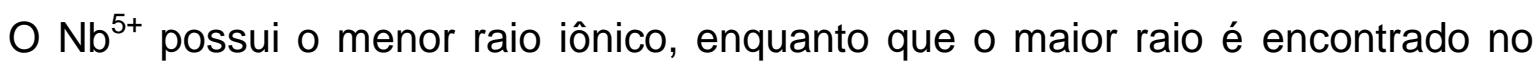
$\mathrm{Dy}^{3+}$. 
Tabela I. Principais características dos elementos estudados.

\begin{tabular}{ccccccc}
\hline Elementos & $\boldsymbol{Z}$ & $\boldsymbol{A}(\mathbf{u})$ & $\begin{array}{c}\text { Configuração } \\
\text { Eletrônica }\end{array}$ & $\begin{array}{c}\text { Estado de } \\
\text { Oxidação* }\end{array}$ & $\begin{array}{c}\text { Raio lônico } \\
(\mathbf{\AA})^{* *} 6\end{array}$ & Eletronegatividade $^{6}$ \\
\hline $\mathrm{Zr}$ & 40 & 91,22 & {$[\mathrm{Kr}] 4 d^{2} 5 s^{2}$} & $4+$ & 0,84 & 1,33 \\
$\mathrm{Sc}$ & 21 & 44,96 & {$[\mathrm{Ar}] 3 d^{1} 4 s^{2}$} & $3+$ & 0,87 & 1,36 \\
$\mathrm{Dy}$ & 66 & 162,50 & {$[\mathrm{Xe}] 4 f^{10} 6 s^{2}$} & $3+$ & 1,03 & 1,22 \\
$\mathrm{Nb}$ & 41 & 92,91 & {$[\mathrm{Kr}] 4 d^{3} 5 s^{2}$} & $5+$ & 0,74 & 1,6 \\
\hline
\end{tabular}

*Estado de oxidação mais comum.

**Raio do íon com número de coordenação 8.

Zircônio

$\mathrm{O} Z \mathrm{r}$ é um metal duro, resistente à corrosão e utilizado principalmente no revestimento de reatores nucleares devido a sua capacidade de absorver nêutrons. $\mathrm{O} \mathrm{ZrO}_{2}$, também conhecido como zircônia, é um dos materiais cerâmicos mais estudados. Possui aplicações em refratários, próteses, sensores eletroquímicos e eletrólitos sólidos. ${ }^{7}$

$\mathrm{O} \mathrm{ZrO}_{2}$ possui três formas polimórficas, à pressão ambiente: cúbica, tetragonal e monoclínica. A estrutura monoclínica é a forma encontrada na natureza. $\mathrm{O}$ aumento da temperatura para $1170{ }^{\circ} \mathrm{C}$ promove a formação da fase tetragonal, a qual se transforma em cúbica por volta de $2350^{\circ} \mathrm{C}$ e permanece estável até a fusão a $2680^{\circ} \mathrm{C} .{ }^{8}$

A adição de óxidos pode promover a formação de solução sólida do tipo substitucional, onde íons $\mathrm{Zr}^{4+}$ são parcialmente substituídos por cátions di- ou trivalentes. Devido à diferença de valência entre $\mathrm{Zr}^{4+}$ e os cátions aditivos $\mathrm{M}^{2+}$ ou $\mathrm{M}^{3+}$ são formados defeitos complementares para manter a condição de neutralidade elétrica da estrutura. $O$ processo conhecido como estabilização da fase cúbica na zircônia ocorre quando há formação da estrutura cúbica tipo fluorita à temperatura ambiente. A estabilização total ou parcial (mistura de fases cúbica com outras formas polimórficas) depende das características e teor do aditivo. 
Duas representações da estrutura cristalina cúbica tipo fluorita com grupo espacial $F m 3 m$ são apresentadas na Figura 1. Na Figura 1a, cada átomo de oxigênio está no vértice de um cubo simples com um átomo de $Z r$ no centro, formando estruturas preenchidas e vazias. Assim, cada átomo de $\mathrm{Zr}$ está circundado por oito átomos de oxigênio, e cada átomo de oxigênio está circundado por 4 átomos de Zr. Dessa forma, a cela unitária pode ser representada por um cubo formado por 4 cubos menores (em destaque) contendo átomos de $\mathrm{Zr}$ no centro, como mostrado na Figura $1 \mathrm{~b}$.
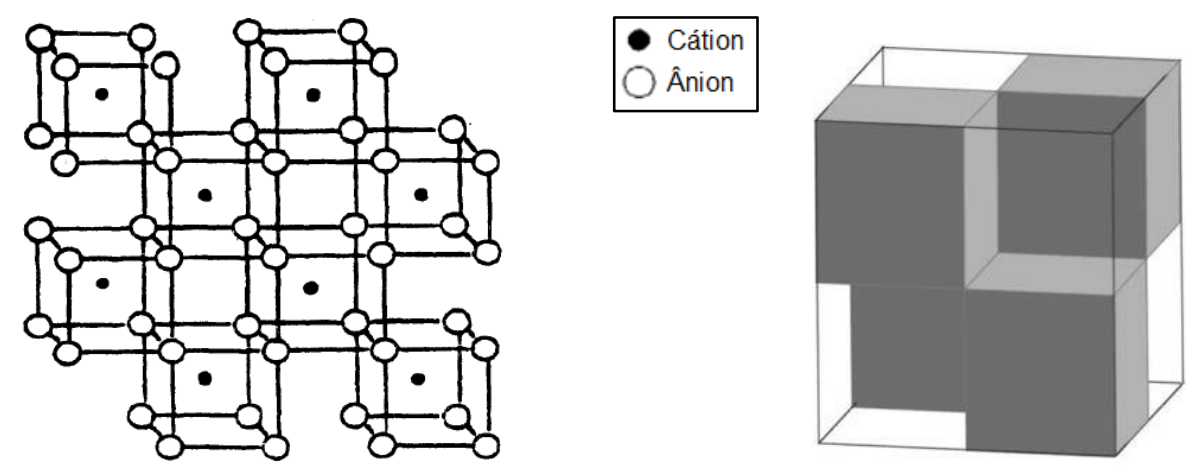

Figura 1. Representações esquemáticas da estrutura cúbica tipo fluorita por meio de (a) esferas e (b) cubos.

\section{Escândio}

Dentre os óxidos utilizados como aditivos ao $\mathrm{ZrO}_{2}, 0 \quad \mathrm{Sc}_{2} \mathrm{O}_{3}$ tem se destacado. $\mathrm{O}$ pequeno tamanho de íons $\mathrm{Sc}^{3+}$ possibilita reagir quimicamente com elementos como: Al, Mg e Zr.

Esse elemento possui poucas aplicações industriais. A principal é na forma de óxido para a produção de lâmpadas de alta luminosidade. O Sc na forma metálica é utilizado na indústria aeroespacial devido ao seu ponto de fusão $\left(1541{ }^{\circ} \mathrm{C}\right)$, muito superior ao do alumínio $\left(660^{\circ} \mathrm{C}\right)$, e a sua baixa densidade $\left(2,98 \mathrm{~g} / \mathrm{cm}^{3}\right)$. 
Apesar de poucas aplicações, o Sc não é um elemento raro, sendo mais abundante que o $\mathrm{Pb}, \mathrm{Hg}, \mathrm{Au}, \mathrm{Ag}$, e até mesmo, $\mathrm{Co}$, o qual é muito utilizado em ligas metálicas. Embora o Sc e o $\mathrm{Y}$ não pertençam ao grupo dos lantanídeos, são chamados de terras raras devido à ocorrência nas mesmas fontes. Devido às características químicas semelhantes, e a maior concentração nos minérios de terras raras, ${ }^{7} \mathrm{O} Y$ possui maior número de aplicações industriais. Isso faz com que o $\mathrm{Y}$ tenha preço muito inferior ao Sc (cerca de 100 vezes menor), embora apresentem proximidade em termos de abundância em massa na crosta terrestre.

Os números de publicações e citações, dos últimos 20 anos, registrados na Web of Science referentes ao $\mathrm{Sc}_{2} \mathrm{O}_{3}$ têm aumentado significativamente como pode ser observado na Figura 2. A maior parte desses trabalhos é referente aos estudos de soluções sólidas de ScSZ para aplicação como eletrólito sólido em SOFC. Dessa forma, com o crescente interesse pelo $\mathrm{Sc}_{2} \mathrm{O}_{3}$, há uma grande tendência em aumentar a produção com a consequente diminuição do preço.
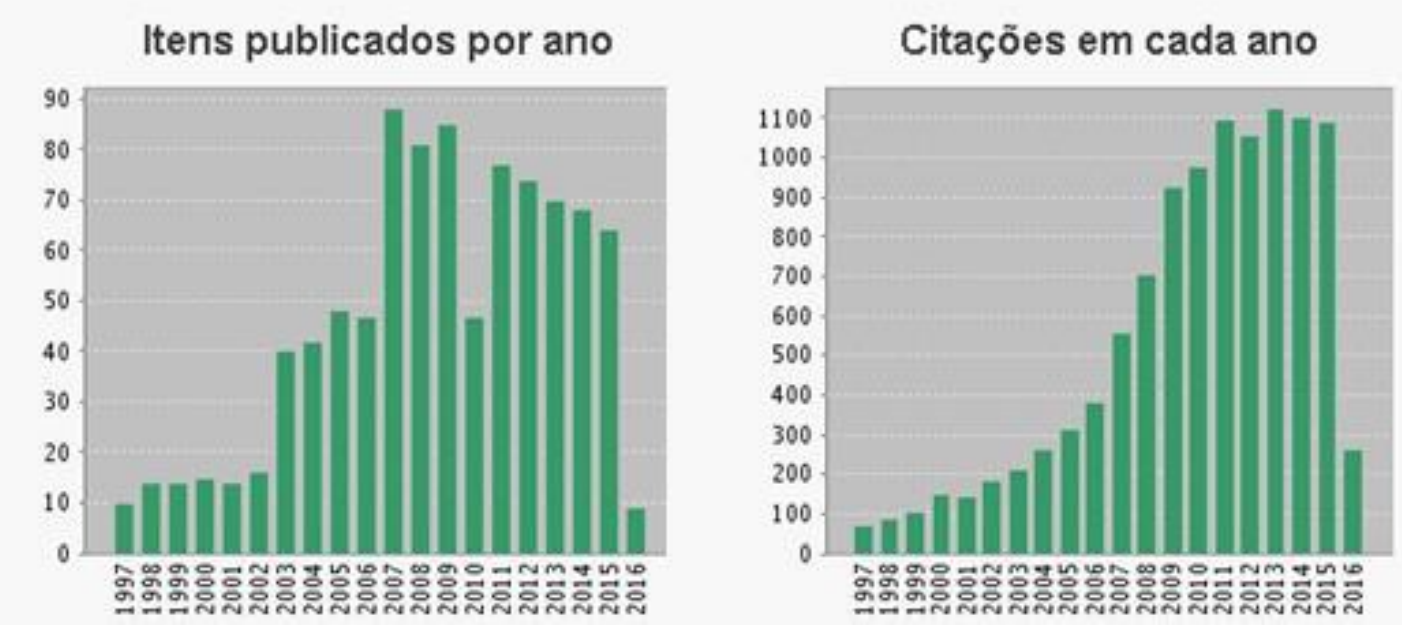

Figura 2. Publicações e citações referentes à escândia registrados na Web of Science nos últimos 20 anos.

$\mathrm{O} \mathrm{Sc}_{2} \mathrm{O}_{3}$ possui estrutura cúbica tipo $\mathrm{C}$ característica de óxidos terras raras. 
Disprósio

O Dy é um elemento terra rara pertencente à família dos lantanídeos. Devido as suas propriedades eletrônicas e magnéticas, esse elemento é utilizado em dispositivos de armazenamento de dados, magnéticos e lasers. Assim como os elementos lantanídeos, o Dy é trivalente em compostos iônicos. ${ }^{7}$

Os óxidos de Sc e Dy possuem estrutura cúbica tipo C com grupo espacial la-3. A representação da estrutura é mostrada na Figura 3. O cátion trivalente é coordenado por 6 átomos de oxigênio formando um cubo distorcido. Essa estrutura forma um arranjo similar à estrutura cúbica fluorita (Figura 1a), onde há formas preenchidas e adjacentes vazias. A cela unitária é formada pode 32 cátions e 48 íons oxigênio. Os parâmetros de rede do $\mathrm{Sc}_{2} \mathrm{O}_{3}$ e $\mathrm{Dy}_{2} \mathrm{O}_{3}$ são iguais a 9,810 e 10,672 , respectivamente. $^{7}$

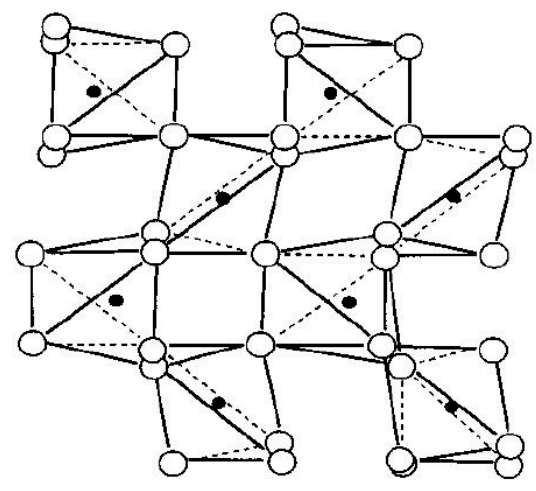

Figura 3. Representação esquemática da estrutura cúbica tipo C.

Nióbio

O $\mathrm{Nb}$ é um elemento de transição de grande interesse nas indústrias de alta tecnologia, especialmente nos setores aeroespacial, devido à formação de superligas metálicas, e de eletroeletrônicos, em que são amplamente utilizados como microcapacitores. ${ }^{9}$ O Brasil possui mais de $90 \%$ das reservas mundiais exploráveis de $\mathrm{Nb}$, sendo, portanto, o maior produtor e exportador do elemento. 
Os estados de oxidação mais comuns do elemento na forma de óxido são $2+, 4+$ e $5+. \mathrm{O} \mathrm{Nb}_{2} \mathrm{O}_{5}$, também conhecido como pentóxido de nióbio, possui relativamente baixa temperatura de fusão $1512{ }^{\circ} \mathrm{C}$ e várias formas polimórficas, sendo todas constituídas por octaedros de $\mathrm{Nb}$ e identificadas por diversos prefixos. ${ }^{7}$ A forma mais comum, mostrada na Figura 4, é a monoclínica $\mathrm{H}-\mathrm{Nb}_{2} \mathrm{O}_{5}$, a qual apresenta uma estrutura complexa com uma cela unitária contendo 28 átomos de $\mathrm{Nb}$ e 70 de $\mathrm{O}$, onde 27 átomos de $\mathrm{Nb}$ possuem número de coordenação 6 e apenas 1 átomo de $\mathrm{Nb}$ é coordenado por 4 átomos de $\mathrm{O}$ formando um tetraedro.

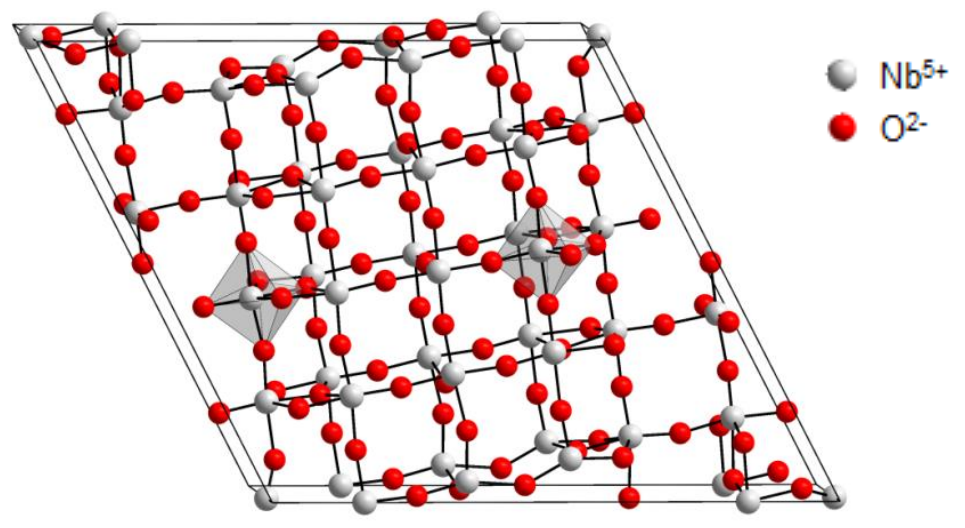

Figura 4. Representação esquemática da estrutura monoclínica do $\mathrm{Nb}_{2} \mathrm{O}_{5}$.

\section{Solução Sólida de Zircônia-Escândia}

A adição de $\mathrm{Sc}_{2} \mathrm{O}_{3}$ à rede cristalina do $\mathrm{ZrO}_{2}$ resulta na substituição de $\mathrm{Sc}^{3+}$ por $Z \mathrm{Zr}^{4+}$ na subrede catiônica e promove a geração de vacâncias de oxigênio devido à compensação de carga. A reação de formação de defeitos na solução sólida entre $\mathrm{Sc}_{2} \mathrm{O}_{3}$ e $\mathrm{ZrO}_{2}$ pode ser representada pela notação de Kroeger e Vink: ${ }^{10}$

$$
\mathrm{Sc}_{2} \mathrm{O}_{3} \stackrel{\mathrm{ZrO}_{2}}{\longrightarrow} 2 \mathrm{Sc}^{\prime} \mathrm{Zr}+3 \mathrm{O}_{\circ}{ }^{\times}+\mathrm{V}_{\circ} \cdot
$$

Dessa forma, uma vacância de oxigênio duplamente ionizada $\left(V_{0}{ }^{*}\right)$ é formada para cada dois átomos de Sc incorporados na rede (Sc'zr). O símbolo $\mathrm{O}_{0}{ }^{x}$ representa um átomo de $\mathrm{O}$ na sua posição normal da rede cristalina. 
As vacâncias provenientes da reação de substituição possibilitam a mobilidade de íons $\mathrm{O}^{2-}$ e, portanto, aumentam a condutividade iônica do $\mathrm{ZrO}_{2}$. A condutividade elétrica $\left(\sigma_{T}\right)$ é a soma das condutividades de íons $\left(\sigma_{i}\right)$ e elétrons $\left(\sigma_{\mathrm{e}^{-}}\right)$:

$$
\sigma_{T}=\sigma_{i}+\sigma_{e^{-}}
$$

Para aplicações que requerem compostos condutores iônicos é desejável que a condução eletrônica seja desprezível $\left(\sigma_{i} \gg>>\sigma_{\mathrm{e}^{-}}\right)$, uma vez que pode haver recombinação de íons e elétrons em materiais que possuem condução mista (iônica e eletrônica) provocando a diminuição da condutividade iônica. ${ }^{2}$ No caso de eletrólito sólido, a condução eletrônica pode provocar curto circuito na célula a combustível de óxido sólido.

$\mathrm{Em}$ materiais à base de $\mathrm{ZrO}_{2}$, a maior condutividade iônica é encontrada no sistema zircônia-escândia. ${ }^{11,12}$ O ScSZ apresenta alta condutividade para íons oxigênio, cerca de 2,5 vezes superior à condutividade da zircônia-ítria, baixa condutividade eletrônica e alta estabilidade química, quando comparada aos demais condutores de íons $\mathrm{O}^{2-11,12}$ Devido a essas características, este sistema passou a ser estudado para aplicações que requerem alta condutividade iônica, sendo um candidato para aplicação como eletrólito sólido em SOFC para operação a temperaturas inferiores àquelas da zircônia-ítria, em um faixa denominada intermediária entre aproximadamente 600 e $800{ }^{\circ} \mathrm{C} .{ }^{11,12}$

\section{Estabilidade de Fases}

O diagrama de fases do sistema zircônia-escândia é mostrado na Figura 5. Para teores inferiores a $9 \%$ em mol de escândia, o ScSZ apresenta composição de fases: cúbica $(c)$, tetragonal $(t)$ e monoclínica $(m){ }^{12,13}$ Além disso, dois tipos de fase tetragonal metaestáveis, denominadas $t^{\prime}$ e $t^{\prime \prime}$, também foram reportadas. ${ }^{14-16}$ Três fases tipo romboédrica com estequiometrias diferentes: $\mathrm{Sc}_{2} \mathrm{Zr}_{7} \mathrm{O}_{17}(\beta)$, $\mathrm{Sc}_{2} \mathrm{Zr}_{5} \mathrm{O}_{13}(\gamma)$ e $\mathrm{Sc}_{4} \mathrm{Zr}_{3} \mathrm{O}_{12}(\delta)$ são observadas para teores molares superiores a $9 \%{ }^{17}$ 
Concentrações entre 9 e $13 \%$ em mol de $\mathrm{Sc}_{2} \mathrm{O}_{3}$ promovem a estabilização da estrutura romboédrica $(\beta)$ à temperatura ambiente. ${ }^{12,13}$ No entanto, na faixa de temperatura entre 500 e $600^{\circ} \mathrm{C}$ ocorre a transição de fase reversível romboédrica $\leftrightarrow$ cúbica. $^{12}$

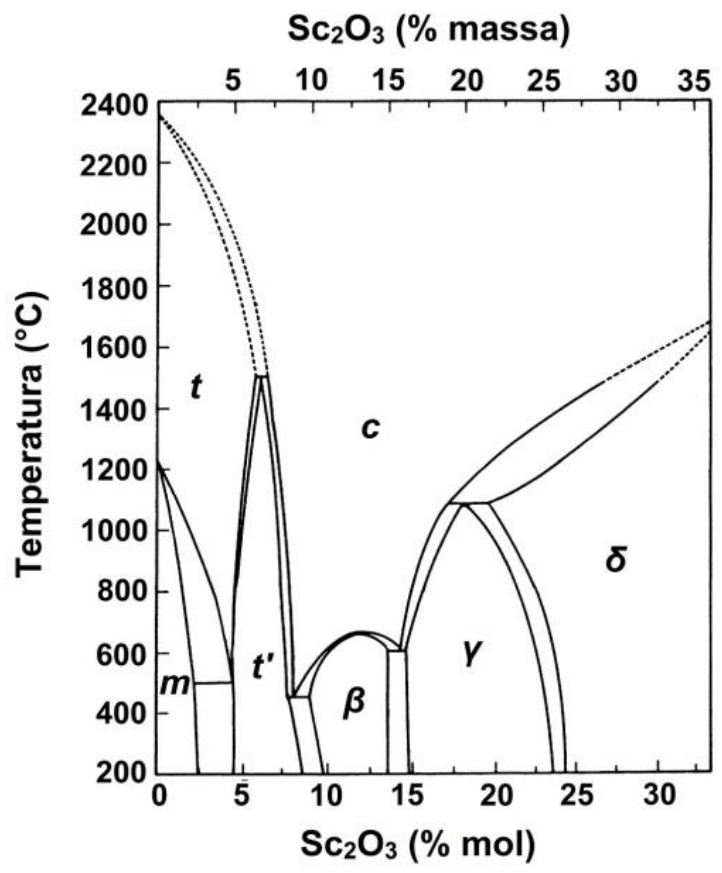

Figura 5. Diagrama de fases do sistema $\mathrm{ZrO}_{2}-\mathrm{Sc}_{2} \mathrm{O}_{3}$. Adaptado. ${ }^{17}$

Dessa forma, devido à estabilização da fase de maior condutividade iônica em alta temperatura $\left(>600^{\circ} \mathrm{C}\right.$ ), a maior parte dos trabalhos realizados com zircônia-escândia tem se concentrado em um faixa de composição molar de $\mathrm{Sc}_{2} \mathrm{O}_{3}$ entre aproximadamente 7 e $13 \%$, onde as fases cúbica, tetragonal e romboédrica $(\beta)$ são encontradas. ${ }^{5,16,18-20}$ As fases de maior condutividade são a tetragonal $(t)$ e a cúbica, sendo que os maiores valores foram encontrados para teores de $9 \%$. Entretanto, para composições iguais ou inferiores a 9\%, a taxa de degradação térmica é severa devido à formação da estrutura $t^{\prime}$ na matriz cúbica em condições de operação da SOFC. ${ }^{18,19}$

As estruturas cristalinas da zircônia-escândia são mostradas na Figura 6 . Os círculos cheios e vazios representam os cátions $\left(\mathrm{Zr}^{4+} \mathrm{e} \mathrm{Sc}^{3+}\right)$ e ânions $\left(\mathrm{O}^{2-}\right)$, respectivamente. Nessa representação, os cátions se encontram nos vértices da estrutura. As setas apresentadas em algumas estruturas na Figura 6a indicam o deslocamento de íons oxigênio de suas posições normais na estrutura cristalina. 
A estrutura tetragonal $t$ é semelhante à tetragonal metaestável $t$ ', sendo que não há deslocamento de íons no polimorfo $t$. A fase $t^{\prime \prime}$ é formada por uma subrede cúbica de cátions e uma subrede descentralizada de íons oxigênio ao longo do eixo $c$, o que origina uma simetria tetragonal com grupo espacial $P 4_{2} / n m c^{21,22}$ As principais características estruturais estão sumarizadas na Tabela II.

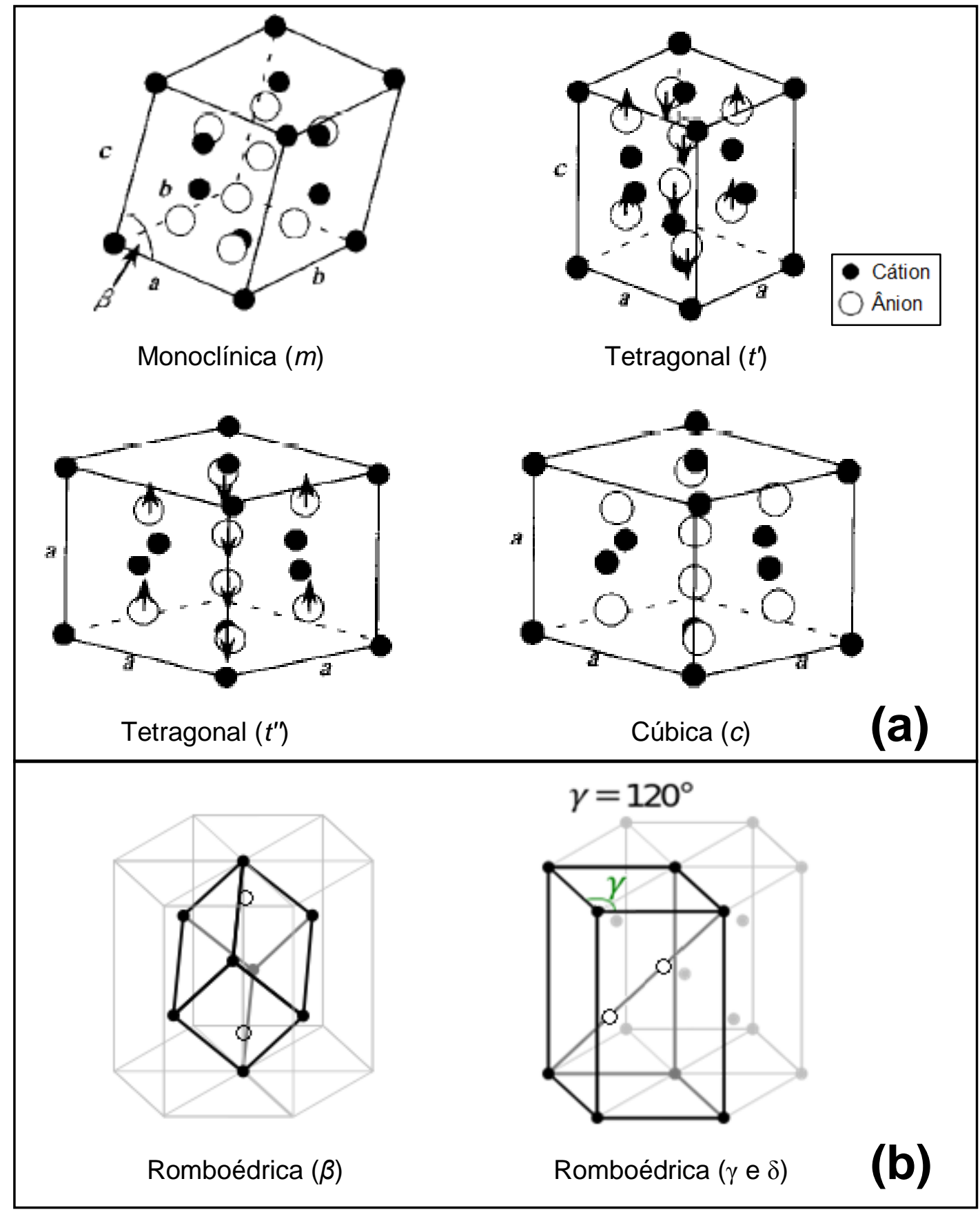

Figura 6. Representação das estruturas cristalinas da zircônia-escândia. (a) Estruturas: monoclínica $(m)$, tetragonal $\left(t^{\prime}\right.$ e $\left.t^{\prime \prime}\right)$ e cúbica $(c)$, adaptado. $^{21,22}$ (b) Estruturas tipo romboédrica $(\beta, \gamma$ e $\delta)$. 
A estrutura romboédrica pode ser representada por duas maneiras, como mostrado na Figura 6b. Na primeira configuração, a qual dá origem ao nome da estrutura, há um romboedro dentro de um hexágono com parâmetros de rede $a=b=c$ e ângulos interaxiais idênticos diferentes de $90^{\circ}$. A fase $\beta$ é mais bem representada por essa forma geométrica. Por outro lado, a partir da representação por meio de hexágono, é possível perceber que as fases $\gamma$ e $\delta$ possuem parâmetros de rede $a=b \neq c$ e ângulos $\alpha=\beta=90^{\circ}$ e $\gamma=120^{\circ}$. Em ambos os casos, dois íons de oxigênio estão localizados no interior da estrutura. A diferença entre as fases $\gamma$ e $\delta$ está no parâmetro de rede $c$, de acordo com a Tabela II.

Tabela II. Características das estruturas do sistema zircônia-escândia.

\begin{tabular}{cccc}
\hline Estrutura & Grupo Espacial & Parâmetros de Rede & Ângulos Interaxiais \\
\hline Monoclínica $(m)$ & $P 2_{1} / c$ & $a<b<c$ & $\alpha=\gamma=90^{\circ}, \beta \approx 99^{\circ}$ \\
Tetragonal $(t)$ & $P 4_{2} / \mathrm{nmc}$ & $a=b<c$ & $\alpha=\beta=\gamma=90^{\circ}$ \\
Tetragonal $\left(t^{\prime}\right)$ & $\mathrm{P} 4_{2} / \mathrm{nmc}$ & $a=b<c$ & $\alpha=\beta=\gamma=90^{\circ}$ \\
Tetragonal $\left(t^{\prime \prime}\right)$ & $\mathrm{P} 4_{2} / \mathrm{nmc}$ & $a=b=c$ & $\alpha=\beta=\gamma=90^{\circ}$ \\
Cúbica $(c)$ & $F m 3 m$ & $a=b=c$ & $\alpha=\beta=\gamma=90^{\circ}$ \\
Romboédrica $(\beta)$ & $R 3$ & $a=b=c$ & $\alpha=\beta=\gamma \neq 90^{\circ}$ \\
Romboédrica $(\gamma)$ & $R 3$ & $a=b<c$ & $\alpha=\beta=90^{\circ}, \gamma=120^{\circ}$ \\
Romboédrica $(\delta)$ & $R 3$ & $a=b>c$ & $\alpha=\beta=90^{\circ}, \gamma=120^{\circ}$ \\
\hline
\end{tabular}

Os difratogramas de raios $X$ das estruturas cristalinas (monoclínica, tetragonal, cúbica, romboédrica $\beta, \gamma$ e $\delta$ ) com suas respectivas fichas PDF são mostrados na Figura 7. É interessante notar que há grande semelhança entre os difratogramas de raios $X$ das fases cúbica e tetragonal no intervalo de $2 \theta$ entre 20 e $80^{\circ}$. As principais diferenças entre os polimorfos de ScSZ estão na faixa de 30 e $50^{\circ}$, onde é possível perceber picos de difração bem característicos de cada estrutura cristalina. 


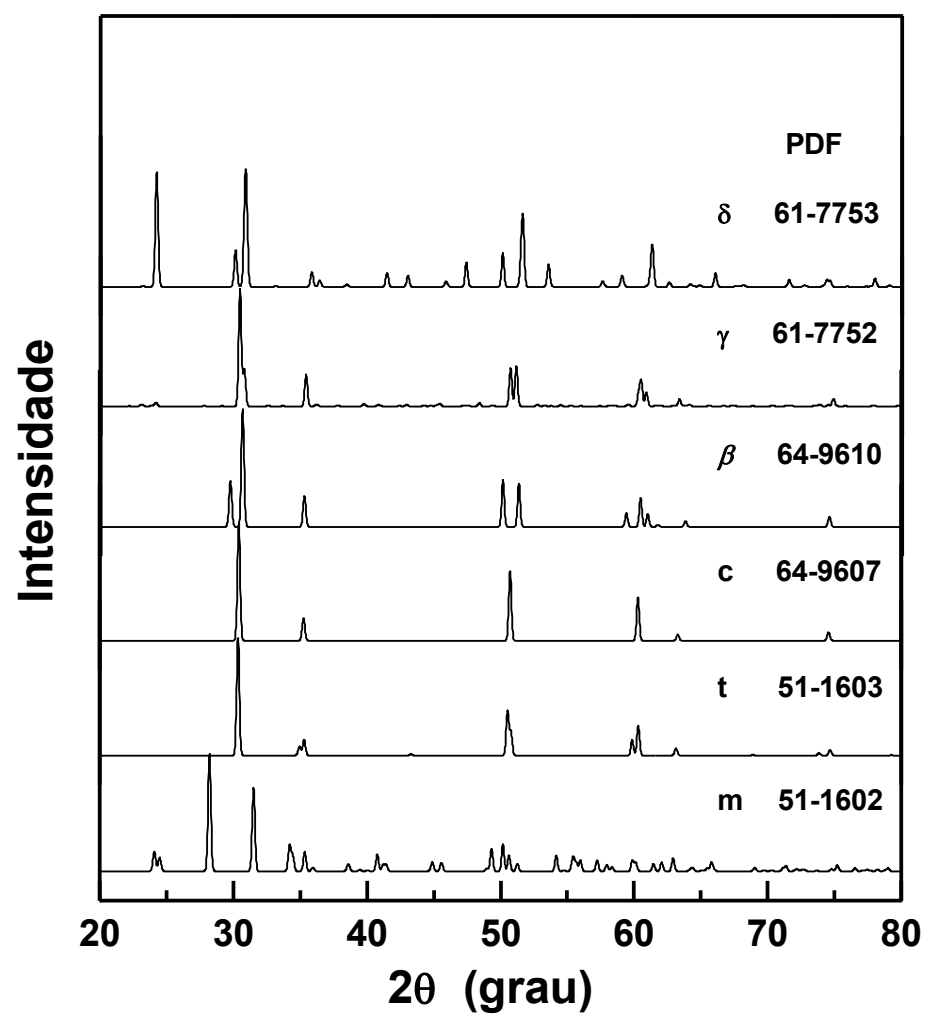

Figura 7. Difratogramas de raios $X$ das estruturas cristalinas encontrados no diagrama de fases do sistema zircônia-escândia. Monoclínica $(m)$; tetragonal $(t)$; cúbica $(c)$; romboédrica $(\beta, \gamma$ e $\delta)$.

De acordo com a literatura, existem dois principais fatores que podem promover a estabilização da fase cúbica nas soluções sólidas de ScSZ. A adição de um segundo aditivo vem sendo investigada, onde diversos autores demonstraram que é possível obter um material cúbico monofásico à temperatura ambiente. O segundo fator é a diminuição do tamanho de cristalito para escala denominada nanométrica $(<100 \mathrm{~nm}$ ). Esse efeito pode ser explicado com base nas propriedades termodinâmicas de nanocristais. 


\section{Termodinâmica}

A estabilidade de fases de nanomateriais pode ser avaliada com base na termodinâmica. Devido à alta reatividade de nanopartículas, o termo de energia de superfície em excesso pode ser adicionado à equação da energia livre de Gibbs para amplas áreas de superfície específica, de acordo com a seguinte equação:

$$
G=H-T S+A S . E S
$$

onde $H$ é a entalpia molar em $\mathrm{kJ} / \mathrm{mol}$, $T$ é a temperatura absoluta em $\mathrm{K}$, $S$ é a entropia molar em $\mathrm{J} / \mathrm{mol}$, AS é a área de superfície específica em $\mathrm{m}^{2} / \mathrm{mol}$ e ES é a energia de superfície em $\mathrm{J} / \mathrm{m}^{2}$. No equilíbrio químico entre duas formas polimórficas ( $\alpha$ e $\beta$ ), a energia de Gibbs é igual a zero. Assumindo que não há mudança na área superficial do sistema durante a transformação de fase $\alpha-\beta$, a Eq.(3) pode ser escrita como:

$$
\Delta G_{\alpha \rightarrow \beta}=\Delta H_{\alpha \rightarrow \beta}-T \Delta S_{\alpha \rightarrow \beta}+A S \cdot E S_{\alpha \rightarrow \beta}=0
$$

e rearranjada em função da área de superfície, como segue:

$$
A S=\frac{\left(H_{\beta}-H_{\alpha}\right)-T\left(S_{\beta}-S_{\alpha}\right)}{\left(E S_{\alpha}-E S_{\beta}\right)}
$$

Essa relação mostra a dependência de uma área de superfície crítica (e, portanto, tamanho de partícula crítico), que prediz que a transformação de fase não é apenas dependente da entalpia e entropia, mas depende também da energia de superfície. Portanto, com a finalidade de encontrar uma relação entre o tamanho de partícula e as propriedades termodinâmicas, considerando partículas esferoidais, o termo de área superficial específica (em $\mathrm{m}^{2} / \mathrm{mol}$ ) em função do tamanho de partícula (d) pode ser expresso pela Eq.(6): 


$$
A S=\frac{6 \cdot M}{d . \rho}
$$

onde $M$ é a massa molar em $\mathrm{g} / \mathrm{mol}$ e $\rho$ é a densidade em $\mathrm{g} / \mathrm{cm}^{3}$. Finalmente, as Eq.(5) e Eq.(6) podem ser combinadas e rearranjadas:

$$
d=\frac{6 \cdot M\left(E S_{\alpha}-E S_{\beta}\right)}{\rho\left[\left(H_{\beta}-H_{\alpha}\right)-T\left(S_{\beta}-S_{\alpha}\right)\right]}
$$

Portanto, a estabilidade de fases pode ser avaliada em função do tamanho de partícula. Conforme demonstrado, para essa finalidade é necessário obter dados acurados de energia de superfície, entalpia e entropia dos polimorfos envolvidos na transição de fase.

Contudo, as propriedades dos materiais cerâmicos são fortemente dependentes da composição química e de características físicas e estruturais, as quais são determinadas pelos métodos de preparação.

\section{Técnicas de Síntese}

Diversos métodos de síntese têm sido empregados na preparação de materiais à base de zircônia, como: técnicas de estado sólido, ${ }^{23,24}$ de via úmida ${ }^{24-28}$ e fase gasosa. ${ }^{29,30}$

A principal técnica que envolve reações no estado sólido consiste basicamente na reação entre os reagentes na forma de óxidos e/ou carbonatos. Esses precursores são misturados e submetidos a tratamentos térmicos em diferentes temperaturas até a obtenção do material desejado podendo haver etapas intermediárias de moagem. A principal vantagem desse tipo de síntese é a sua simplicidade aliada a baixo custo, podendo ser utilizada para preparações tanto em escala laboratorial quanto industrial. As principais desvantagens desta técnica são a necessidade de tratamentos térmicos a elevadas temperaturas e tempos prolongados, baixo grau de homogeneidade química e possibilidade de contaminação durante a moagem do material. ${ }^{31}$ 
Algumas características dos materiais precursores devem ser consideradas nas reações de estado sólido. Um fator importante é a estrutura dos materiais precursores. As estruturas cristalinas dos precursores devem ser compatíveis entre si para a obtenção dos pós cerâmicos a temperaturas mais baixas. ${ }^{10}$ As condições de reação, como temperatura e tempo de patamar são aspectos fundamentais para a obtenção de homogeneidade química e estrutural. Reações no estado sólido normalmente não ocorrem a baixas temperaturas. Deve-se, na medida do possível, adotar a melhor relação tempo-temperatura.

As técnicas de via úmida e fase gasosa são chamadas de não convencionais e apresentam vantagens como a obtenção de materiais de alta pureza com elevada homogeneidade química e pequeno tamanho de partículas quando comparadas com o método convencional.

A síntese por coprecipitação de hidróxidos é uma técnica de solução que apresenta baixo custo para produção de óxidos quando comparada a outros métodos, como sol-gel e processos de fase gasosa. Uma das principais vantagens dessa técnica é a produção de pós ultrafinos de alta pureza e elevada homogeneidade química. Contudo, a principal desvantagem é a formação de aglomerados fortes durante a síntese ou nas etapas de secagem e calcinação. ${ }^{26}$

A presença de aglomerados pode prejudicar o processo de densificação de pós cerâmicos. Contudo, alguns aglomerados são mais prejudiciais que outros. Aglomerados fracos, os quais se desintegram durante a conformação dos compactos, de forma geral, não comprometem a densificação. De outro modo, aglomerados fortes não são quebrados durante a compactação e podem impedir a densificação desses materiais mesmo em temperaturas superiores a $1600^{\circ} \mathrm{C} .^{32}$

Alguns autores demonstraram que é possível controlar a aglomeração em pós à base de zircônia na etapa de secagem através de lavagens dos precipitados com álcool. ${ }^{25-27}$ A ilustração do modelo proposto por Lee e Readay ${ }^{25}$ para as interações que ocorrem durante lavagens com (a) água e (b) álcool são mostradas na Figura 8. De acordo com o modelo, as ligações de hidrogênio entre as moléculas de água e grupos hidroxila ligados à superfície das partículas originadas durante a precipitação, promovem a formação de ligações entre partículas adjacentes. 
A lavagem com etanol possibilita a substituição das moléculas de água por etanol, que por sua vez, também fazem ligações de hidrogênio com os grupos hidroxila da superfície impedindo a interação entre partículas. Dessa forma, a possibilidade de formação de alguma ligação química entre partículas durante secagem é significativamente reduzida. Portanto, a adição de etanol pode inibir a formação de aglomerados fortes.

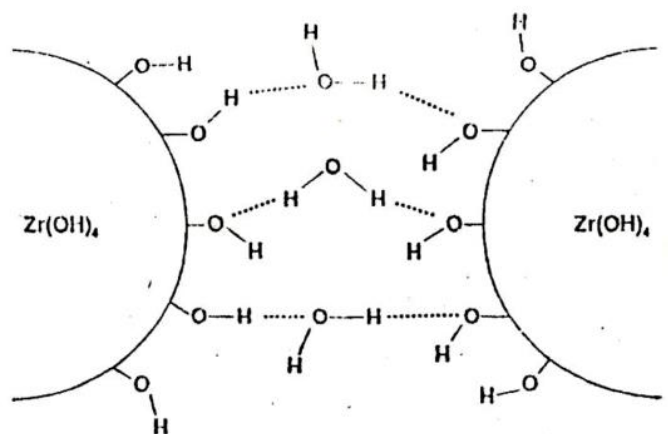

(A)

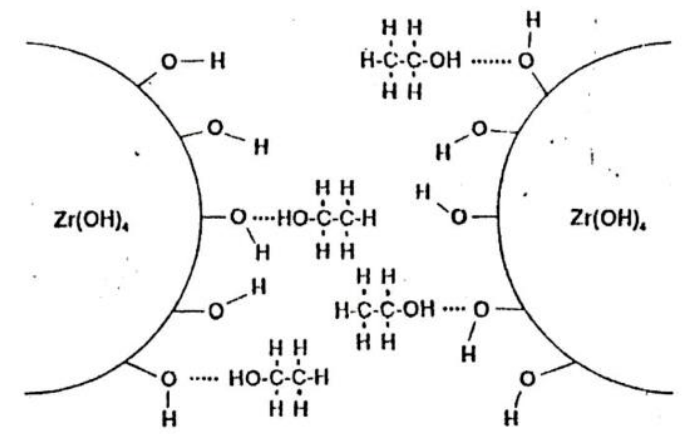

(B)

Figura 8. Modelo proposto por Lee e Readay para a formação de aglomerados em precipitados de $\mathrm{ZrO}_{2}$ lavados com (a) água e (b) etanol. As linhas pontilhadas indicam as ligações de hidrogênio. ${ }^{25}$

De modo geral, o método denominado de coprecipitação de hidróxidos, que corresponde à precipitação simultânea de cátions na forma de hidróxidos, tem apresentado resultados interessantes em relação à obtenção de materiais ultrafinos com boa homogeneidade química. Dessa forma, esse método foi utilizado para a obtenção de zircônia-escândia. Para análise comparativa, amostras contendo aditivos também foram preparadas por mistura de óxidos. 


\section{Revisão da Literatura}

Apesar da estabilidade de fases do sistema zircônia-escândia ter sido bastante estudada, os clássicos diagramas de fases de temperatura e composição não consideram o efeito do tamanho dos cristais na estabilidade estrutural. Recentemente, a estabilidade de fases de materiais à base de zircônia foi investigada com base nas propriedades termodinâmicas de nanopartículas. ${ }^{33,34}$ Foram determinados os diagramas de fases em nanoescala para zircônia-ítria ${ }^{33}$ e zircônia-cálcia. ${ }^{34}$

Alguns autores também demonstraram que há influência do tamanho dos cristais na estabilização da fase cúbica da zircônia-escândia ${ }^{14,15}$. Amostras de $\mathrm{ZrO}_{2}$ contendo 10, 12 e $14 \%$ em mol de $\mathrm{Sc}_{2} \mathrm{O}_{3}$ foram estudas por difratometria de raios X e espectroscopia Raman. Os autores verificaram que a estabilização da fase cúbica à temperatura ambiente ocorre para cristais de tamanho inferior a $25 \mathrm{~nm}$. Acima desse valor, a estrutura cúbica se transforma em romboédrica $\beta$ (10 e 12\%) e $\gamma(14 \%)$. A fase tetragonal $t$ " foi identificada em nanopartículas de $10 \mathrm{ScSZ}$.

Recentemente, foi reportado que a estrutura cúbica em nanofibras de $10 S c S Z$ é estabilizada para tamanho médio de cristalito inferior a $26 \mathrm{~nm}$. Além disso, a diminuição do tamanho de cristalito de 37 para $7 \mathrm{~nm}$ apresentou um aumento maior que 20 vezes da condutividade iônica das nanofibras. ${ }^{35}$

Okamoto e colaboradores, ${ }^{36}$ a partir da sinterização assistida por campo elétrico (Spark Plasma Sintering, SPS), ${ }^{37}$ obtiveram a fase cúbica em amostras densas de $12 \mathrm{ScSZ}$ com tamanho médio de cristalito da ordem de $37 \mathrm{~nm}$ e demonstraram a eliminação da descontinuidade no gráfico de Arrhenius da condutividade elétrica. Posteriormente, Lei e $\mathrm{Zhu}^{38}$ também obtiveram a fase cúbica na zircônia contendo $11 \%$ em mol de escândia em amostras densas com tamanho médio de grãos da ordem de $80 \mathrm{~nm}$.

O processamento pode promover forte influência nas propriedades dos materiais. Além do efeito termodinâmico, a cinética também é um fator importante em termos de estabilidade de fases. Foi demonstrado que a transformação de fase pode ocorrer durante o resfriamento de nanocristais de ScSZ. ${ }^{14}$ 
Dessa forma, de acordo com a literatura, tem sido demonstrada uma forte influência do tamanho das partículas na estabilidade de fases, principalmente em relação à estrutura cúbica, no sistema zircônia-escândia, similar ao efeito causado pela adição de um segundo aditivo.

Com a finalidade de estabilizar a estrutura cúbica na zircônia-escândia e suprimir a transição de fase cúbica-romboédrica, característica do sistema binário para composições molares de $\mathrm{Sc}_{2} \mathrm{O}_{3}$ entre 9,5 e 13\%, ${ }^{5,13}$ a introdução de um segundo aditivo tem sido utilizada com relativa frequência. De maneira geral, a composição mais estudada é a de zircônia contendo $10 \%$ em mol de escândia e $1 \%$ mol do segundo aditivo (representada por $1 \mathrm{M} 10 \mathrm{ScSZ}$ ou $10 \mathrm{Sc} 1 \mathrm{MSZ}$, onde $\mathrm{M}$ = cátion do segundo aditivo). Até o momento, dentre os óxidos que possibilitaram a estabilização da fase cúbica à temperatura ambiente destacam-se: $\mathrm{Al}_{2} \mathrm{O}_{3},{ }^{39}$ $\mathrm{Gd}_{2} \mathrm{O}_{3},{ }^{23} \mathrm{Y}_{2} \mathrm{O}_{3},{ }^{40} \mathrm{Yb}_{2} \mathrm{O}_{3},{ }^{41} \mathrm{CaO},{ }^{42} \mathrm{MgO},{ }^{42} \mathrm{Fe}_{2} \mathrm{O}_{3},{ }^{43} \mathrm{Bi}_{2} \mathrm{O}_{3},{ }^{44} \mathrm{HfO}_{2},{ }^{45} \mathrm{Ga}_{2} \mathrm{O}_{3},{ }^{45}$ $\mathrm{Mn}_{2} \mathrm{O}_{3}{ }^{46} \mathrm{CeO}_{2}{ }^{45} \mathrm{e}$, mais recentemente, $\mathrm{Sm}_{2} \mathrm{O}_{3},{ }^{41} \mathrm{La}_{2} \mathrm{O}_{3}{ }^{47}$ e $\mathrm{Ho}_{2} \mathrm{O}_{3}{ }^{48}$ A principal propriedade avaliada, além da estrutura cristalina, é a condutividade iônica.

A Figura 9 apresenta de modo comparativo, a condutividade iônica total obtida a $600{ }^{\circ} \mathrm{C}$ em função do raio iônico do segundo aditivo de algumas composições reportadas na literatura. ${ }^{41}$ Como pode ser observado, até $\mathrm{o}$ momento, a maior condutividade encontrada em materiais à base de zircônia-escândia é no sistema 10Sc1CeSZ.

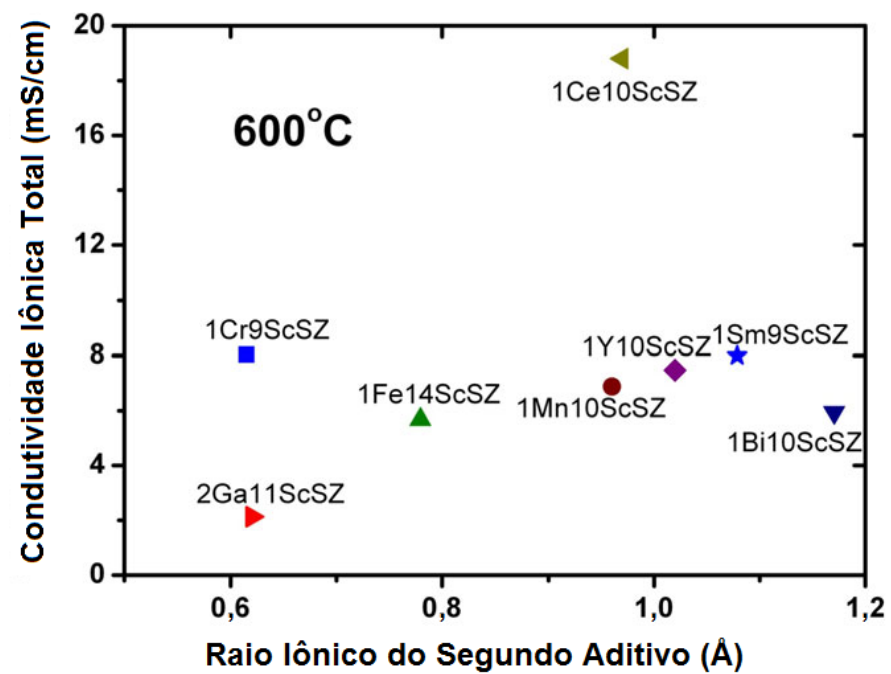

Figura 9. Valores selecionados de condutividade iônica total, obtidos a $600{ }^{\circ} \mathrm{C}$, em função do raio iônico do segundo aditivo de algumas composições reportadas na literatura. Adaptado. ${ }^{41}$ 
Diversos trabalhos reportaram as características do 10 Sc1CeSZ. ${ }^{45,49-52}$. Alguns autores avaliaram as propriedades deste sistema utilizando materiais comerciais. $^{53-55}$ Yarmolenko e colaboradores $^{53}$ analisaram o $10 \mathrm{Sc1CeSZ}$ comercializado pelas empresas, Daiichi Kigenso Kagaku Kogyo (DKKK) e Praxair. Apenas o material produzido pela empresa DKKK apresentou uma composição de fases com pequena quantidade de fase romboédrica $(\beta)$ na matriz cúbica à temperatura ambiente. A menor condutividade iônica encontrada no material produzido pela Praxair foi atribuída à presença de sílica segregada nos contornos de grão. ${ }^{54}$

Grosso e Muccillo ${ }^{55}$ avaliaram o efeito de diferentes métodos de sinterização na estrutura cristalina, na densificação e na condutividade iônica do 10Sc1CeSZ comercializado pela Fuel Cell Materials. A sinterização pelo método convencional, a partir de $1350{ }^{\circ} \mathrm{C}$ em tempo de patamar nulo promoveu a estabilização da estrutura cúbica e a completa densificação (>99\%) do material. No entanto, na faixa de temperatura entre 1150 e $1300{ }^{\circ} \mathrm{C}$ ocorreu a formação de fase secundária $\beta$ na matriz cúbica. Dessa forma, embora o 10Sc1CeSZ apresente estrutura cúbica à temperatura ambiente, foi demonstrado que tratamentos térmicos de sinterização exercem forte influência na sua estrutura cristalina.

A formação da fase secundária romboédrica na zircônia-escândia-céria da Fuel Cell Materials sinterizada em baixas temperaturas pode ser evitada com a sinterização assistida por campo elétrico. ${ }^{56}$ Com este método foram obtidas amostras densas (>95\%), com estrutura cúbica a $1100^{\circ} \mathrm{C}$ em tempo de patamar curto (5 minutos), com tamanho médio de grãos reduzidos em comparação com o processo convencional de sinterização. A espectroscopia Raman mostrou que a estrutura cristalina predominante é cúbica, mas que os compactos sinterizados em diversas temperaturas apresentam também a fase tetragonal $t$.

Omar e colaboradores ${ }^{41}$ estudaram a influência da adição molar de $1 \%$ de óxidos metálicos trivalentes na estrutura e condutividade iônica da zircônia contendo $10 \%$ em mol de escândia (10ScSZ). Os óxidos foram introduzidos, por reações em estado sólido, ao $10 \mathrm{ScSZ}$ comercializado pela empresa japonesa Semi Chemical Corporation. A adição dos óxidos de Sc, Yb e Y promoveu a estabilização parcial da fase cúbica com baixo teor de fase $\beta$. 
$\mathrm{O} \quad \mathrm{In}_{2} \mathrm{O}_{3}$ não apresentou influência estrutural à temperatura ambiente. Apenas os óxidos de $\mathrm{Gd}$ e $\mathrm{Sm}$ possibilitaram a obtenção de materiais com estrutura cúbica monofásica. Segundo os autores, o efeito do raio do íon aditivo é determinante na condutividade total, a qual aumenta com o aumento do raio até um valor crítico entre 0,95 e 1,0 $\AA$ e então diminui. Valores de condutividade iônica semelhantes ao do $10 \mathrm{Sc} 1 \mathrm{CeSZ}$, a $600^{\circ} \mathrm{C}$ (Figura 9), foram encontrados para as soluções sólidas estudadas com exceção do $10 \mathrm{Sc} 1 \mathrm{SmSZ}$.

Estudos de envelhecimento térmico (aging) realizados a $600{ }^{\circ} \mathrm{C}$ no $10 \mathrm{Sc} 1 \mathrm{YbSZ}^{41}$ demonstraram que a degradação da condutividade após $2000 \mathrm{~h}$ de exposição em atmosferas de ar e redutora chega a 9,1\% e 12,0\%, respectivamente. Para ambas as condições, os autores atribuíram essa diminuição da condutividade à segregação de $\mathrm{Yb}^{3+}$ nos contornos de grão. De outro modo, embora o 10Sc1CeSZ apresente degradação da condutividade de cerca de $6 \%$ somente após $3000 \mathrm{~h}$ em ar, esse efeito é mais severo em atmosfera redutora e chega a $20 \%$ devido à redução do cátion $\mathrm{Ce}^{4+}$ para $\mathrm{Ce}^{3+}{ }^{32}$

Após as primeiras $1000 \mathrm{~h}$, o 10Sc1YbSZ apresentou taxa de degradação de $\sim 1,1 \% / 1000 \mathrm{~h}$ para ambas as atmosferas ${ }^{41}$ Por convenção, para aplicações práticas em SOFC, a degradação da condutividade iônica do eletrólito não pode exceder $0,1 \%$ por $1000 \mathrm{~h}$ em condições de operação da célula. ${ }^{57}$

Para os materiais à base zircônia-escândia, a ausência de degradação da condutividade iônica foi reportada, recentemente, somente em amostras contendo ítria como aditivo. ${ }^{40}$ Os experimentos foram realizados a $850{ }^{\circ} \mathrm{C}$ por $2700 \mathrm{~h}$ em atmosfera de ar.

Dessa forma, embora o mecanismo de estabilização da fase cúbica, em composições ternárias, à base de zircônia-escândia ainda não seja bem conhecido, a adição de diversos óxidos metálicos, principalmente, terras raras pode estabilizar a fase de maior condutividade iônica nesses materiais, com valores de condutividade adequados para aplicações em SOFC. 


\section{OBJETIVOS}

Esse trabalho teve como objetivo o estudo da estabilidade de fases do sistema zircônia-escândia por meio do estudo termodinâmico de nanopartículas, na faixa de 0 a $20 \%$ em mol de $\mathrm{Sc}_{2} \mathrm{O}_{3}$, e pela introdução de um segundo aditivo $\left(\mathrm{Dy}_{2} \mathrm{O}_{3}\right.$ e $\left.\mathrm{Nb}_{2} \mathrm{O}_{5}\right)$ ao $\mathrm{ZrO}_{2}$ contendo $10 \%$ em mol de $\mathrm{Sc}_{2} \mathrm{O}_{3}$.

Dessa forma, os objetivos podem ser subdivididos em:

1. Determinar valores de energia de superfície de nanopartículas de $\mathrm{ZrO}_{2}$ contendo diferentes teores de $\mathrm{Sc}_{2} \mathrm{O}_{3}(0$ a $20 \%$ em mol), sintetizadas por coprecipitação de hidróxidos, por meio das técnicas de microcalorimetria de adsorção de água e calorimetria de dissolução a alta temperatura visando obter o diagrama de fases em nanoescala de tamanho de partícula-composição.

2. Estabelecer e otimizar metodologias adequadas para a produção de cerâmicas densas de zircônia-escândia contendo aditivos $\left(\mathrm{Dy}_{2} \mathrm{O}_{3}\right.$ e $\left.\mathrm{Nb}_{2} \mathrm{O}_{5}\right)$ por meio das técnicas de mistura de óxidos e coprecipitação de hidróxidos, visando obter estabilização da estrutura cristalina cúbica e supressão da transformação de fase cúbica-romboédrica, bem como, investigar o efeito dos aditivos na condutividade iônica da zircônia-escândia. 


\section{MATERIAIS E MÉTODOS}

Neste capítulo serão apresentadas algumas características dos materiais de partida e a descrição do procedimento experimental utilizado nas sínteses por mistura de óxidos e coprecipitação de hidróxidos. As condições experimentais das técnicas de caracterização realizadas também serão reportadas.

\section{Precursores}

Os materiais utilizados nas sínteses estão listados na Tabela III. As composições de $\mathrm{ZrO}_{2}$ contendo $10 \%$ em mol de $\mathrm{Sc}_{2} \mathrm{O}_{3}$ (10ScSZ) e concentrações do segundo aditivo $\left(\mathrm{Dy}_{2} \mathrm{O}_{3}\right.$ e $\left.\mathrm{Nb}_{2} \mathrm{O}_{5}\right)$, que serão referidos como 10ScxDySZ e 10ScxNbSZ (onde $x$ é a concentração molar do óxido aditivo), foram sintetizadas por reações no estado sólido a partir da mistura dos aditivos ao 10ScSZ comercial. O método de coprecipitação de hidróxidos foi utilizado para a preparação de amostras de zircônia contendo diferentes teores de escândia, para o estudo termodinâmico de nanopartículas, e do sistema 10ScSZ contendo aditivos.

Os materiais à base de nióbio, $\mathrm{Nb}_{2} \mathrm{O}_{5}$ e $\mathrm{NH}_{4}\left[\mathrm{NbO}\left(\mathrm{C}_{2} \mathrm{O}_{4}\right)_{2}\left(\mathrm{H}_{2} \mathrm{O}\right)\right] \cdot \mathrm{xH}_{2} \mathrm{O}$, foram cedidos pela Companhia Brasileira de Metalurgia e Mineração (CBMM).

Tabela III. Materiais de partida utilizados nas sínteses.

\begin{tabular}{lccc}
\hline \multicolumn{1}{c}{ Material } & Fórmula & Fabricante & Pureza \\
\hline Óxido de Zircônio & $\mathrm{ZrO}_{2}$ & Tosoh & $99,9 \%$ \\
Óxido de Escândio & $\mathrm{Sc}_{2} \mathrm{O}_{3}$ & Alfa Aesar & $99,9 \%$ \\
Óxido de Disprósio & $\mathrm{Dy}_{2} \mathrm{O}_{3}$ & Alfa Aesar & $99,9 \%$ \\
Óxido de Nióbio & $\mathrm{Nb}_{2} \mathrm{O}_{5}$ & CBMM & $99,99 \%$ \\
Zircônia-Escândia (10\% em mol) & $10 \mathrm{ScSZ}^{2}$ & DKKK & $99,99 \%$ \\
Nitrato de Zirconila Hidratado & $\mathrm{ZrO}\left(\mathrm{NO}_{3}\right)_{2} \cdot \mathrm{xH}_{2} \mathrm{O}$ & Aldrich & $99 \%$ \\
Nitrato de Escândio Hidratado & $\mathrm{Sc}\left(\mathrm{NO}_{3}\right)_{3} \cdot \mathrm{xH}_{2} \mathrm{O}$ & Alfa Aesar & $99,9 \%$ \\
Nitrato de Disprósio Pentahidratado & $\mathrm{Dy}\left(\mathrm{NO}_{3}\right)_{3} \cdot 5 \mathrm{H}_{2} \mathrm{O}$ & Alfa Aesar & $99,9 \%$ \\
Oxalato Amoniacal de Nióbio Hidratado & $\mathrm{NH}_{4}\left[\mathrm{NbO}^{2}\left(\mathrm{C}_{2} \mathrm{O}_{4}\right)_{2}\left(\mathrm{H}_{2} \mathrm{O}\right)\right] \cdot \times \mathrm{H}_{2} \mathrm{O}$ & CBMM & $99,99 \%$ \\
\hline${ }^{*}$ Empresa japonesa Daiichi Kigenso Kagaku Kogyo. & & &
\end{tabular}




\section{Teores dos Aditivos}

Foi avaliado o efeito da adição de diferentes teores dos aditivos ao 10ScSZ. A Tabela IV lista os diferentes teores dos aditivos estudados para cada método de síntese. As porcentagens molares estudadas foram selecionadas com base nos resultados experimentais obtidos por difratometria de raios $X$ à temperatura ambiente.

Tabela IV. Teores molares dos aditivos estudados para cada método de síntese.

\begin{tabular}{ccc}
\hline Síntese & $\mathrm{Dy}_{2} \mathbf{O}_{3}(\%$ em mol) & $\mathbf{N b}_{2} \mathbf{O}_{5}$ (\% em mol) \\
\hline Coprecipitação de Hidróxidos & 0,$5 ; 1,0$ e 1,5 & 0,$25 ; 0,5$ e 1,0 \\
Mistura de Óxidos & 1,$0 ; 1,5$ e 2,0 & 0,$25 ; 0,5$ e 1,0 \\
\hline
\end{tabular}

Para 0 estudo termodinâmico do sistema zircônia-escândia $\left(\mathrm{Sc}_{2} \mathrm{O}_{3}\right)_{y}\left(\mathrm{ZrO}_{2}\right)_{1-y}$, foram sintetizadas, por coprecipitação de hidróxidos, 13 composições na faixa de 0 a $20 \%$ em mol de $\mathrm{Sc}_{2} \mathrm{O}_{3}$. Cada composição será referida como yScSZ, onde $y$ é o teor molar de $\mathrm{Sc}_{2} \mathrm{O}_{3}$.

\section{Mistura de Óxidos}

Os pós precursores foram utilizados como recebidos, sendo apenas mantidos em estufa a $100{ }^{\circ} \mathrm{C}$ para eliminação de água adsorvida na superfície das partículas e pesagem. Quantidades estequiométricas dos óxidos foram pesadas e homogeneizadas em almofariz de ágata por 15 minutos, em meio de álcool isopropílico. A secagem foi feita em estufa a $40^{\circ} \mathrm{C}$ por $1 \mathrm{~h}$.

\section{Coprecipitação dos Hidróxidos}

O método de coprecipitação de hidróxidos foi utilizado para a preparação de amostras de zircônia-escândia, sem aditivos durante o período em que foi realizado estágio de pesquisa no exterior, no Laboratório de Termoquímica de Nanocerâmicas na Universidade da Califórnia - Davis, e contendo aditivos no Laboratório de Eletrocerâmicas do IPEN. 


\section{Zircônia-Escândia}

Para a realização da síntese por coprecipitação, nanopós de ScSZ foram sintetizados pelo método de coprecipitação de hidróxidos. ${ }^{25-27}$ As etapas do processamento são apresentadas no fluxograma na Figura 10.

Inicialmente, foram preparadas as soluções aquosas de nitrato de zirconila e escândio. A concentração de cada elemento foi aferida por gravimetria. Quantidades estequiométricas das soluções foram misturadas e homogeneizadas para preparar uma solução de concentração de cátions igual a $0,5 \mathrm{~mol} / \mathrm{L}$. Essa solução foi adicionada a uma outra contendo $5 \mathrm{~mol} / \mathrm{L}$ em excesso de hidróxido de amônio, onde ocorreu o processo de precipitação simultânea dos cátions. Durante a precipitação manteve-se agitação com um agitador magnético.

O material precipitado foi separado por centrifugação a 2.800 rpm durante 5 minutos e submetido a processos de lavagem e centrifugação, sendo lavado com água deionizada, álcool etílico a 50\% e álcool etílico anidro para remover resíduos de amônio e minimizar o teor de moléculas de água da superfície das partículas. Por fim, os pós foram secos em estufa a $100{ }^{\circ} \mathrm{C}$ por cerca de $50 \mathrm{~h}$, desaglomerados em almofariz de ágata e calcinados em forno tipo caixa em várias condições de temperatura e tempo visando à obtenção de nanopartículas monofásicas com diferentes tamanhos (Tabela - Anexo).

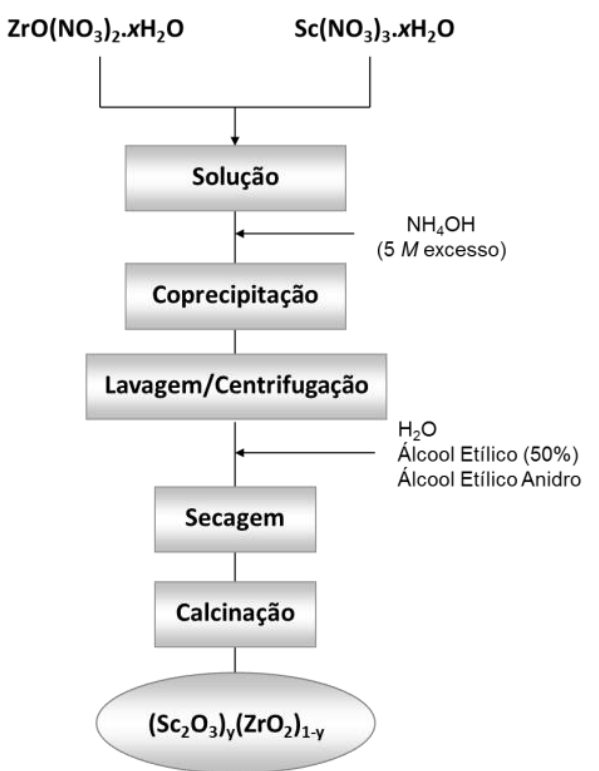

Figura 10. Fluxograma das etapas de preparação dos pós de zircônia-escândia pelo método de coprecipitação dos hidróxidos. 


\section{Zircônia-Escândia Contendo Aditivos}

Soluções estoque dos nitratos e do oxalato amoniacal de nióbio foram preparadas pela dissolução dos sais em água deionizada. A concentração foi determinada por gravimetria. O hidróxido de amônio de grau analítico foi utilizado como agente precipitante.

Inicialmente, foram misturadas as soluções contendo os cátions de interesse para homogeneização. Nessa solução, a concentração total dos cátions foi de 0,1 mol/L. A adição da solução contendo os cátions sobre o agente precipitante foi realizada por meio de uma bureta para garantir um gotejamento controlado e promoveu a formação de um precipitado branco e gelatinoso. Durante a precipitação manteve-se agitação com um agitador magnético (Fisatom 752A) e pH entre 9 e 10, o qual foi controlado pela adição de solução de $\mathrm{NH}_{4} \mathrm{OH}$ e monitorado por um pHmetro (Micronal, modelo B-474). A concentração inicial de $\mathrm{NH}_{4} \mathrm{OH}$ foi de $0,2 \mathrm{~mol} / \mathrm{L}$. A imagem do sistema utilizado para realização das sínteses pelo método de coprecipitação é mostrada na Figura 11.

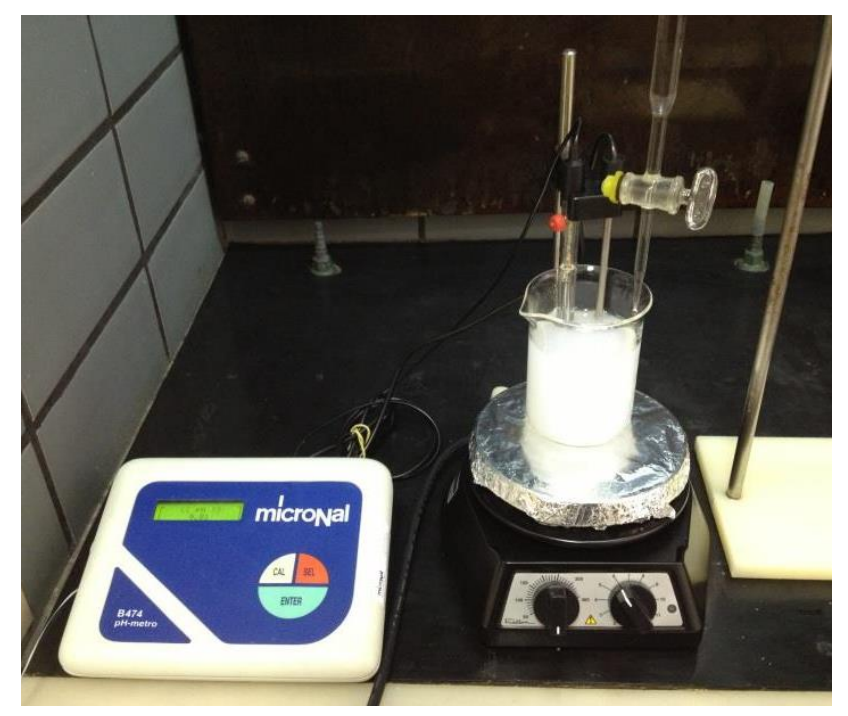

Figura 11. Fotografia do sistema utilizado durante as sínteses por coprecipitação de zircônia-escândia contendo aditivos. 
Durante o processo de precipitação simultânea dos cátions de interesse, o $\mathrm{pH}$ foi mantido entre 9 e $10 \mathrm{com}$ a finalidade de evitar a dissolução dos hidróxidos formados. Assim como o $\mathrm{pH}$, o produto de solubilidade $\left(K_{\mathrm{ps}}\right)$ de cada espécie química também é um fator determinante para esse tipo de síntese. Os hidróxidos de $\mathrm{Zr}$ e Sc apresentam valores de $K_{\mathrm{ps}}$ iguais a $3,5.10^{-63} 58$ e 2,2.10 $0^{-31},{ }^{59}$ respectivamente. Enquanto que o produto de solubilidade do $\mathrm{Dy}(\mathrm{OH})_{3}$ é igual a $1,4.10^{-22}{ }^{60}$ Por outro lado, o $\mathrm{Nb}(\mathrm{OH})_{5}$ é formado em um ampla faixa de $\mathrm{pH}$ (0 a 13). ${ }^{61}$ Dessa forma, dentre esses hidróxidos, $\mathrm{O} \mathrm{Dy}(\mathrm{OH})_{3}$ é a espécie mais sensível ao $\mathrm{pH}$.

$\mathrm{O}$ valor de $\mathrm{pH}$ necessário para o início da precipitação de $\mathrm{Dy}(\mathrm{OH})_{3}$ pode ser calculado de acordo com a equação de equilíbrio:

$$
\mathrm{Dy}(\mathrm{OH})_{3} \rightleftharpoons \mathrm{Dy}^{3+}+3 \mathrm{OH}^{-}
$$

sendo que a equação da constante de equilíbrio é expressa como:

$$
K_{\mathrm{ps}}=\left[\mathrm{Dy}^{3+}\right] \cdot\left[\mathrm{OH}^{-}\right]^{3}
$$

Dessa forma, utilizando a concentração total de cátions de $0,1 \mathrm{~mol} / \mathrm{L}$, a concentração de íons $\mathrm{Dy}^{3+}$, para a síntese de 10Sc1DySZ, foi de $0,0018 \mathrm{~mol} / \mathrm{L}$. Aplicando a Eq.(9) a concentração de $\mathrm{OH}^{-}$é igual a 4,3.10-7 mol/L. Esse valor corresponde ao $\mathrm{pH}=7,6$. Isso significa que a formação do hidróxido na forma sólida tem início no $\mathrm{pH}=7,6$. Enquanto que abaixo desse valor, o $\mathrm{Dy}^{3+}$ permanece em solução. Para garantir a precipitação praticamente total dos íons $\mathrm{Dy}^{3+}$, a concentração inicial deve ser reduzida a cerca de $1 / 1000$, ou seja, a $1,8.10^{-6} \mathrm{~mol} / \mathrm{L}$, o que corresponde ao $\mathrm{pH}=8,6$. Portanto, para garantir a precipitação total do hidróxido e evitar a dissolução do produto formado o pH teve que ser superior a 8,6.

O precipitado foi separado por centrifugação a 2.800 rpm durante 5 minutos (Fisatom, modelo 206BL). Em seguida, foram realizados processos consecutivos de lavagem e centrifugação, onde o material foi lavado três vezes com água deionizada, e uma vez com álcool etílico e isopropílico dando origem a uma pasta, a qual mantida em estufa a $50^{\circ} \mathrm{C}$ por cerca de $50 \mathrm{~h}$. 
Depois de secos os materiais foram desaglomerados em almofariz de ágata e calcinados a $500{ }^{\circ} \mathrm{C}$ por $2 \mathrm{~h}$, utilizando uma taxa de aquecimento de $2{ }^{\circ} \mathrm{C} /$ min e resfriamento natural do forno (EDG 1700).

O fluxograma das etapas de síntese de ScSZ contendo aditivos pelo método de coprecipitação dos hidróxidos é mostrado na Figura 12. Alguns parâmetros como concentração das soluções iniciais dos cátions, $\mathrm{pH}$ de precipitação, velocidade de gotejamento, método de lavagem, velocidade e tempo de centrifugação e condições de calcinação foram fixados com base em informações reportadas na literatura ${ }^{5,24-27}$ e ensaios previamente realizados.

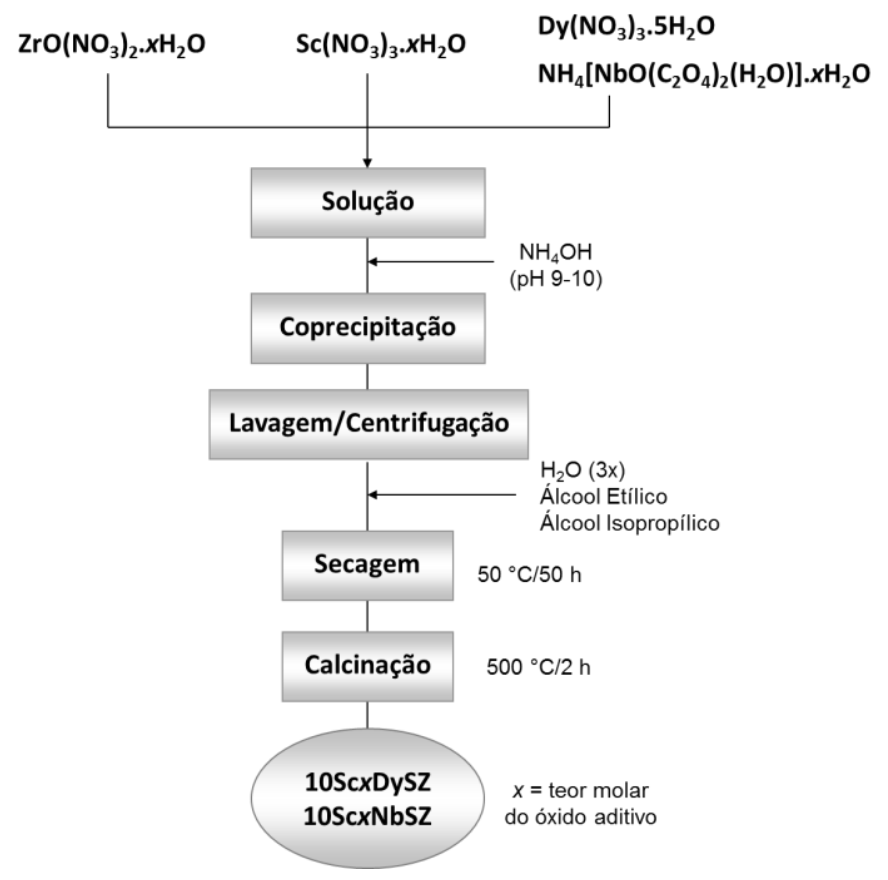

Figura 12. Fluxograma das etapas de preparação dos pós de zircônia-escândia contendo aditivos pelo método de coprecipitação dos hidróxidos.

\section{Elaboração dos Corpos de Prova}

Nesta seção serão descritos os procedimentos empregados para a elaboração dos compactos utilizados para a sinterização convencional e a sinterização assistida por campo elétrico. 
Os materiais contendo aditivos preparados por ambos os métodos de síntese utilizados, bem como, o 10ScSZ comercial, foram conformados para serem sinterizados pelo método convencional. Amostras cilíndricas de aproximadamente $3 \mathrm{~mm}$ de espessura foram conformadas por prensagem uniaxial a $50 \mathrm{MPa}$ em matriz de aço inoxidável de diâmetro igual a $5 \mathrm{~mm}$. Em seguida, foi feita compactação isostática a frio a $100 \mathrm{MPa}$. Os valores de densidade relativa a verde encontrados foram de aproximadamente $40 \%$. Após compactação, as amostras foram sinterizadas ao ar, em diferentes condições de temperatura e tempo de patamar, utilizando taxa de aquecimento de $5{ }^{\circ} \mathrm{C} / \mathrm{min}$ e resfriamento natural do forno, em forno resistivo tipo caixa (Lindberg modelo 51524, 1700C).

\section{Sinterização Assistida por Campo Elétrico}

A sinterização assistida por campo elétrico ${ }^{37}$ foi realizada em equipamento (SPS 1050, Sumitomo Coal Mining Co., Japan) do Departamento de Engenharia Mecatrônica da Escola Politécnica da Universidade de São Paulo (USP). Os pós de $10 \mathrm{ScSZ}$ contendo $1 \% \mathrm{em} \mathrm{mol}$ dos aditivos, preparados por coprecipitação, calcinados a $500{ }^{\circ} \mathrm{C}$ foram colocados em molde de grafita com diâmetro de $10 \mathrm{~mm}$. Uma folha de grafita (Perma Foil, PF40R2) foi utilizada nas paredes do molde e na interface entre os punções e o pó para proteger o molde da possível difusão de espécies químicas e facilitar a extração da amostra após tratamento térmico. O conjunto foi introduzido em um câmara selada e feito vácuo (<20 Pa), onde foram monitorados: pressão aplicada ao molde, temperatura, deslocamento e taxa de deslocamento do punção. A temperatura da parede externa do molde foi monitorada com o auxílio de um pirômetro óptico. 
Amostras foram sinterizadas na forma de discos, de $\sim 2 \mathrm{~mm}$ de espessura, na faixa de temperatura entre 1000 e $1400{ }^{\circ} \mathrm{C}$ em curtos períodos de tempo de 1 a $8 \mathrm{~min}$, com taxa de aquecimento de $100{ }^{\circ} \mathrm{C} / \mathrm{min}$ e aplicação de pressão uniaxial de $65 \mathrm{MPa}$ no patamar. O resfriamento foi realizado com taxa de $300{ }^{\circ} \mathrm{C} / \mathrm{min}$ sem aplicação de pressão. Após sinterização, os materiais foram submetidos a tratamento térmico a $900{ }^{\circ} \mathrm{C}$ por $5 \mathrm{~min}$ em forno resistivo para avaliar a possibilidade de eliminação de carbono que ficou retido na superfície das amostras.

\section{Técnicas de Caracterização}

Os pós precursores e as soluções sólidas preparadas, bem como, os corpos de prova compactados e sinterizados foram submetidos a diversas técnicas de caracterização. As condições experimentais utilizadas nas análises são descritas a seguir. Inicialmente, serão apresentadas as técnicas referentes ao estudo termodinâmico de nanopartículas de zircônia-escândia. Em seguida, as técnicas utilizadas para o estudo da influência de aditivos no sistema 10ScSZ.

\section{Zircônia-Escândia}

Técnicas de caracterização utilizadas na Universidade da Califórnia, Davis.

\section{Microanálise por Sonda Eletrônica}

As concentrações de Sc e Zr em amostras sintetizadas foram determinadas por espectroscopia por dispersão de comprimento de onda dos raios $X$ (wavelength-dispersive $X$-ray spectroscopy - WDS). As microanálises foram realizadas usando microssonda eletrônica (Cameca SX100) a uma voltagem de aceleração de $15 \mathrm{kV}$, corrente de $10 \mathrm{nA}$ e diâmetro do feixe de $5 \mu \mathrm{m}$. Antes das análises, amostras de cada composição foram compactadas uniaxialmente na forma de pastilhas, polidas em pasta de diamante de até $6 \mu \mathrm{m}$ e recobertas com carbono. A composição de cada amostra analisada foi calculada usando a média de 10 pontos. 


\section{Difratometria de Raios $X$}

A técnica de difratometria de raios $X$ foi usada para determinar o tamanho médio de cristalito dos pós calcinados de ScSZ usando um difratômetro Bruker-AXS D8 Advance operando a uma voltagem de aceleração de $40 \mathrm{kV}$ e $40 \mathrm{~mA}$ de corrente com radiação $\mathrm{Cu} \mathrm{K}_{\alpha}(\lambda=1,5405 \AA$ ). Os dados foram obtidos em uma faixa de $2 \theta$ entre 20 e $90^{\circ}$, passo de $0,01^{\circ}$ e tempo de exposição de $0,4 \mathrm{~s}$. Os parâmetros de rede e tamanho de cristalito foram calculados utilizando o programa computacional JADE, versão 6.1.

Os parâmetros de rede obtidos foram utilizados para cálculo da densidade teórica de cada composição. A identificação das estruturas cristalinas foi realizada por comparação com as fichas Powder Diffraction File (PDF) 51-1602 (monoclínica), 51-1603 (tetragonal), 64-9607 (cúbica), 64-9610 (romboédrica $\beta$ ) e 61-7752 (romboédrica $\gamma$ ) da zircônia-escândia. ${ }^{13}$ Padrão de silício foi misturado com os pós de ScSZ para garantir precisão na determinação do parâmetro de rede. A ficha PDF 27-1402 foi utilizada para o refinamento de padrão de silício.

\section{Microscopia Eletrônica de Transmissão}

A análise morfológica dos nanopós calcinados foi realizada por microscopia eletrônica de transmissão usando equipamento Philips, modelo CM12, operando a $120 \mathrm{kV}$ com filamento de $\mathrm{LaB}_{6}$.

\section{Adsorção de Nitrogênio}

A área superficial específica dos pós de ScSZ foi medida usando o equipamento Gemini VII sorption (Micromeritics), de acordo com o método de Brunauer-Emmett-Teller (BET) ${ }^{62}$ Isotermas de adsorção de nitrogênio foram coletadas na faixa de pressão relativa $\left(p / p_{0}\right.$, onde $p_{0}$ representa a pressão de saturação) de 0,05 a 0,3 a $-196{ }^{\circ} \mathrm{C}$. As amostras foram degaseificadas em uma estação de pressão reduzida (Micromeritics, VacPrep 061) a $400{ }^{\circ} \mathrm{C}$ por $12 \mathrm{~h}$ antes dos experimentos. As incertezas de área superficial encontradas foram inferiores a $1 \%$ dos valores experimentais. 
Análise Térmica

O teor de água em amostras calcinadas foi determinado por análise termogravimétrica (TG) e calorimétrica exploratória diferencial (differential scanning calorimetry - DSC) simultânea (Setaram, SetSYS Evolution) a partir de ensaios realizados a $400{ }^{\circ} \mathrm{C}$ por $12 \mathrm{~h}$ e a $1300{ }^{\circ} \mathrm{C}$, utilizando razão de aquecimento de $10{ }^{\circ} \mathrm{C} / \mathrm{min}$ sob atmosfera dinâmica de ar de $10 \mathrm{~mL} / \mathrm{min}$. Foram utilizados cerca de $20 \mathrm{mg}$ de material em cadinho aberto de Pt. O equipamento foi calibrado com um padrão de safira.

\section{Microcalorimetria de Adsorção de Água}

A energia de superfície de nanopartículas foi determinada usando uma combinação de dois equipamentos: de adsorção de água (Micromeritics, ASAP2020) equipado com uma bomba turbomolecular; e um microcalorímetro DSC (Setaram, DSC111) calibrado com Ga metálico. Nos experimentos de microcalorimetria de adsorção de água (MAA), o calor de adsorção das moléculas na superfície das nanopartículas foi medido em função da pressão relativa a $25^{\circ} \mathrm{C} .^{63,64}$

Cerca de $2 \mathrm{~m}^{2}$ de nanopartículas, calculada pela área de superfície específica, ligeiramente compactadas na forma de pastilhas foi colocado em uma das partes do tubo de sílica em formato de "garfo de duas pontas". A outra parte do tubo, a qual serve como referência, foi mantida vazia. O tubo foi colocado simultaneamente nos equipamentos de adsorção de água e de DSC, de acordo com a Figura 13. Para promover a degaseificação dos pós e garantir superfície anidra no início do experimento, o material foi submetido a tratamento térmico a $400{ }^{\circ} \mathrm{C}$ por $12 \mathrm{~h}$ dentro do sistema. A massa de material foi corrigida com base nos resultados de termogravimetria realizados nas mesmas condições. Após esse processo, microdosagens de vapor de água (2 $\mu \mathrm{mol}$ ), automaticamente controladas pela instrumentação ASAP (Figura 13), foram injetadas no sistema. O fluxo de calor entre o lado vazio do tubo e o lado contendo a amostra é detectado por termopilhas do equipamento de DSC, como em um típico experimento de DSC. 
Uma análise do tubo totalmente vazio foi realizada para a determinação do teor de água adsorvido pelo tubo e posteriormente correção das medidas contendo amostras.

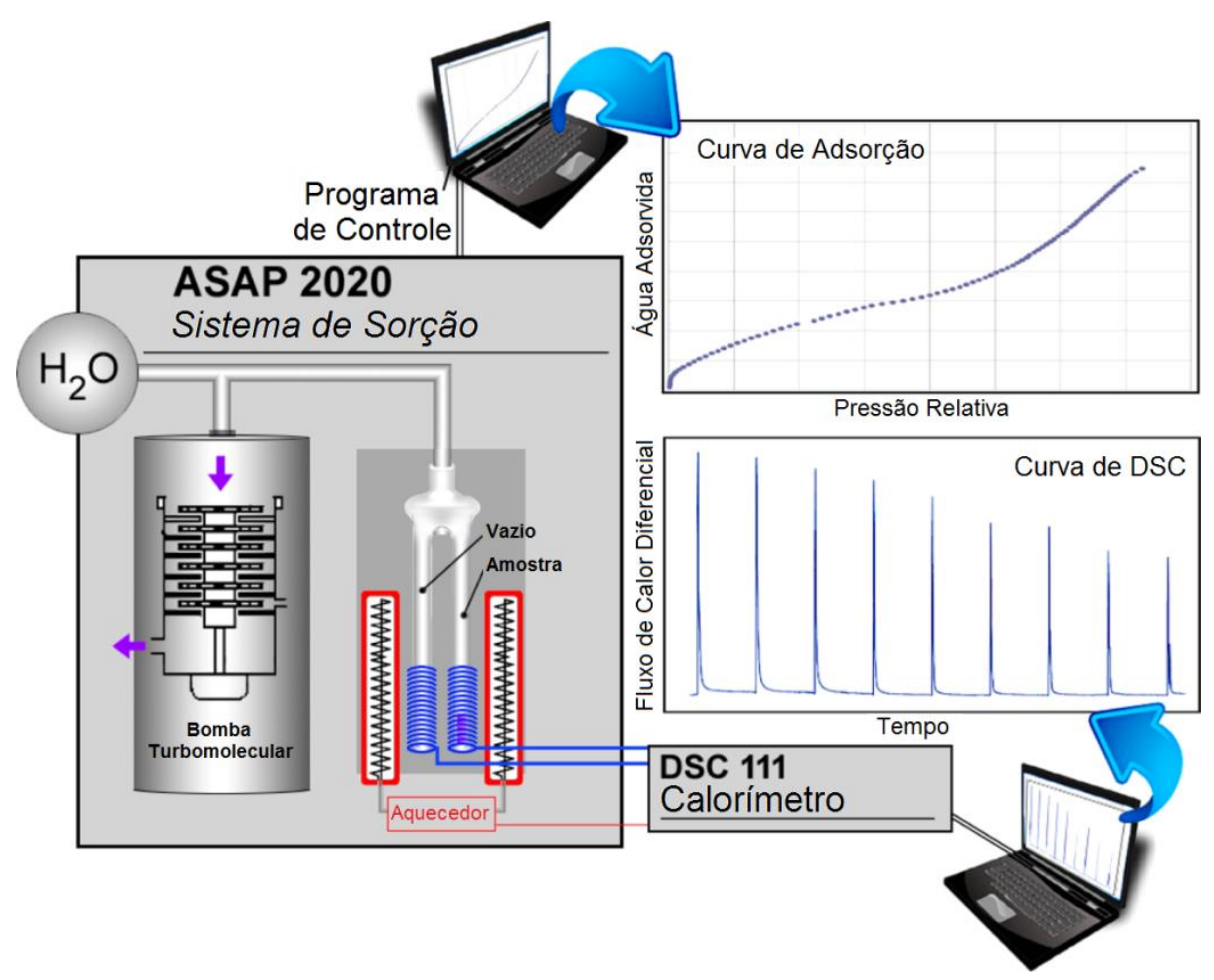

Figura 13. Representação esquemática do sistema utilizado para medidas de calor de adsorção de microdosagem controlada de vapor de água. Adaptado. ${ }^{64}$

A energia de superfície de amostras anidras foi determinada usando uma função de MATLAB 2010a personalizada reportada recentemente ${ }^{65}$ derivada da relação entre energia de superfície anidra $\left(E S_{0}\right)$ e entalpia de adsorção $\left(\Delta H_{\text {ads }}\right)^{64}$

$$
E S=E S_{0}+\theta \cdot \Delta H_{a d s}
$$

onde $\theta$ é a corbertura e ES é a energia de superfície para uma determinada cobertura de água. A curva de adsorção de água foi ajustada usando a curva de adsorção de Langmuir-BET modificada: ${ }^{33,65}$

$$
\theta=\theta_{c} \frac{b \sqrt{k}}{1+b \sqrt{k}}+\theta_{p} \frac{c k}{(1-k)[1+(c-1) k]}
$$


a qual depende de quatro variáveis; $\theta_{c}$ que é a cobertura de monocamada água quimissiosorvida, $\theta_{\mathrm{p}}$ é a cobertura fisissiosorvida, $b$ e $c$ são parâmetros de ajuste que dependem da amostra e $k$ é a pressão relativa $\left(\mathrm{p} / \mathrm{p}_{0}\right)$.

\section{Calorimetria de Dissolução à Alta Temperatura}

A calorimetria de dissolução de óxidos à alta temperatura é uma técnica utilizada para a determinação de energias envolvidas em eventos físico-químicos em temperaturas superiores a $400^{\circ} \mathrm{C}$. A principal vantagem desta técnica é a determinação de valores de entalpia de materiais refratários, como fusão, oxidação, desidratação, formação e capacidade calorífica. ${ }^{66,67}$

O microcalorímetro do tipo Tian-Calvet, utilizado para esse tipo de experimento, mede o fluxo de calor entre a amostra e uma fonte de calor, a uma temperatura constante. ${ }^{67}$ A representação esquemática do calorímetro de alta temperatura durante um típico experimento de dissolução (conhecido como drop solution - DS) é apresentada na Figura 14. O calorímetro é constituído por duas câmaras de medida. Enquanto a amostra é introduzida em uma câmara, a outra atua como referência. Cada câmara é rodeada por um conjunto de 56 termopares de Pt-PtRh conectados a um bloco metálico de Inconel, mantidos a uma temperatura constante.

$\mathrm{O}$ sinal gerado pelos termopares, em $\mu \mathrm{V}$, é detectado por um microvoltímetro e, então, transmitido para um programa computacional (Calisto, Setaram). Os termopares de cada câmara de medida são conectados em série e formam um sistema denominado de termopilhas.

As termopilhas possibilitam a detecção de pequenas variações de temperatura no interior do calorímetro da ordem de 0,01 a $0,001{ }^{\circ} \mathrm{C}$. Dessa forma, durante as reações químicas, o fluxo de calor é determinado por medidas diretas de temperatura entre pontos da câmara e do bloco de Inconel, onde inicialmente há uma rápida variação do sinal, o qual, em seguida, retorna exponencialmente à linha de base. A energia envolvida no processo de dissolução é proporcional à área do pico calorimétrico e pode ser calculada pelo fator de correção, o qual é determinado pela calibração usando uma amostra padrão de $\alpha-\mathrm{Al}_{2} \mathrm{O}_{3}$. 
Nas medidas de dissolução de nanopartículas, as quais possuem elevada área superficial, o efeito resultante de calor, referido como entalpia de dissolução, consiste da variação de temperatura causada pela introdução da amostra à temperatura ambiente dentro do calorímetro em alta temperatura, da entalpia de desidratação e calor de dissolução do material. Dessa forma, após esses experimentos, é necessário realizar correções de entalpia com base em um ciclo termoquímico apropriado aplicando a lei de Hess.

No entanto, em materiais com tamanho médio de grãos elevado e, portanto, pequenas áreas superficiais, o calor de desidratação é desprezível. Dessa forma, de modo a avaliar a confiabilidade das correções realizadas pelo ciclo termoquímico, foi determinado o calor de dissolução a partir de medidas diretas de dissolução em alta temperatura de amostras monofásicas de zircônia-escândia calcinadas a $1500^{\circ} \mathrm{C}$ por $15 \mathrm{~h}$.

Para esses experimentos, aproximadamente $5 \mathrm{mg}$ de material ligeiramente compactado na forma de pastilha foi pesado em condições ambientes e introduzido no calorímetro em um solvente de $3 \mathrm{Na}_{2} \mathrm{O}_{4} 4 \mathrm{MoO}_{3}$ a $700{ }^{\circ} \mathrm{C}$. Gás oxigênio foi introduzido à câmara $(40 \mathrm{~mL} / \mathrm{min})$ e ao solvente $(3,5 \mathrm{~mL} / \mathrm{min})$ para manter a atmosfera oxidativa constante no interior do sistema durante o experimento e facilitar a dissolução das amostras.

A calibração do calorímetro foi realizada usando cerca de $5 \mathrm{mg}$ de $\alpha-\mathrm{Al}_{2} \mathrm{O}_{3}$. Antes dos experimentos, todas as amostras foram equilibradas por, pelo menos, $72 \mathrm{~h}$ em um ambiente com atmosfera de ar e temperatura controlada e umidade relativa a 50\%. O teor de hidratação das amostras foi determinado por experimentos de termogravimetria. De modo a obter um valor médio preciso, foram analisadas, pelo menos, 8 amostras de cada composição estudada. 


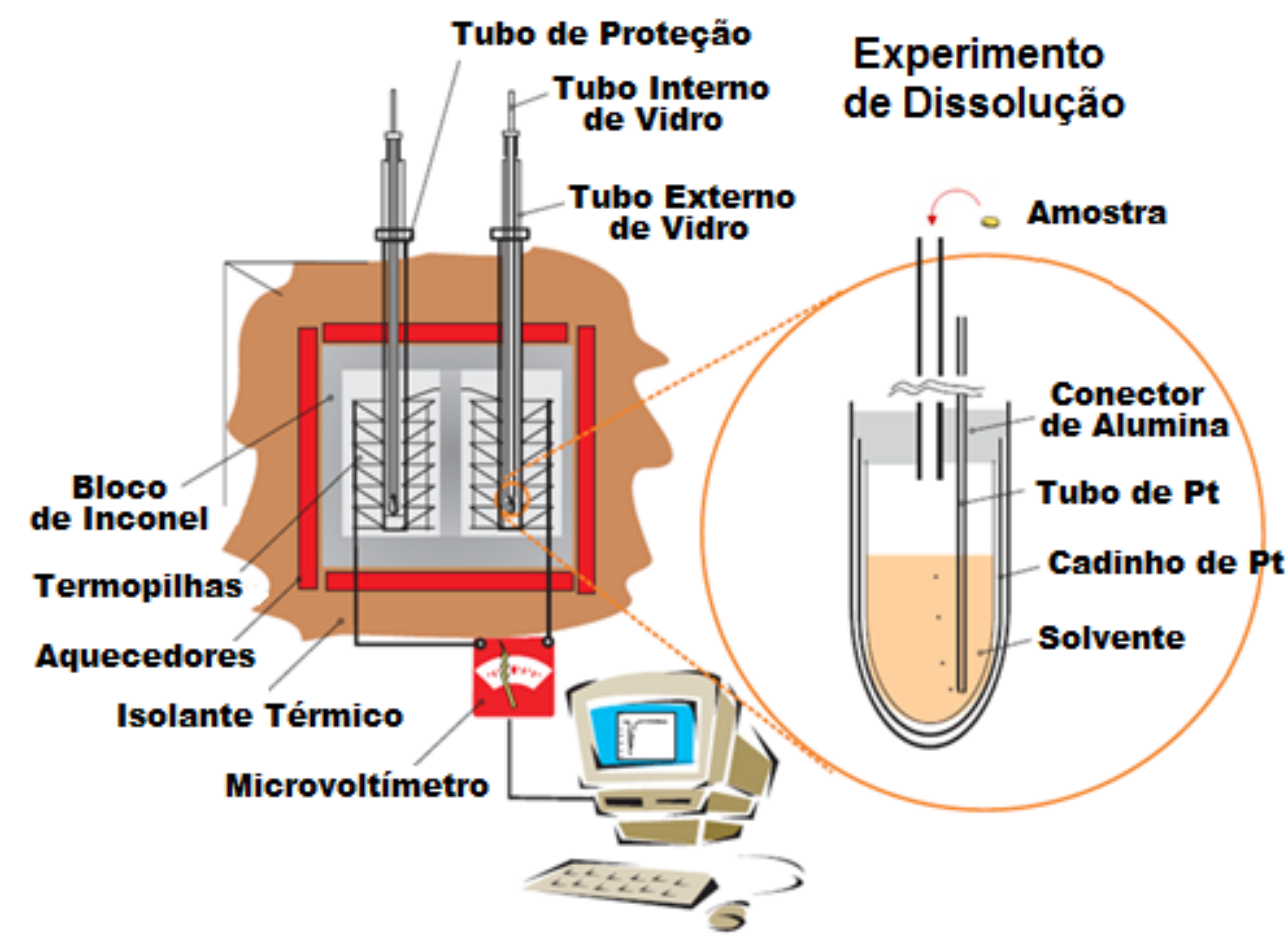

Figura 14. Representação esquemática da secção transversal do calorímetro de dissolução à alta temperatura. Adaptado. ${ }^{67}$

Uma breve representação esquemática do procedimento experimental realizado nesse trabalho é apresentada na Figura 15. A composição química de amostras calcinadas foi determinada por microssonda eletrônica. Difração de raios $X$ foi usada para verificar a estrutura cristalina dos materiais e o tamanho médio de cristalito foi calculado pelo programa JADE. Foram determinados: o teor de hidratação após tratamento térmico a $400{ }^{\circ} \mathrm{C}$ por $12 \mathrm{~h}$, área superficial específica e energia de superfície de amostras nanométricas e monofásicas de ScSZ.

Por fim, a entalpia de dissolução foi obtida. Foi determinado, por ensaios de TG/DSC, o teor de água de pós armazenados por $72 \mathrm{~h}$ em um ambiente com umidade relativa a $50 \%$. 


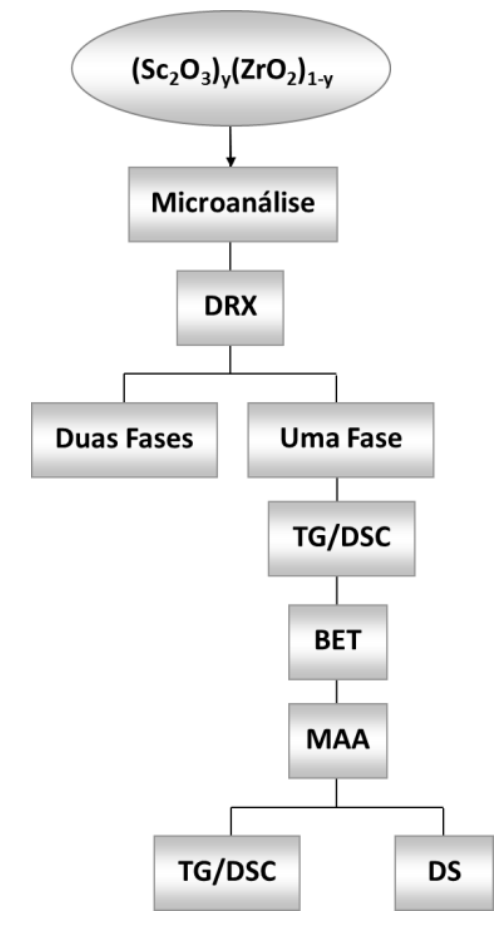

Figura 15. Fluxograma das etapas de caracterização do sistema ScSZ.

\section{Zircônia-Escândia Contendo Aditivos}

Técnicas de caracterização utilizadas no IPEN e na USP.

\section{$\underline{\text { Análise Térmica }}$}

A caracterização térmica dos precursores sintetizados por coprecipitação foi realizada por meio das medidas de TG e análise térmica diferencial (thermal differential analysis - DTA) simultânea (Netzsch, STA409), bem como, por DSC. Para esses experimentos, foi utilizado aproximadamente $15 \mathrm{mg}$ de amostra. Os ensaios de TG/DTA foram realizados a partir da temperatura ambiente até $1100{ }^{\circ} \mathrm{C}$ com razão de aquecimento e resfriamento de $10^{\circ} \mathrm{C} / \mathrm{min}$, sob atmosfera dinâmica de ar sintético ( $5 \mathrm{~mL} / \mathrm{min})$, utilizando a-alumina como material de referência. Ensaios de TG (Shimadzu, TGA-50) também foram realizados a partir da temperatura ambiente até 500 e $550{ }^{\circ} \mathrm{C}$ com razão de aquecimento de $10{ }^{\circ} \mathrm{C} / \mathrm{min}$, sob atmosfera dinâmica de $\mathrm{N}_{2}(50 \mathrm{~mL} / \mathrm{min})$ e cadinho aberto de Pt. 
Os ensaios de DSC (Shimadzu, DSC-50) foram realizados no Laboratório de Análise Térmica Prof. Dr. Ivo Giolito (LATIG) no Instituto de Química da USP (IQ). A faixa de temperatura estudada foi a partir da temperatura ambiente até $550{ }^{\circ} \mathrm{C}$ com razão de aquecimento de $10{ }^{\circ} \mathrm{C} / \mathrm{min}$, atmosfera dinâmica de $\mathrm{N}_{2}$ (100 mL/min) e cadinho de alumínio. O equipamento foi previamente calibrado utilizando padrão de In metálico, com pureza de 99,99\%. A calibração para energia foi feita com base na entalpia de fusão do $\ln , \Delta H_{\text {fus }}=28,5 \mathrm{~J} / \mathrm{g} .{ }^{68}$

Ensaios de DTA (TA Instruments, SDT-Q600) de amostras sinterizadas foram realizados na faixa de temperatura de 200 a $700{ }^{\circ} \mathrm{C}$ em ciclo térmico com razão de aquecimento e resfriamento de $10{ }^{\circ} \mathrm{C} / \mathrm{min}$ em ar sintético e cadinho aberto de Pt. Alumínio metálico (99,9\%) foi utilizado para calibração. Esses experimentos foram realizados no Centro de Tecnologia das Radiações (CTR).

\section{Difratometria de Raios $X$}

A caracterização estrutural dos materiais como recebidos e após tratamentos térmicos foi feita por difratometria de raios $X$ (Bruker-AXS, D8 Advance) utilizando a radiação $\mathrm{Cu} \mathrm{K}_{\alpha}(\lambda=1,5405 \AA)$ e filtro de $\mathrm{Ni}$, na faixa angular de $2 \theta$ entre 20 e $80^{\circ}$, com passo de $0,05^{\circ}$ e tempo de exposição de $2 \mathrm{~s}$. Foram utilizadas as fichas PDF mencionadas anteriormente para identificação das fases cristalográficas. Os parâmetros de rede foram determinados pelo programa UnitCell.

O tamanho médio de cristalito $(D)$ de pós calcinados foi estimado pelo método de Debye-Scherrer ${ }^{69}$ de acordo com a seguinte equação:

$$
D=\frac{0,9 \lambda}{\beta \cos (\theta)}
$$

onde $\lambda$ é o comprimento de onda da radiação eletromagnética, $\beta$ é largura na meia altura do pico de difração e $\theta$ é o ângulo (posição) de difração do pico. Para o cálculo do tamanho médio de cristalito foram usadas as reflexões (111) e (101) das fases cúbica e romboédrica $(\beta)$, respectivamente. A correção instrumental foi feita com padrão de silício. 
Amostras sinterizadas a $1450{ }^{\circ} \mathrm{C}$ por tempo de patamar nulo foram pulverizadas e submetidas à difratometria de raios $X$ em câmara de alta temperatura. As análises foram feitas em difratômetro (Bruker-AXS, D8 Advance) com geometria Bragg-Brentano $\theta-\theta$, equipado com um detector sensível à posição (Braun-PSD) em uma câmara com elemento aquecedor (Anton Paar HTK 1400). As medidas foram feitas, em ciclos térmicos de aquecimento $e$ resfriamento, entre 30 e $700{ }^{\circ} \mathrm{C}$ na faixa de $2 \theta$ entre 47 e $54^{\circ} \mathrm{com}$ passo de $0,073^{\circ}$.

\section{Análise Elementar (CHN)}

A análise quantitativa dos elementos carbono, hidrogênio e nitrogênio nos pós precursores de 10Sc1NbSZ e 10Sc1DySZ sintetizados por coprecipitação foi realizada na Central Analítica do IQ-USP. O equipamento utilizado foi 0 Perkin Elmer, CHN 2400.

\section{Fluorescência de Raios X}

A técnica de fluorescência de raios X (Shimadzu, EDX-720) foi utilizada para análise composicional dos materiais calcinados e sinterizados.

\section{Espectroscopia de Infravermelho}

A técnica de espectroscopia de infravermelho com transformada de Fourier (FTIR) foi utilizada para determinar a composição química da superfície das partículas, utilizando o espectrômetro Thermo Nicolet Magna 560. Os espectros foram registrados no modo de refletância difusa (DRIFT) com varredura de 4000 a $500 \mathrm{~cm}^{-1}$. Os espectros de FTIR-DRIFT são importantes para a caracterização de superfícies devido à baixa penetração da radiação infravermelha nos sólidos que faz com que a refletância da radiação enfatize as características químicas da superfície dos pós. Os espectros foram registrados no Departamento de Engenharia Metalúrgica e de Materiais da Escola Politécnica da USP. 
Os espectros de absorção na região do infravermelho também foram registrados utilizando o método do $\mathrm{KBr}$, utilizando o espectrômetro Bomem MB100 na faixa de 300 a $800 \mathrm{~cm}^{-1}$ na Central Analítica IQ-USP.

\section{Microscopia Eletrônica de Transmissão}

Amostras calcinadas foram observadas em microscópio eletrônico de transmissão (Jeol, JEM 2100) do Laboratório de Microscopia Eletrônica do Centro de Ciência e Tecnologia de Materiais (CCTM).

\section{Microscopia Eletrônica de Varredura}

Imagens das partículas dos óxidos como recebidos foram obtidas por microscópio eletrônico de varredura (MEV) usando fonte de filamento de tungstênio (Tabletop, Hitachi TM3000). A caracterização microestrutural de amostras sinterizadas polidas e atacadas termicamente, bem como, de superfícies fraturadas, foi realizada por MEV com fonte de emissão eletrostática, FEG (FEI, Inspect F50).

O tamanho médio de grãos $(G)$ de compactos sinterizados foi determinado utilizando o método de Mendelson ${ }^{70}$ ou método dos interceptos. Foram obtidas diversas imagens, em diferentes microrregiões de cada amostra, de modo a serem analisados, pelo menos, 500 grãos por amostra.

\section{$\underline{\text { Dilatometria }}$}

A análise da retração linear de compactos a verde foi realizada em dilatômetro (Anter, 1161 Unitherm). Amostras cilíndricas foram compactadas uniaxialmente em matriz de aço inoxidável de diâmetro igual a $5 \mathrm{~mm}$ com aplicação de pressão de $50 \mathrm{MPa}$, seguido de compactação isostática a frio (100 MPa), obtendo-se amostras com densidades relativas a verde em torno de $40 \%$. As medidas de dilatometria foram realizadas a partir da temperatura ambiente até $1450{ }^{\circ} \mathrm{C}$ com razão de aquecimento e resfriamento de $10{ }^{\circ} \mathrm{C} / \mathrm{min}$, sob atmosfera estática de ar. 


\section{Densidade Aparente}

A densidade aparente das amostras sinterizadas foi determinada por meio dos métodos geométrico e de imersão em água, utilizando o princípio de Arquimedes, e comparada com a densidade teórica calculada. O método de imersão foi utilizado apenas em amostras com densidade geométrica relativa maior que $85 \%$. Para o método geométrico, as dimensões das amostras foram determinadas por micrômetro da marca Tesa. Foram feitas 10 medidas de diâmetro e 10 de espessura, para obter precisão adequada neste tipo de medida. A massa foi determinada em balança analítica (Mettler, H315), a qual foi também utilizada para o método de imersão, onde foram realizadas 10 determinações de massa imersa, úmida e seca.

\section{Espectroscopia de Impedância}

A condutividade elétrica foi determinada por meio da técnica de espectroscopia de impedância. As medidas foram realizadas no intervalo de frequência de $5 \mathrm{~Hz}$ a $13 \mathrm{MHz}$ na faixa de temperatura entre 300 e $800{ }^{\circ} \mathrm{C}$, com uma tensão aplicada de $200 \mathrm{mV}$, utilizando-se um analisador de impedância HP 4192A, acoplado a um controlador HP 362. A temperatura foi monitorada com termopar tipo $\mathrm{K}$ (Cromel/Alumel) posicionado próximo às amostras. Para as medidas elétricas realizou-se a deposição dos eletrodos em faces opostas das amostras com aplicação de pasta de platina (Demetron, A308) seguida de cura da resina a $800^{\circ} \mathrm{C}$. Os dados das medidas elétricas foram coletados e analisados por meio de programa computacional. ${ }^{71}$ 


\section{Envelhecimento Térmico}

Amostras de $10 \mathrm{Sc} 0.5 \mathrm{NbSZ}$ sintetizadas por mistura de óxidos e sinterizadas a $1500{ }^{\circ} \mathrm{C}$ por $5 \mathrm{~h}$ foram submetidas a tratamentos térmicos a $600{ }^{\circ} \mathrm{C}$ por longos períodos de tempo (até 170 h) em forno resistivo do tipo caixa (EDG 1700). Após tratamentos térmicos, a condutividade elétrica dos materiais foi determinada utilizando a técnica de espectroscopia de impedância a uma temperatura fixa de $700^{\circ} \mathrm{C}$.

A caracterização estrutural dessas amostras também foi verificada. Para isso, medidas de difração de raios $X$ foram realizadas em um intervalo de $2 \theta$ entre 48 e $53^{\circ}, 0,02^{\circ}$ e $5 \mathrm{~s}$ com a finalidade de verificar a possível formação da estrutura romboédrica na matriz cúbica. Para assegurar reprodutibilidade nesse tipo de análise, os tratamentos térmicos foram realizados em três amostras de mesma composição, sendo uma usada para análise estrutural e duas para medidas elétricas. 


\section{RESULTADOS E DISCUSSÃO}

Este capítulo está dividido em duas seções principais, nas quais serão apresentados os resultados referentes à caracterização dos materiais sintetizados pelo método de coprecipitação de hidróxidos e por mistura de óxidos, respectivamente.

\section{Coprecipitação de Hidróxidos}

Essa seção está dividida em duas partes, onde inicialmente serão apresentados os principais resultados do estudo termodinâmico de nanopartículas de zircônia-escandia ( 0 a $20 \%$ mol). Em seguida, serão mostrados e discutidos os resultados da caracterização de zircônia-10\% mol de escândia contendo aditivos.

\section{Zircônia-Escândia}

A Tabela $V$ sumariza a concentração de $\mathrm{Sc}_{2} \mathrm{O}_{3}$ das composições estudadas. A composição determinada para cada solução sólida sintetizada foi determinada com base nos resultados de microanálises.

Tabela V. Concentração de escândia, em porcentagem molar, e composição real, de amostras de $y \mathrm{ScSZ}$, determinadas por microanálise por sonda eletrônica.

\begin{tabular}{cc}
\hline $\mathbf{S c}_{2} \mathbf{O}_{3}$ (\% molar) & Composição Real $(y)$ \\
\hline 0 & 0 \\
$1,08 \pm 0,02$ & 1,1 \\
$2,10 \pm 0,06$ & 2,1 \\
$3,12 \pm 0,04$ & 3,1 \\
$4,17 \pm 0,16$ & 4,2 \\
$6,29 \pm 0,30$ & 6,3 \\
$8,40 \pm 0,44$ & 8,4 \\
$10,60 \pm 0,53$ & 10,6 \\
$11,60 \pm 0,23$ & 11,6 \\
$12,93 \pm 0,50$ & 12,9 \\
$13,64 \pm 0,34$ & 13,6 \\
$14,34 \pm 0,83$ & 14,3 \\
$19,33 \pm 0,78$ & 19,3 \\
\hline
\end{tabular}


As imagens de mapeamento de raios $\mathrm{X}$ dos elementos $\mathrm{Zr}$ e Sc para uma amostra contendo $3,1 \%$ mol de $\mathrm{Sc}_{2} \mathrm{O}_{3}$ (3.1ScSZ) são mostradas na Figura 16.
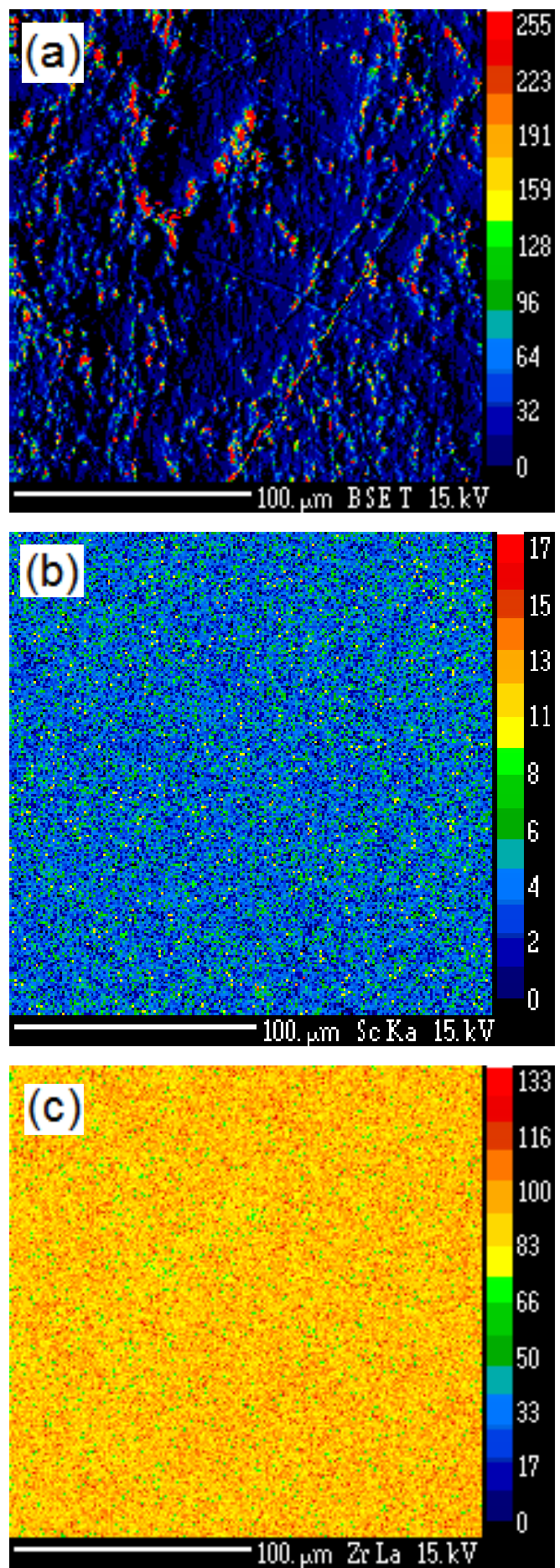

Figura 16. Mapeamento de raios $X$ de $3.1 \mathrm{ScSZ}$. (a) Imagem de elétrons retroespalhados; (b) mapeamento de Sc; (c) mapeamento de Zr. 
Na micrografia de elétrons retroespalhados (Figura 16a), a intensidade de cor é proporcional à rugosidade da superfície, sendo que a cor vermelha está localizada em níveis mais elevados. Por outro lado, nas imagens de mapeamento de Sc (Figura 16b) e $\mathrm{Zr}$ (Figura 16c), a intensidade de cor é proporcional à concentração do elemento presente. A distribuição homogênea de cátions, evidenciada nas micrografias, foi encontrado para todas as amostras de yScSZ. Isso confirma o elevado grau de homogeneidade obtido a partir da síntese pelo método de coprecipitação de hidróxidos. ${ }^{25}$

\section{Caracterização Estrutural}

Amostras de cada composição foram calcinadas em várias condições variando temperatura e tempo de patamar com a finalidade de obter materiais monofásicos e nanoestruturados. Cinco estruturas polimórficas (monoclínica, tetragonal, cúbica, romboédrica $\beta$ e $\gamma$ ) foram encontradas dentro da faixa molar de 0 a $20 \%$ de escândia, o que está de acordo com o diagrama de fases de temperatura e composição (Figura 5). ${ }^{17}$

Os difratogramas de raios $X$ da zircônia pura são mostrados na Figura 17. O tamanho médio de cristalito determinado pelo programa JADE está indicado para cada amostra. As fichas PDF 51-1603 e 51-1602 das fases tetragonal $(t)$ e monoclínica $(m)$, respectivamente, estão indicadas na parte inferior. Menores tamanhos de partículas promoveram a estabilização da estrutura tetragonal na zircônia. No entanto, o aumento do tamanho das partículas favoreceu a estabilização da fase monoclínica à temperatura ambiente.

Uma vez que os pós foram aquecidos e resfriados lentamente durante tratamento térmico de calcinação, esses resultados sugerem que a transformação de fase tetragonal-monoclínica é uma reação favorecida termodinamicamente que depende do tamanho das partículas. Contudo, os métodos de síntese também apresentam forte influência na estrutura cristalina das cerâmicas. Foi demonstrado que a estrutura monoclínica pode ser totalmente estabilizada à temperatura ambiente na zircônia pura com partículas menores que $10 \mathrm{~nm}$ utilizando o método solvotérmico. ${ }^{72}$ 


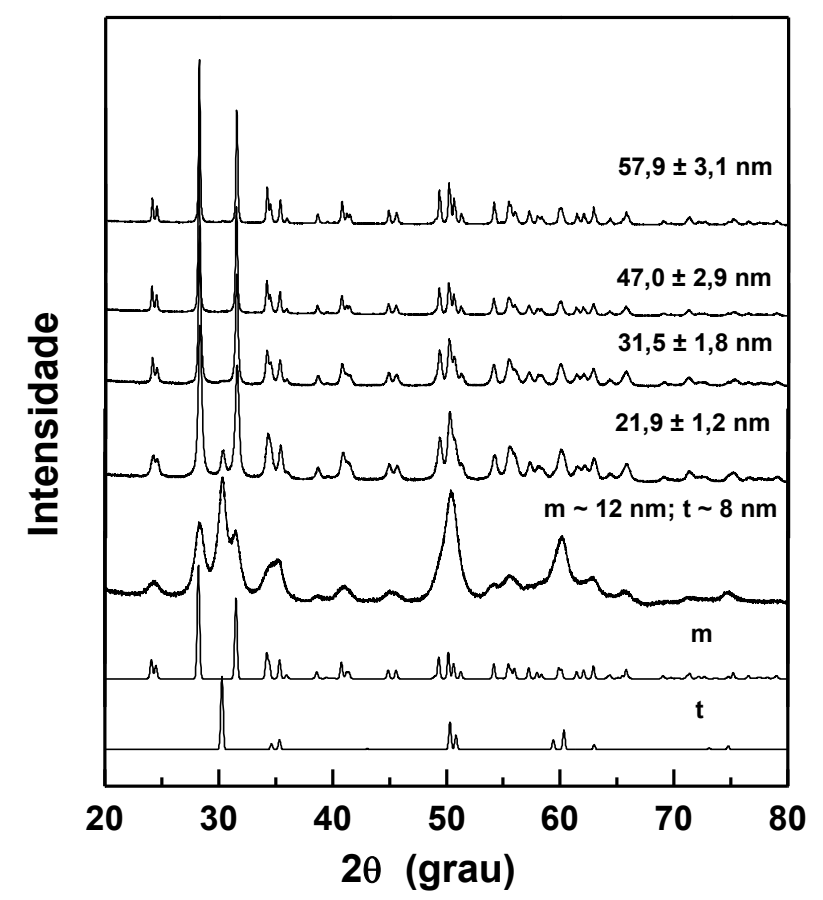

Figura 17. Difratogramas de raios $\mathrm{X}$ de nanopartículas de $\mathrm{ZrO}_{2}$.

Comportamento similar foi observado para a zircônia contendo 1,1 e 2,1\% mol de escândia (Figuras 18 e 19), onde a completa estabilização da fase tetragonal foi obtida para tamanho de partículas de 7,1 e 7,8 nm, respectivamente.

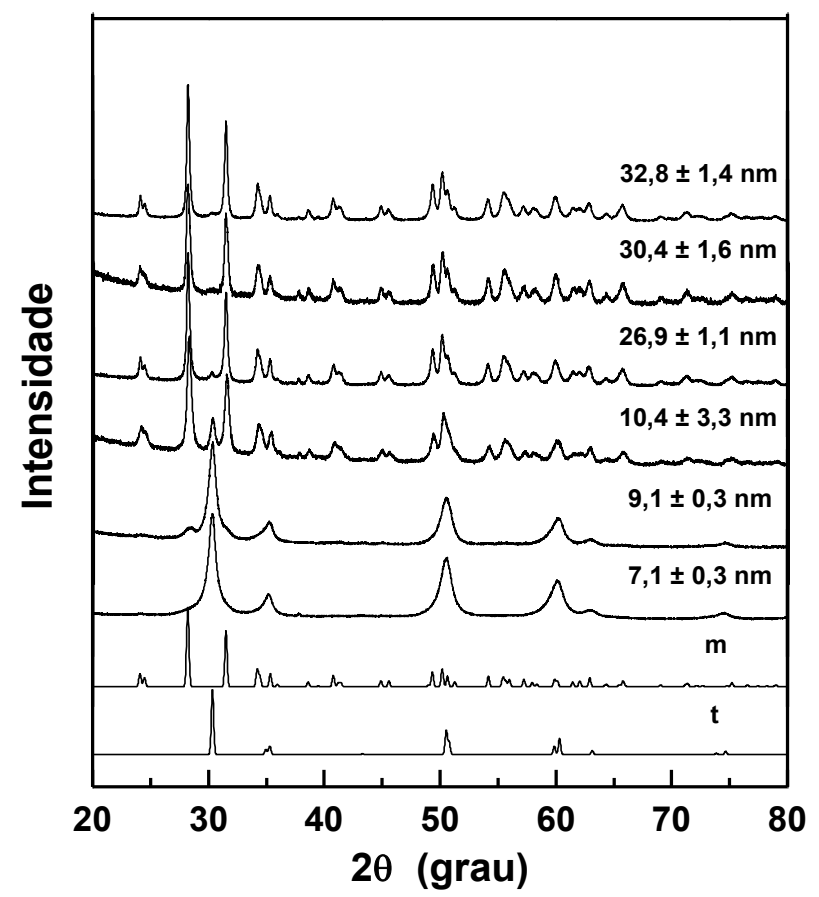

Figura 18. Difratogramas de raios $X$ de nanopartículas de 1.1ScSZ. 


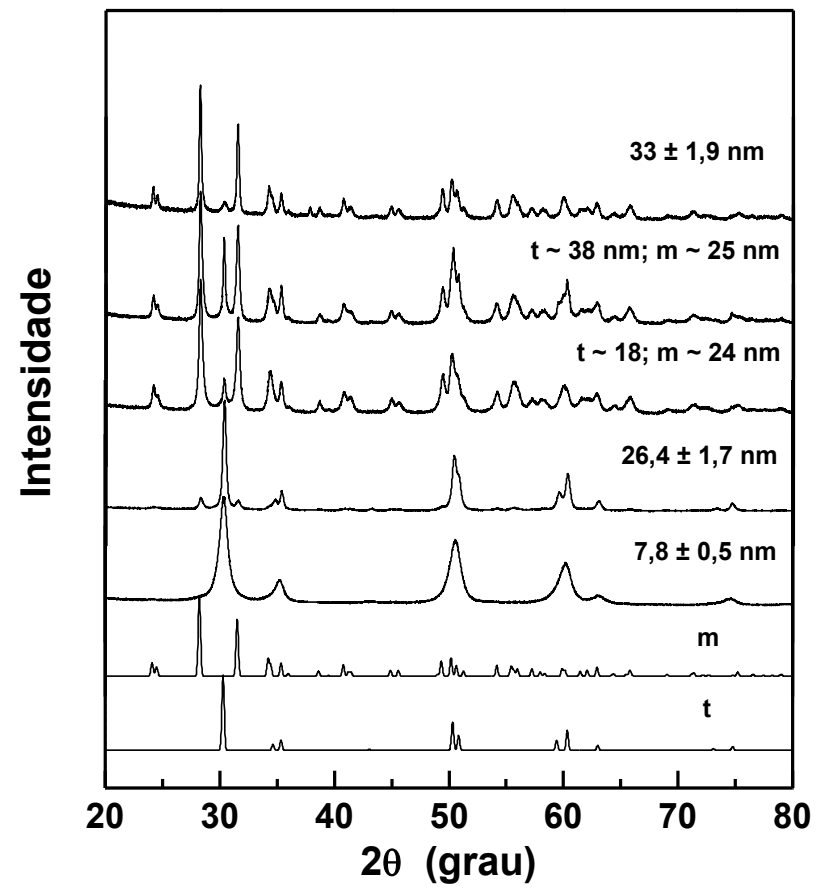

Figura 19. Difratogramas de raios $X$ de nanopartículas de 2.1ScSZ.

Apenas a fase tetragonal foi identificada, em uma ampla faixa de tamanho médio de partículas, para os teores molares de escândia entre 3,1 e 6,2\%, como pode ser observado nas Figuras 20-22. As fichas PDF 51-1603 e 64-9607 das fases tetragonal $(t)$ e cúbica $(c)$, respectivamente, estão indicadas na parte inferior das Figuras. As diferenças entre as fases cúbica e tetragonal podem ser claramente observadas na região de $60^{\circ}$. No entanto, há dificuldade de diferenciar essas estruturas por difração de raios $\mathrm{X}$ devido ao alargamento dos picos de difração para partículas inferiores a $10 \mathrm{~nm}$. 


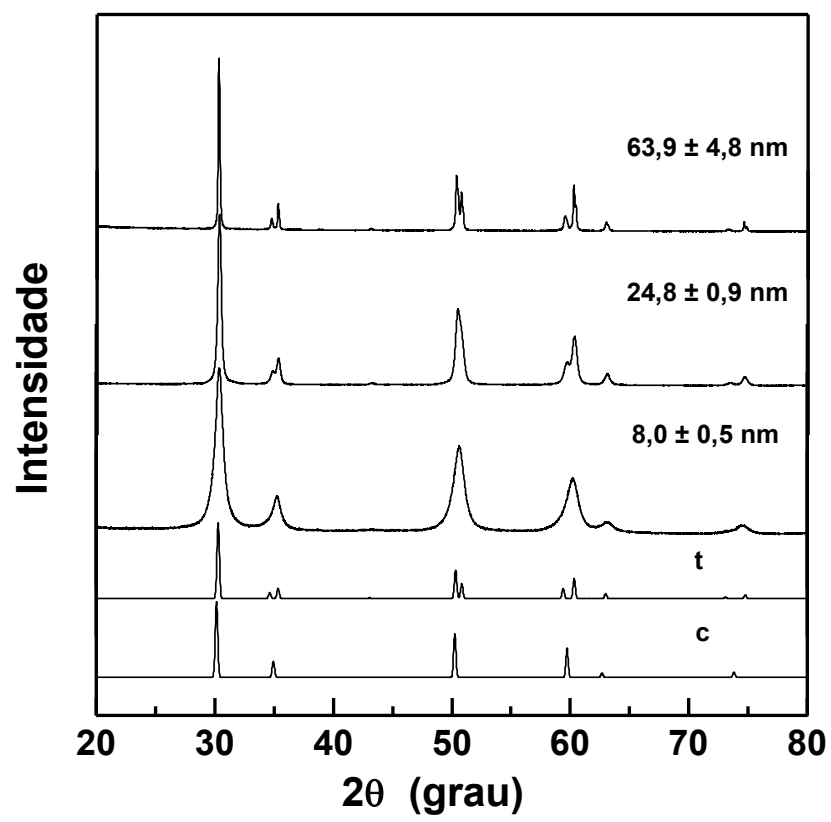

Figura 20. Difratogramas de raios $X$ de nanopartículas de 3.1ScSZ.

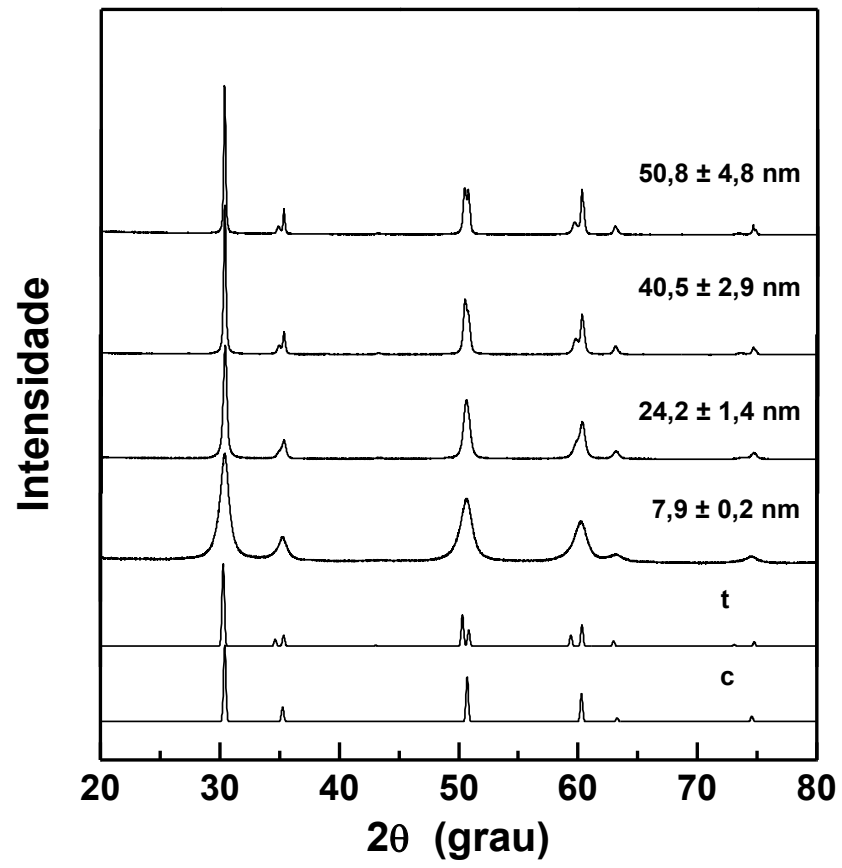

Figura 21. Difratogramas de raios $X$ de nanopartículas de 4.2ScSZ. 


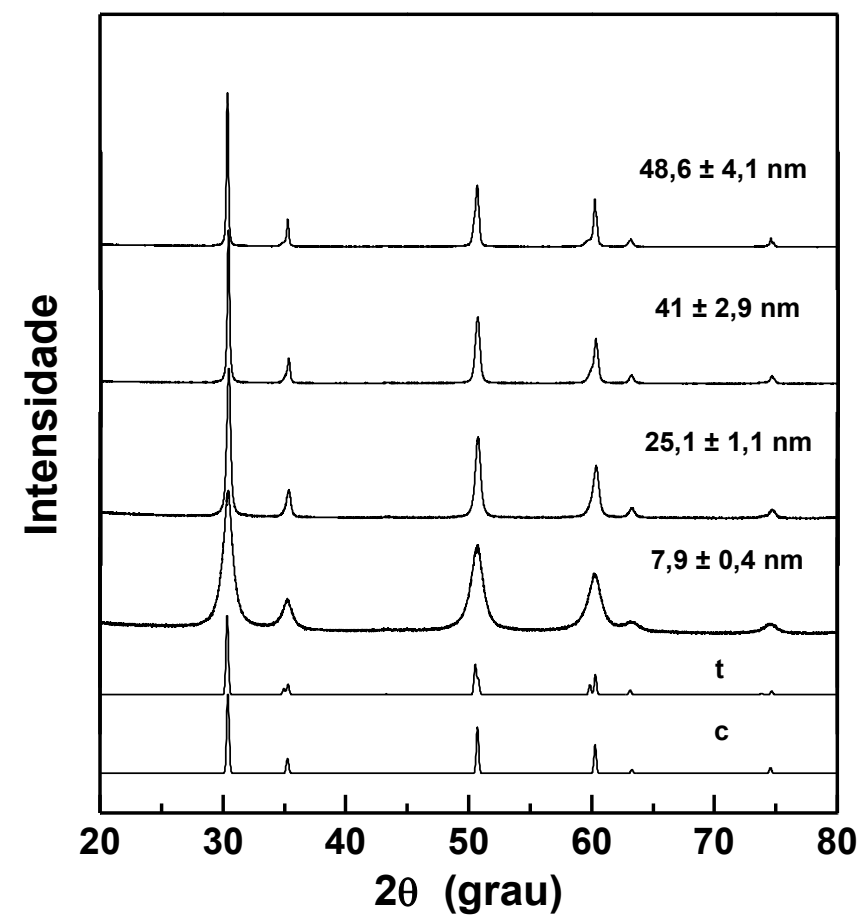

Figura 22. Difratogramas de raios $X$ de nanopartículas de 6.2ScSZ.

Por outro lado, apenas a fase cúbica pode ser atribuída para nanopartículas de 8.4ScSZ, como pode ser observado na Figura 23.

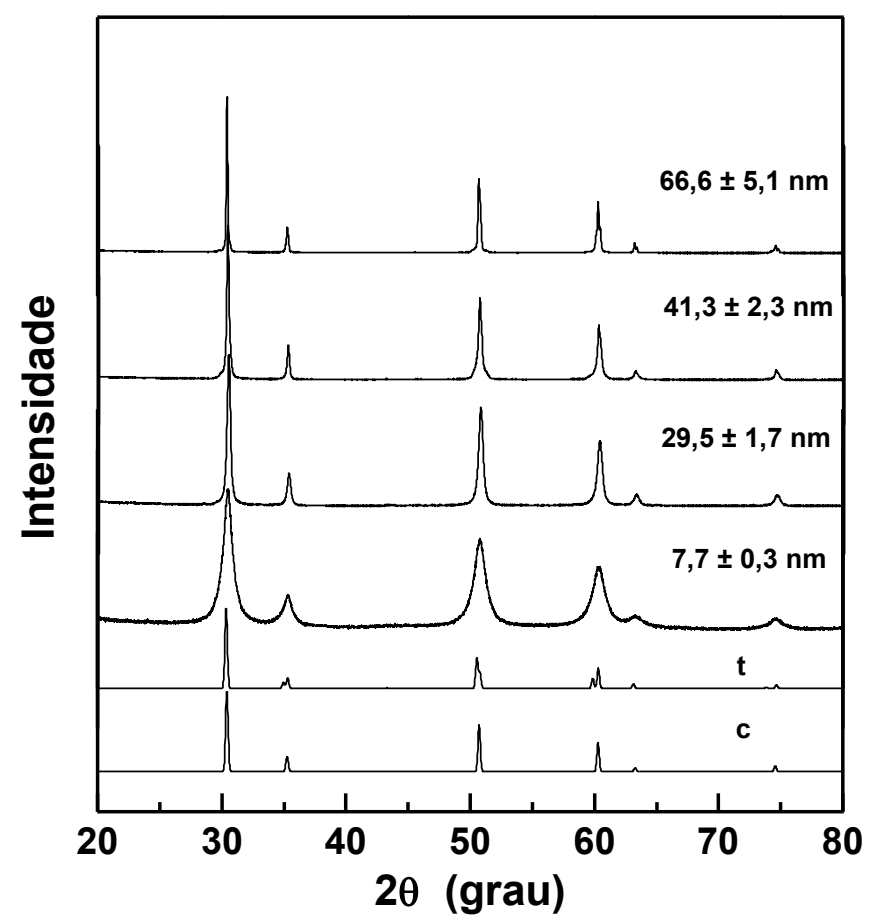

Figura 23. Difratogramas de raios $X$ de nanopartículas de 8.4ScSZ. 
Os difratogramas de raios $X$ das amostras 10.6ScSZ, 11.6ScSZ e 12.9ScSZ são mostrados nas Figuras 24-26. As fichas PDF 64-9610 e 64-9607 das fases romboédrica $(\beta)$ e cúbica $(c)$, respectivamente, estão indicadas na parte inferior. As três composições apresentaram ambos os polimorfos $c$ e $\beta$, sendo que os picos de difração da fase $\beta$ foram encontrados para maiores partículas. De acordo com os difratogramas, o limite para a estabilização da fase cúbica pode ser estimado por volta de $27 \mathrm{~nm}$. Esses resultados estão de acordo com trabalhos recentemente reportados, nos quais também mostram a dependência da estabilização da fase cúbica em função do tamanho de cristalito para nanofibras de $10 S c S Z{ }^{35}$ e nanopartículas de $10 S c S Z, 12 S c S Z$ e $14 S c S Z .^{15,73}$

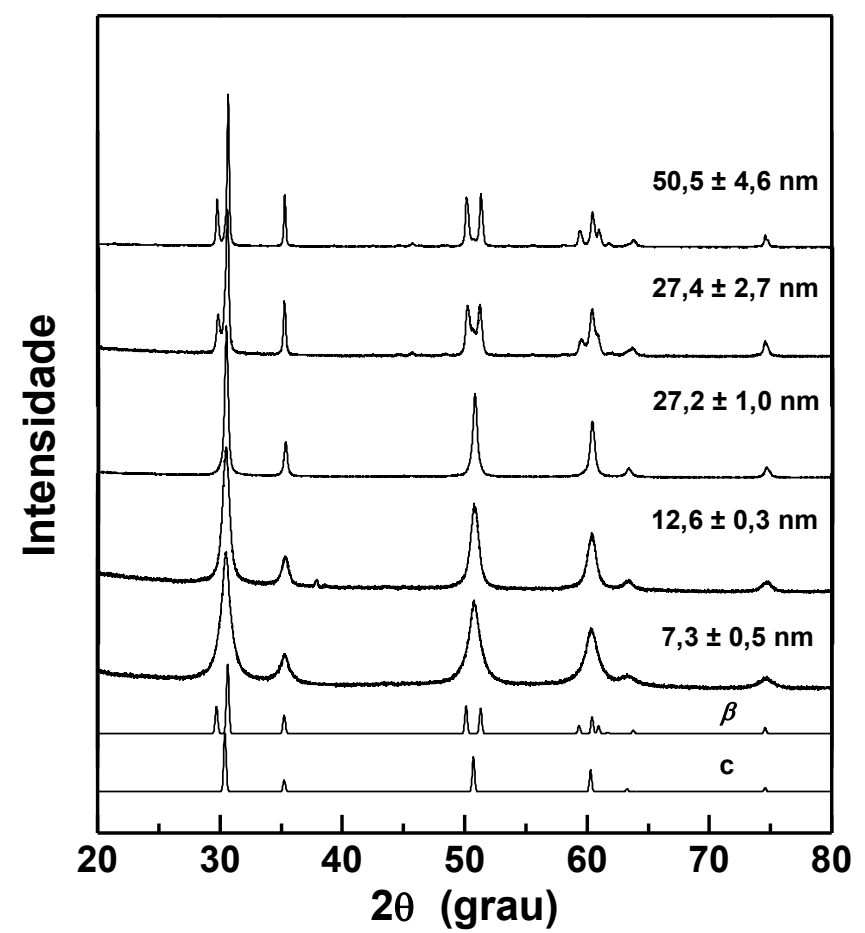

Figura 24. Difratogramas de raios $X$ de nanopartículas de 10.6ScSZ. 


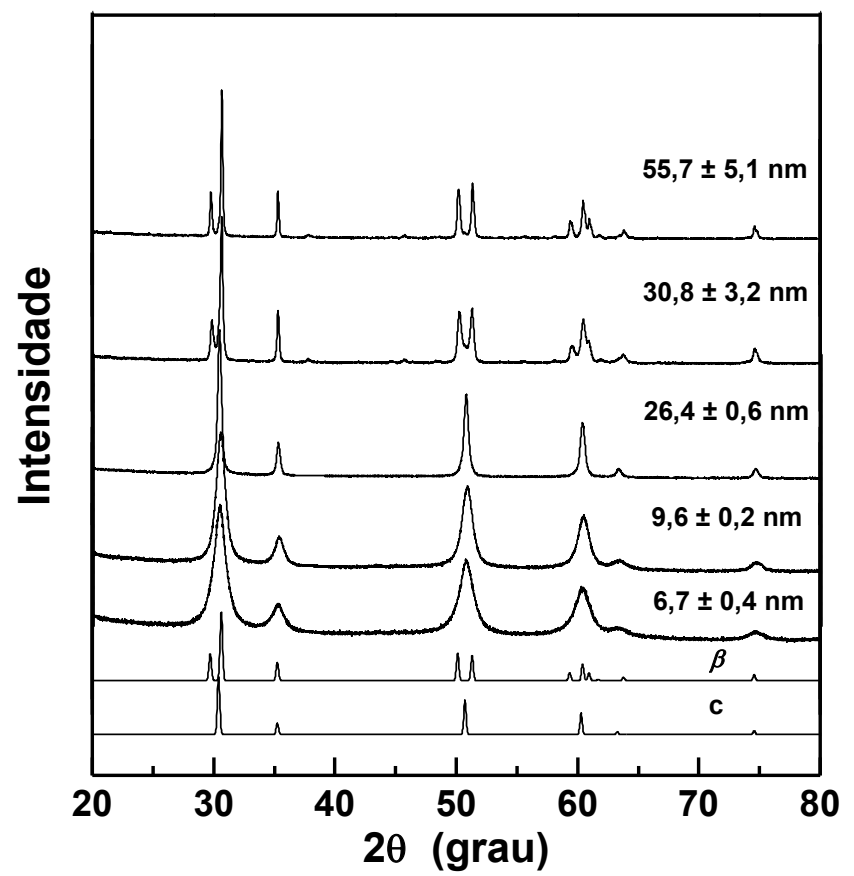

Figura 25. Difratogramas de raios $X$ de nanopartículas de 11.6ScSZ.

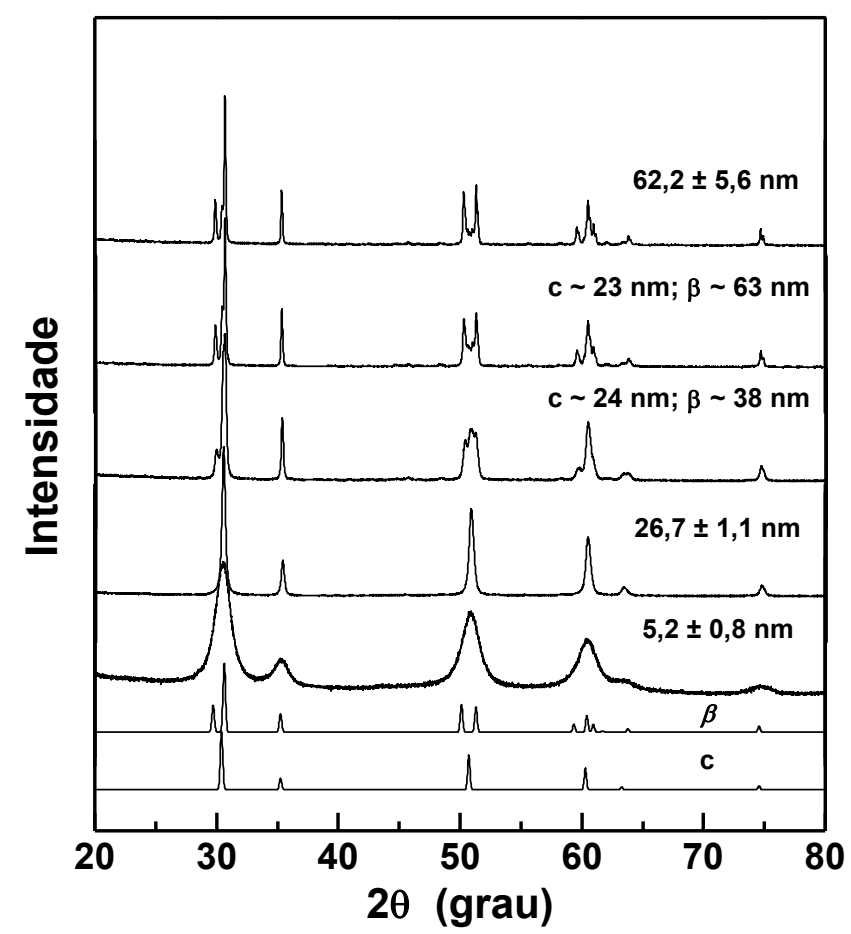

Figura 26. Difratogramas de raios $X$ de nanopartículas de 12.9ScSZ.

Por fim, a estrutura romboédrica $\gamma$ foi detectada nas composições com maiores teores de $\mathrm{Sc}_{2} \mathrm{O}_{3} \quad(13,6 ; 14,3$ e 19,3\%) como evidenciado nas Figuras 27-29. As fichas PDF 61-7752 e 64-9607 das fases romboédrica $(\gamma)$ e cúbica $(c)$, respectivamente, estão indicadas na parte inferior das Figuras. 


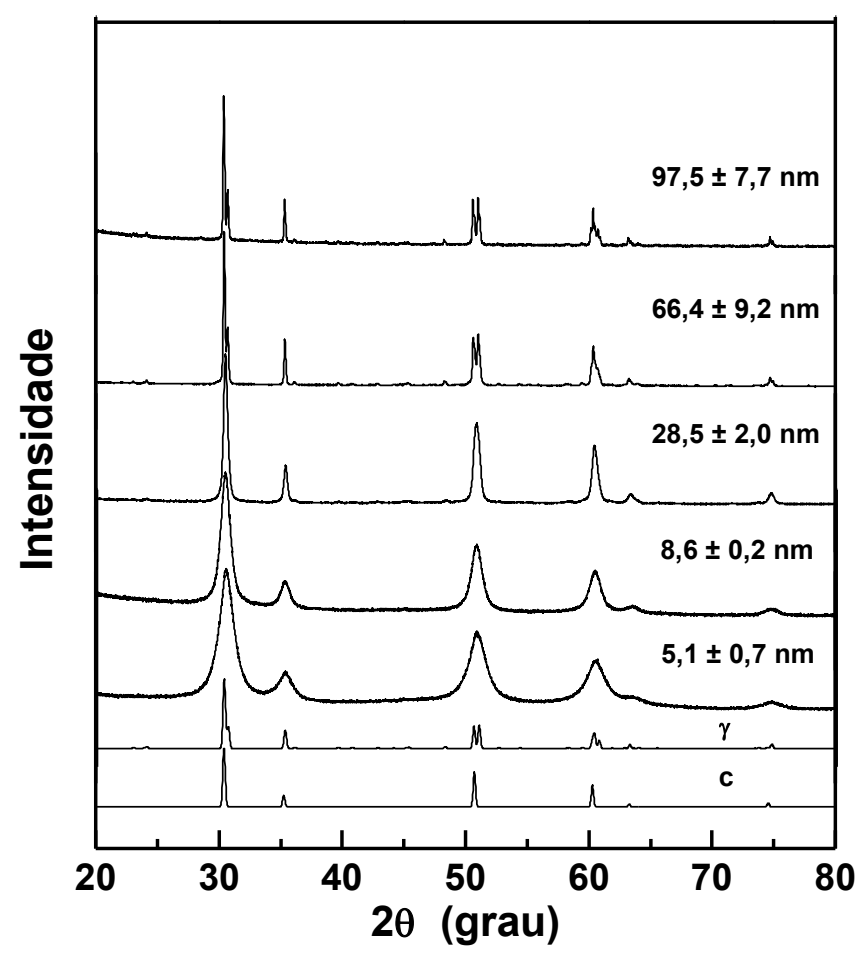

Figura 27. Difratogramas de raios $X$ de nanopartículas de 13.6ScSZ.

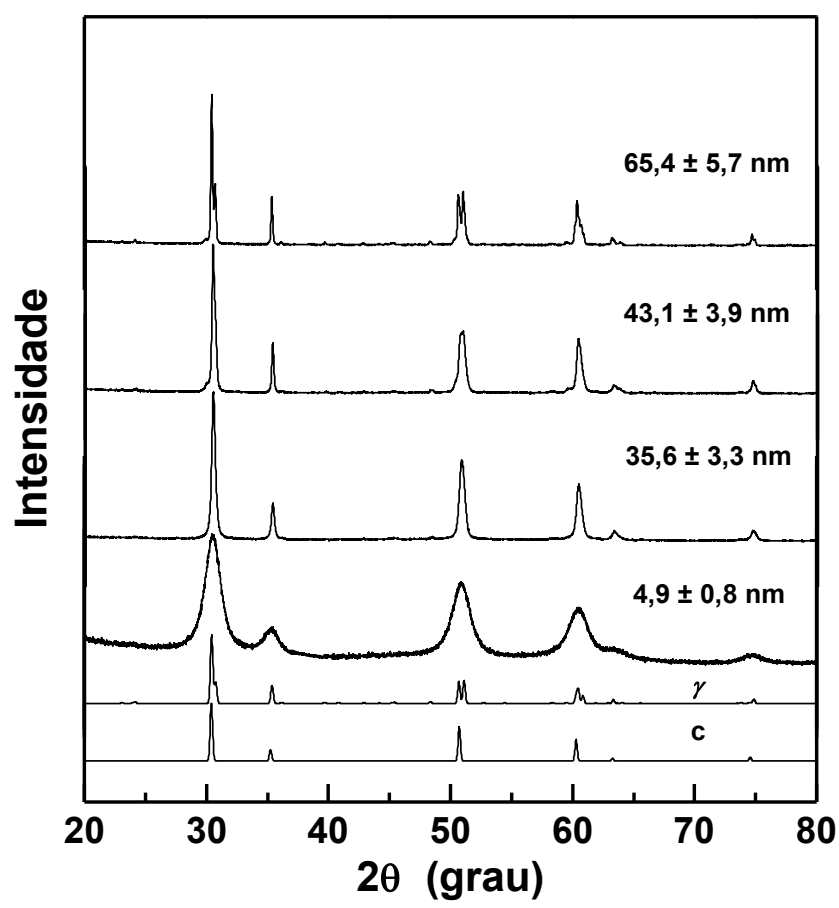

Figura 28. Difratogramas de raios X de nanopartículas de 14.3ScSZ. 


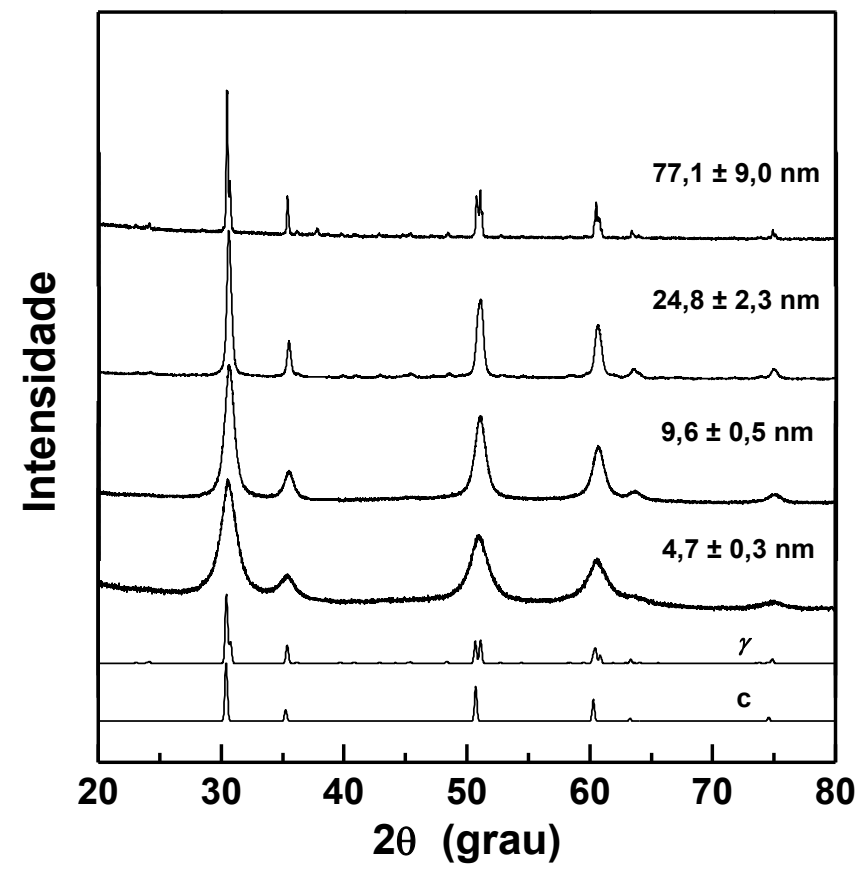

Figura 29. Difratogramas de raios $X$ de nanopartículas de 19.3ScSZ.

Conforme observado a partir dos difratogramas de raios $\mathrm{X}$, a estabilização da fase cúbica foi obtida em uma ampla faixa de concentração de escândia. Contudo, de acordo com o diagrama de fases de ScSZ, nenhuma das composições investigadas deveria apresentar a estrutura cúbica em condições ambientes. Dessa forma, é possível perceber que existe uma forte dependência do tamanho das partículas na estabilidade de fases do sistema zircônia-escândia.

Com o objetivo de tornar mais evidente as diferenças entre os polimorfos $c$ e $t$ em materiais à base de zircônia, a tetragonalidade (relação c/a') das nanopartículas pode ser avaliada..$^{33,74,75}$ Os parâmetros de rede determinados para todas as amostras com tamanho médio de partículas inferiores a $10 \mathrm{~nm}$ utilizando a ficha PDF 51-1603 da fase tetragonal são sumarizados na Tabela VI. O aumento da concentração de escândia promoveu a contínua diminuição da relação c/a'. Esses resultados sugerem que amostras na faixa de 1,1 a 6,3\% de escândia possuem estrutura tetragonal. No entanto, para maiores concentrações, a tetragonalidade se aproxima de 1 , indicando que houve a estabilização da fase cúbica. 
Tabela VI. Parâmetros de rede de yScSz, com tamanho médio de partículas inferiores a $10 \mathrm{~nm}$, obtidos usando a ficha PDF 51-1603 da fase tetragonal.

\begin{tabular}{ccccc}
\hline $\mathbf{S c}_{\mathbf{2}} \mathbf{O}_{3}$ (\% molar) & $\mathbf{a}(\mathbf{A})$ & $\mathbf{c}(\AA)$ & $\mathbf{a}^{\prime}=\mathbf{a} \sqrt{\mathbf{2}}(\AA \mathbf{\AA})$ & $\mathbf{c} / \mathbf{a}^{\prime}$ \\
\hline 1,1 & 3,5979 & 5,1502 & 5,0882 & 1,012 \\
2,1 & 3,5958 & 5,1475 & 5,0852 & 1,012 \\
3,1 & 3,5961 & 5,1376 & 5,0857 & 1,010 \\
4,2 & 3,5949 & 5,1325 & 5,0840 & 1,010 \\
6,3 & 3,5968 & 5,1252 & 5,0866 & 1,008 \\
8,4 & 3,6019 & 5,0862 & 5,0939 & 0,998 \\
10,6 & 3,5997 & 5,0829 & 5,0907 & 0,998 \\
11,6 & 3,5974 & 5,0845 & 5,0875 & 0,999 \\
12,9 & 3,5959 & 5,0582 & 5,0854 & 0,995 \\
13,6 & 3,5914 & 5,0747 & 5,0790 & 0,999 \\
14,3 & 3,5874 & 5,0870 & 5,0733 & 1,003 \\
19,3 & 3,5824 & 5,0657 & 5,0663 & 1,000 \\
\hline
\end{tabular}

As mudanças nos parâmetros de rede, determinados usando a ficha PDF 64-9607 da fase cúbica, em função do teor de Sc na faixa de 8 a $20 \%$ em mol de escândia são apresentados na Figura 30 . Foram encontrados valores semelhantes aos calculados utilizando a ficha da fase tetragonal. A diminuição no parâmetro de rede com $\mathrm{O}$ aumento da concentração de $\mathrm{Sc}_{2} \mathrm{O}_{3}$ é observada. Esse comportamento é típico de soluções sólidas formadas pela adição de cátions de menores valências. ${ }^{76}$ No entanto, o raio iônico de $\operatorname{Sc}^{3+}(0,87 \AA)^{6}$ é ligeiramente maior que o raio do $\mathrm{Zr}^{4+}(0,84 \AA)^{6}$ com coordenação 8. Considerando somente o efeito do raio iônico, o parâmetro de rede deveria aumentar com o aumento do teor de Sc, como observado nas soluções sólidas de zircônia contendo $\mathrm{Y}^{3+}(1,019 \AA)$ e $\mathrm{Yb}^{3+}(0,985 \AA) .{ }^{77}$

O comportamento encontrado no sistema zircônia-escândia, pode estar associado à compactação estrutural devido ao aumento da concentração de vacâncias de oxigênio causando distorções nas subredes dos cátions e ânions e, consequentemente, diminuindo o parâmetro de rede. A proximidade dos raios

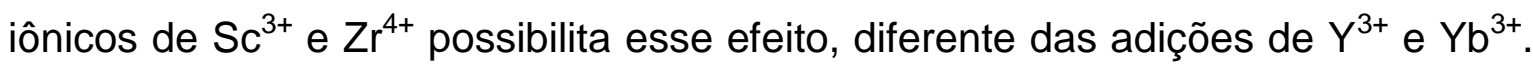
Esses resultados estão de acordo com estudos de simulação computacional, ${ }^{78}$ onde foi calculado que o número de coordenação médio de ambos os íons $\mathrm{Sc}^{3+} \mathrm{e}$ $\mathrm{Zr}^{4+}$ tende a diminuir com o aumento da concentração de Sc levando à diminuição do parâmetro de rede. 


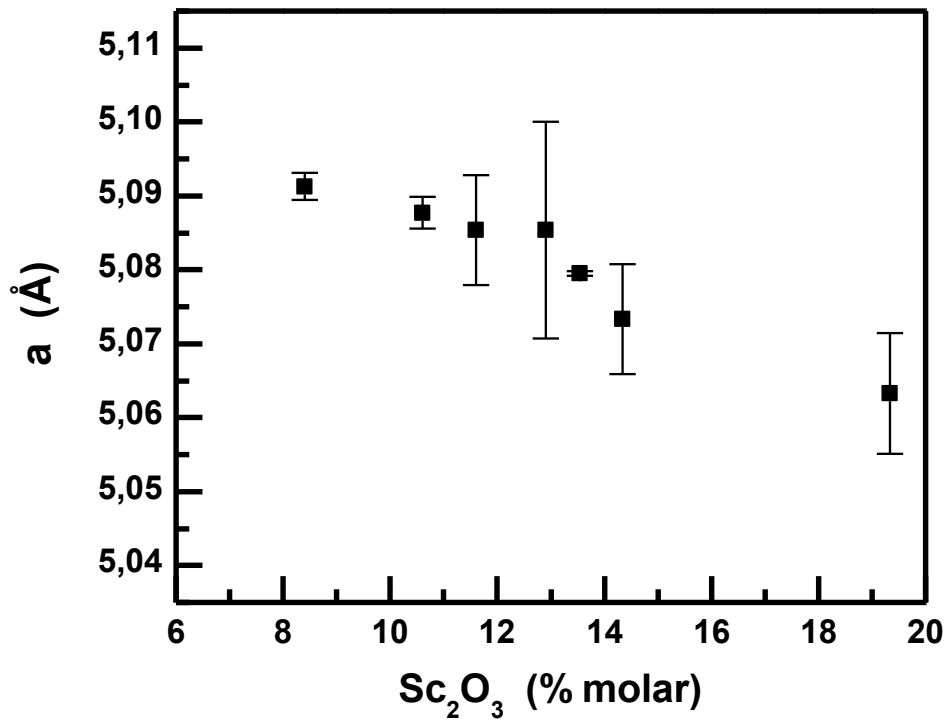

Figura 30. Parâmetro de rede das soluções sólidas de ScSZ em função da concentração de $\mathrm{Sc}_{2} \mathrm{O}_{3}$.

$\mathrm{O}$ aumento da concentração de $\mathrm{Sc}_{2} \mathrm{O}_{3}$ também promoveu a diminuição do tamanho de cristalito de amostras com estrutura cúbica, como pode ser observado na Figura 31 para nanopós calcinados a $500{ }^{\circ} \mathrm{C}$ por $2 \mathrm{~h}$. Por outro lado, nenhuma variação significativa de tamanho de cristalito foi detectada para os materiais com estrutura tetragonal.

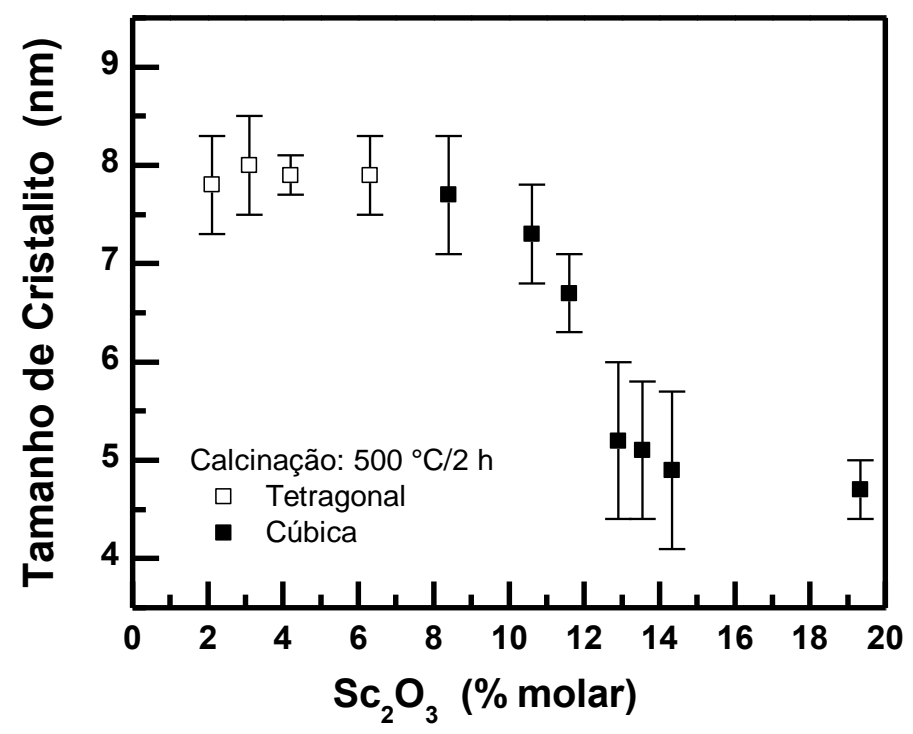

Figura 31. Tamanho médio de cristalito de $\mathrm{ScSZ}$ em função do teor de $\mathrm{Sc}_{2} \mathrm{O}_{3}$. 
As micrografias das amostras de 4.2ScSZ e $10.6 \mathrm{ScSZ}$ calcinadas a $500^{\circ} \mathrm{C}$ obtidas por microscópio eletrônico de transmissão são mostradas na Figura 32. Ambas as amostras consistem de pequenas partículas com formato esferoidal e tamanho de 7-8 nm. Observa-se que as nanopartículas estão aglomeradas. O tamanho das partículas está de acordo com o tamanho médio de cristalito encontrado por difração de raios X (Figura 21 e 24, respectivamente). Dessa forma, para o estudo termodinâmico da estabilidade de fases, foi assumido que o tamanho de cristalito é igual ao tamanho das partículas.
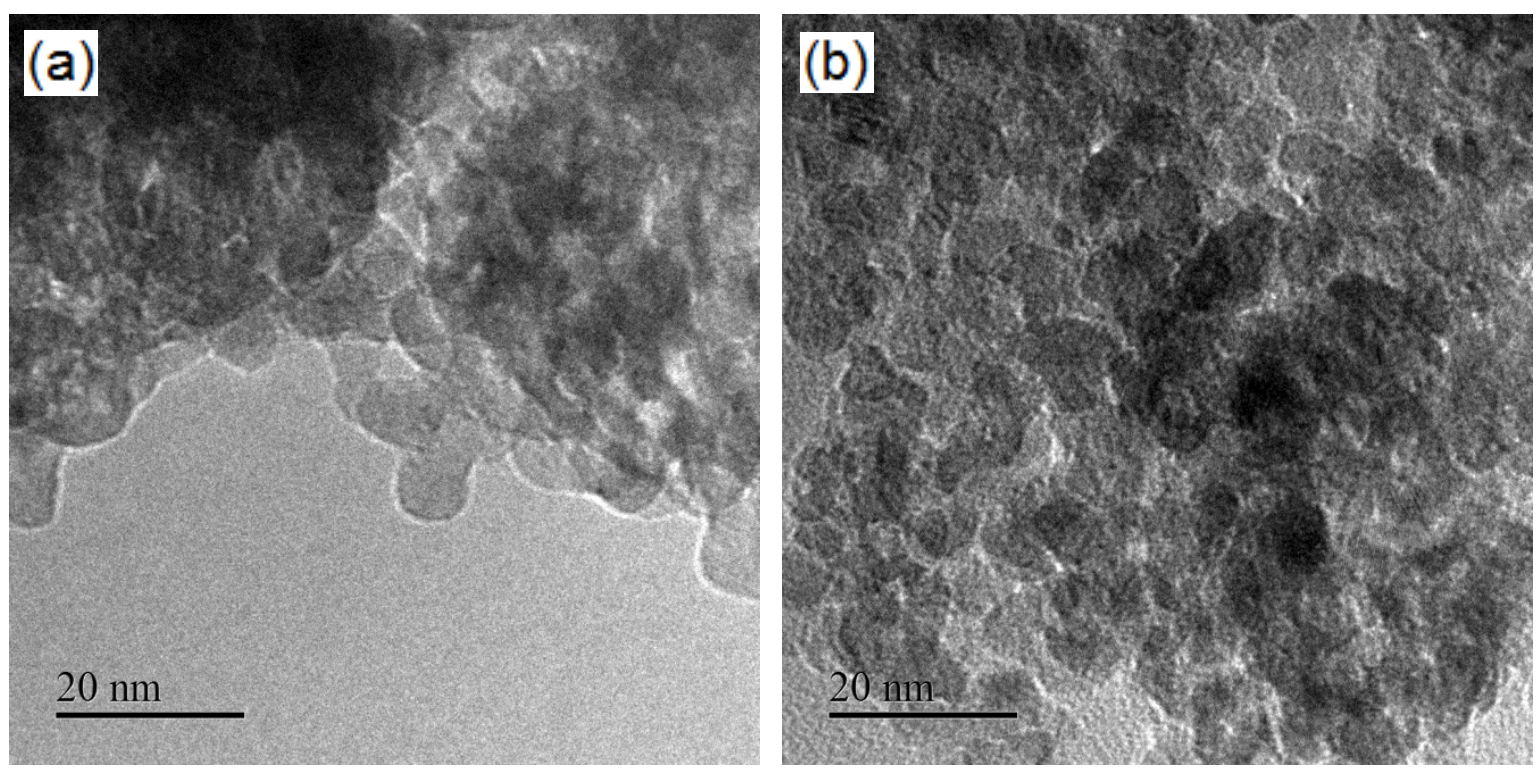

Figura 32. Micrografias dos pós de (a) 4.2ScSZ e (b) 10.6ScSZ calcinados a $500^{\circ} \mathrm{C}$ por $2 \mathrm{~h}$ obtidas por microscópio eletrônico de transmissão.

\section{Área de Superfície Específica}

A Tabela VII sumariza os valores experimentais de cada amostra de yScSZ estudada. Os resultados estão separados de acordo com a estrutura cristalina. Elevados valores de área de superfície específica $(A S)$ foram encontrados para pós com estrutura cúbica e tetragonal devido às baixas temperaturas de calcinação. O aumento do tamanho médio de partículas (d) promoveu a diminuição da área superficial, como esperado. 
Tabela VII. Valores experimentais encontrados para as amostras de yScSZ.

\begin{tabular}{|c|c|c|c|c|c|c|c|}
\hline $\begin{array}{c}\mathrm{Sc}_{2} \mathrm{O}_{3} \\
(\% \mathrm{~mol})\end{array}$ & $\begin{array}{c}\text { Calcinação } \\
\left({ }^{\circ} \mathrm{C} / \mathrm{h}\right)\end{array}$ & $\underset{(\mathrm{nm})}{d}$ & $\begin{array}{c}A S \\
\left(\mathrm{~m}^{2} / \mathrm{g}\right)\end{array}$ & $\begin{array}{c}\mathrm{H}_{2} \mathrm{O} \\
(\%)\end{array}$ & $\begin{array}{c}\Delta H_{\text {ads }} \\
(\mathrm{kJ} / \mathrm{mol})\end{array}$ & $\begin{array}{c}E S \\
\left(\mathrm{~J} / \mathrm{m}^{2}\right)\end{array}$ & $\begin{array}{c}\Delta H_{\mathrm{DS}} \\
(\mathrm{kJ} / \mathrm{mol})\end{array}$ \\
\hline \multicolumn{8}{|c|}{ Monoclínica } \\
\hline 0 & $1100 / 12$ & $31,5 \pm 1,8$ & 2,75 & 0 & $-60,5 \pm 1,5$ & $0,78 \pm 0,07$ & $19,5 \pm 0,3$ \\
\hline 1,1 & $1100 / 12$ & $30,4 \pm 1,4$ & 3,60 & 0,2 & $-60,7 \pm 1,3$ & $0,88 \pm 0,05$ & $16,9 \pm 1,3$ \\
\hline 2,1 & $1500 / 15$ & $33,0 \pm 1,9$ & - & 0 & & & $6,7 \pm 0,7$ \\
\hline \multicolumn{8}{|c|}{ Tetragonal } \\
\hline 1,1 & $450 / 0$ & $7,1 \pm 0,3$ & 139,1 & 7,4 & $-64,7 \pm 0,8$ & $0,85 \pm 0,02$ & $-6,6 \pm 1,3$ \\
\hline 2,1 & $500 / 2$ & $7,8 \pm 0,5$ & 117,6 & 6,5 & $-67,8 \pm 1,2$ & $0,87 \pm 0,05$ & $-11,6 \pm 1,5$ \\
\hline 3,1 & $500 / 2$ & $8,0 \pm 0,5$ & 114,5 & 7,1 & $-73,0 \pm 1,6$ & $0,85 \pm 0,04$ & $-14,9 \pm 2,0$ \\
\hline 4,2 & $500 / 2$ & $7,9 \pm 0,2$ & 124,7 & 6,1 & $-73,7 \pm 1,6$ & $0,88 \pm 0,04$ & $-7,5 \pm 2,1$ \\
\hline 6,3 & $500 / 2$ & $7,9 \pm 0,4$ & 119,7 & 6,2 & $-71,0 \pm 1,5$ & $0,83 \pm 0,04$ & $-3,3 \pm 1,2$ \\
\hline \multicolumn{8}{|c|}{ Cúbica } \\
\hline 8,4 & $500 / 2$ & $7,7 \pm 0,6$ & 120,3 & 10,6 & $-66,7 \pm 1,2$ & $0,81 \pm 0,04$ & $-8,3 \pm 0,3$ \\
\hline 10,6 & $500 / 2$ & $7,3 \pm 0,5$ & 120,6 & 7,0 & $-70,5 \pm 1,5$ & $0,75 \pm 0,04$ & $-16,1 \pm 1,8$ \\
\hline 11,6 & $500 / 2$ & $6,7 \pm 0,4$ & 139,7 & 7,2 & $-69,3 \pm 1,6$ & $0,76 \pm 0,04$ & $-14,1 \pm 2,2$ \\
\hline 12,9 & $500 / 2$ & $5,2 \pm 0,8$ & 145,6 & 8,8 & $-64,0 \pm 1,0$ & $0,74 \pm 0,03$ & $-23,5 \pm 1,2$ \\
\hline 13,6 & $500 / 2$ & $5,1 \pm 0,7$ & 150,2 & 7,8 & $-65,6 \pm 1,3$ & $0,73 \pm 0,03$ & $-21,1 \pm 1,5$ \\
\hline 14,3 & $500 / 2$ & $4,9 \pm 0,8$ & 147,1 & 7,4 & $-67,2 \pm 1,1$ & $0,78 \pm 0,03$ & - \\
\hline 19,3 & $500 / 2$ & $4,7 \pm 0,3$ & 143,9 & 8,3 & $-69,9 \pm 1,5$ & & $-31,8 \pm 2,0$ \\
\hline \multicolumn{8}{|c|}{ Romboédrica $\beta$} \\
\hline 10,6 & $1150 / 12$ & $50,5 \pm 4,6$ & 1,25 & 0 & - & $3,35 \pm 0,30^{*}$ & $-2,3 \pm 1,2$ \\
\hline 11,6 & $1000 / 10$ & $30,8 \pm 3,2$ & 2,29 & 0 & - & $4,35 \pm 0,35^{*}$ & $2,0 \pm 2,5$ \\
\hline 12,9 & $1300 / 24$ & $62,2 \pm 5,6$ & 0,34 & 0 & - & $4,40 \pm 0,32^{*}$ & $-3,9 \pm 0,2$ \\
\hline \multicolumn{8}{|c|}{ Romboédrica $\gamma$} \\
\hline 13,6 & $900 / 2$ & $28,5 \pm 2,0$ & 16,34 & 0,8 & - & $2,36 \pm 0,30^{*}$ & $-2,5 \pm 1,0$ \\
\hline 14,3 & $900 / 2$ & $35,6 \pm 3,3$ & 4,72 & 0 & - & $2,36 \pm 0,30^{*}$ & $-4,3 \pm 2,5$ \\
\hline 19,3 & $900 / 2$ & $24,8 \pm 2,3$ & 19,05 & 0,8 & - & $2,51 \pm 0,25^{*}$ & $-7,7 \pm 1,0$ \\
\hline \multicolumn{8}{|c|}{$\begin{array}{l}{ }^{*} \text { Calculado a partir da tendência linear da entalpia de dissolução em função da área superficial. } \\
d=\text { tamanho de cristalito } \\
A S=\text { área de superfície específica } \\
\mathrm{H}_{2} \mathrm{O}=\text { teor em massa de água }\end{array}$} \\
\hline
\end{tabular}




\section{Energia de Superfície}

Com o objetivo de determinar a energia de superfície das partículas sintetizadas de ScSZ, experimentos de microcalorimetria de adsorção de água foram realizados. A Figura 33 mostra os resultados de adsorção de água e sua entalpia obtidos para todos os pós de ScSZ estudados. Todas as amostras apresentaram o mesmo comportamento independente da estrutura e tamanho de cristalito.

A isoterma de adsorção de água (Figura 33a) consiste de três estágios bem definidos. Inicialmente, há um rápido aumento do teor de água adsorvida, a baixas pressões $(<0,02)$, o qual é atribuído à alta reatividade da superfície anidra das partículas. Em seguida há uma inclinação menos acentuada para pressões relativas de até 0,4. Novamente há um aumento, no terceiro estágio, até o limite do equipamento, a uma pressão relativa de 0,72. Perfil similar tem sido recentemente reportado para outros óxidos. ${ }^{33,63-65,79}$

A entalpia de adsorção em função da cobertura de água é apresentada na Figura 33b. Os resultados para todos os polimorfos são muito similares e, portanto, indicam a confiabilidade do método. Todas as curvas apresentaram valores altamente exotérmicos a baixas coberturas de água. A entalpia tornou-se gradualmente menos exotérmica com o aumento das camadas de água até a saturação das nanopartículas, atingindo um valor de $-44 \mathrm{~kJ} / \mathrm{mol}$ (linha pontilhada), que corresponde à entalpia de condensação da água. Esse comportamento está de acordo com o reportado para outros materiais. ${ }^{65,79}$

É interessante notar que, embora as curvas para todas as composições e polimorfos investigados terem apresentado perfis muito similares, foram encontradas diferenças nos valores absolutos e nas inclinações. As diferenças não são muito claras devido à sobreposição das curvas. 

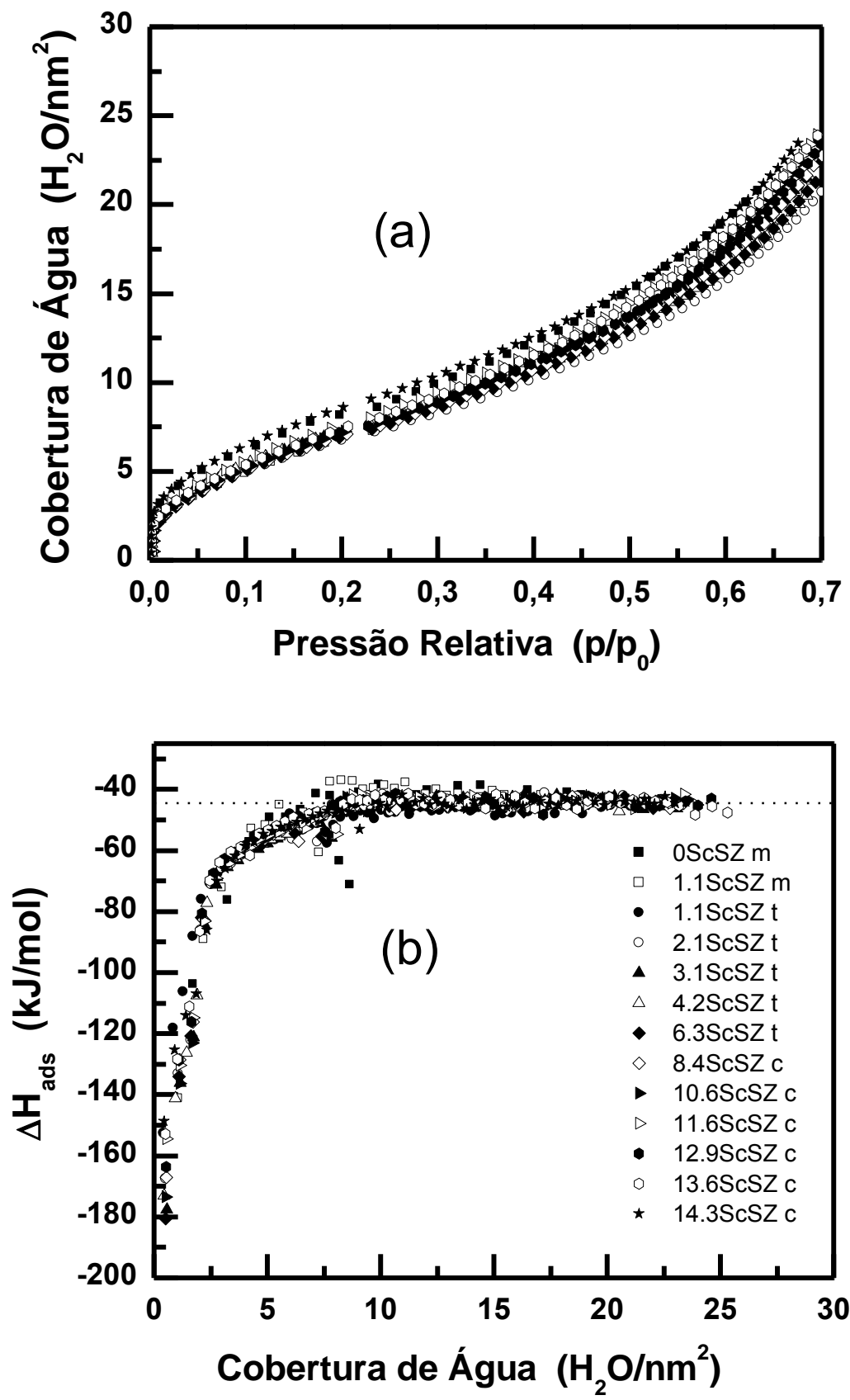

Figura 33. Curvas de microcalorimetria de adsorção de água obtidas para as nanopartículas de ScSZ com estruturas monoclínica, tetragonal e cúbica. (a) Isoterma de cobertura de água em função da pressão relativa. (b) Entalpia de adsorção em função da cobertura de água. 
As energias de superfície de nanopartículas anidras de ScSZ foram determinadas a partir dos experimentos de microcalorimetria de adsorção de água. A energia de superfície da maior parte das amostras foi calculada usando uma função de MATLAB 2010a personalizada onde os dados experimentais foram ajustados usando equações previamente detalhadas. ${ }^{65}$ Foi demonstrado bom acordo entre dados experimentais e ajustes teóricos para vários materiais. Os valores de energia de superfície para todos os polimorfos estudados são sumarizados na Tabela VII.

Os experimentos de microcalorimetria requerem cerca de $2 \mathrm{~m}^{2}$ de nanopartículas $(d<20 \mathrm{~nm})$ com elevadas áreas superficiais $\left(>100 \mathrm{~m}^{2} / \mathrm{g}\right)$. Como exemplo, para a amostra $8.4 \mathrm{ScSZ}$ cúbica, a área de $2 \mathrm{~m}^{2}$ corresponde a 16,6 mg de partículas anidras. Essa massa ocupa apenas o fundo do tubo do tipo garfo de duas pontas. Considerando que, quanto maior o tamanho das partículas, maior será a quantidade de material considerada adequada para esse tipo de medida, são necessários $424 \mathrm{mg}$ de pó para obter $2 \mathrm{~m}^{2}$ de $14.3 \mathrm{ScSZ}$ com estrutura romboédrica $\gamma(d=35,6 \mathrm{~nm})$. Enquanto que, para a amostra de $10.6 \mathrm{ScSZ}$ com fase $\beta,(d=50,5 \mathrm{~nm})$, são necessários $1600 \mathrm{mg}$. O tubo tipo garfo não possui capacidade para suportar essa quantidade de material.

Quando elevada quantidade de material é introduzido no tubo tipo garfo, as partículas ficam localizadas ao longo do tubo e quantidade substancial de pó permanece acima das termopilhas (Figura 13). Dessa forma, uma parte considerável da entalpia de adsorção não é detectada. Portanto, embora tenha sido comprovado que a microcalorimetria de adsorção de água é uma técnica eficaz para determinação de energia de superfície de nanopartículas de uma ampla variedade de óxidos, a medida de pós com pequenas áreas de superfície específica (tamanho médio de grãos relativamente elevado) representa uma importante limitação experimental do método.

Dessa forma, devido a essas limitações, uma metodologia alternativa foi utilizada para a determinação das energias de superfície de amostras com estruturas $\beta$ e $\gamma$. Os valores foram determinados a partir do coeficiente angular das curvas de entalpia de dissolução em função da área superficial, de acordo com a seguinte relação: ${ }^{80,81}$ 


$$
\Delta H_{\mathrm{DS}, \text { nano }}=\Delta H_{\mathrm{DS}}-E S^{\star} A S
$$

onde $\Delta H_{\mathrm{DS} \text {,nano }}$ é a entalpia de dissolução de nanopartículas e $\Delta H_{\mathrm{DS}}$ é a entalpia de dissolução do material, em $\mathrm{kJ} / \mathrm{mol}$, ES é a energia de superfície, em $\mathrm{J} / \mathrm{m}^{2}$, e AS é a área superficial, em $\mathrm{m}^{2} / \mathrm{mol}$.

Dessa forma, as curvas de cada material com fase cúbica foram obtidas combinando as energias de superfície, obtidas por microcalorimetria de adsorção de água, com as entalpias de dissolução (Tabela VII) obtidas por calorimetria à alta temperatura. Assim, as ES das amostras romboédricas foram determinadas considerando $A S$ para cada transição de fase $c-\beta$ e $c-\gamma$ calculada de acordo com o tamanho médio de partículas estimado com base nos resultados de difração de raios X. Os valores usados para cálculo de ES são mostrados na Tabela VIII. Essa metodologia tem sido empregada para calcular energias de superfície de diversos óxidos. ${ }^{80,81}$

Tabela VIII. Tamanho médio de partículas (d), área superficial específica $(A S)$ e entalpia de dissolução ( $\Delta H_{\mathrm{DS}}$, nano) das transições de fase $c-\beta$ e $c-\gamma$ usadas para cálculo das energias de superfície das amostras com estrutura romboédrica.

\begin{tabular}{cccc}
\hline $\mathbf{S c}_{2} \mathbf{O}_{3}$ (\% molar) & $\boldsymbol{d}(\mathbf{n m})$ & $\boldsymbol{A S}\left(\mathbf{m}^{2} / \mathbf{m o l}\right)$ & $\Delta \boldsymbol{H}_{\mathrm{DS}, \text { nano }}(\mathbf{k J} / \mathbf{m o l})$ \\
\hline \multicolumn{4}{c}{ Transição de fase $c-\beta$} \\
11,6 & 27 & $\sim 4400$ & -17 \\
12,9 & 27 & $\sim 4400$ & -20 \\
\hline \multicolumn{4}{c}{ Transição de fase $c-\gamma$} \\
13,6 & 27 & $\sim 9100$ & -23 \\
14,3 & 13 & $\sim 1200$ & -28 \\
19,3 & 10 & $\sim 1450$ & -33 \\
\hline
\end{tabular}


Contudo, cabe ressaltar que, os valores de tamanho médio de partículas e área superficial das amostras com fases $\beta$ e $\gamma$ são semelhantes aos encontrados para soluções sólidas com estrutura monoclínica (Tabela VII), o que torna possível a utilização da técnica de microcalorimetria para determinação de ES. No entanto, a metodologia que utiliza a entalpia de dissolução foi aplicada para todas as amostras $\beta$ e $\gamma$ de modo a manter o mesmo procedimento para a estrutura romboédrica.

Os valores de energia de superfície em função da concentração de $\mathrm{Sc}_{2} \mathrm{O}_{3}$ dos cinco polimorfos são mostrados na Figura 34. A curva que melhor se ajusta aos dados experimentais de cada polimorfo foi obtida pelo programa computacional Origin 8.0. Valores semelhantes foram encontrados para as fases monoclínica, tetragonal e cúbica. A proximidade nas energias de superfície para $c$ e $t$ podem ajudar a compreender a formação da fase tetragonal $t^{\prime}$ na matriz cúbica, a qual foi reportada para o $8 \mathrm{ScSZ}$ durante envelhecimento térmico provocando a diminuição da condutividade iônica. ${ }^{18}$ Dessa forma, as similaridades entre os dados sugerem que a transição de fase $c-t$ é um processo termodinamicamente favorável. Assim como é difícil diferenciar as fases com estrutura tetragonal $\left(t, t^{\prime}\right.$ e $\left.t^{\prime \prime}\right)$ por difração de raios $\mathrm{X}$, não foi possível diferenciar esses polimorfos em termos de energia de superfície.

Elevados valores obtidos para as fases $\beta$ e $\gamma$ podem estar associados à alta estabilidade desses materiais à temperatura ambiente de acordo com o diagrama de fases da zircônia-escândia previamente reportado. ${ }^{17}$ Esses resultados são consistentes com as diferentes simetrias estruturais, onde há uma tendência do polimorfo com maior simetria apresentar menor energia de superfície. Esses valores de energias de superfície para as estruturas monoclínica, tetragonal, cúbica e romboédrica $(\beta$ e $\gamma$ ) do sistema zircôniaescândia são inéditos. 


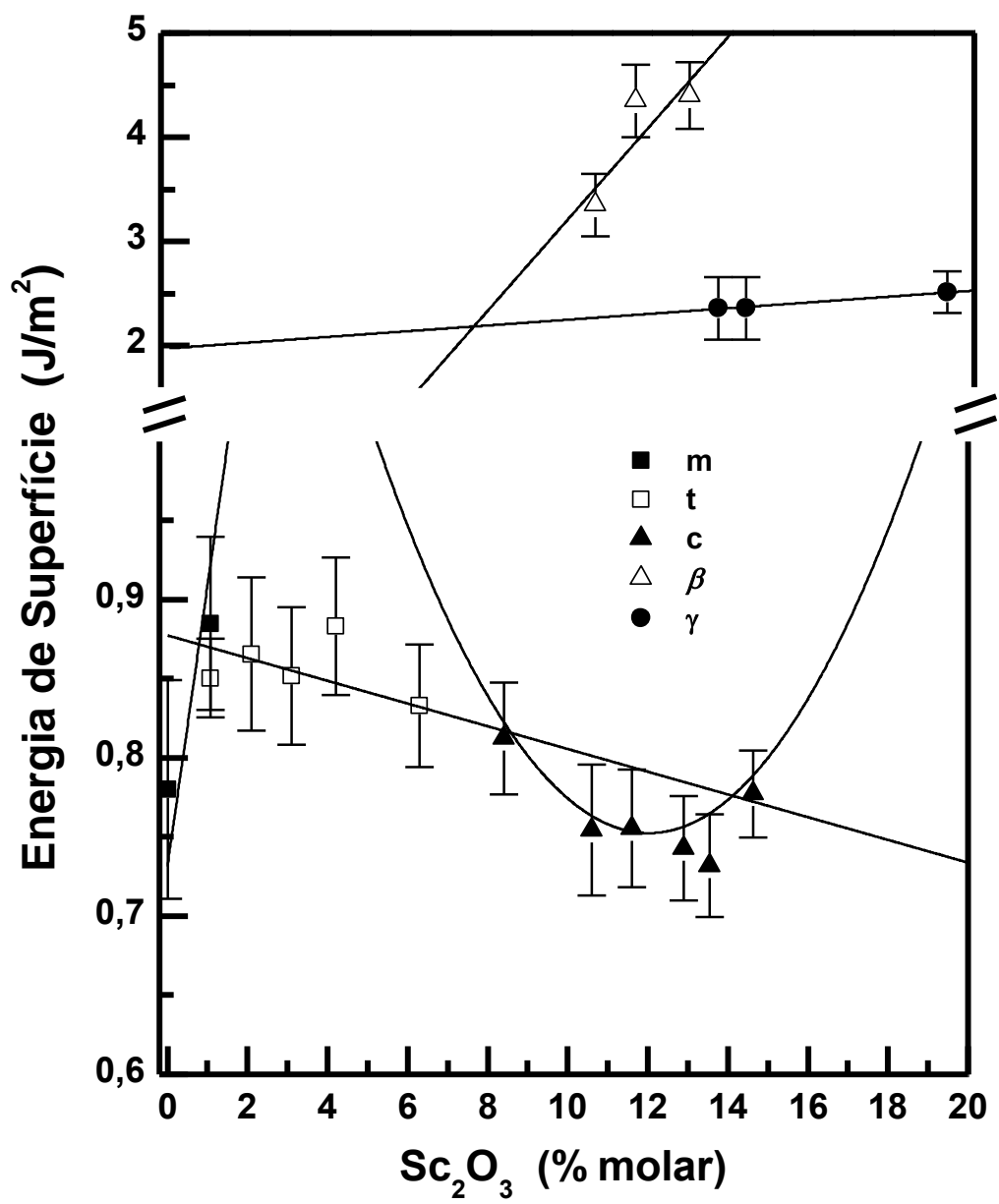

Figura 34. Valores de energia de superfície em função da concentração de $\mathrm{Sc}_{2} \mathrm{O}_{3}$ para cinco polimorfos do sistema zircônia-escândia.

As equações das curvas que melhor se ajustaram aos dados experimentais para cada polimorfo, em $\mathrm{J} / \mathrm{m}^{2}$, são apresentadas a seguir em função da concentração de $\mathrm{Sc}_{2} \mathrm{O}_{3}(y)$, em \% molar:

$$
\begin{aligned}
& E S_{m}=(0,732)+(0,177) y \\
& E S_{t}=(0,877)+(-0,00718) y \\
& E S_{c}=(1,130)+(-0,0567) y+(0,00212) y^{2} \\
& E S_{\beta}=(-1,153)+(0,440) y \\
& E S_{\gamma}=(1,973)+(0,0277) y
\end{aligned}
$$

Utilizando essas equações é possível calcular as energias de superfície para cada transição de fase em função da concentração de escândia. 


\section{Entalpia}

Para a obtenção do diagrama de fases em nanoescala, são necessários valores precisos de entalpia para cada polimorfo. Para essa finalidade, foi utilizada a entalpia de dissolução medida a partir da técnica de calorimetria de dissolução de óxidos à alta temperatura. Conforme descrito na seção experimental, os calores de dissolução de nanopartículas correspondem a diversos processos. A entalpia de dissolução de cada amostra estudada foi determinada combinando os resultados de termogravimetria, entalpia de adsorção de água e dados de área e energia de superfície (Tabela VII). O ciclo termoquímico usado para a correção da entalpia de dissolução é mostrado na Tabela IX, enquanto que, as entalpias de dissolução $\left(\Delta H_{\mathrm{DS}}\right)$ após as devidas correções são sumarizados na Tabela VII.

Tabela IX. Ciclo termoquímico usado para correção dos calores de dissolução obtidos experimentalmente.

\begin{tabular}{|c|c|}
\hline 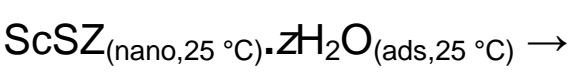 & $\Delta H_{1}=\Delta H_{\mathrm{DS}, \text { nano }}$ \\
\hline$z \mathrm{H}_{2} \mathrm{O}_{\left(1,25{ }^{\circ} \mathrm{C}\right)} \rightarrow z \mathrm{H}_{2} \mathrm{O}_{\left(\mathrm{g}, 700^{\circ} \mathrm{C}\right)}$ & $\Delta H_{2}=z(25,0 \pm 0,1) \mathrm{kJ} / \mathrm{mol}$ \\
\hline$z \mathrm{H}_{2} \mathrm{O}_{\left(\text {ads }, 25^{\circ} \mathrm{C}\right)} \rightarrow \mathrm{zH}_{2} \mathrm{O}_{\left(1,25^{\circ} \mathrm{C}\right)}$ & $\Delta H_{3}=-z \Delta H_{\mathrm{ads}}$ \\
\hline $\operatorname{ScSZ}_{\left(\text {nano }, 25^{\circ} \mathrm{C}\right)} \rightarrow \operatorname{ScSZ}_{\left(25^{\circ} \mathrm{C}\right)}$ & $\Delta H_{4}=-E S^{\star} A S$ \\
\hline $\operatorname{ScSZ}_{\left(25^{\circ} \mathrm{C}\right)} \rightarrow \operatorname{ScSZ}_{\left(\text {dissol }, 700^{\circ} \mathrm{C}\right)}$ & $\Delta H_{5}=\Delta H_{\mathrm{DS}}$ \\
\hline$\Delta H_{1}=\Delta H_{2}+\Delta H_{3}+\Delta H_{4}+\Delta H_{5}$ & \\
\hline
\end{tabular}

A entalpia de dissolução de 19,5 \pm 0,3 kJ/mol encontrada para a zircônia monoclínica pura está de acordo com o valor previamente reportado. ${ }^{72,82}$ Os calores de dissolução em função da concentração de $\mathrm{Sc}_{2} \mathrm{O}_{3}$ dos cinco polimorfos são mostrados na Figura 35. As entalpias medidas para o polimorfo tetragonal são menos endotérmicas que para a fase monoclínica. Isso indica a maior estabilidade da fase monoclínica em relação à tetragonal, o que é consistente com os difratogramas de raios $X$ de $1.1 \mathrm{ScSZ}$ e 2.1ScSZ (Figuras 18 e 19, respectivamente). 
As estruturas romboédricas apresentaram valores similares. No entanto, a curva da fase $\beta$ é melhor representada por uma parábola, enquanto que, uma função linear melhor se ajusta aos dados experimentais da fase $\gamma$. A função linear para a fase $\gamma$ está de acordo com o reportado na literatura. ${ }^{83}$ Com exceção da fase $\gamma$, as entalpias de dissolução para as estruturas monoclínica, tetragonal, cúbica e $\beta$ do sistema ScSZ estão sendo reportadas pela primeira vez.

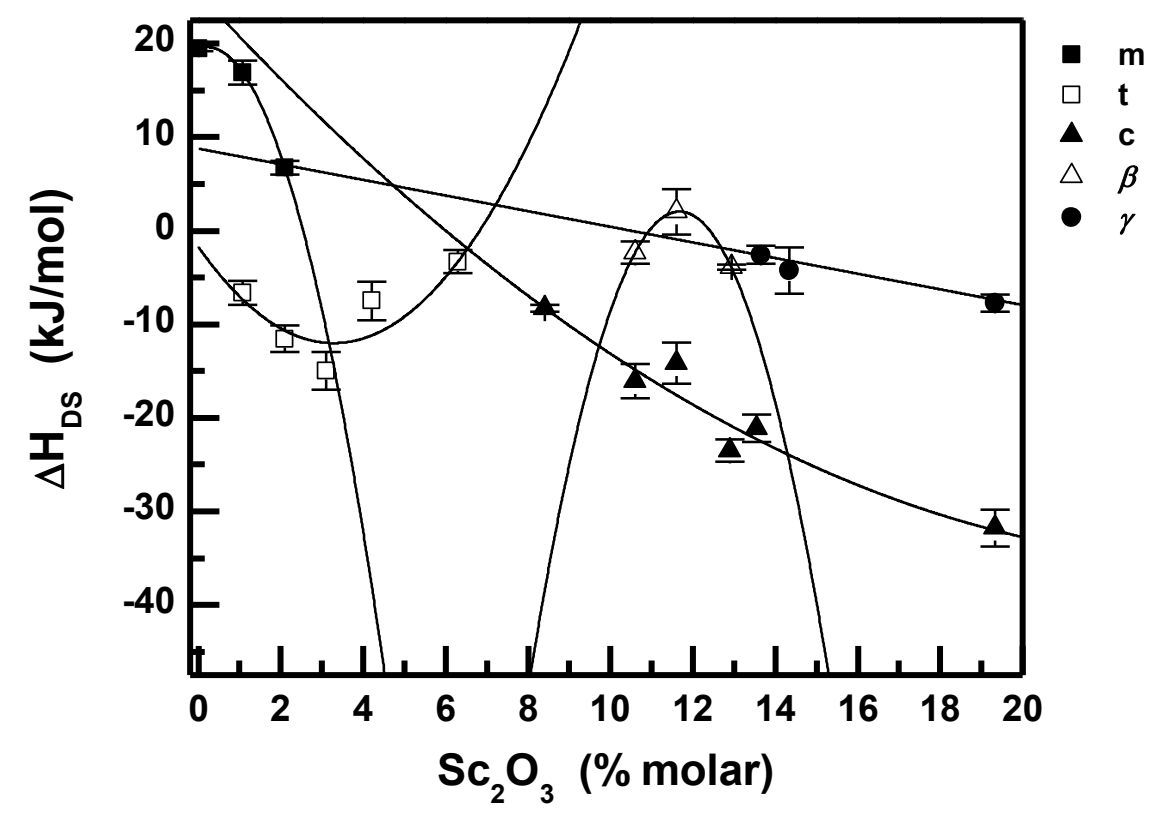

Figura 35. Entalpia de dissolução em função da concentração de $\mathrm{Sc}_{2} \mathrm{O}_{3}$ para cinco polimorfos do sistema zircônia-escândia.

As equações das curvas que melhor se ajustam aos valores experimentais para cada polimorfo, em $\mathrm{kJ} / \mathrm{mol}$, são mostrados a seguir em função da concentração de $\mathrm{Sc}_{2} \mathrm{O}_{3}(y)$, em \% molar:

$$
\begin{aligned}
& H_{m}=(19,48)+(1,495) y+(-3,603) y^{2} \\
& H_{t}=(-1,708)+(-6,279) y+(0,957) y^{2} \\
& H_{c}=(25,476)+(-4,814) y+(0,0951) y^{2} \\
& H_{\beta}=(-513,556)+(88,326) y+(-3,783) y^{2} \\
& H_{\gamma}=(8,784)+(-0,836) y
\end{aligned}
$$


Assim como os dados de energia de superfície, as equações encontradas para os valores experimentais de entalpia de dissolução podem ser usadas para determinar o calor de transição para as transformações de fase: $m \rightarrow t, c \rightarrow t$, $c \rightarrow \beta$ e c $\rightarrow \gamma$.

\section{Entropia}

A entropia é outra grandeza termodinâmica que deve ser considerada para a construção do diagrama de fases. A entropia de cada transformação de fase mencionada acima pode ser determinada usando valores experimentais de transição encontrados por Jacobson e colaboradores ${ }^{84}$ para a zircônia pura: $\Delta S_{m \rightarrow t}=4,10 \mathrm{~J} / \mathrm{K} . \mathrm{mol}$ e $\Delta S_{t \rightarrow c}=2,29 \mathrm{~J} / \mathrm{K} . \mathrm{mol}$. Os valores de entropia da transição cúbica-romboédrica foram reportados por Fujimori e colaboradores $\left(\Delta S_{C \rightarrow \beta}=1,23 \mathrm{~J} / \mathrm{K} . \mathrm{mol}\right)^{85}$ e Simoncic e Navrotsky $\left(\Delta S_{c \rightarrow \gamma}=1,36 \mathrm{~J} / \mathrm{K} . \mathrm{mol}\right){ }^{83}$

Considerando que a entropia de sólidos não varia excessivamente com a temperatura, esses dados são próximos aos valores à temperatura ambiente. Mudanças na entropia devido a variações da concentração de escândia foram calculadas pelo modelo de solução ideal, de acordo com a equação: ${ }^{33}$

$$
\Delta S_{\mathrm{Re} \text { gular }}=-R[y \ln (y)+(1-y) \ln (1-y)]
$$

onde y é a fração de $\mathrm{Sc}_{2} \mathrm{O}_{3}$ em \% molar e $R$ é a constante dos gases.

Embora a substituição de íons $\mathrm{Zr}^{4+}$ por $\mathrm{Sc}^{3+}$ promova distorções nas subredes devido ao aumento da concentração de vacâncias de oxigênio, conforme discutido anteriormente, a Eq.(24) não leva em consideração a associação de defeitos, os quais podem comprometer a aleatoriedade da mistura no sistema e, consequentemente, superestimar a entropia. No entanto, pelo fato da contribuição da entropia ser mínima, esses fatores não comprometem a tendência das curvas. Portanto, as considerações usadas nesse trabalho são consistentes e apropriadas para a determinação do diagrama de fases em nanoescala. 


\section{Diagrama de Fases}

O diagrama de fases que correlaciona tamanho de partículas e composição, determinado com base em dados termodinâmicos à temperatura ambiente, para o sistema zircônia-escândia é apresentado na Figura 36. As curvas no diagrama foram calculadas de acordo com a Eq.(7). Cada região corresponde ao intervalo no qual cada polimorfo é termodinamicamente estável.

O eixo das ordenadas está em escala logarítmica decimal para facilitar a observação em várias ordens de grandeza de tamanho de partículas. Embora materiais amorfos $(A)$ não tenham sido estudados nesse trabalho, a linha tracejada representa o possível limite para a transição amorfo-cristalino, o qual foi estimado com base no parâmetro de rede do polimorfo cúbico. No entanto, tamanhos de partícula próximos a 0,1 nm são impraticáveis para materiais à base de $\mathrm{ZrO}_{2}$, uma vez que o raio iônico do oxigênio é igual a 0,142 nm. Dessa forma, a faixa denominada de amorfo pode ser atribuída à região na qual há duas possibilidades, amorfo ou sem significado físico. Considerando que o diagrama de fases em nanoescala foi determinado para aplicações em condições ambientes, as variações em função da temperatura não foram consideradas.

Resultados obtidos para a zircônia pura sugerem que é possível a estabilização da fase monoclínica abaixo de aproximadamente $5 \mathrm{~nm}$, de acordo com os diagramas de fases em escala nanométrica recentemente publicados para zircônia-ítra ${ }^{33}$ e zircônia-cálcia. ${ }^{34} \mathrm{O}$ diagrama de fase é muito consistente com os resultados de difração de raios $\mathrm{X}$. A transição de fase tetragonal-monoclínica para o 2.1ScSZ, por exemplo, ocorreu para tamanho médio de partículas de aproximadamente $25 \mathrm{~nm}$ (Figura 19). A transição $c-\beta$ foi estimada em $27 \mathrm{~nm}$ (Tabela VIII) para os teores de 10,6; 11,6 e 12,9\% de escândia. O comportamento encontrado para a transformação $c-\gamma$, uma reta com coeficiente angular negativo, está de acordo com os resultados da Tabela VIII. Houve bom acordo com trabalhos recentemente reportados para nanocerâmicas de zircôniaescândia. ${ }^{15,35,73}$ Além disso, os resultados apresentados indicam que ambos os métodos utilizados para a determinação das energias de superfície são adequados para esse tipo de material. 
É importante ressaltar que, o gráfico obtido em nanoescala não tem como objetivo descartar o diagrama de fase de temperatura-composição de ScSZ. Esses resultados mostram que a estabilidade de fases de nanomateriais deve ser levada em consideração em termos de aplicação.

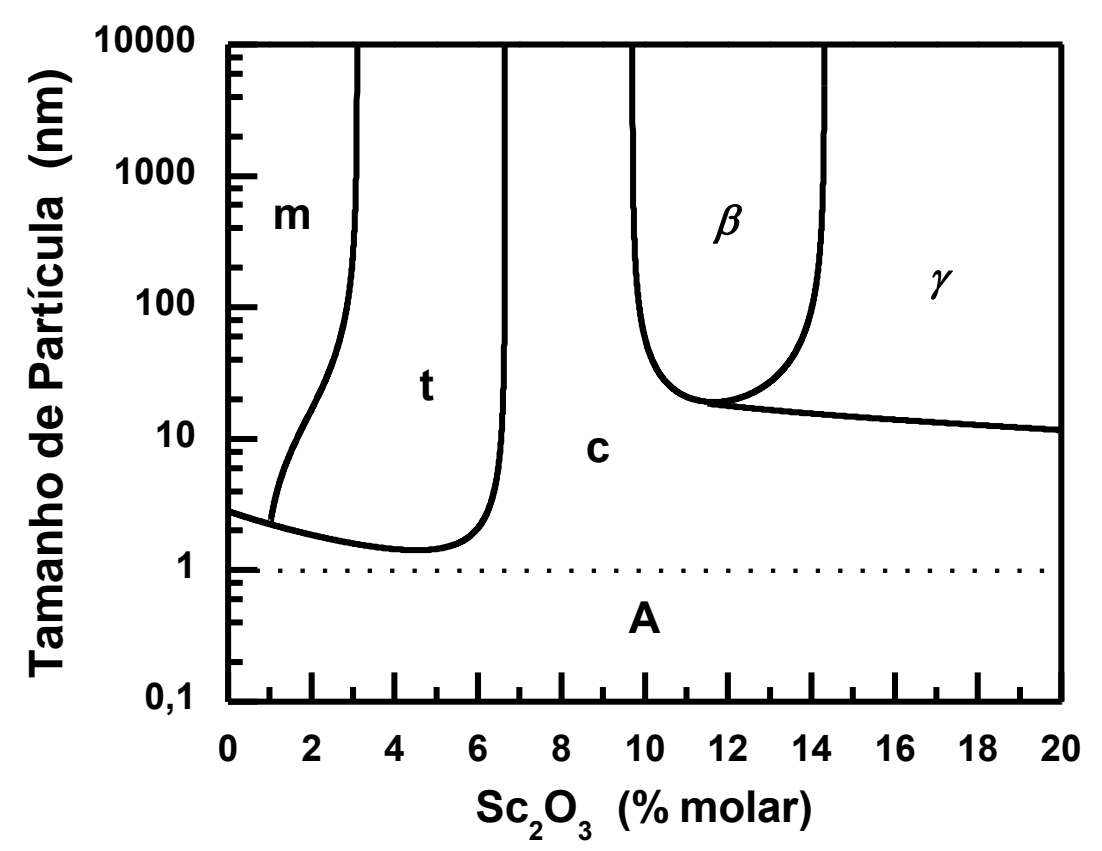

Figura 36. Diagrama de fases de tamanho de partícula-composição para o sistema zircônia-escândia. Amorfo $(A)$, monoclínica $(m)$, tetragonal $(t)$, cúbica $(c)$, romboédrica $(\beta$ e $\gamma)$.

Zircônia-Escândia Contendo Aditivos

O rendimento, calculado pela equação de formação de cada composição, obtido a partir das sínteses pelo método de coprecipitação de hidróxidos foi superior a $95 \%$ para todas as composições estudadas. 


\section{Caracterização dos Pós}

Na Figura 37 são mostradas as curvas TG e DTA do pó precursor de 10Sc1DySZ, obtidas sob atmosfera dinâmica de ar sintético durante aquecimento. A perda de massa chegou a $36 \%$ e ocorreu até cerca de $510{ }^{\circ} \mathrm{C}$, como pode ser observado na curva TG.

De acordo com a equação de formação da solução sólida:

$$
\left(\mathrm{Sc}_{0,18} \mathrm{Dy}_{0,02} \mathrm{Zr}_{0,8}\right)(\mathrm{OH})_{3,8} \rightarrow \mathrm{Sc}_{0,18} \mathrm{Dy}_{0,02} \mathrm{Zr}_{0,8} \mathrm{O}_{1,9}+1,9 \mathrm{H}_{2} \mathrm{O}
$$

a perda de massa teórica é de aproximadamente $23 \%$.

De modo geral, elevados valores de perda de massa comparados aos valores teóricos são observados em sínteses de materiais à base de $\mathrm{ZrO}_{2}$ por via úmida. Recentemente, a perda de massa encontrada para o precursor de $\mathrm{ZrO}_{2}$, obtido a partir da hidrólise de oxicloreto de zircônio na presença de acetato de sódio, foi de $44,1 \%{ }^{86}$ A diferença entre a perda de massa teórica e experimental foi atribuída à água e compostos orgânicos residuais.

De acordo com os resultados de microcalorimetria de adsorção de água (Tabela VII), as nanopartículas de ScSZ têm elevada capacidade de adsorção. Dessa forma, a diferença entre os valores teórico e experimental pode ser atribuída a moléculas de água e álcool isopropílico que foram adsorvidas na superfície das partículas durante o processo de lavagem.

De acordo com a curva TG, abaixo de $200^{\circ} \mathrm{C}$ ocorre evaporação parcial de água e álcool, evidenciada pelo pico endotérmico em $127^{\circ} \mathrm{C}$ na curva DTA, com início ( $\mathrm{T}_{\text {onset }}$ ) a $65^{\circ} \mathrm{C}$. A presença de água em materiais à base de $\mathrm{ZrO}_{2}$ é indesejável, pois pode prejudicar o processo de densificação. Isso porque essas moléculas de hidratação nos precipitados promovem a formação de aglomerados densos que não se desintegram durante a compactação e impedem a densificação até mesmo em temperaturas superiores a $1600{ }^{\circ} \mathrm{C} .{ }^{32}$ 


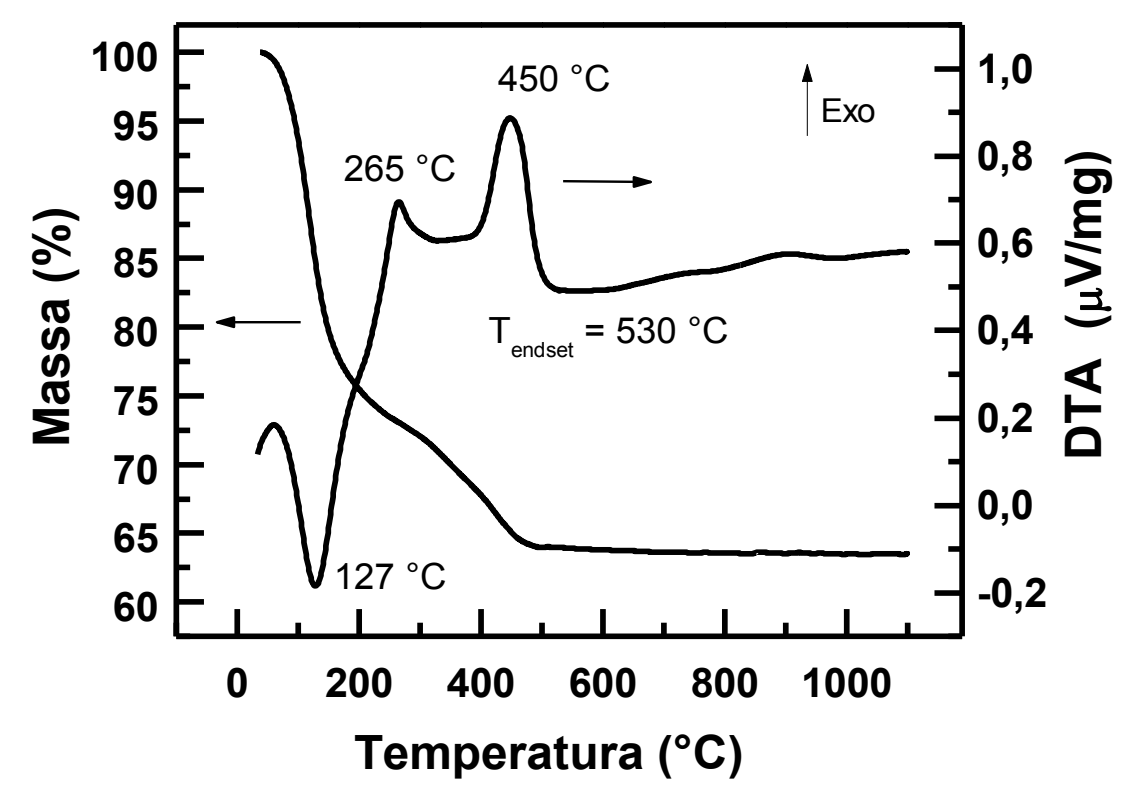

Figura 37. Curvas TG e DTA, obtidas sob atmosfera dinâmica de ar sintético com razão de aquecimento de $10{ }^{\circ} \mathrm{C} / \mathrm{min}$, do precursor de $10 \mathrm{Sc} 1 \mathrm{DySZ}$ sintetizado por coprecipitação.

$\mathrm{Na}$ faixa de temperatura entre 200 e $400{ }^{\circ} \mathrm{C}$ ocorre decomposição do hidróxido, a qual é acompanhada pela reação de combustão de álcool. ${ }^{26}$ Esses processos são evidenciados pelo pico exotérmico a $265^{\circ} \mathrm{C}$ na curva DTA.

É conhecido que a temperatura de cristalização de zircônia pura sintetizada por coprecipitação em hidróxido de amônio é de $447{ }^{\circ} \mathrm{C} .{ }^{87}$ Assim, o segundo pico exotérmico a $450^{\circ} \mathrm{C}$ é associado ao processo de cristalização da solução sólida acompanhado pela combustão de álcool residual. A ligeira perda de massa observada próximo a essa temperatura provavelmente está relacionada ao final da decomposição dos hidróxidos. Nenhum evento endo ou exotérmico foi identificado para temperaturas superiores a $530^{\circ} \mathrm{C}$.

Comportamento térmico semelhante ao mostrado na Figura 37 foi encontrado para as amostras de 10ScSZ contendo os diferentes tipos e teores de aditivos sintetizadas por via úmida. 
Para verificar a presença de álcool nos pós precursores sintetizados por via úmida foi realizada análise elementar para determinação de carbono, hidrogênio e nitrogênio. A Tabela $X$ lista os teores em massa desses elementos encontrados em amostras de 10Sc1NbSZ e 10Sc1DySZ. Foi encontrado um teor de carbono ligeiramente mais elevado em amostras contendo $\mathrm{Nb}$. Esse resultado será discutido a seguir. O teor residual de nitrogênio provavelmente é oriundo do hidróxido de amônio, o qual foi utilizado como agente precipitante. Esses resultados confirmam a presença de carbono e hidrogênio, os quais são atribuídos às moléculas de álcool adsorvidas nas superfícies dos pós precursores, o que corrobora a discussão dos resultados de análise térmica. Além disso, a soma da perda de massa teórica com a massa de carbono representa cerca de $30 \%$ nos precursores, valor próximo ao obtido pela curva TG.

Tabela X. Porcentagens em massa de carbono, hidrogênio e nitrogênio nos pós precursores de 10ScSZ contendo aditivos sintetizados por coprecipitação de hidróxidos.

\begin{tabular}{cccc}
\hline Material & $\mathbf{C ~ ( \% )}$ & $\mathbf{H}(\%)$ & $\mathbf{N}(\%)$ \\
\hline 10Sc1NbSZ & 10,31 & 3,33 & 0,29 \\
10Sc1DySZ & 8,58 & 3,02 & 0,39 \\
\hline
\end{tabular}

A presença de álcool nas superfícies dos pós precursores foi confirmada por medidas de espectroscopia na região do infravermelho. A Figura 38 mostra os espectros de FTIR dos pós precursores. Em ambas as amostras, a presença de álcool foi confirmada pelas bandas encontradas a 2970, 2930, 2870, 1560, $1420 \mathrm{~cm}^{-1}$, as quais são referentes às vibrações de grupos alcóxidos. ${ }^{88,89}$ 


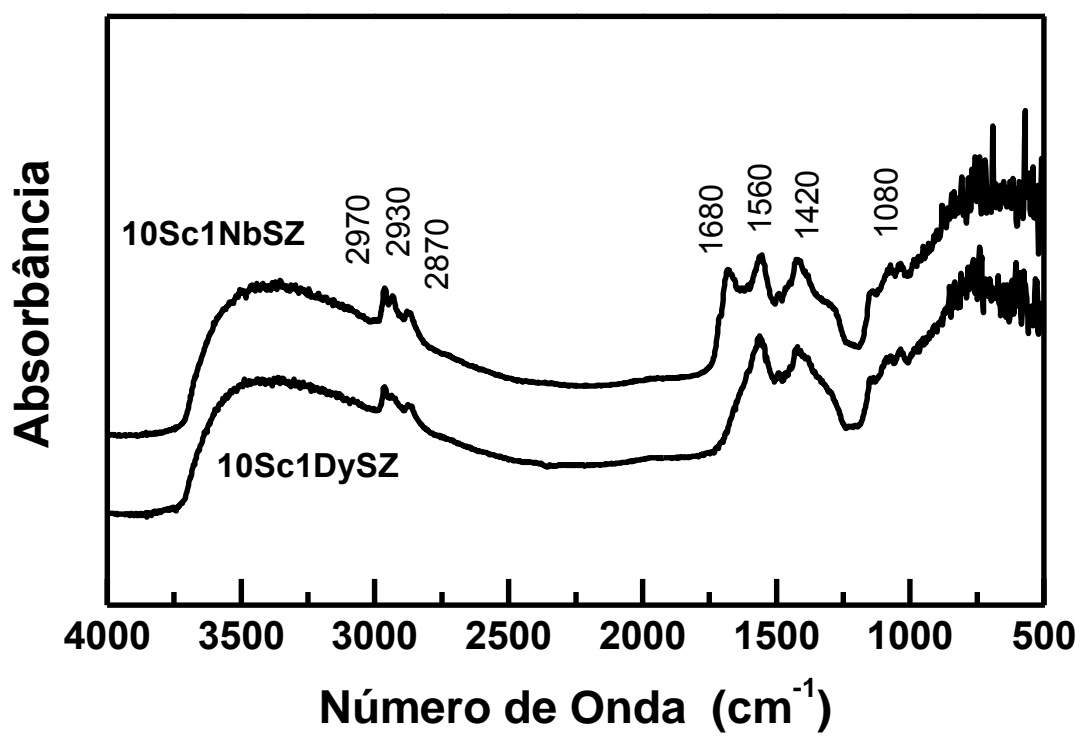

Figura 38. Espectros de infravermelho por refletância difusa dos pós precursores de 10Sc1DySZ e 10Sc1NbSZ sintetizados por coprecipitação de hidróxidos.

A formação da ligação entre átomos de $\mathrm{Zr}$ localizados na superfície das partículas e o oxigênio do grupo alcóxido pode ser verificada pela vibração a $1080 \mathrm{~cm}^{-1} \cdot{ }^{90} \mathrm{~A}$ banda alargada na região de $3500 \mathrm{~cm}^{-1}$ está relacionada ao estiramento das ligações dos grupos $\mathrm{OH}$ fortemente ligados à superfície dos pós. A banda observada a $1680 \mathrm{~cm}^{-1}$, a qual está relacionada ao estiramento $\mathrm{C}=\mathrm{O}$, somente foi detectada em amostras de 10Sc1NbSZ.

A presença de $\mathrm{C}=\mathrm{O}$ no espectro de $10 \mathrm{Sc} 1 \mathrm{NbSZ}$ pode ser explicada com base nos materiais de partida. Enquanto que o 10Sc1DySZ foi sintetizado pela mistura de nitratos, o sal de $\mathrm{Nb}$ utilizado como precursor possui em sua composição cerca de 50\% em massa de oxalato. Este íon teve que ser mantido na solução estoque de $\mathrm{Nb}$ para evitar a precipitação do hidróxido de nióbio. Dessa forma, embora os produtos de solubilidade dos hidróxidos de $\mathrm{Zr}$ e Sc sejam inferiores aos dos seus respectivos oxalatos $\left(K_{p s}=7,9.10^{-43}\right.$ para o $\mathrm{Zr}^{91} \mathrm{e}$ $1,2.10^{-22}$ para $\circ \mathrm{Sc}^{92}$ ) durante a precipitação simultânea dos cátions em $\mathrm{NH}_{4} \mathrm{OH}$ ocorreu a precipitação de uma fração de oxalato, a qual não foi removida durante as etapas de lavagem. Assim, o maior teor de carbono detectado no $10 \mathrm{Sc} 1 \mathrm{NbSZ}$ por análise elementar (Tabela $\mathrm{X}$ ) pode ser atribuído ao oxalato formado durante a síntese. 
Os resultados dos ensaios de calorimetria exploratória diferencial, mostrados na Figura 39, confirmam o comportamento térmico observado nas curvas TG e DTA (Figura 37). Os picos endotérmicos observados até $200{ }^{\circ} \mathrm{C}$ estão relacionados com eliminação parcial de água e álcool. Em relação à curva DTA, houve um pequeno deslocamento dos picos exotérmicos devido às diferentes atmosferas dos experimentos. Esse comportamento é esperado, uma vez que a atmosfera de ar sintético, rica em $\mathrm{O}_{2}$, promove as reações de combustão das moléculas de álcool presentes nas amostras, facilitando a eliminação de compostos orgânicos e fazendo com que esses eventos térmicos ocorram em temperaturas mais baixas em relação aos ensaios realizados sob atmosferas inertes.

$\mathrm{O}$ alargamento do pico em aproximadamente $325^{\circ} \mathrm{C}$ e as variações do sinal nas curvas DSC observadas entre 350 e $500{ }^{\circ} \mathrm{C}$ indicam que a decomposição desses materiais ocorre por meio de mais de uma etapa. Portanto, esses eventos podem estar associados à decomposição dos hidróxidos, bem como, à degradação de moléculas de álcool. Ambas as composições apresentaram pico exotérmico com $\mathrm{T}_{\text {onset }}$ próximo a $510{ }^{\circ} \mathrm{C}$ e $\mathrm{T}_{\text {endset }}$ de aproximadamente $539^{\circ} \mathrm{C}$.

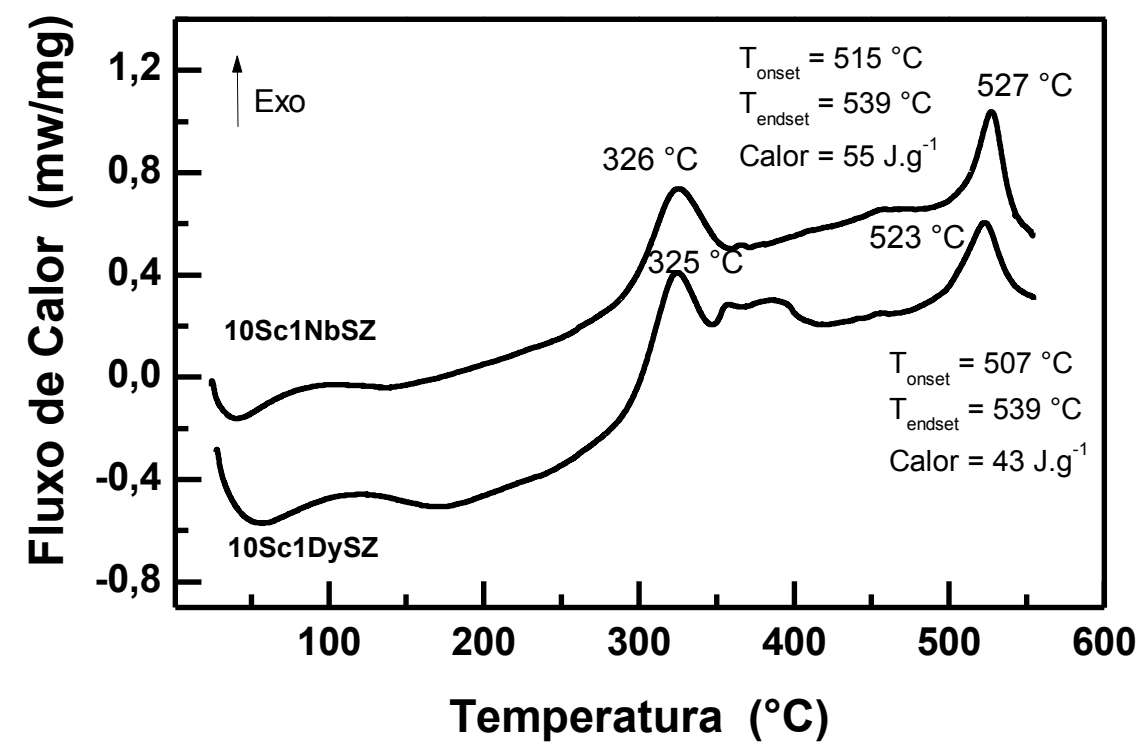

Figura 39. Curvas de DSC, obtidas sob atmosfera dinâmica de $\mathrm{N}_{2}$ com razão de aquecimento de $10{ }^{\circ} \mathrm{C} / \mathrm{min}$, dos precursores 10Sc1DySZ e 10Sc1 NbSZ sintetizados por via úmida. 
Com o objetivo de verificar se o evento térmico observado na faixa de temperatura de 510 a $539{ }^{\circ} \mathrm{C}$ se deve ao processo de cristalização de fase, ensaios de termogravimetria sob atmosfera dinâmica de $\mathrm{N}_{2}$, foram realizados com pós sintetizados de 10Sc1DySZ até 500 e $550{ }^{\circ} \mathrm{C}$ para serem, em seguida, submetidos à difratometria de raios $\mathrm{X}$, e os resultados são mostrados na Figura 40. Somente após tratamento térmico a $550^{\circ} \mathrm{C}$ foi identificada uma única fase cúbica de face centrada (grupo espacial $F m 3 m$ ) por comparação com a ficha PDF 64-9607 da zircônia-escândia. ${ }^{13}$

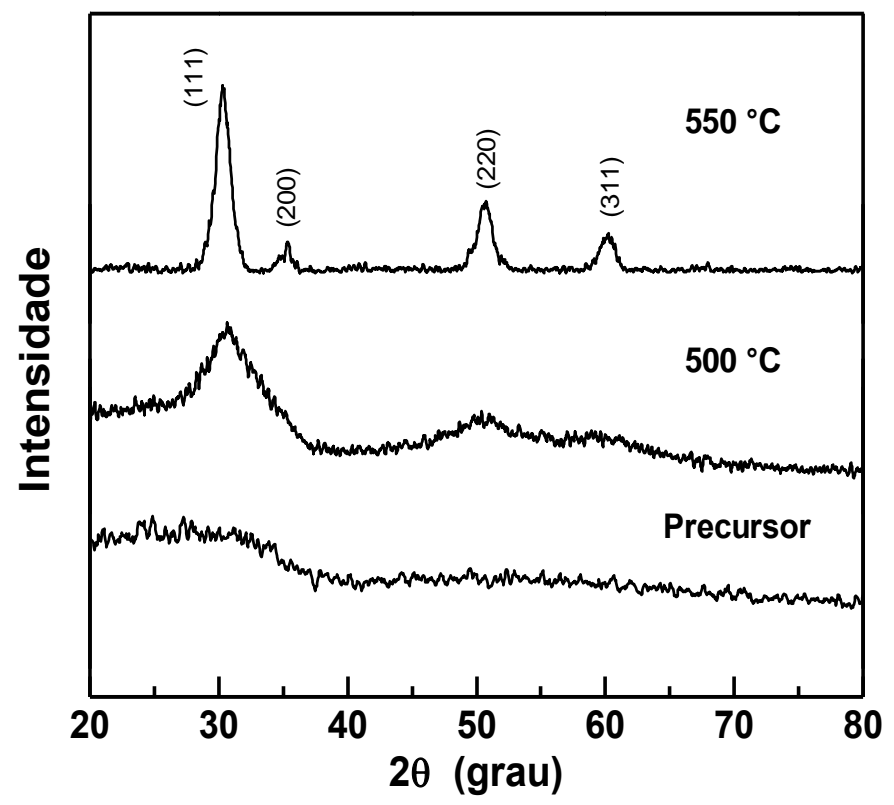

Figura 40. Difratogramas de raios $X$ de 10Sc1DySZ sintetizado antes e após ser submetido à análise termogravimétrica a 500 e $550^{\circ} \mathrm{C}$ e resfriado à temperatura ambiente.

Esses resultados de difração de raios $X$ confirmam que os picos exotérmicos observados nas curvas DTA, na região de $440{ }^{\circ} \mathrm{C}$ (Figura 37) e DSC em aproximadamente $525^{\circ} \mathrm{C}$ (Figura 39) estão relacionados com a cristalização da fase cúbica das soluções sólidas. É interessante ressaltar que embora os ensaios de DTA e DSC tenham sido realizados sob diferentes atmosferas, as temperaturas $T_{\text {endset }}$ apresentaram-se bem semelhantes. Portanto, esses resultados indicam que a presença de oxalato no precursor de 10Sc1 NbSZ não influenciou na cristalização da fase cúbica. 
Dessa forma, com base nos resultados de análise térmica e difratometria de raios $X$, todas as composições estudadas preparadas por coprecipitação de hidróxidos foram calcinadas a $500{ }^{\circ} \mathrm{C}$ por $2 \mathrm{~h}$. As composições dos materiais sintetizados foram confirmadas por fluorescência de raios $X$ em amostras calcinadas. As diferenças entre os valores previstos e obtidos estão dentro do erro experimental.

Os difratogramas de raios $X$ dos pós calcinados contendo diferentes teores de $\mathrm{Dy}_{2} \mathrm{O}_{3}$ são apresentados na Figura 41. Para comparação, o difratograma do pó de 10ScSZ (como recebido) também é apresentado. As posições angulares das reflexões das fases cúbica $(c)$ e romboédrica $(\beta)$, fichas PDF 64-9607 e 64-9610, respectivamente, são indicadas na parte inferior da Figura 41. Todas as composições sintetizadas por coprecipitação apresentaram picos de difração alargados. Aparentemente houve a estabilização da fase cúbica à temperatura ambiente nos pós calcinados. Resultados semelhantes foram encontrados para os materiais calcinados contendo diferentes teores molares de $\mathrm{Nb}_{2} \mathrm{O}_{5}$ estudados $(0,25 ; 0,5$ e $1 \%)$. O difratograma de raios $X$ do $10 \mathrm{ScSZ}$ é característico da fase romboédrica da zircônia-escândia (grupo espacial $R 3$ ).

O tamanho médio de cristalito dos pós calcinados e do material comercial determinados pelo método de Debye-Scherrer ${ }^{69}$ são da ordem de 6 e $24 \mathrm{~nm}$, respectivamente. Esses valores estão de acordo com o diagrama de fases em nanoescala (Figura 36), no qual foi termodinamicamente demonstrado que tamanho de cristalito da ordem de $25 \mathrm{~nm}$ favorece a formação da estrutura romboédrica $\beta$ no 10 ScSZ. 


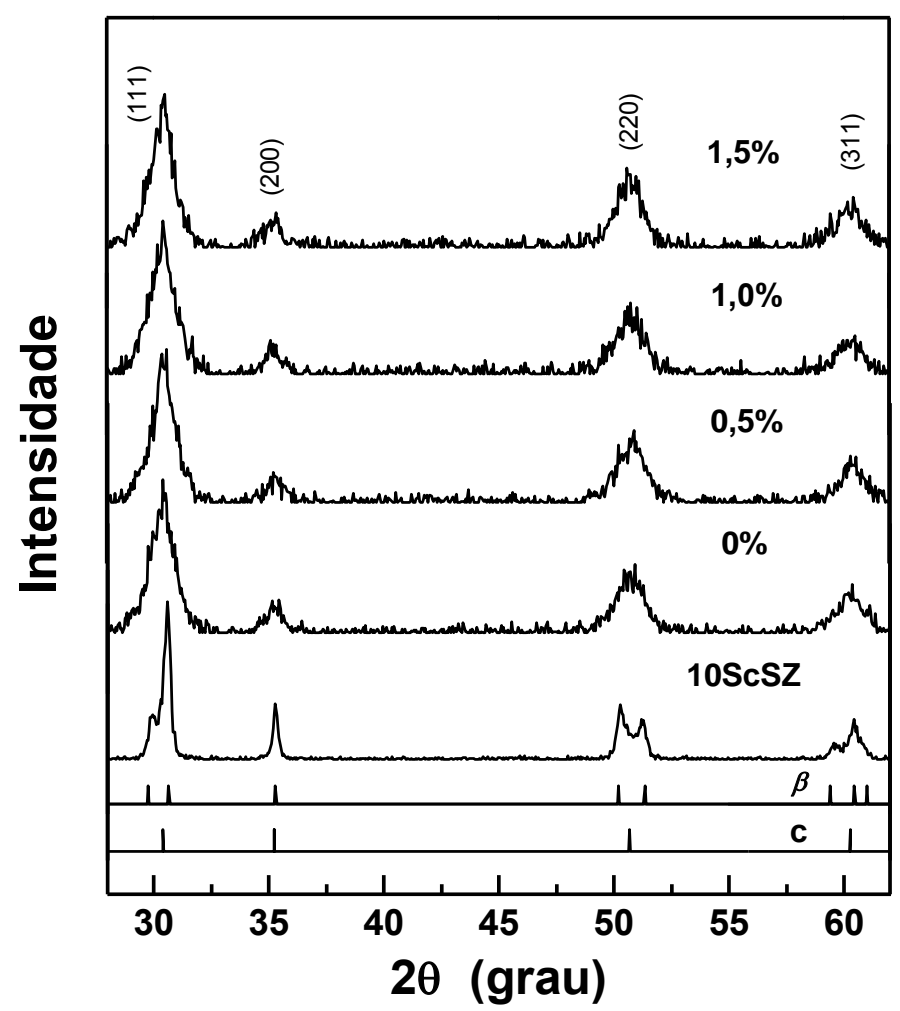

Figura 41. Difratogramas de raios $X$ dos pós de zircônia-escândia comercial, como recebido, e sintetizados por coprecipitação contendo diferentes teores de óxido de disprósio após calcinação a $500{ }^{\circ} \mathrm{C}$ por $2 \mathrm{~h}$.

De modo geral, a técnica de espectroscopia na região do infravermelho com transformada de Fourier na região de número de onda abaixo de $800 \mathrm{~cm}^{-1}$ pode ser utilizada para determinação de estruturas cristalinas da $\mathrm{ZrO}_{2}$ devido às diferentes vibrações estruturais. ${ }^{89,93}$

$\mathrm{O}$ espectro FTIR do material calcinado contendo $1 \% \mathrm{~mol}$ de $\mathrm{Dy}_{2} \mathrm{O}_{3}$ foi registrado na faixa de 300 a $800 \mathrm{~cm}^{-1}$. Para comparação, também foram registrados os espectros dos pós de 10ScSZ (Figura 42). De acordo com Phillippi, ${ }^{93}$ a fase cúbica metaestável do $\mathrm{ZrO}_{2}$ apresenta apenas uma banda localizada a $480 \mathrm{~cm}^{-1}$, enquanto que no espectro da zircônia estabilizada com ítria, um ombro adicional por volta de $610 \mathrm{~cm}^{-1}$ normalmente é observado. Dessa forma, por comparação com os espectros reportados na literatura, as bandas localizadas em torno de 470 e $610 \mathrm{~cm}^{-1}$ para o 10Sc1DySZ podem ser atribuídas à estrutura cúbica tipo fluorita. 


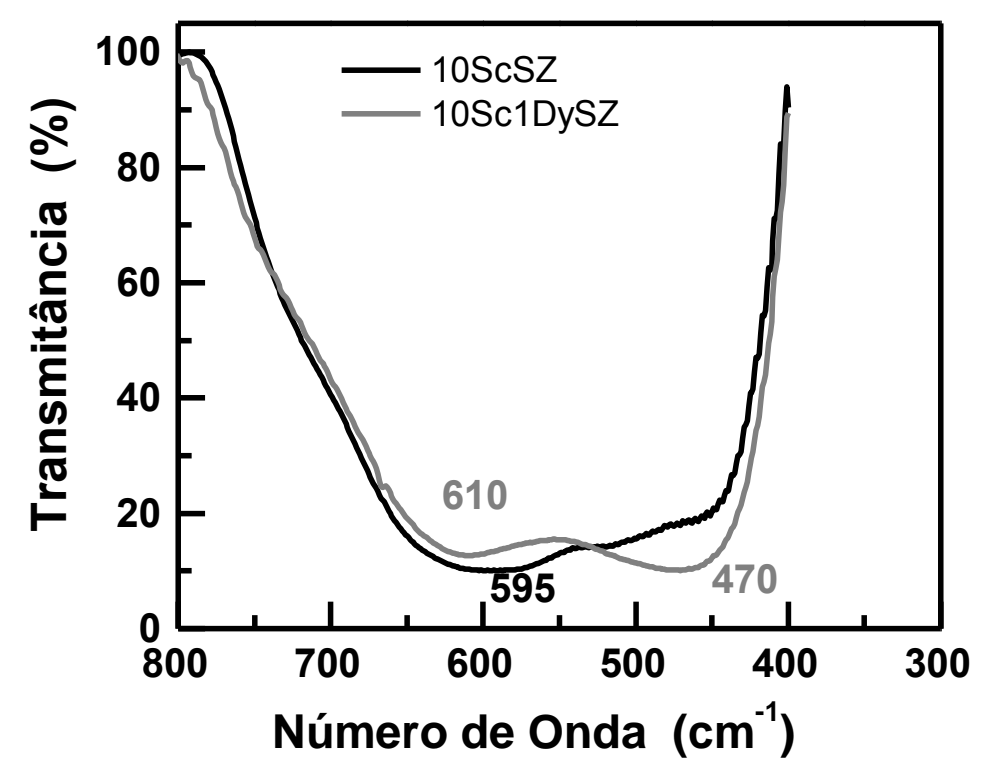

Figura 42. Espectro de FTIR do pó calcinado de 10Sc1DySZ sintetizado por coprecipitação e de $10 \mathrm{ScSZ}$ comercial.

Por outro lado, o espectro da zircônia-escândia comercial possui uma única banda em aproximadamente $595 \mathrm{~cm}^{-1}$, a qual não está relacionada com a estrutura monoclínica (principal banda de transmissão a $740 \mathrm{~cm}^{-1}$ ) e nem tetragonal (bandas características localizadas a 435 e $510 \mathrm{~cm}^{-1}$ ). Portanto, o espectro do 10ScSZ é atribuído à estrutura romboédrica, de acordo com o difratograma de raios $X$ (Figura 41). Não foi encontrado na literatura nenhum resultado de espectroscopia na região do infravermelho da fase romboédrica da zircônia-escândia.

As imagens obtidas em microscópio eletrônico de transmissão dos pós de 10Sc1DySZ e 10Sc1NbSZ calcinados são mostradas na Figura 43. Para ambos os materiais, é possível perceber que as partículas encontram-se aglomeradas após tratamento térmico, comportamento similar foi encontrado para o material sem aditivo (Figura 32). O tamanho das partículas é de 5-8 nm, o que está de acordo com o tamanho médio de cristalito encontrado por difração de raios $\mathrm{X}$. 

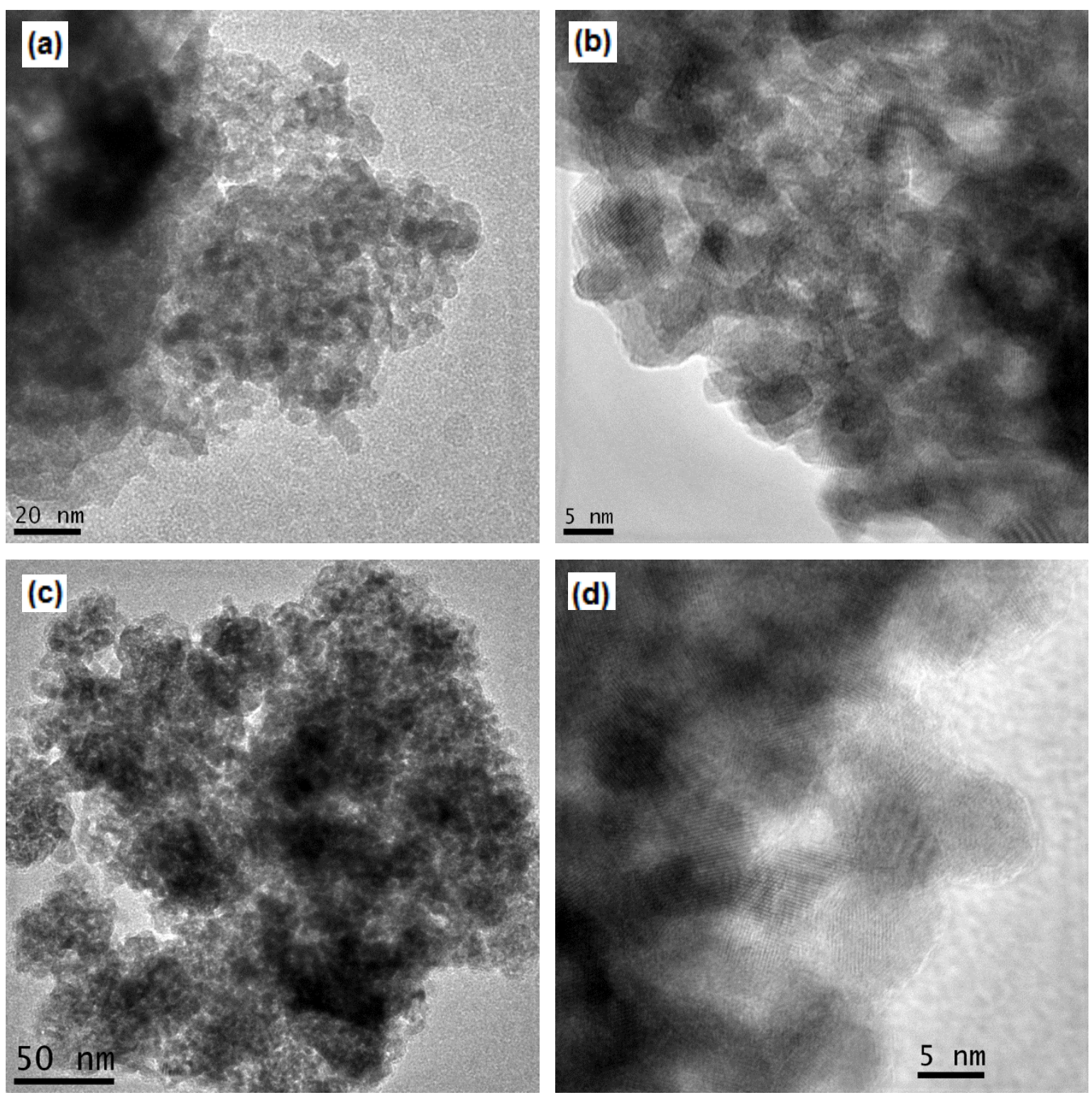

Figura 43. Micrografias obtidas por microscópio eletrônico de transmissão dos pós calcinados de (a e b) 10Sc1DySZ e (c e d) 10Sc1NbSZ.

Estes resultados evidenciam que apesar das lavagens com álcool inibirem a formação de aglomerados, pela minimização do teor de moléculas de água no precipitado, ainda assim ocorreu a formação de aglomerados fortes nos pós calcinados, que pode prejudicar o processo de densificação. 


\section{Caracterização dos Compactos}

Os resultados obtidos por dilatometria para compactos a verde de $10 \mathrm{ScSZ}$ contendo $1 \% \mathrm{~mol}$ dos aditivos são mostrados na Figura 44. Ambos os materiais apresentaram início de retração próximo de $730{ }^{\circ} \mathrm{C}$. O compacto contendo Dy (Figura 44a) retraiu cerca de $20 \%$ até a temperatura de $1450{ }^{\circ} \mathrm{C}$ e para o 10Sc1NbSZ (Figura 44b), a retração foi de aproximadamente 22\% na mesma faixa de temperatura.

Três inflexões bem definidas foram observadas na curva de derivada da retração linear para 0 material contendo Dy e duas inflexões foram encontradas para a amostra contendo $\mathrm{Nb}$. Essa diferença pode ser atribuída à aglomeração dos materiais calcinados ou, até mesmo, estar relacionada com maior habilidade do nióbio de promover a densificação. De modo geral, essas inflexões ocorrem devido à presença de diferentes aglomerados. A partir da curva de densidade relativa $\left(\rho_{R}\right)$ em função da temperatura (Figura 45), calculada com base nos resultados de dilatometria, tem-se que ambos os materiais apresentam valores de densidade inferiores a $80 \%$ até $1450{ }^{\circ} \mathrm{C}$. Dessa forma, a relativamente baixa densificação, pode ser atribuída à aglomeração das partículas nanométricas, evidenciada pelas micrografias (Figura 43). 

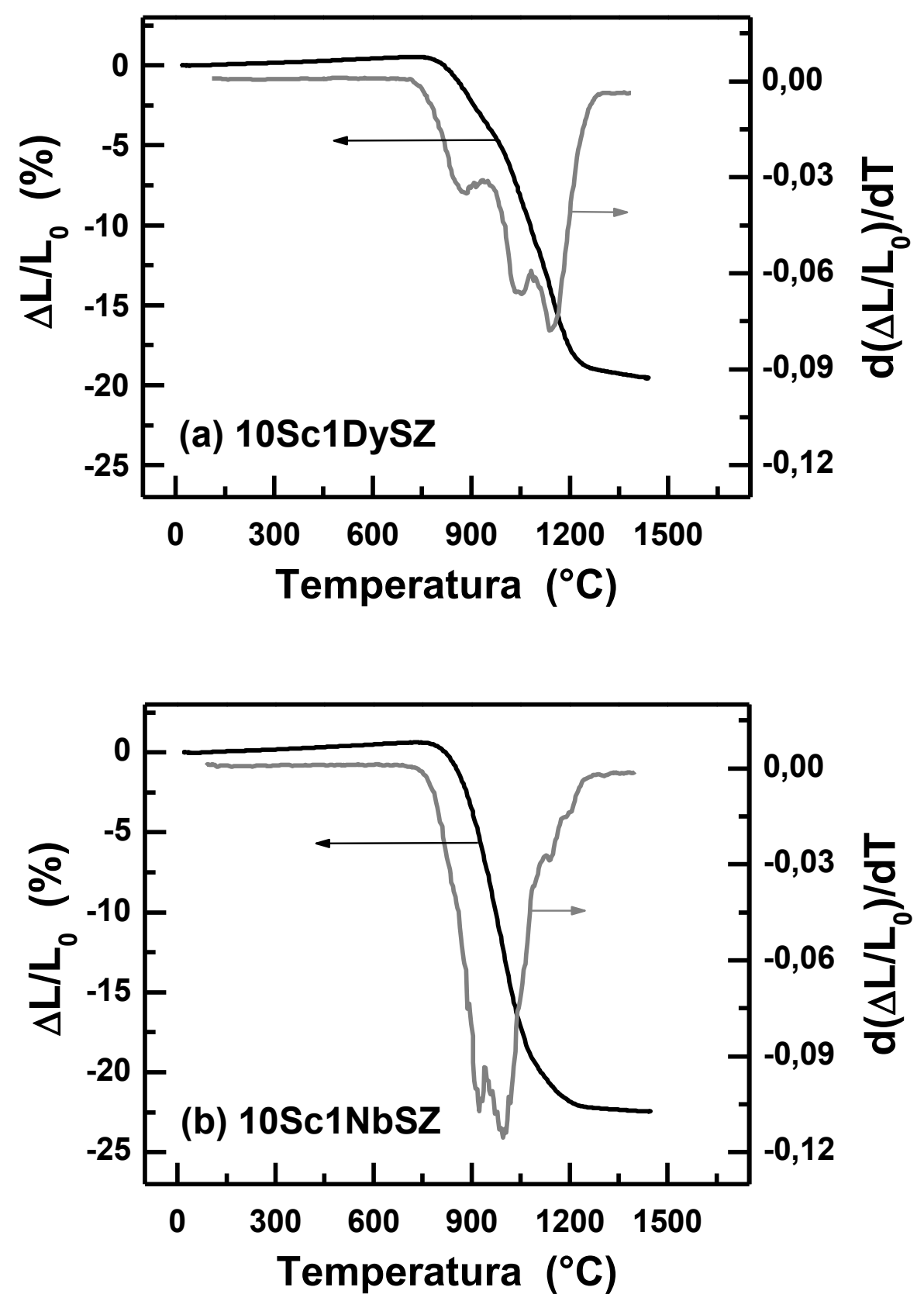

Figura 44. Retração linear e derivada da retração linear dos compactos de (a) 10Sc1DySZ e (b) 10Sc1NbSZ. 


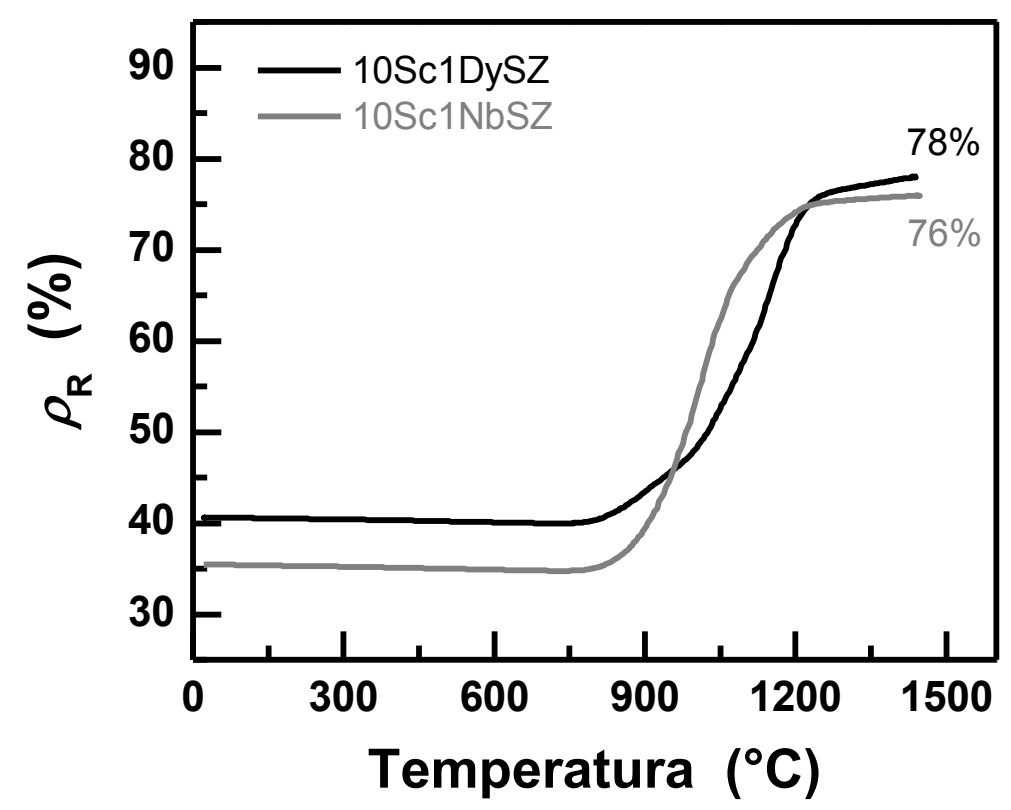

Figura 45. Curvas de densidade relativa em função da temperatura para 0 (a) 10Sc1 NbSZ e (b) 10Sc1DySZ obtidas a partir de dilatometria.

Para verificar a sinterabilidade das amostras sintetizadas por coprecipitação, diversas condições de sinterização foram avaliadas. A Tabela XI sumariza as densidades relativas encontradas para cada condição estudada. A densidade obtida foi da ordem de $85 \%$ mesmo após sinterização a $1550{ }^{\circ} \mathrm{C}$ por 10 h. O aumento de 1500 para $1550{ }^{\circ} \mathrm{C}$, não influenciou a densidade. Amostras sinterizadas sem prévio tratamento térmico de calcinação apresentaram densidades relativas semelhantes às das amostras calcinadas a $500{ }^{\circ} \mathrm{C}$ por $2 \mathrm{~h}$. Todas as composições estudadas apresentaram valores de densidade muito próximos. Esses resultados confirmam que a principal etapa do processamento onde ocorre a aglomeração é durante a precipitação dos hidróxidos.

De acordo com a literatura, cerâmicas à base de 10ScSZ, preparadas por coprecipitação de hidróxidos são sinterizadas pelo método convencional em elevadas temperaturas (acima de $1500{ }^{\circ} \mathrm{C}$ ).${ }^{94} \mathrm{~A}$ introdução de aditivos pode promover a diminuição da temperatura de sinterização. ${ }^{44}$ Além disso, a utilização de outras técnicas de sinterização pode promover a densificação desses materiais. $^{36,95,96}$ 
Tabela XI. Valores de densidade relativa $\left(\rho_{R}\right)$ encontrados para amostras de 10Sc1DySZ e 10Sc1NbSZ preparadas por coprecipitação, calcinadas a $500{ }^{\circ} \mathrm{C}$ por $2 \mathrm{~h}$ e sinterizadas em diferentes temperaturas $(\mathrm{T})$ e tempos de patamar $(\mathrm{t})$.

\begin{tabular}{cccc}
\hline $\mathbf{T}\left({ }^{\circ} \mathbf{C}\right)$ & $\mathbf{t}(\mathbf{h})$ & $\boldsymbol{\rho}_{\boldsymbol{R} \text { 10Sc1Dysz }}(\%)$ & $\boldsymbol{\rho}_{\boldsymbol{R} \text { 10sc1Nbsz }}(\%)$ \\
\hline 1500 & 10 & $84,8 \pm 0,4$ & $85,8 \pm 0,4$ \\
1550 & 2 & $81,1 \pm 0,2$ & $83,6 \pm 0,2$ \\
1550 & 10 & $85,1 \pm 0,9$ & $86,4 \pm 1,2$ \\
${ }^{*} 1550$ & 10 & $84,0 \pm 0,6$ & $87,4 \pm 0,8$ \\
\hline
\end{tabular}

${ }^{*}$ Amostras sinterizadas sem prévio tratamento térmico de calcinação.

Outro aspecto importante após a sinterização é a composição de fases cristalina. Os difratogramas de raios $X$ das amostras sinterizadas a 1500 e $1550{ }^{\circ} \mathrm{C}$ por $10 \mathrm{~h}$ de $10 \mathrm{Sc} 1 \mathrm{DySZ}$ e 10Sc1NbSZ são apresentados na Figura 46, como exemplo. Apenas a fase cúbica foi identificada nos difratogramas dos materiais sinterizados. Portanto, a introdução de $1 \%$ mol dos aditivos sintetizados pelo método de coprecipitação promoveu a estabilização total da fase cúbica da zircônia-escândia à temperatura ambiente, após tratamento térmico a alta temperatura. 

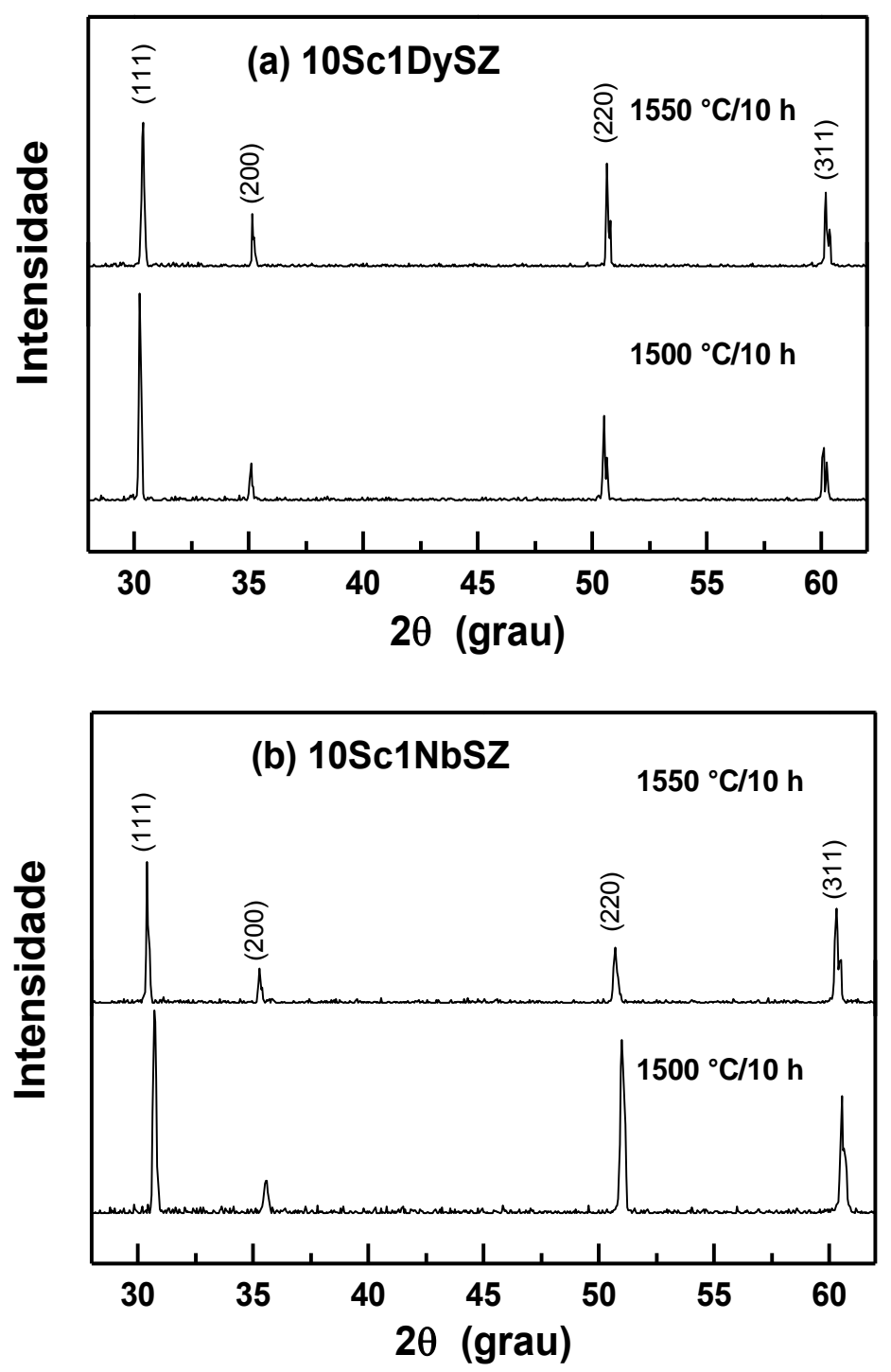

Figura 46. Difratogramas de raios $X$ de amostras de (a) 10Sc1DySZ e (b) $10 \mathrm{Sc} 1 \mathrm{NbSZ}$ sinterizadas a 1500 e $1550{ }^{\circ} \mathrm{C}$ por $10 \mathrm{~h}$.

Além disso, a estabilização da fase cúbica também foi observada em amostras contendo diferentes teores dos aditivos. Os difratogramas de raios $\mathrm{X}$ das amostras sinterizadas a $1450{ }^{\circ} \mathrm{C}$ por tempo de patamar nulo são apresentados nas Figuras 47 e 48 para amostras contendo Dy e $\mathrm{Nb}$, respectivamente. Os índices de Miller correspondem à estrutura cúbica. A faixa angular de 49 a $53^{\circ}$ está em destaque nas Figuras 47b e 48b. 
Os picos demarcados por $\beta$ são referentes à fase romboédrica. É interessante notar que houve a estabilização parcial da fase cúbica à temperatura ambiente na amostra sintetizada por coprecipitação sem aditivo, o que está de acordo com o estudo da estabilidade de fases das nanopartículas de zircônia-escândia. A completa estabilização da fase cúbica ocorreu a partir de $1 \%$ de $\mathrm{Dy}_{2} \mathrm{O}_{3}$ e $0,5 \%$ de $\mathrm{Nb}_{2} \mathrm{O}_{5}$. Teores molares inferiores promoveram a estabilização parcial da fase cúbica.
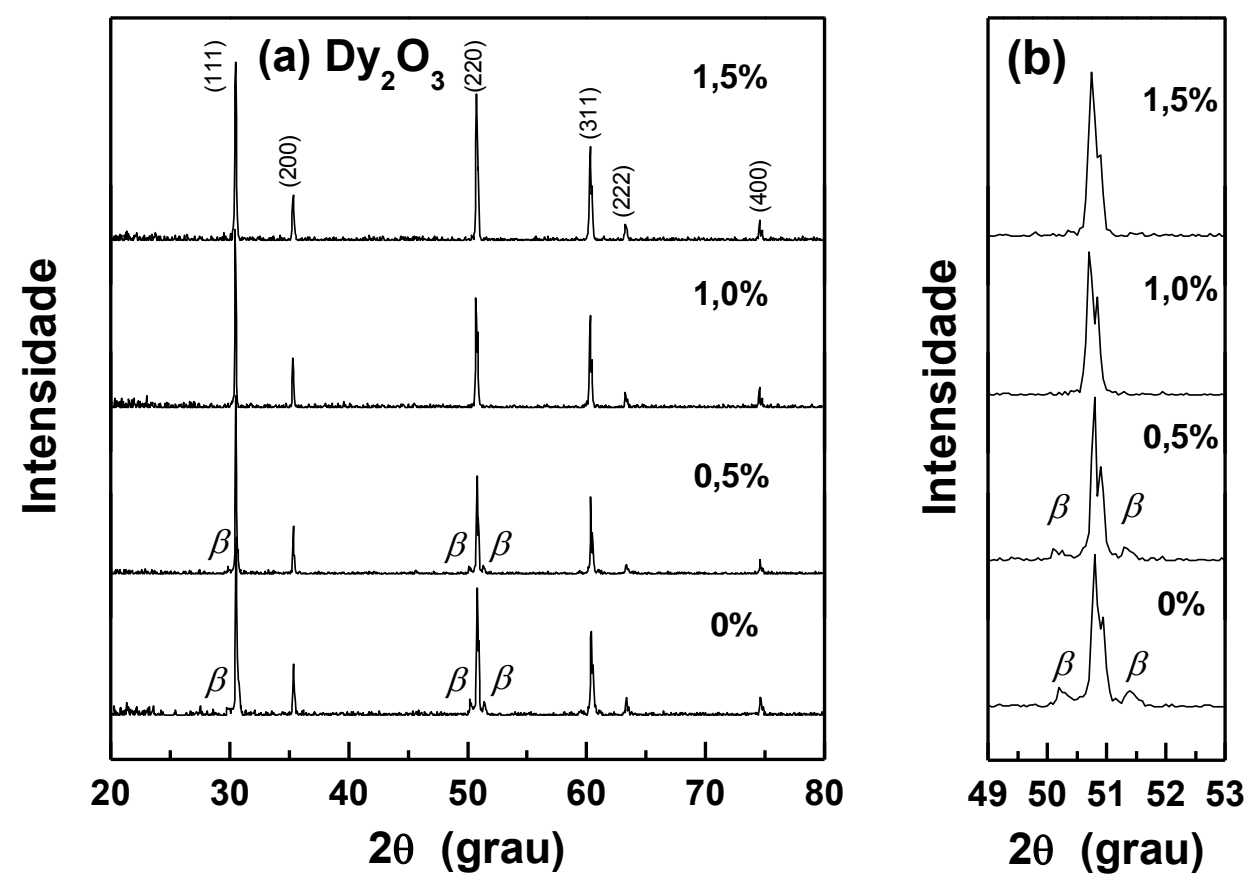

Figura 47. Difratogramas de raios $X$ de amostras de $10 \mathrm{ScSZ}$ contendo diferentes teores molares de $\mathrm{Dy}_{2} \mathrm{O}_{3}$ sinterizadas a $1450{ }^{\circ} \mathrm{C}$ por tempo de patamar nulo na faixa de $2 \theta$ entre (a) 20 e $80^{\circ}$ e (b) 49 e $53^{\circ}$.

$\mathrm{O}$ menor teor de $\mathrm{Nb}_{2} \mathrm{O}_{5}$ necessário para a estabilização completa da fase cúbica pode ser atribuído ao raio iônico do $\mathrm{Nb}^{5+}$, o qual é inferior ao raio do $\mathrm{Zr}^{4+}$, e que pode facilitar a formação da solução sólida. Estes resultados confirmam que a introdução de Dy e $\mathrm{Nb}$ na zircônia-escândia por meio do método de coprecipitação possibilita a obtenção de um pó com fase única cúbica à temperatura ambiente. 

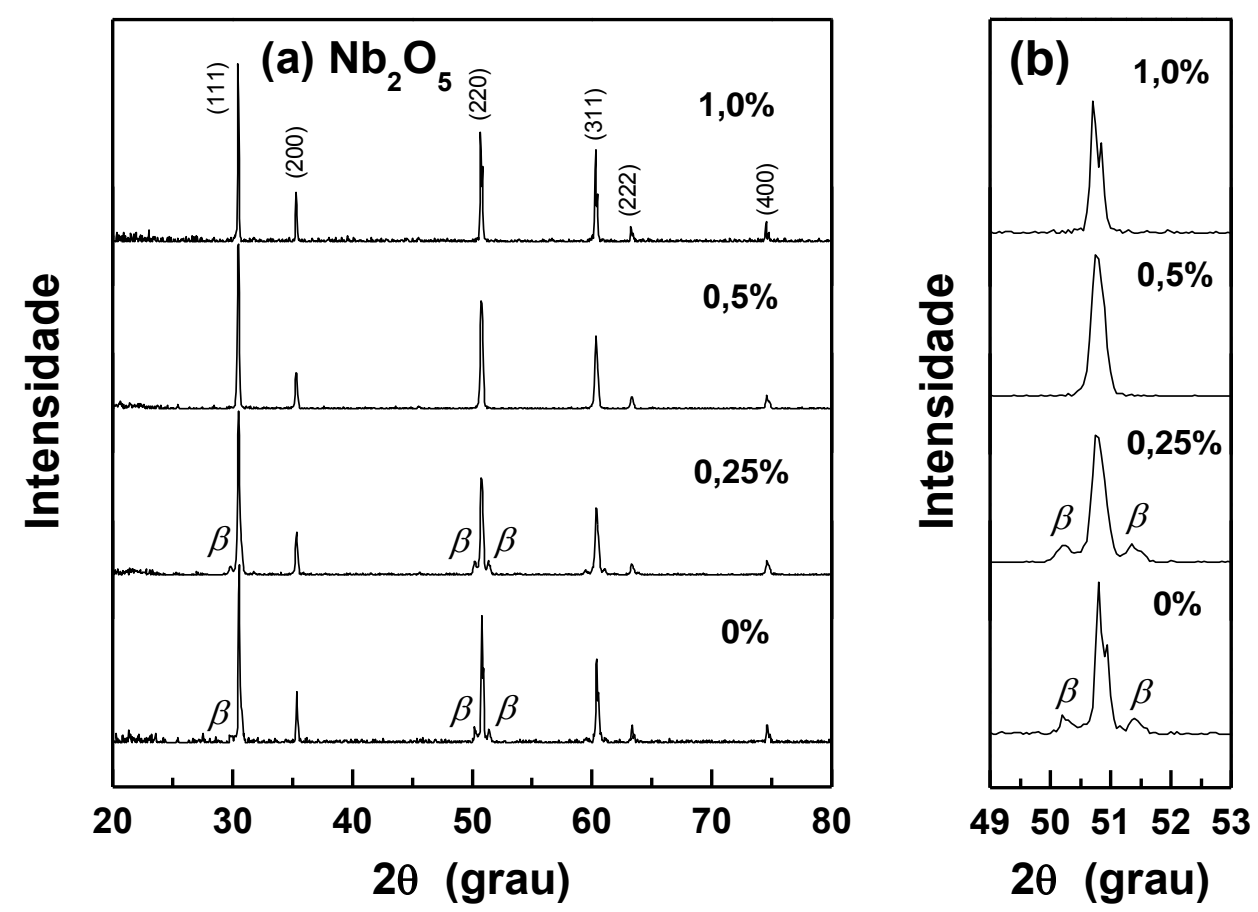

Figura 48. Difratogramas de raios $X$ de amostras de $10 \mathrm{ScSZ}$ contendo diferentes teores molares de $\mathrm{Nb}_{2} \mathrm{O}_{5}$ sinterizadas a $1450{ }^{\circ} \mathrm{C}$ por tempo de patamar nulo na faixa de $2 \theta$ entre (a) 20 e $80^{\circ}$ e (b) 49 e $53^{\circ}$.

A estabilidade térmica da fase cúbica foi verificada por difratometria de raios $\mathrm{X}$ em alta temperatura e por ensaios de DTA. Os difratogramas de raios $\mathrm{X}$, obtidos durante aquecimento e resfriamento, na faixa de $2 \theta$ de 46 a $56^{\circ}$, são mostrados nas Figuras 49-51. A seta indica a sequência em que foram realizadas as medidas. As temperaturas em ${ }^{\circ} \mathrm{C}$ estão indicadas para cada difratograma.

A transição de fase reversível cúbica-romboédrica, entre 500 e $600{ }^{\circ} \mathrm{C}$, foi evidenciada para o 10ScSZ comercial (Figura 49a) devido ao desaparecimento dos picos de difração (104) e (110) referentes à fase romboédrica e surgimento do pico (220), característico da fase cúbica. A transição de fase também foi observada para o 10ScSZ sintetizado sem aditivo (Figura 49b), o qual apresentou baixo teor de fase $\beta$. Por outro lado, nenhuma alteração no pico de difração (220) ocorreu para os materiais com estrutura cúbica estabilizada à temperatura ambiente, como pode ser observado nas Figuras 50 e 51 . Os materiais com estrutura cristalina parcialmente estabilizada apresentaram comportamento semelhante ao $10 \mathrm{ScSZ}$ sem aditivo sintetizado. 

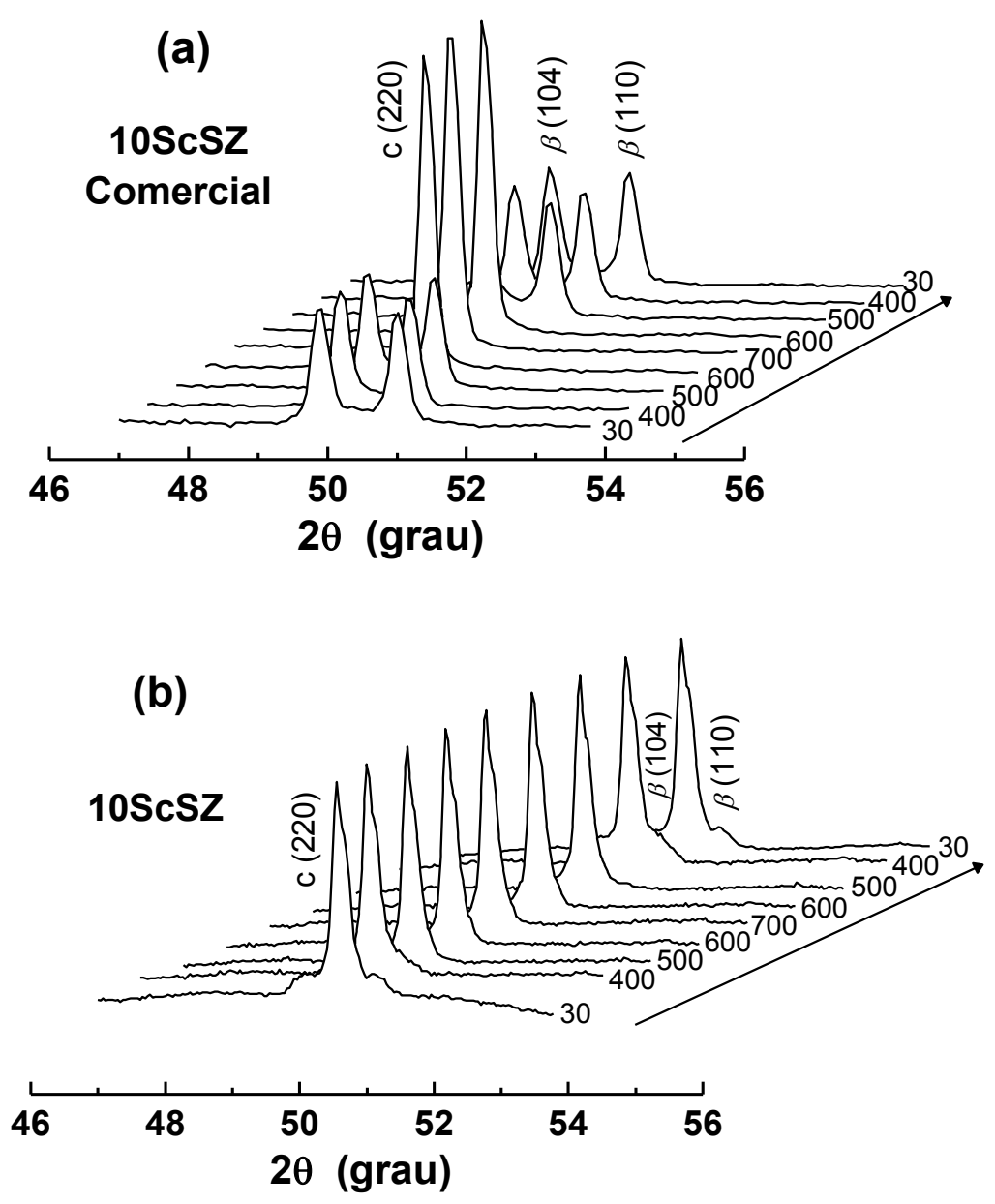

Figura 49. Difratogramas de raios $X$ em alta temperatura obtidos durante aquecimento e resfriamento, de amostras sinterizadas a $1450{ }^{\circ} \mathrm{C}$ por 0 h. (a) $10 \mathrm{ScSZ}$ comercial e (b) $10 \mathrm{ScSZ}$ sintetizado por coprecipitação. 

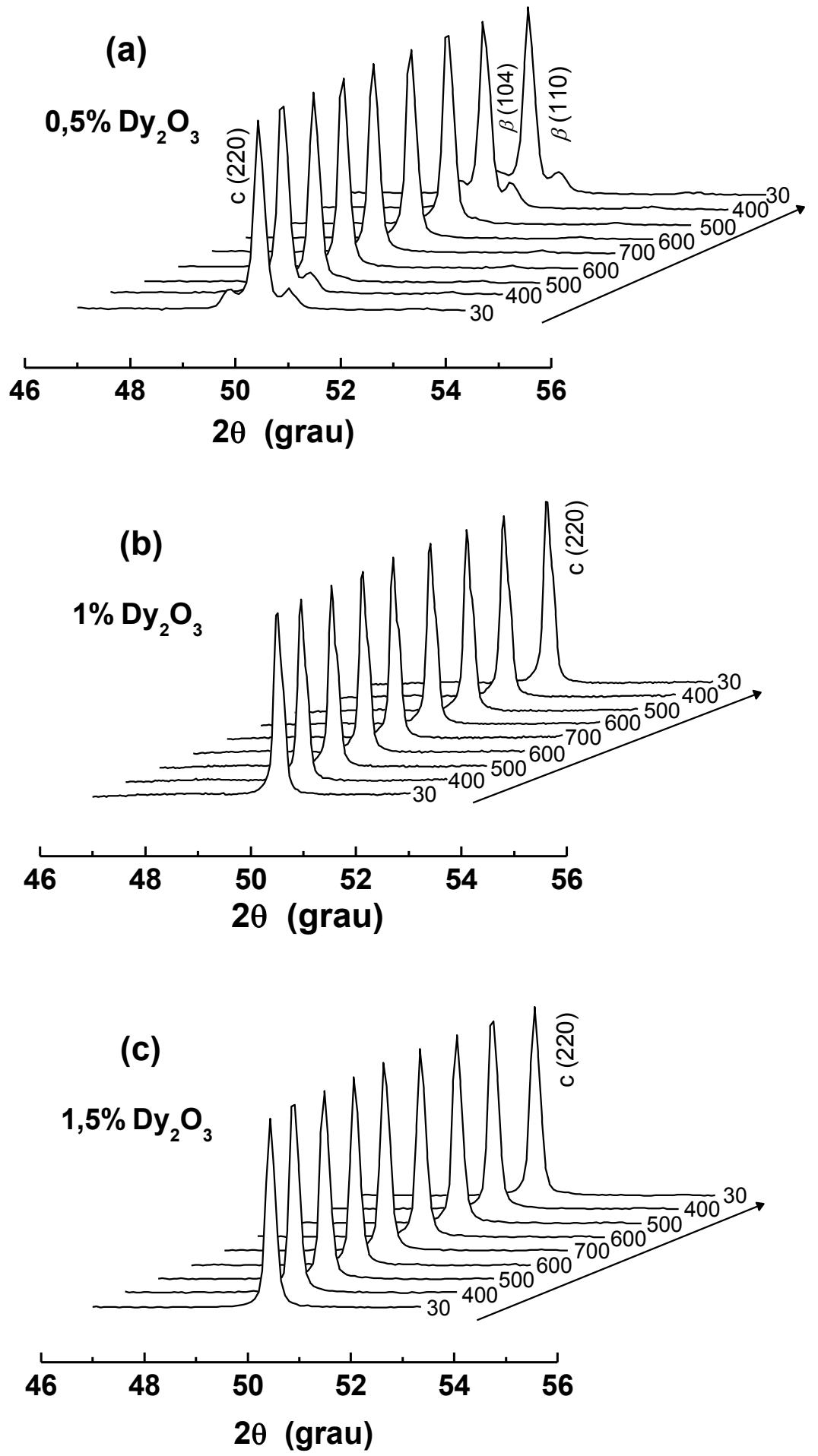

Figura 50. Difratogramas de raios $X$ em alta temperatura obtidos durante aquecimento e resfriamento, de amostras sinterizadas a $1450{ }^{\circ} \mathrm{C}$ por 0 h. $10 \mathrm{ScSZ}$ contendo teores molares de $\mathrm{Dy}_{2} \mathrm{O}_{3}$ : (a) $0,5 \%$; (b) $1 \%$ e (c) $1,5 \%$. 

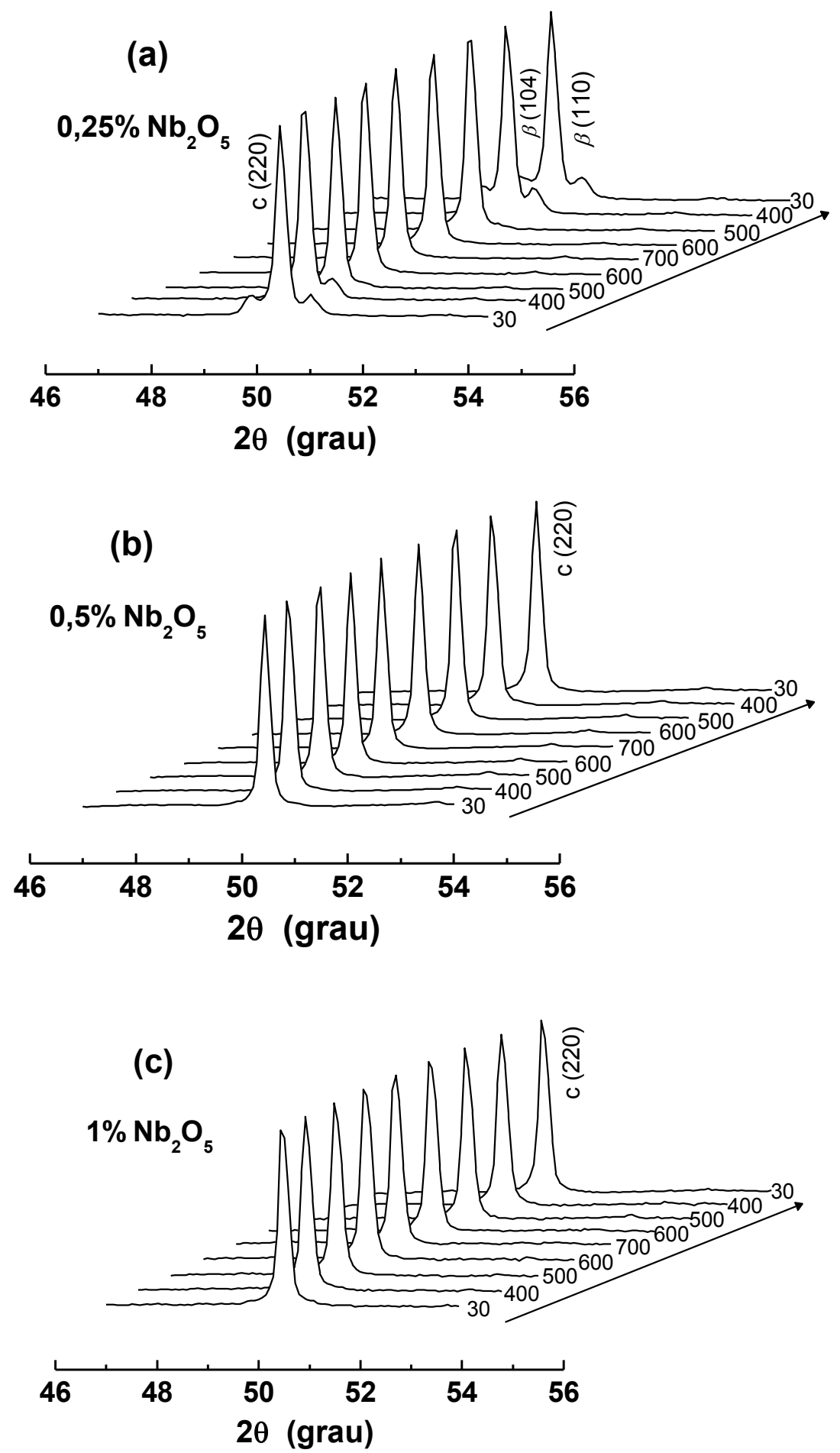

Figura 51. Difratogramas de raios $X$ em alta temperatura obtidos durante aquecimento e resfriamento, de amostras sinterizadas a $1450{ }^{\circ} \mathrm{C}$ por 0 h. $10 \mathrm{ScSZ}$ contendo teores molares de $\mathrm{Nb}_{2} \mathrm{O}_{5}$ : (a) $0,25 \%$; (b) $0,5 \%$ e (c) $1 \%$. 
Ensaios de DTA, de amostras de 10Sc1DySZ e 10ScSZ (como recebido) sinterizadas a $1450{ }^{\circ} \mathrm{C}$ sem patamar, foram realizados em ciclos térmicos de aquecimento e resfriamento a partir da temperatura ambiente até $700{ }^{\circ} \mathrm{C}$ sob atmosfera dinâmica de ar. As curvas DTA são apresentadas na Figura 52. Durante o aquecimento, o $10 \mathrm{ScSZ}$ apresentou um evento endotérmico (Figura 52a) com $\mathrm{T}_{\text {onset }}$ de $557{ }^{\circ} \mathrm{C}$. Um evento exotérmico, com $\mathrm{T}_{\text {onset }}$ de $531^{\circ} \mathrm{C}$ foi observado durante o resfriamento. Esse comportamento é atribuído à transição de fase reversível cúbica-romboédrica. ${ }^{23,85} \mathrm{~A}$ entalpia molar de transição de fase $\left(\Delta H_{\beta \rightarrow c}\right)$ encontrada para o $10 \mathrm{ScSZ}$ comercial foi de $1,28 \mathrm{~kJ} / \mathrm{mol}$, este valor é similar ao reportado para a zircônia contendo $11 \% \mathrm{~mol}$ de escândia $\left(\Delta H_{\beta \rightarrow c}=1,11 \mathrm{~kJ} / \mathrm{mol}\right) .{ }^{85}$ Por outro lado, nenhum evento térmico foi detectado para a amostra de 10Sc1DySZ (Figura 52b) evidenciando, mais uma vez, a total estabilização da fase cúbica à temperatura ambiente pelo aditivo.

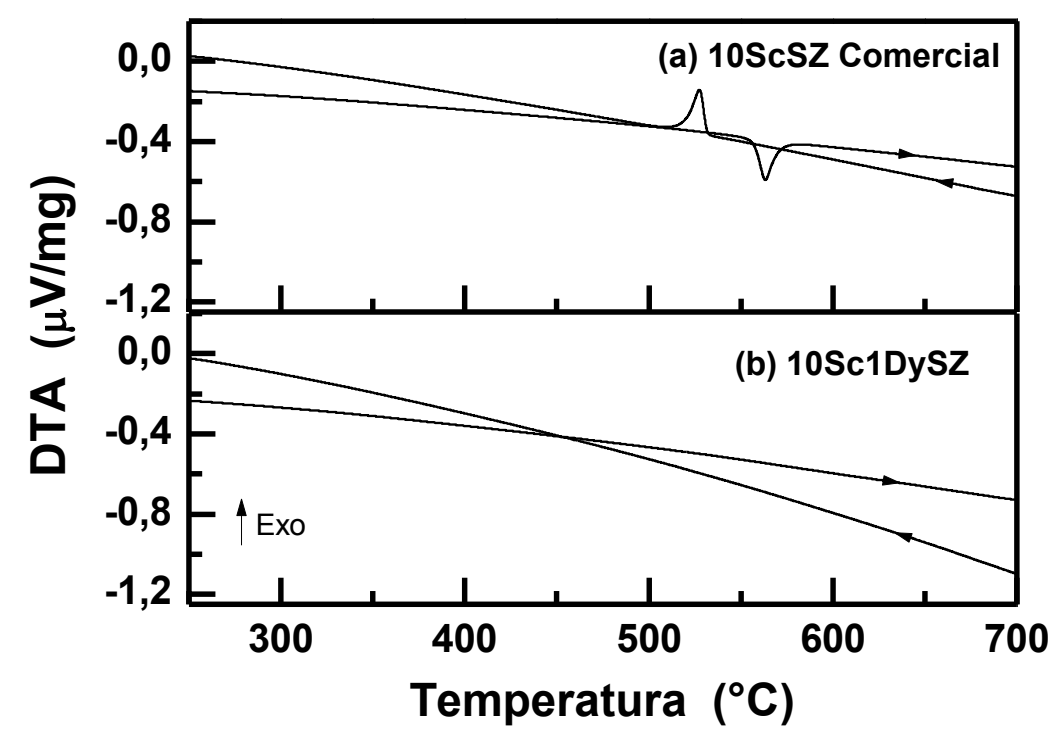

Figura 52. Curvas DTA obtidas em função de ciclos térmicos com razão de aquecimento e resfriamento de $10{ }^{\circ} \mathrm{C} / \mathrm{min}$, sob atmosfera dinâmica de ar sintético, de amostras de (a) 10ScSZ comercial e (b) $10 \mathrm{Sc} 1 \mathrm{DySZ}$ sinterizadas a $1450^{\circ} \mathrm{C}$ por $0 \mathrm{~h}$. 
Dessa forma, os resultados de difratometria de raios $\mathrm{X}$ em alta temperatura e análise térmica diferencial revelaram que houve a supressão da transformação de fase cúbica-romboédrica em amostras com estrutura cristalina cúbica totalmente estabilizada à temperatura ambiente, para teores específicos dos aditivos.

Para análise da microestrutura da zircônia-escândia contendo aditivos foi realizada a fratura de amostras sinterizadas a $1450^{\circ} \mathrm{C}$. A Figura 53 mostra, como exemplo, as micrografias de regiões densas da superfície de fratura, obtidas por microscópio eletrônico de varredura, de amostras contendo $1 \%$ de $\mathrm{Dy}_{2} \mathrm{O}_{3}$ (Figura 53a) e $\mathrm{Nb}_{2} \mathrm{O}_{5}$ (Figura 53b). Podem ser observadas microrregiões contendo elevada concentração de grãos nanométricos inseridas em grãos micrométricos. Essa característica pode ser atribuída à presença de aglomerados, de acordo com os resultados de dilatometria (Figura 44). Dessa forma, o elevado grau de aglomeração das nanopartículas promoveu a formação de uma microestrutura heterogênea nos compactos sinterizados e prejudicou o processo de densificação desses materiais.
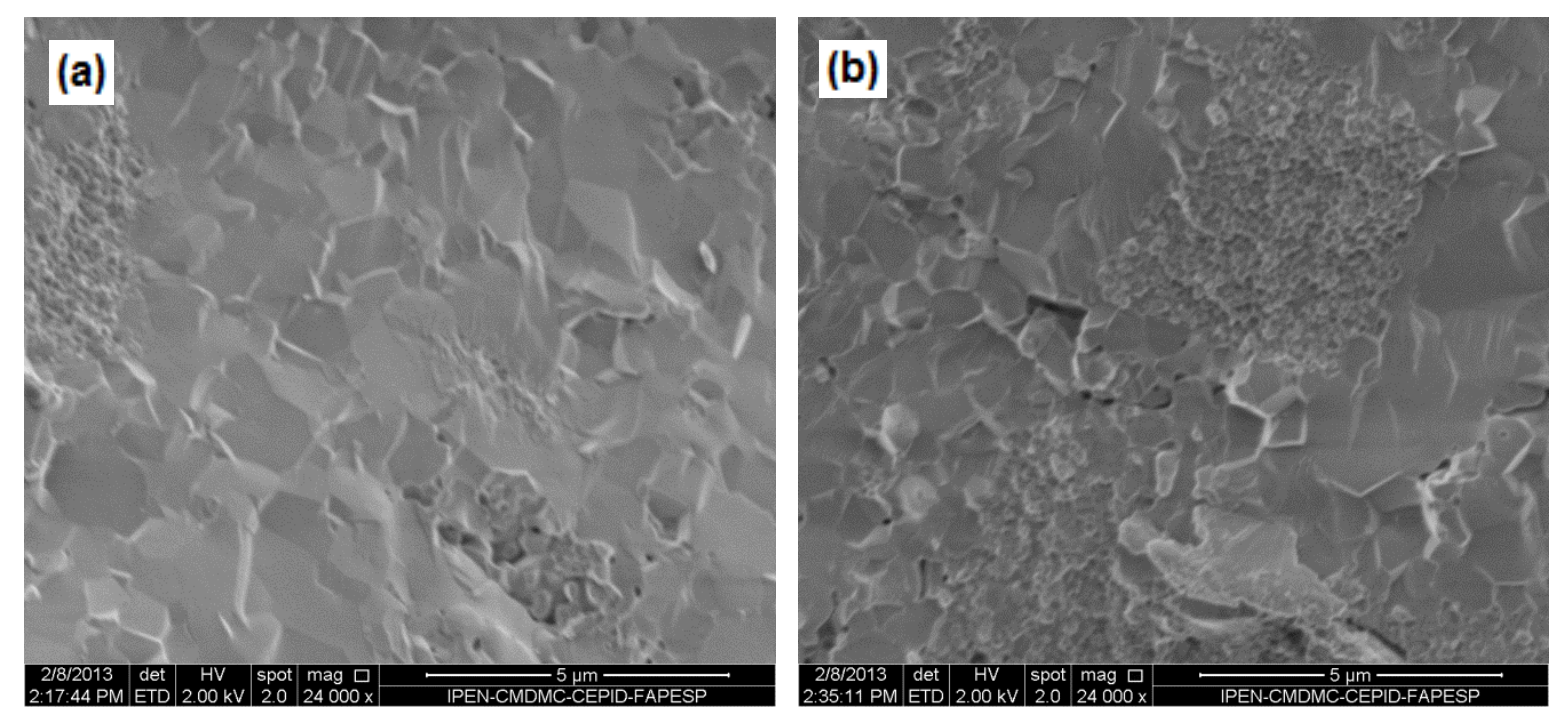

Figura 53. Micrografias da superfície de fratura de amostras de (a) 10Sc1DySZ e (b) $10 \mathrm{Sc} 1 \mathrm{NbSZ}$ sinterizadas a $1450^{\circ} \mathrm{C}$ obtidas por FEG. 


\section{Sinterização Assistida por Campo Elétrico}

Com o objetivo de melhorar a densificação dos compostos sintetizados por coprecipitação, amostras calcinadas foram submetidas à sinterização assistida por campo elétrico. Devido à aplicação simultânea de temperatura e pressão, esse tipo de sinterização permite a utilização de temperaturas mais baixas e tempos muito menores, comparado com a sinterização convencional, produzindo materiais densos com pequeno crescimento de grãos. ${ }^{36,37}$

A Tabela XII lista as condições estudadas por sinterização assistida por campo elétrico, a densidade relativa e a estrutura cristalina encontrada para as amostras de zircônia-escândia contendo 1\% de aditivo. Os experimentos foram realizados variando a temperatura e o tempo de patamar. Elevados valores de densidade relativa foram obtidos na faixa de 1100 a $1400{ }^{\circ} \mathrm{C}$. A estrutura cúbica foi completamente estabilizada somente na amostra contendo Dy.

Tabela XII. Valores de densidade relativa $\left(\rho_{R}\right)$, tamanho médio de grãos $(G)$ e estruturas cristalinas encontradas para amostras de $10 \mathrm{ScSZ}$ contendo $1 \% \mathrm{em} \mathrm{mol}$ de aditivo preparadas por coprecipitação e consolidadas pela técnica de sinterização assistida por campo elétrico em diferentes condições de temperatura (T) e tempo de patamar (t) a $65 \mathrm{MPa}$.

\begin{tabular}{cccccc}
\hline Aditivo & $\mathbf{T}\left({ }^{\circ} \mathbf{C}\right)$ & $\mathbf{t}(\mathbf{m i n})$ & $\boldsymbol{\rho}_{\boldsymbol{R}}(\%)$ & Estrutura* $^{*}$ & $\boldsymbol{G}(\boldsymbol{\mu m})$ \\
\hline $\mathrm{Dy}_{2} \mathrm{O}_{3}$ & 1000 & 4 & $81,6 \pm 0,5$ & $c$ & $0,18 \pm 0,01$ \\
$\mathrm{Dy}_{2} \mathrm{O}_{3}$ & 1100 & 4 & $97,0 \pm 0,2$ & $c$ & $0,81 \pm 0,02$ \\
$\mathrm{Dy}_{2} \mathrm{O}_{3}$ & 1200 & 4 & $97,5 \pm 0,2$ & $c$ & $3,63 \pm 0,36$ \\
$\mathrm{Dy}_{2} \mathrm{O}_{3}$ & 1300 & 4 & $97,5 \pm 0,2$ & $c$ & $4,76 \pm 0,59$ \\
\hline $\mathrm{Nb}_{2} \mathrm{O}_{5}$ & 1200 & 5 & $91,7 \pm 0,2$ & $c+\beta$ & - \\
$\mathrm{Nb}_{2} \mathrm{O}_{5}$ & 1400 & 5 & $95,6 \pm 0,2$ & $c+\beta$ & - \\
\hline
\end{tabular}

${ }^{\star} c=$ cúbica, $\beta=$ romboédrica.

Um aumento significativo na densidade relativa ocorreu com o aumento da temperatura de sinterização de 1000 para $1100^{\circ} \mathrm{C}$ em amostras contendo Dy. Comportamento similar foi obtido para o sistema zircônia-escândia-céria consolidado também por SPS. ${ }^{56,97}$ 
Após sinterização, as amostras ficaram escuras devido à contaminação por carbono. As folhas de grafita utilizadas para proteger o molde e facilitar a extração podem promover a difusão de carbono em altas temperaturas durante o processo de sinterização. ${ }^{97}$ Com a finalidade de promover a eliminação mesmo que parcial de carbono, os compactos sinterizados foram submetidos a tratamento térmico a $900^{\circ} \mathrm{C}$ por 5 min.

A Figura 54 mostra os difratogramas de raios $X$ de amostras sinterizadas antes (Figura 54a) e após tratamento térmico a $900{ }^{\circ} \mathrm{C}$ por 5 min (Figura 54b). Para ambas as composições, houve estabilização da fase cúbica para as condições de sinterização avaliadas. No entanto, para as amostras contendo $\mathrm{Nb}$ foram detectados picos de difração referentes à fase $\beta$. Os picos de difração posicionados a $26,5^{\circ}$ (indicados por *) são atribuídos à grafita com estrutura hexagonal. ${ }^{98}$ Conforme pode ser observado na Figura 54b, após tratamento térmico houve o desaparecimento de picos da fase romboédrica $\beta$ nas amostras contendo $\mathrm{Nb}_{2} \mathrm{O}_{5}$, bem como, 0 desaparecimento do pico de difração da grafita. Nenhuma alteração ocorreu nas amostras contendo Dy. 

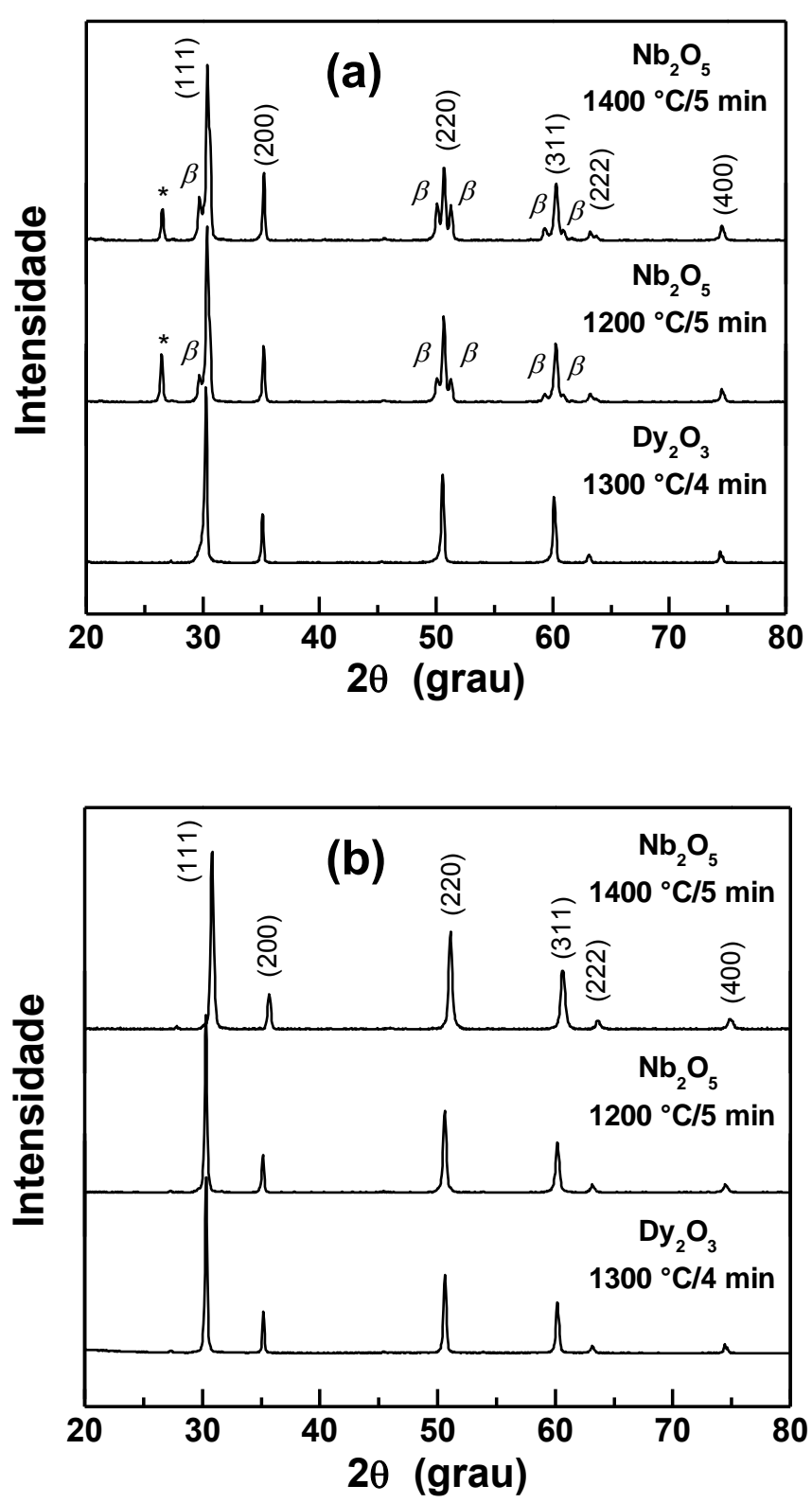

Figura 54. Difratogramas de raios $X$ das amostras após sinterização assistida por campo elétrico. (a) Antes e (b) após tratamento térmico a $900{ }^{\circ} \mathrm{C}$ por 5 min. * Reflexão característica da estrutura cristalina da grafita.

Dessa forma, a fase romboédrica observada nas amostras de 10Sc1NbSZ após a sinterização assistida por campo elétrico pode ter sido originada pela redução de $\mathrm{Nb}^{5+}$, devido à atmosfera redutora durante o experimento.

As micrografias das amostras contendo Dy sinterizadas por SPS são mostradas na Figura 55. 
Pode ser observado para a condição de $1000{ }^{\circ} \mathrm{C}$ por 4 min, na imagem da superfície de fratura (Figura 55a), que a porosidade está distribuída aleatoriamente. O tamanho médio de grãos foi de 0,18 $\mu \mathrm{m}$. Como observado nas micrografias de superfícies polidas e atacadas termicamente, para as condições entre 1100 e $1300{ }^{\circ} \mathrm{C}$ (Figura 55b-d), o aumento da temperatura promoveu o aumento da densidade e tamanho médio dos grãos. Diferente da sinterização convencional, elevada homogeneidade microestrutural foi encontrada a partir da sinterização assistida por campo elétrico. Esse comportamento pode ser atribuído às características do método de sinterização, que possibilita o rápido aquecimento dos compactos, bem como, a aplicação simultânea de temperatura e pressão.
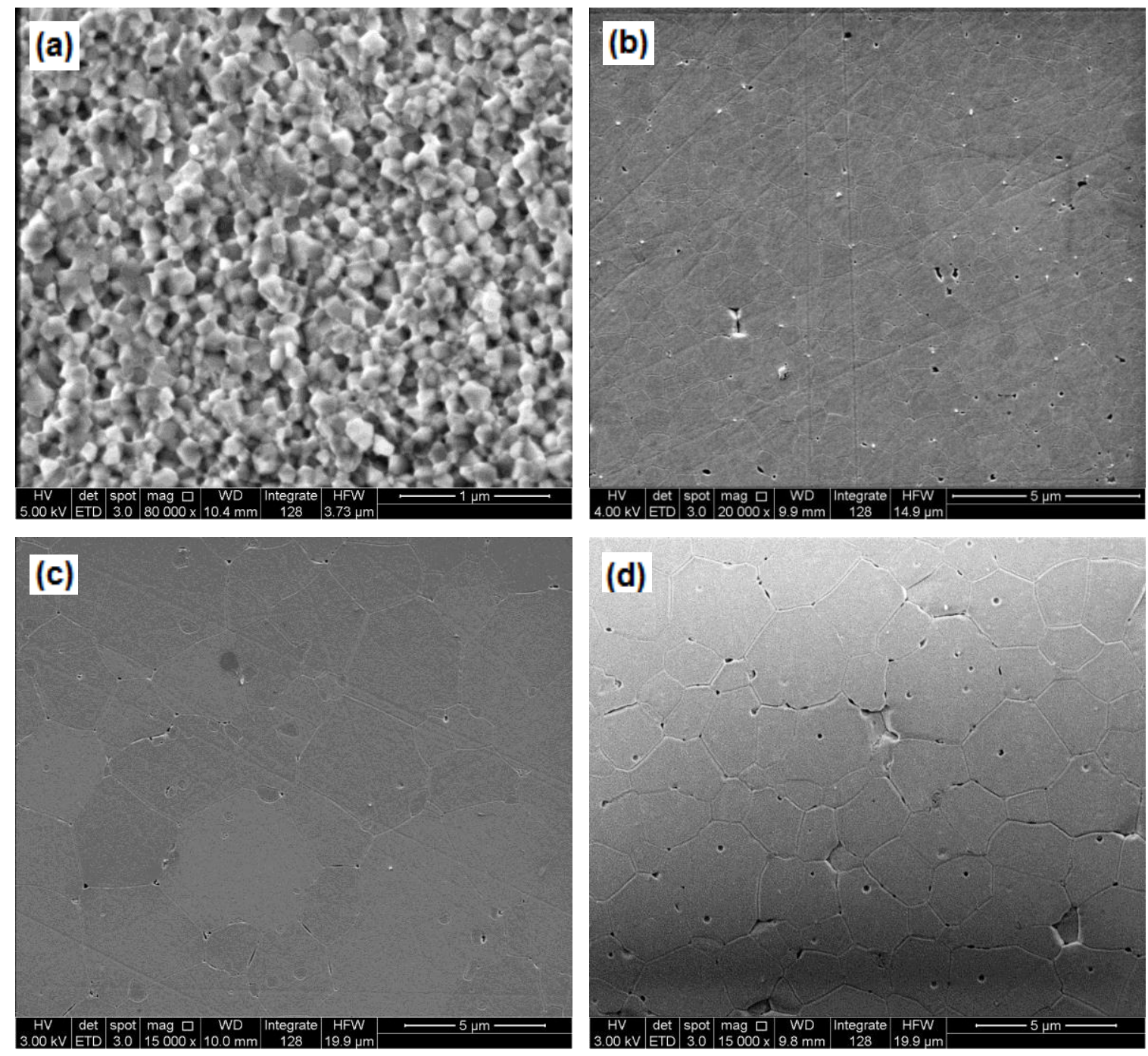

Figura 55. Micrografias de amostras de 10Sc1DySZ sinterizadas por SPS: (a) $1000^{\circ} \mathrm{C}$ por $4 \mathrm{~min}$ (fratura), (b) $1100^{\circ} \mathrm{C}$ por $4 \mathrm{~min}$, (c) $1200{ }^{\circ} \mathrm{C}$ por 4 min e (d) $1300{ }^{\circ} \mathrm{C}$ por 4 min. 
A condutividade elétrica foi analisada por meio da técnica de espectroscopia de impedância. ${ }^{99,100}$ Essa técnica permite, em muitos casos, separar a contribuição do grão (intragranular) e contorno de grãos (intergranular) para a resposta elétrica de materiais policristalinos. Os dados de impedância, $Z^{*}(\omega)$, geralmente são representados no plano complexo ou diagrama de impedância, que consiste em apresentar o oposto da parte imaginária, $-Z Z^{\prime \prime}(\omega)$, em função da parte real, $Z^{\prime}(\omega)$, para cada frequência medida. Os diagramas de impedância podem ser interpretados de acordo com o modelo de circuitos elétricos representando associações de elementos de circuito $R C$ (ResistênciaCapacitância) submetidos a uma diferença de potencial senoidal. Assim, a resposta elétrica pode ser modelada a partir de um circuito elétrico equivalente ou associação de circuitos.

As contribuições do grão e contorno de grãos para a resposta elétrica foram determinadas na região de baixas temperaturas (até aproximadamente $600{ }^{\circ} \mathrm{C}$ ), enquanto que, em altas temperaturas, apenas a condutividade iônica total foi determinada. A evolução dos diagramas de impedância em função da temperatura para uma amostra de $10 \mathrm{Sc} 1 \mathrm{DySZ}$ sinterizada a $1300^{\circ} \mathrm{C}$ por 4 min é apresentada na Figura 56, como exemplo. Os valores de $Z^{\prime}$ e $Z^{\prime \prime}$ foram normalizados pelas dimensões do compacto. Os números nos diagramas representam o logaritmo decimal da frequência. Dois semicírculos bem definidos são observados no diagrama de impedância a $403{ }^{\circ} \mathrm{C}$ na faixa de altas e intermediárias frequências. Acima de $403^{\circ} \mathrm{C}$, embora seja observado apenas um semicírculo bem definido, na região de intermediárias frequências associado ao contorno de grãos, as contribuições intra e intergranular podem ser determinadas separadamente. No entanto, acima de $720^{\circ} \mathrm{C}$, apenas a condutividade elétrica total pode ser determinada.

O efeito bloqueante dos contornos de grão, responsável pelos semicírculos a intermediárias frequências, diminuiu continuamente com 0 aumento da temperatura. Resultados similares foram encontrados para as amostras sinterizadas em baixas temperaturas. Isto já é conhecido da literatura, pois a contribuição do bloqueio exercido pelos contornos de grão em cerâmicas à base de zircônia desaparece a altas temperaturas $\left(\geq 600^{\circ} \mathrm{C}\right) .^{8}$ 


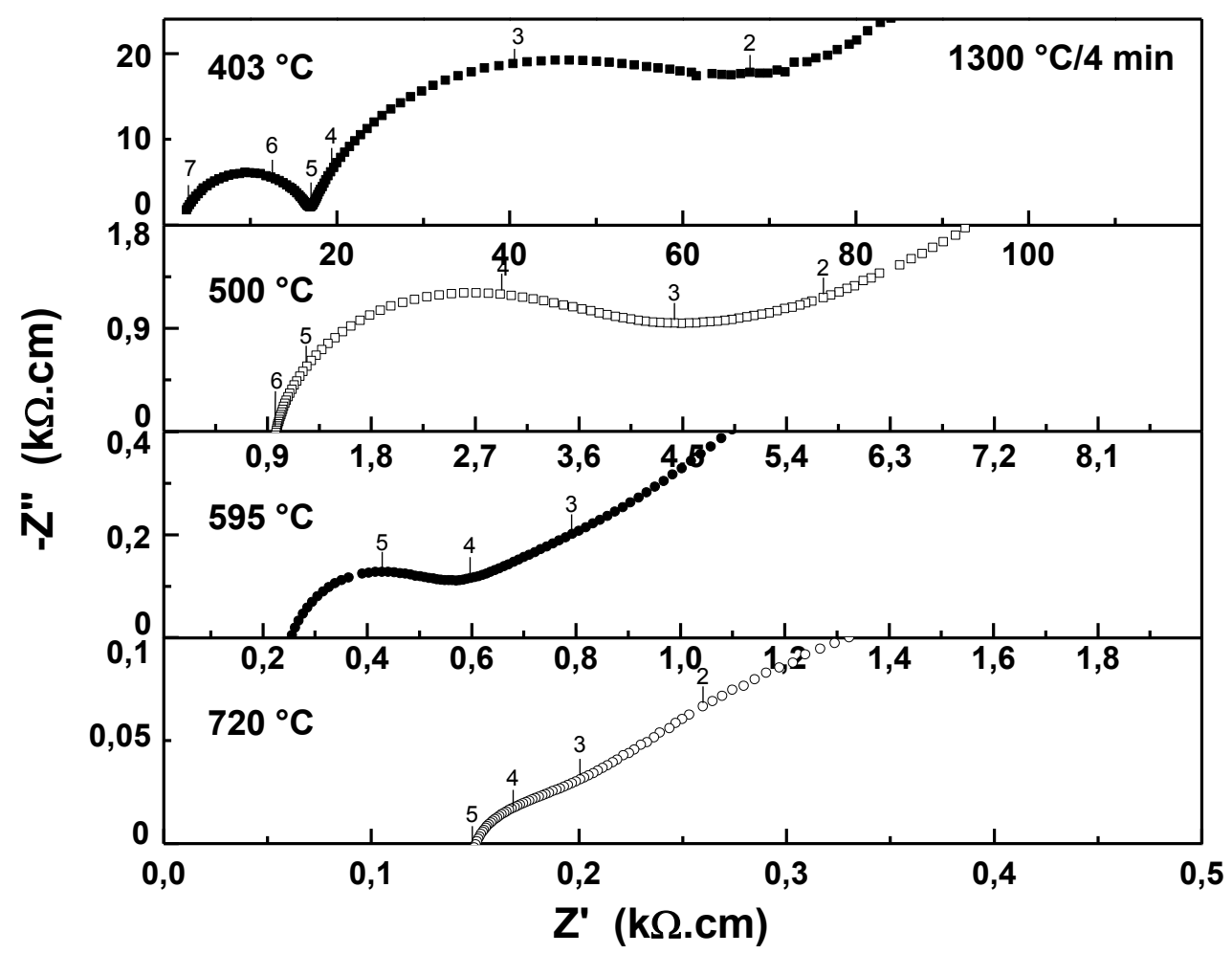

Figura 56. Diagramas de impedância em função da temperatura para uma amostra de 10Sc1DySZ sinterizada a $1300{ }^{\circ} \mathrm{C}$ por $4 \mathrm{~min}$. Os números nos diagramas representam o logaritmo decimal da frequência.

Os gráficos de Arrhenius da condutividade elétrica do grão e contorno de grãos das amostras consolidadas por sinterização assistida por campo elétrico são mostrados na Figura 57. Nenhuma variação significativa da condutividade do grão ocorreu em função da temperatura de sinterização (Figura 57a). A menor condutividade do contorno de grão encontrada para a amostra sinterizada a $1100{ }^{\circ} \mathrm{C}$ (Figura 57b) pode ser associada ao menor tamanho dos grãos. Nenhuma diferença foi observada nos valores de condutividade iônica dos contornos de grão das amostras sinterizadas a 1200 e $1300{ }^{\circ} \mathrm{C}$, evidenciando que a partir de um tamanho médio de grão específico o bloqueio aos portadores de carga nas interfaces é desprezível. Esse comportamento é esperado, pois a diminuição na área ocupada pelo contorno de grãos devido ao aumento de tamanho dos grãos promove a diminuição da resistência elétrica intergranular e, portanto, aumento da condutividade iônica. 

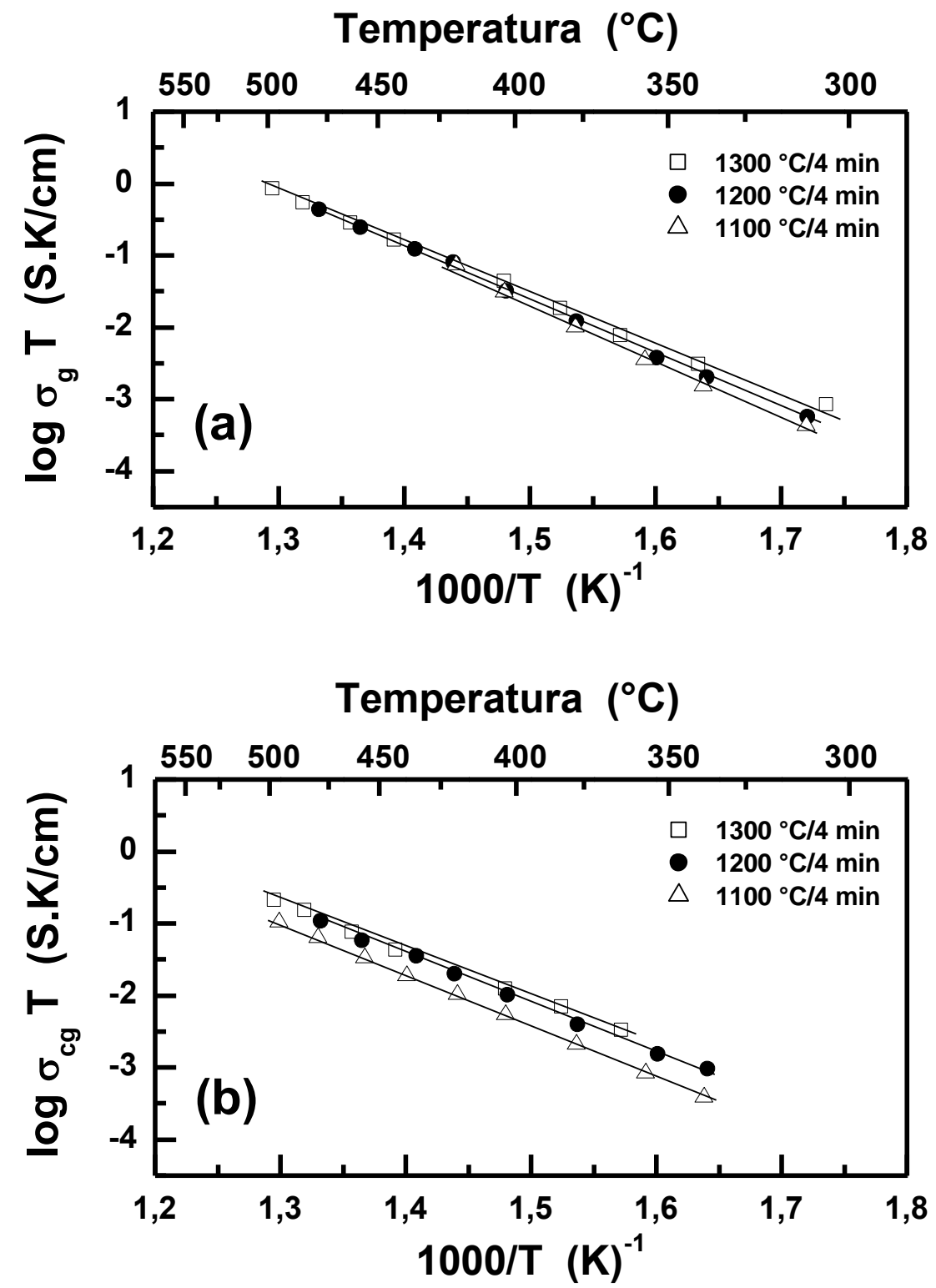

Figura 57. Gráficos de Arrhenius para a condutividade elétrica do (a) grão e (b) contorno de grãos de amostras de 10Sc1DySZ sinterizadas por SPS em diferentes temperaturas.

O gráfico de Arrhenius da condutividade elétrica total de amostras sinterizadas por SPS contendo Dy e $\mathrm{Nb}$ é mostrado na Figura 58. Para comparação, os valores encontrados para uma amostra de 10ScSZ comercial sinterizada a $1550^{\circ} \mathrm{C}$ por $10 \mathrm{~h}$ também é apresentado. 
Em altas temperaturas, todas as amostras avaliadas apresentaram valores de condutividade inferiores ao $10 \mathrm{ScSZ}$, comportamento similar aos resultados reportados para cerâmicas de zircônia-escândia contendo aditivos. ${ }^{5,19,40}$ Contudo, as amostras contendo $\mathrm{Nb}$ apresentam valores de condutividade em altas temperaturas similares aos da zircônia-escândia-céria, que até o momento é o eletrólito sólido ternário com valor mais elevado reportado na literatura. ${ }^{41}$

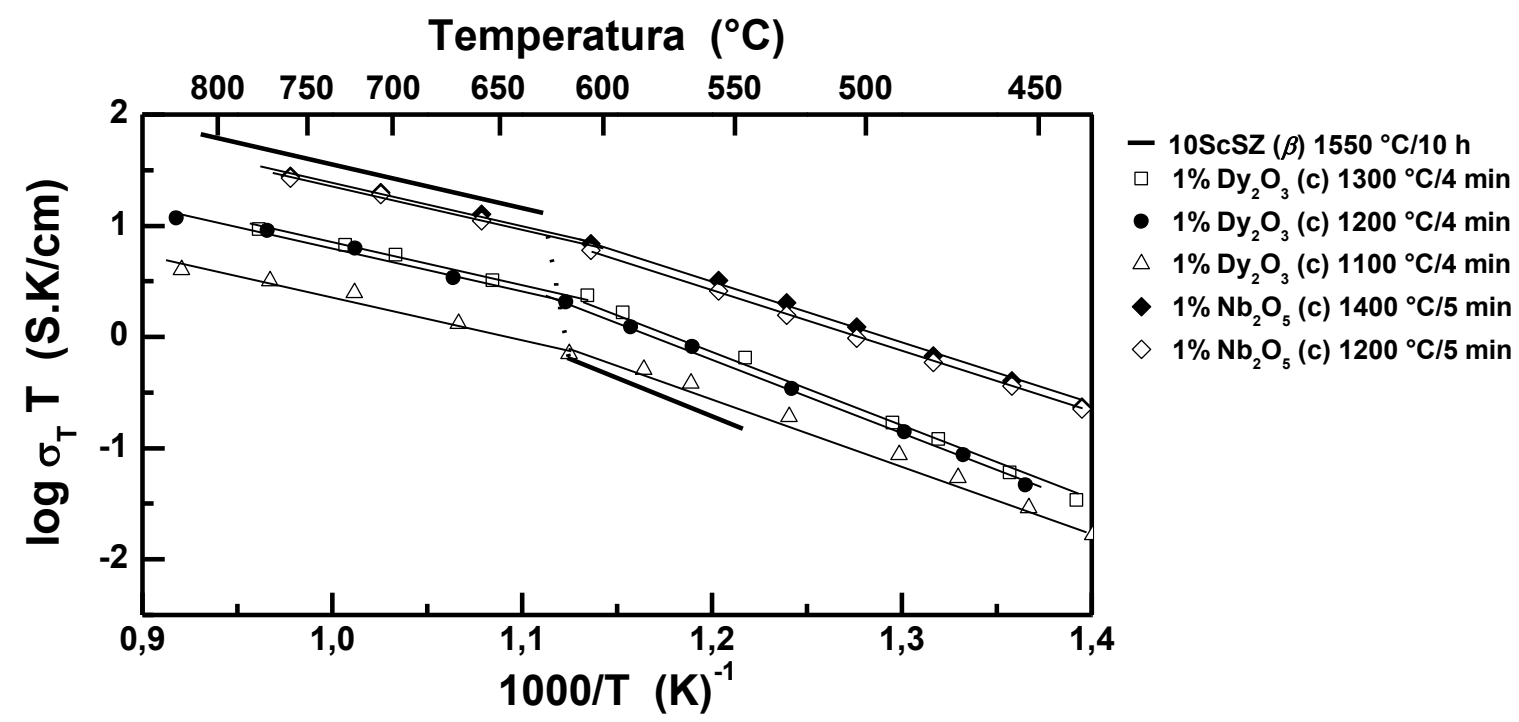

Figura 58. Gráficos de Arrhenius para a condutividade elétrica total de amostras de 10ScSZ comercial sinterizada pelo método convencional, e contendo aditivos preparadas por coprecipitação e sinterizadas por SPS.

Em baixas temperaturas, os maiores valores obtidos para os materiais sinterizados por SPS são atribuídos à estabilização da estrutura cúbica tipo fluorita, a qual possui maior condutividade elétrica em relação à fase romboédrica. As amostras contendo $\mathrm{Nb}$ apresentaram maiores valores de condutividade iônica total. Os valores de energia de ativação para os materiais com e sem aditivos são da ordem de $1,40 \mathrm{eV}$ (até $550{ }^{\circ} \mathrm{C}$ ) e $0,80 \mathrm{eV}$ (entre 550 e $800^{\circ} \mathrm{C}$ ), e estão de acordo com aqueles já reportados. ${ }^{39,45,48}$ 


\section{Mistura de Óxidos}

Serão apresentados os resultados da caracterização dos materiais precursores, bem como, de amostras sinterizadas.

Caracterização dos Óxidos Precursores

As imagens, obtidas por microscopia eletrônica de varredura, dos materiais precursores como recebidos utilizados nas sínteses por mistura de óxidos são mostradas na Figura 59. A zircônia contendo $10 \%$ mol de escândia comercial (Figura 59a) apresenta partículas nanométricas. Enquanto que $\bigcirc \quad \mathrm{Dy}_{2} \mathrm{O}_{3}$ (Figura 59b) é constituído por partículas e/ou aglomerados de partículas com

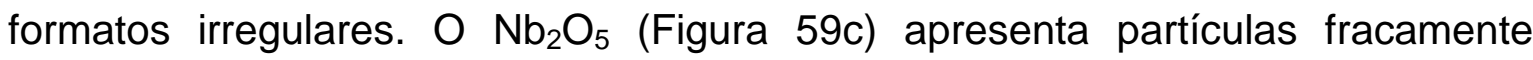
aglomeradas.

Os difratogramas de raios $X$ dos materiais de partida como recebidos são mostrados nas Figuras 60-62. A identificação das estruturas cristalinas foi feita por comparação com as fichas PDF indicadas nas Figuras. O 10ScSZ (Figura 60) apresenta estrutura romboédrica $\beta$ à temperatura ambiente. $\mathrm{O} \mathrm{Dy}_{2} \mathrm{O}_{3}$ (Figura 61) possui estrutura cúbica (grupo espacial la-3) tipo $\mathrm{C}$ característica dos óxidos de terras raras. ${ }^{60} \mathrm{O} \mathrm{Nb}_{2} \mathrm{O}_{5}$ (Figura 62) possui estrutura monoclínica (grupo espacial P2). A introdução de óxidos aditivos ao sistema zircônia-escândia pode estabilizar a fase cúbica de maior condutividade iônica. 

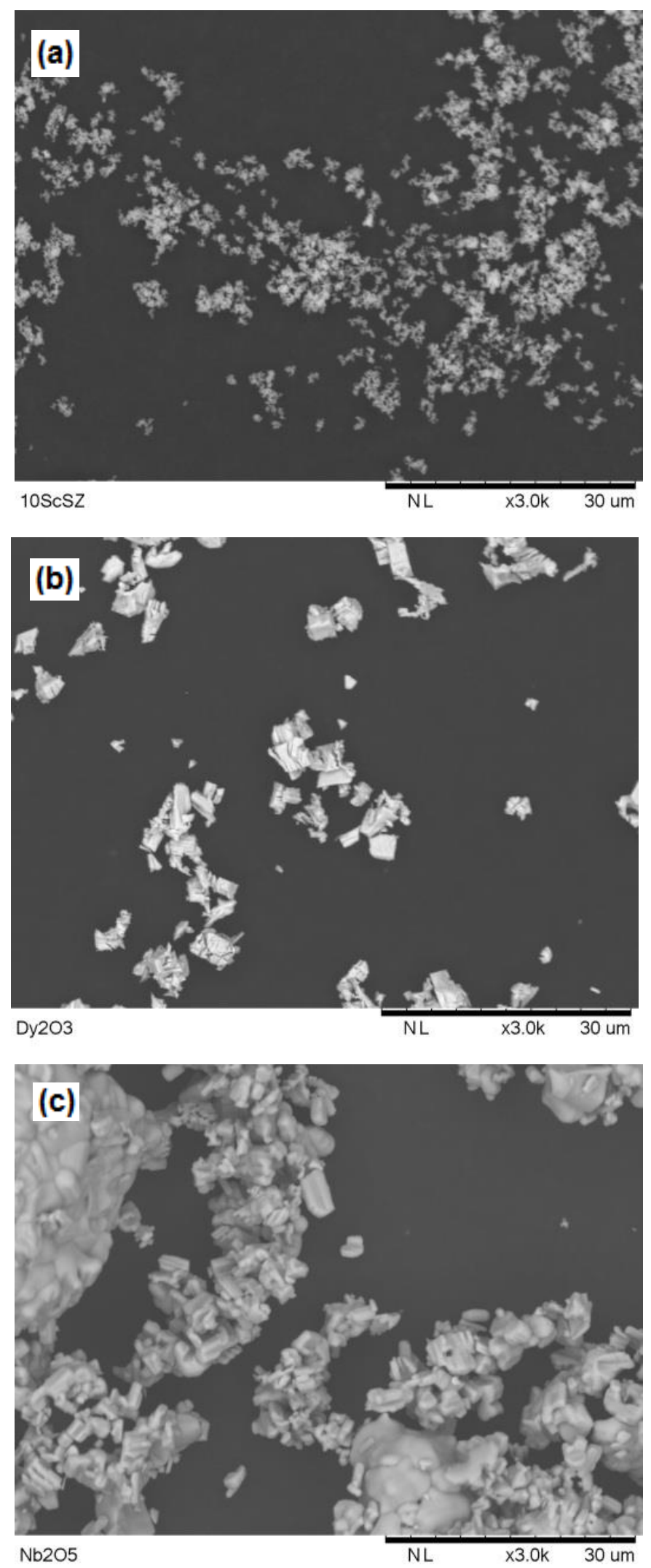

Figura 59. Micrografias, obtidas por microscópio eletrônico de varredura, dos pós de (a) 10ScSZ, (b) $\mathrm{Dy}_{2} \mathrm{O}_{3}$ e (c) $\mathrm{Nb}_{2} \mathrm{O}_{5}$. 


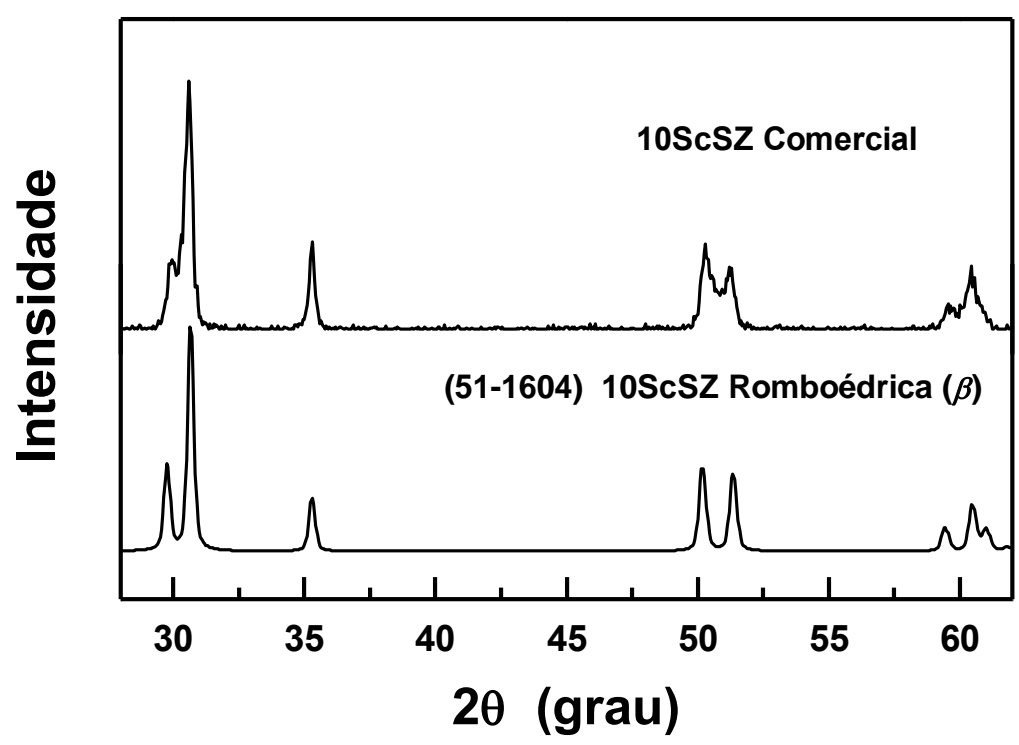

Figura 60. Difratogramas de raios $X$ do pó de zircônia-escândia ( $10 \% \mathrm{~mol}$ ) como recebido (superior) e 10ScSZ na fase romboédrica $\beta$ de acordo com a ficha PDF 51-1604 (inferior).

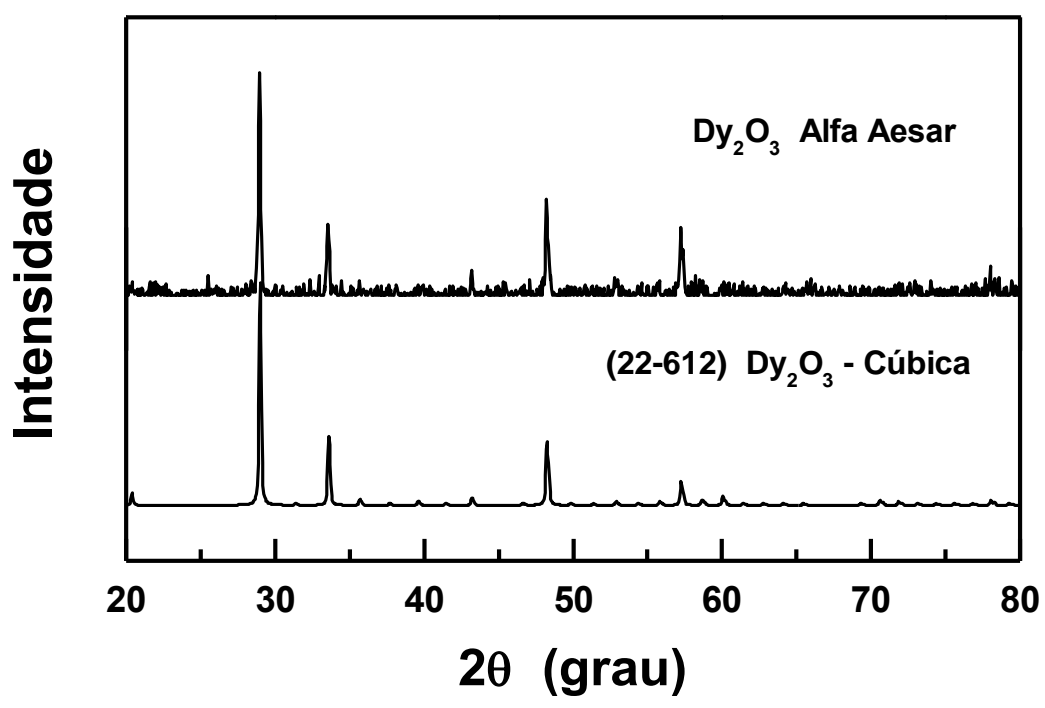

Figura 61. Difratogramas de raios $X$ do pó de $\mathrm{Dy}_{2} \mathrm{O}_{3}$ como recebido (superior), e do óxido de disprósio de acordo com a ficha PDF 22-612 (inferior). 


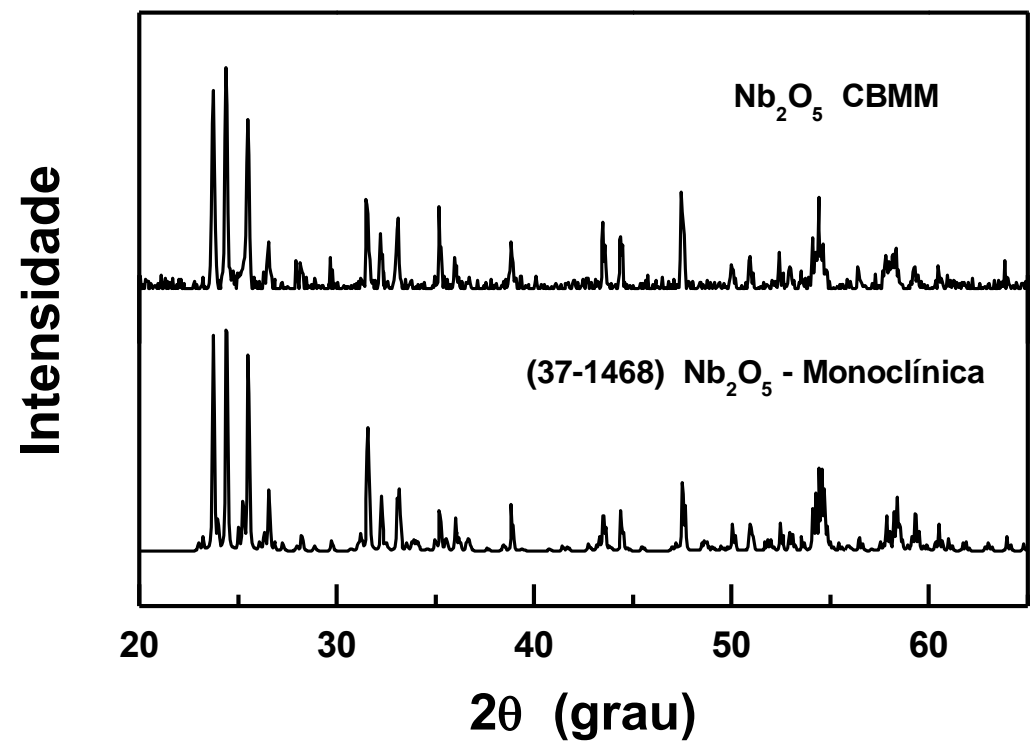

Figura 62. Difratogramas de raios $\mathrm{X}$ do pó de $\mathrm{Nb}_{2} \mathrm{O}_{5}$ como recebido (superior) e do óxido de nióbio (V) de acordo com a ficha PDF 37-1468 (inferior).

Caracterização dos Compactos

A Tabela XIII lista as condições de sinterização avaliadas, a densidade relativa e a estrutura cristalina determinada por difração de raios $\mathrm{X}$ para as composições estudadas contendo $\mathrm{Dy}_{2} \mathrm{O}_{3}$ preparadas por mistura de óxidos.

O aumento do teor do aditivo promoveu diminuição da densidade. As densidades relativas foram de aproximadamente 96,94 e $92 \%$ para as composições de 1; 1,5 e $2 \% \mathrm{~mol}$, respectivamente. Esse comportamento estabelece um limite no teor deste aditivo para fins de aplicação. Para cada composição, o aumento da temperatura e/ou do tempo de patamar não apresentou influência significativa na densidade. No entanto, as condições de sinterização apresentam forte influência na estrutura cristalina dos materiais à base de ScSZ ${ }^{39,55}$ A estrutura cúbica da zircônia-escândia foi completamente estabilizada a partir da adição de $1,5 \%$ de $\mathrm{Dy}_{2} \mathrm{O}_{3}$. 
Tabela XIII. Valores de densidade relativa $\left(\rho_{R}\right)$ e estruturas cristalinas encontradas para amostras de 10ScSZ contendo diferentes teores molares de $\mathrm{Dy}_{2} \mathrm{O}_{3}$ preparadas por mistura de óxidos e sinterizadas em diferentes temperaturas $(\mathrm{T})$ e tempos de patamar $(\mathrm{t})$.

\begin{tabular}{|c|c|c|c|}
\hline $\mathbf{T}\left({ }^{\circ} \mathbf{C}\right)$ & $t(h)$ & $\rho_{R}(\%)$ & Estrutura* \\
\hline \multicolumn{4}{|c|}{$0 \%$} \\
\hline 1550 & 10 & $97,5 \pm 0,9$ & $\beta$ \\
\hline \multicolumn{4}{|c|}{$1 \%$} \\
\hline 1500 & 5 & $95,6 \pm 0,5$ & $c+\beta$ \\
\hline 1500 & 10 & $97,0 \pm 0,5$ & $c+\beta$ \\
\hline 1550 & 2 & $95,4 \pm 0,5$ & $c+\beta$ \\
\hline 1550 & 10 & $96,7 \pm 0,6$ & $c+\beta$ \\
\hline \multicolumn{4}{|c|}{$1,5 \%$} \\
\hline 1500 & 5 & $94,1 \pm 0,6$ & $c+\beta$ \\
\hline 1550 & 10 & $94,5 \pm 0,7$ & $c$ \\
\hline \multicolumn{4}{|c|}{$2 \%$} \\
\hline 1500 & 5 & $92,3 \pm 0,4$ & $c$ \\
\hline 1500 & 10 & $91,6 \pm 0,7$ & $c$ \\
\hline 1550 & 2 & $92,1 \pm 0,5$ & $c+\beta$ \\
\hline 1550 & 10 & $91,4 \pm 0,8$ & $c$ \\
\hline
\end{tabular}

${ }^{*} C=$ cúbica, $\beta=$ romboédrica.

Embora o mecanismo de estabilização da fase cúbica ainda não seja bem compreendido, foi reportado que a formação da fase romboédrica $\beta$ depende da temperatura e do tempo de patamar de sinterização. ${ }^{39,55}$

Os difratogramas de raios $\mathrm{X}$ de amostras sinterizadas de 10ScSZ contendo diferentes teores de $\mathrm{Dy}_{2} \mathrm{O}_{3}$ são mostrados na Figura 63. A adição de $1 \%$ (Figura 63a) promoveu a estabilização parcial da fase cúbica na $10 \mathrm{ScSZ}$. Isto mostra que o Dy auxilia na estabilização da fase de maior condutividade iônica da zircônia-escândia. Com o aumento do teor do aditivo para 1,5 e $2 \%$ ocorreu a completa estabilização da estrutura cúbica (Figura 63b), que é dependente também do tempo de patamar de sinterização. 

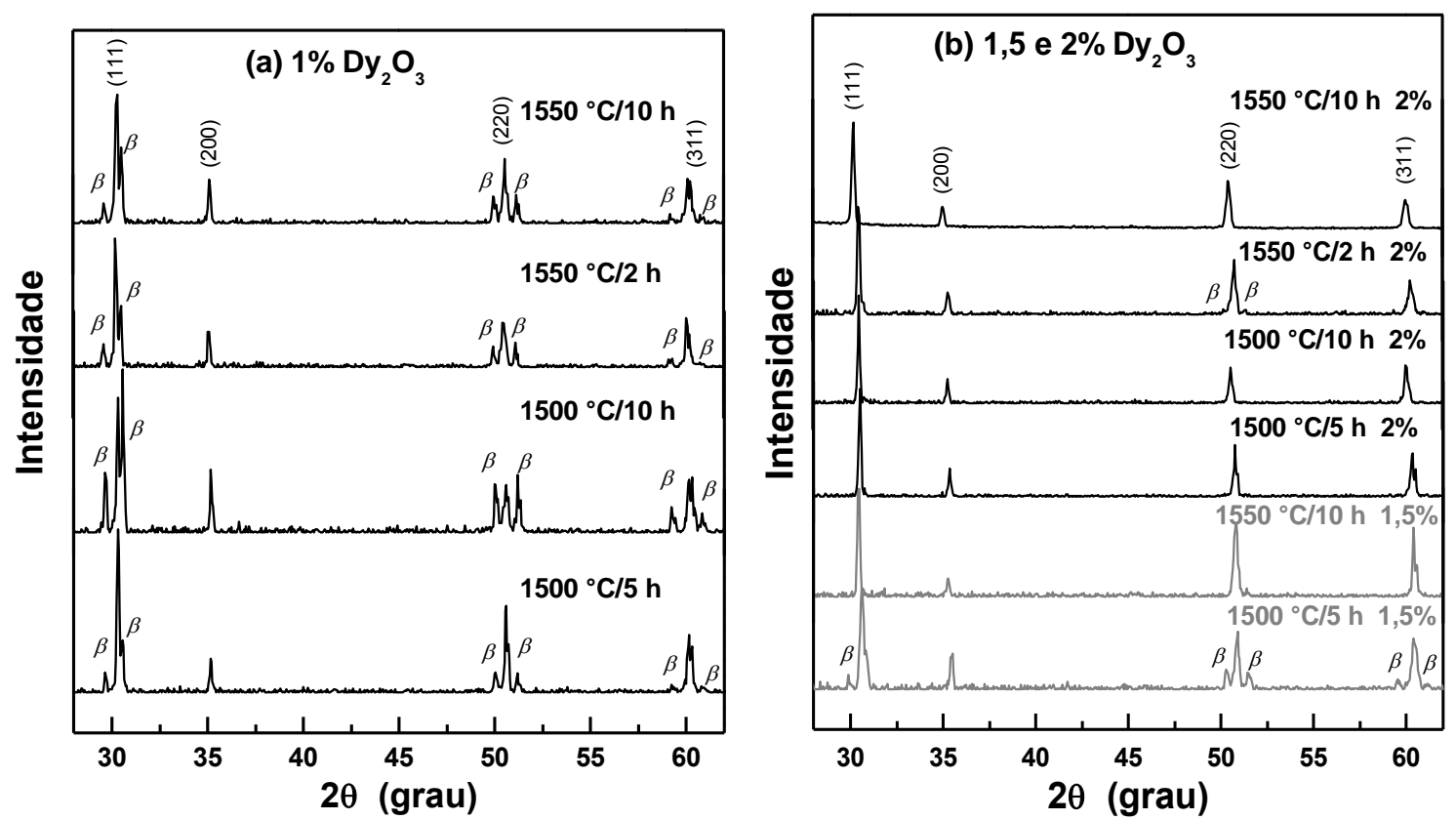

Figura 63. Difratogramas de raios $X$ das amostras de $10 S c S Z$ contendo (a) $1 \%$ e (b) 1,5 e $2 \%$ em mol de $\mathrm{Dy}_{2} \mathrm{O}_{3}$.

Nas amostras preparadas por coprecipitação o teor mínimo de $\mathrm{Dy}_{2} \mathrm{O}_{3}$ para estabilização total da fase cúbica foi de $1 \%$, enquanto que para as amostras preparadas por reação em estado sólido, nas mesmas condições de sinterização, o teor mínimo foi de $2 \%$. Estes resultados revelam que a estabilização da fase cúbica pela introdução do aditivo ( $\mathrm{Nb}$ ou $\mathrm{Dy}$ ) é facilitada quando se utiliza um método químico. Isto pode estar associado com a maior solubilidade do aditivo na matriz devido ao tamanho muito reduzido (nanométrico) das partículas precipitadas.

Alguns autores mostraram que pode haver a formação de fases secundárias apenas na superfície de materiais à base de zircônia-escândia. ${ }^{101}$ Dessa forma, com o objetivo de avaliar se houve formação de fase romboédrica apenas na superfície do material, uma das faces de uma amostra de 10Sc1DySZ sinterizada a $1550{ }^{\circ} \mathrm{C}$ por $10 \mathrm{~h}$, a qual apresentou significativo teor de fase $\beta$ (Figura 63a), foi desbastada. Os difratogramas de raios $X$ antes e após desbaste são mostrados na Figura 64. Os picos de difração demarcados por c e $\beta$ estão relacionados com as estruturas cúbica e romboédrica, respectivamente. Nenhuma alteração significativa em relação ao teor das fases foi observada. Este resultado mostra que a fase $\beta$ permanece em todo o volume da amostra. 


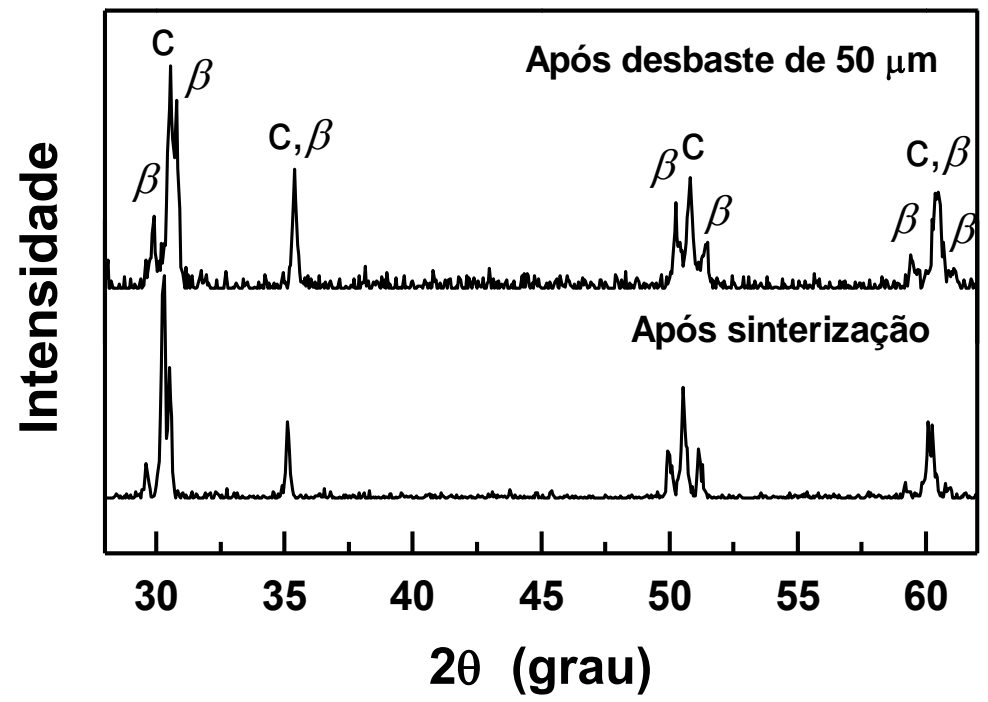

Figura 64. Difratogramas de raios $X$ de uma amostra de 10Sc1DySZ sinterizada a $1550{ }^{\circ} \mathrm{C}$ por $10 \mathrm{~h}$ antes e após desbaste de $50 \mu \mathrm{m}$.

A Tabela XIV lista as condições de sinterização avaliadas, a densidade relativa e a estrutura cristalina determinada por difração de raios $X$ para as composições estudadas contendo $\mathrm{Nb}_{2} \mathrm{O}_{5}$ preparadas por mistura de óxidos. $\mathrm{O}$ mesmo comportamento foi encontrado para as amostras contendo $\mathrm{Dy}_{2} \mathrm{O}_{3}$ preparadas pelo método convencional, o aumento do teor do aditivo diminuiu a densidade dos compactos. As amostras contendo $1 \%$ em mol de $\mathrm{Nb}_{2} \mathrm{O}_{5}$ também apresentaram densidades relativas em torno de $96 \%$ após sinterizações a $1500{ }^{\circ} \mathrm{C}$. A fase cúbica foi completamente estabilizada a partir da adição molar de apenas $0,5 \%$, teor inferior em relação ao $\mathrm{Dy}_{2} \mathrm{O}_{3}(1,5 \%)$. Isso pode ser explicado com base na temperatura de fusão do $\mathrm{Nb}_{2} \mathrm{O}_{5}$. Enquanto que $\circ \mathrm{Dy}_{2} \mathrm{O}_{3}$ apresenta temperatura de fusão superior a $2400{ }^{\circ} \mathrm{C}$, a do $\mathrm{Nb}_{2} \mathrm{O}_{5}$ é de $1512^{\circ} \mathrm{C}$. Dessa forma, nas condições de sinterização avaliadas, a partir de $1500{ }^{\circ} \mathrm{C}$, provavelmente ocorreu a formação da fase líquida do aditivo, facilitando a difusão de íons $\mathrm{Nb}^{5+}$ na zircônia-escândia, favorecendo a formação da solução sólida e consequentemente a estabilização da estrutura cúbica.

Outro fator que auxilia a formação de solução sólida neste caso é o raio iônico do $\mathrm{Nb}^{5+}$, que é inferior ao raio do Zr. Assim, para o $\mathrm{Nb}$, o teor mínimo para estabilização da fase cúbica $(0,5 \%)$ independe do método de síntese, enquanto que para o Dy a estabilização de fase acontece para 1 ou $1,5 \%$ dependendo do método de síntese. 
No caso do Dy, o qual possui raio iônico superior ao raio do $\mathrm{Zr}^{4+}$ e alto ponto de fusão na forma de óxido, o método de síntese exerce papel importante na estabilização de fases, visto que partículas nanoestruturadas apresentam solubilidade aumentada quando comparadas com partículas micrométricas.

Tabela XIV. Valores de densidade relativa $\left(\rho_{R}\right)$ e estruturas cristalinas encontradas para amostras de zircônia-escândia contendo diferentes teores molares de $\mathrm{Nb}_{2} \mathrm{O}_{5}$ preparadas por mistura de óxidos e sinterizadas em diferentes temperaturas $(\mathrm{T})$ e tempos de patamar $(\mathrm{t})$.

\begin{tabular}{cccc}
\hline $\mathbf{T}\left({ }^{\circ} \mathbf{C}\right)$ & $\mathbf{t}(\mathbf{h})$ & $\boldsymbol{\rho}_{\boldsymbol{R}}(\%)$ & Estrutura $^{*}$ \\
\hline \multicolumn{4}{c}{$0,25 \%$} \\
\hline 1500 & 5 & $98,1 \pm 0,5$ & $c+\beta$ \\
1550 & 2 & $98,4 \pm 0,6$ & $c+\beta$ \\
1550 & 10 & $98,0 \pm 0,8$ & $c+\beta$ \\
\hline \multicolumn{4}{c}{$0,5 \%$} \\
\hline 1500 & 5 & $97,7 \pm 0,5$ & $c$ \\
1550 & 10 & $97,9 \pm 0,6$ & $c$ \\
\hline \multicolumn{5}{c}{$1 \%$} \\
1400 & 2 & $86,8 \pm 0,3$ & $c+\beta$ \\
1500 & 2 & $95,7 \pm 0,3$ & $c$ \\
1500 & 5 & $95,0 \pm 1,2$ & $c$ \\
\hline
\end{tabular}

${ }^{*} C=$ cúbica, $\beta=$ romboédrica.

Os valores de densidade relativa, apresentados nas Tabelas XIII e XIV, foram calculados com base na densidade teórica da fase predominante, cúbica $\left(5,7 \mathrm{~g} / \mathrm{cm}^{3}\right)$ ou romboédrica $\beta\left(5,65 \mathrm{~g} / \mathrm{cm}^{3}\right) .{ }^{13}$

Os difratogramas de raios $X$ de amostras sinterizadas de 10ScSZ contendo diferentes teores de $\mathrm{Nb}_{2} \mathrm{O}_{5}$ são mostrados na Figura 65. A fase cúbica foi parcialmente estabilizada com apenas $0,25 \%$ de nióbia (Figura 65a). A estabilização total da fase cúbica foi obtida a partir de $0,5 \%$ de $\mathrm{Nb}_{2} \mathrm{O}_{5}$. Da mesma forma que para a disprósia, a estabilização da fase cúbica é dependente das condições de sinterização. Para o teor molar de 1\% (Figura 65b), apenas para a condição de sinterização de $1400{ }^{\circ} \mathrm{C}$ por $2 \mathrm{~h}$ foi observada a fase secundária $\beta$. No entanto, o compacto apresentou densidade relativa inferior a $90 \%$. 

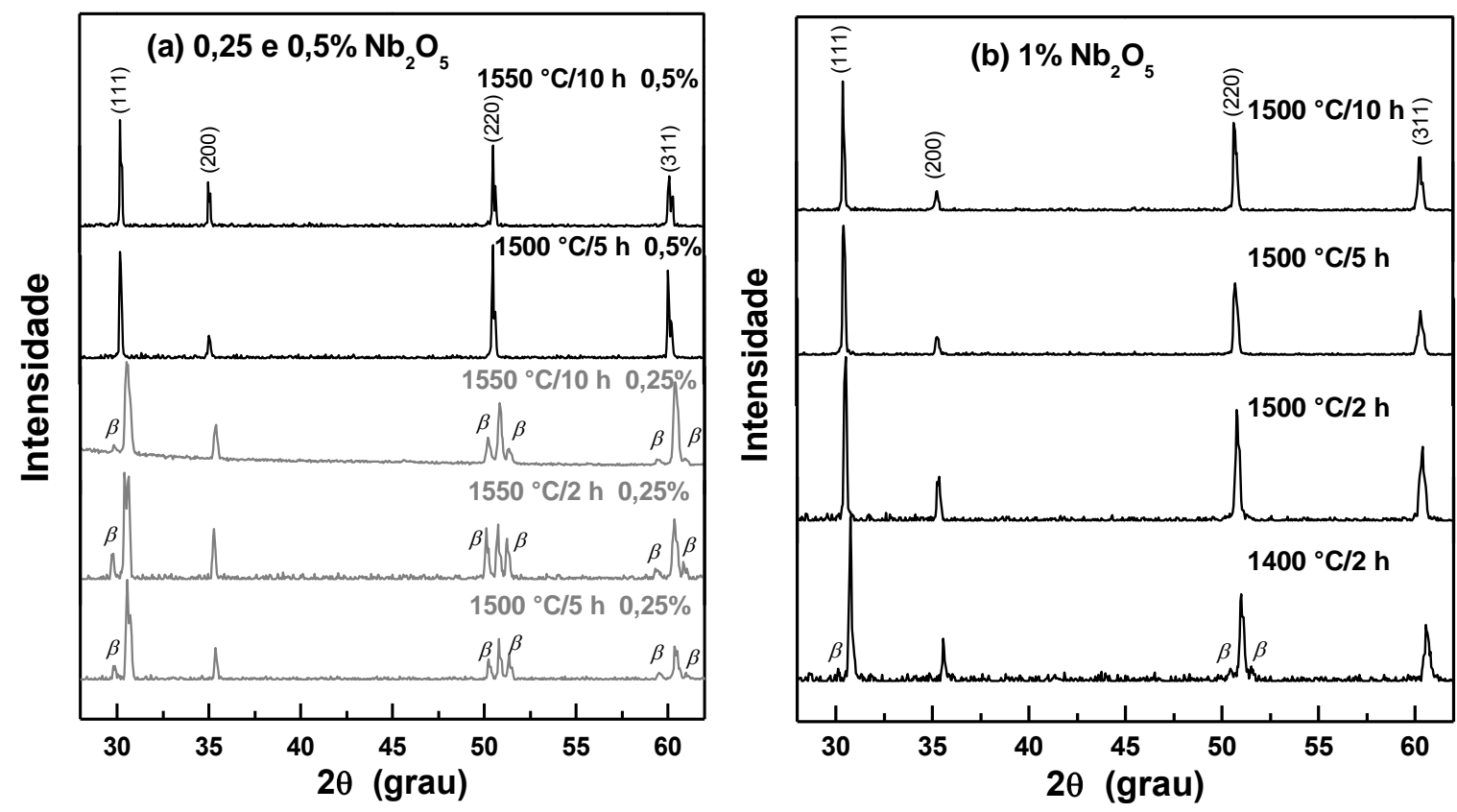

Figura 65. Difratogramas de raios $X$ das amostras de 10ScSZ contendo (a) 0,25 e $0,5 \%$ e (b) $1 \%$ em mol de $\mathrm{Nb}_{2} \mathrm{O}_{5}$.

As micrografias de amostras de $10 \mathrm{ScSZ}$ sinterizada a $1550{ }^{\circ} \mathrm{C}$ por $10 \mathrm{~h}$ (sem aditivo) e $1500{ }^{\circ} \mathrm{C}$ por $5 \mathrm{~h}$ contendo 1,5 e $2 \%$ em mol de disprósia são mostradas na Figura 66. O 10ScSZ sem aditivo apresentou grãos com estrutura tipo "herringbone" (Figura 66a). Esse tipo de efeito microestrutural foi reportado para o sistema zircônia-escândia e é atribuído à fase romboédrica $\beta .{ }^{17} \mathrm{O}$ material contendo $1,5 \%$ de disprósia apresentou grãos com características semelhantes, evidenciados na Figura 66b e em destaque na Figura 66c. Por outro lado, em amostras contendo $2 \%$ do aditivo nenhum efeito microestrutural relacionado à fase $\beta$ foi evidenciado. Esses resultados estão de acordo com os difratogramas de raios $X$ (Figura 63), onde é possível perceber amostras sinterizadas a $1500{ }^{\circ} \mathrm{C}$ por $5 \mathrm{~h}$ apresentam ambas as fases cúbica e $\beta$, para teores de 1,5\% em mol de $\mathrm{Dy}_{2} \mathrm{O}_{3}$, enquanto que a adição de $2 \%$ promove a completa estabilização da fase cúbica à temperatura ambiente. 

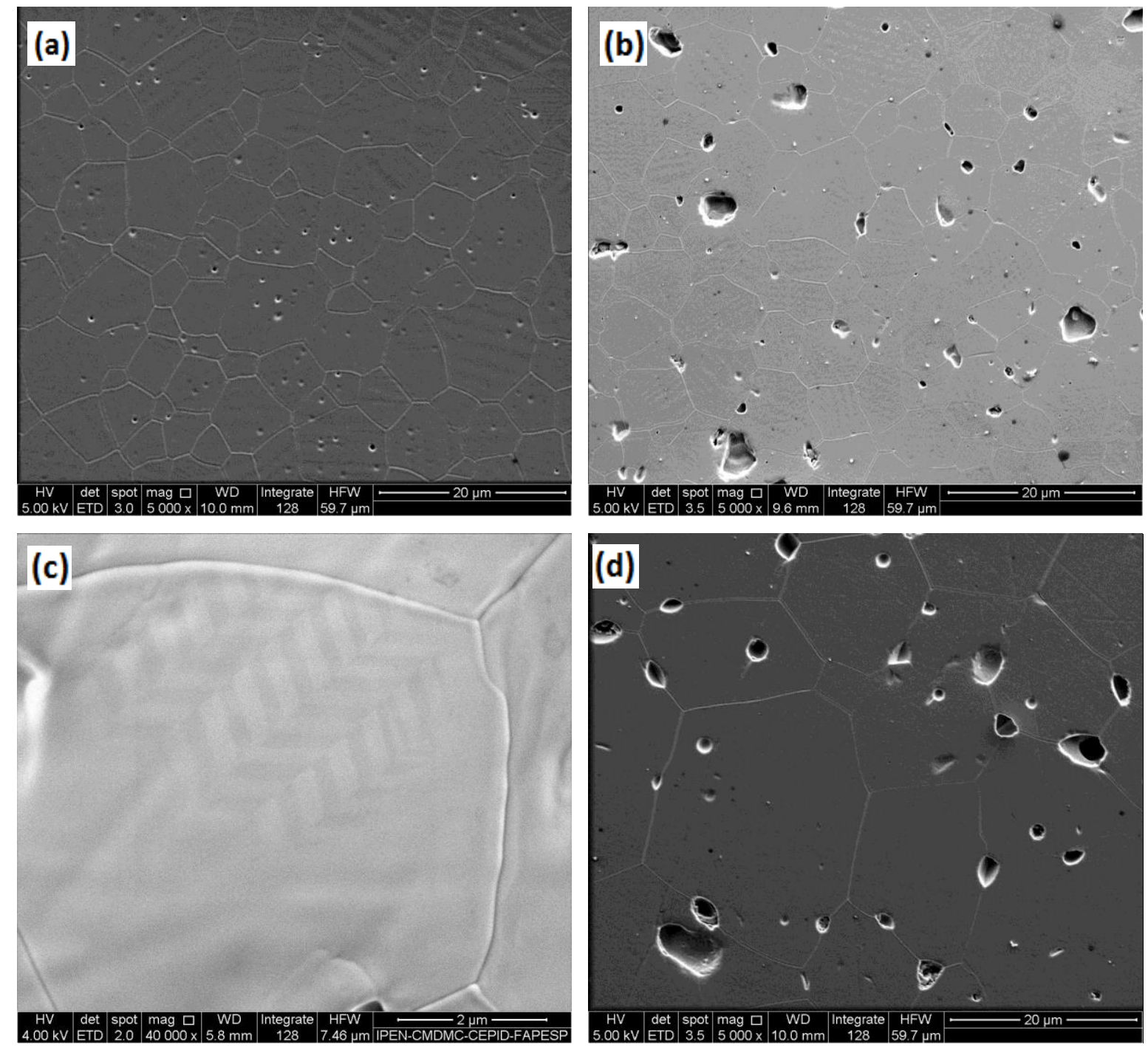

Figura 66. Micrografias obtidas por microscópio eletrônico de varredura de amostras de $10 \mathrm{ScSZ}$ (a) sem aditivos e sinterizada a $1550^{\circ} \mathrm{C}$ por $10 \mathrm{~h}$ e sinterizadas a $1500{ }^{\circ} \mathrm{C}$ por $5 \mathrm{~h}$ contendo diferentes teores molares de $\mathrm{Dy}_{2} \mathrm{O}_{3}:$ (b) $1,5 \%$, (c) $1,5 \%$ e (d) $2 \%$.

As micrografias de $10 \mathrm{ScSZ}$ contendo diferentes teores de $\mathrm{Nb}_{2} \mathrm{O}_{5}$ sinterizadas a $1500{ }^{\circ} \mathrm{C}$ por $5 \mathrm{~h}$ são mostradas na Figura 67 . Grãos arredondados podem ser observados nas micrografias, sendo mais evidente para maiores concentrações de $\mathrm{Nb}_{2} \mathrm{O}_{5}$. Essa característica sugere a formação da fase líquida do $\mathrm{Nb}_{2} \mathrm{O}_{5}$ mencionada anteriormente. Dessa forma, a presença de poros é menos pronunciada nas amostras contendo esse aditivo. 

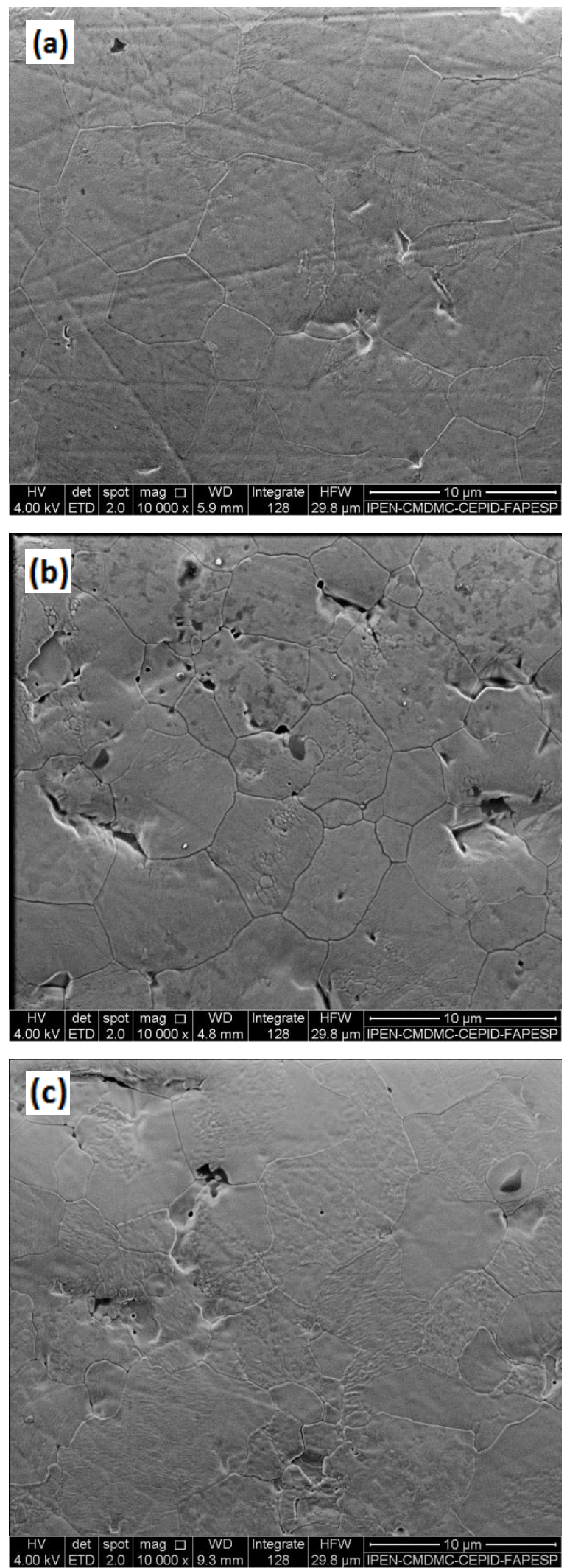

Figura 67. Micrografias obtidas por microscópio eletrônico de varredura de amostras de 10ScSZ sinterizadas a $1500{ }^{\circ} \mathrm{C}$ por $5 \mathrm{~h}$ contendo diferentes teores molares de $\mathrm{Nb}_{2} \mathrm{O}_{5}$ : (a) $0,25 \%$, (b) $0,5 \%$ e (c) $1 \%$. 
A Figura 68 mostra o gráfico de Arrhenius da condutividade elétrica total para amostras de $10 \mathrm{ScSZ}$ contendo os teores molares de 1 e $2 \%$ de $\mathrm{Dy}_{2} \mathrm{O}_{3}$ sinterizadas a $1500{ }^{\circ} \mathrm{C}$ por $5 \mathrm{~h}$. A estrutura cristalina encontrada para cada amostra está indicada entre parênteses. Para comparação, o gráfico de Arrhenius de $10 \mathrm{ScSZ}$ comercial sem aditivo, sinterizado a $1550^{\circ} \mathrm{C}$ por $10 \mathrm{~h}$, novamente é apresentado. $\mathrm{O}$ salto da condutividade por volta de $600^{\circ} \mathrm{C}$ é observado na curva sem aditivo. Da mesma forma, para o $10 \mathrm{ScSZ}$ contendo $1 \%$ de $\mathrm{Dy}_{2} \mathrm{O}_{3}$, há uma mudança na inclinação entre 500 e $600{ }^{\circ} \mathrm{C}$. Esses comportamentos são atribuídos à transição de fase cúbica-romboédrica característica do ScSZ. ${ }^{5}$ A ligeira diminuição da temperatura de transição de fase pode ser atribuída ao teor inferior de fase $\beta$ em compactos com aditivo (Figura 63a).

Por outro lado, o $10 \mathrm{ScSZ}$ contendo $2 \%$ de $\mathrm{Dy}_{2} \mathrm{O}_{3}$, com estrutura cúbica à temperatura ambiente (Figura 63b), apresentou uma única inclinação no intervalo de temperatura investigado, similar às amostras de 10Sc1DySZ sintetizadas por coprecipitação e sinterizadas por SPS (Figura 58). Esses resultados confirmam que a adição de $2 \%$ em mol de disprósia, sintetizada por mistura de óxidos, promove a supressão da transição de fase. A partir de $600{ }^{\circ} \mathrm{C}$, os valores de energia de ativação encontrados para amostras contendo 1 e $2 \%$ de $\mathrm{Dy}_{2} \mathrm{O}_{3}$ foram de 1,45 e 1,35 eV, respectivamente. Na região de alta temperatura, o aumento do teor de aditivo promoveu a diminuição da condutividade elétrica. 


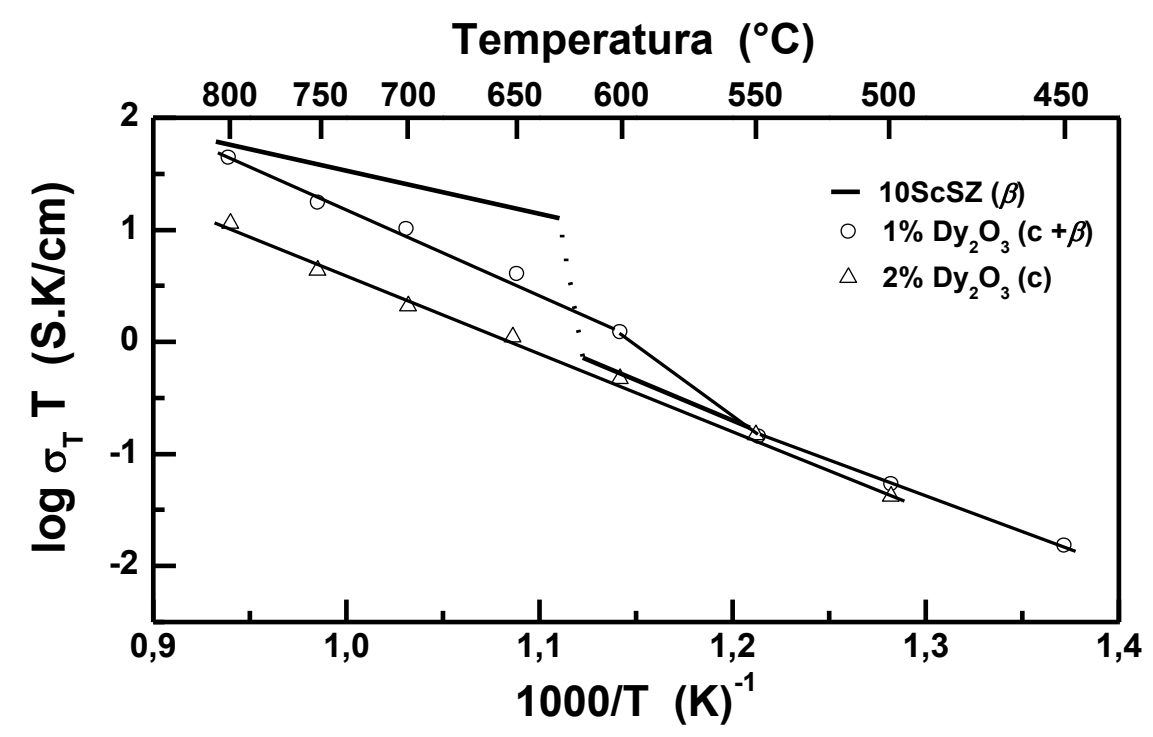

Figura 68. Gráfico de Arrhenius para a condutividade elétrica total de amostras de 10ScSZ, sem aditivo sinterizada a $1550{ }^{\circ} \mathrm{C}$ por $10 \mathrm{~h}$, e contendo $1 \mathrm{e}$ $2 \%$ em mol de $\mathrm{Dy}_{2} \mathrm{O}_{3}$ sinterizadas a $1500{ }^{\circ} \mathrm{C}$ por $5 \mathrm{~h}$.

O gráfico de Arrhenius da condutividade elétrica total para amostras de 10Sc2DySZ sinterizadas a diferentes condições é apresentado na Figura 69. Duas inclinações são observadas para amostras com estrutura cristalina cúbica parcialmente estabilizada, sinterizadas a $1550^{\circ} \mathrm{C}$ por $2 \mathrm{~h}$. O aumento do tempo de patamar de 5 para $10 \mathrm{~h}$, em amostras sinterizadas a $1500{ }^{\circ} \mathrm{C}$, promoveu $\mathrm{O}$ aumento da condutividade elétrica total. De modo geral, em cerâmicas sinterizadas pelo método convencional, o aumento do tempo de patamar promove o aumento do tamanho dos grãos. Dessa forma, o aumento da condutividade elétrica total é esperado, uma vez que há diminuição na área ocupada pelos contornos de grão decorrente do aumento dos grãos com a consequente diminuição da resistência elétrica intergranular. No entanto, as energias de ativação encontradas para os gráficos de Arrhenius a partir de $600{ }^{\circ} \mathrm{C}$ foram semelhantes da ordem de 1,40 eV. 


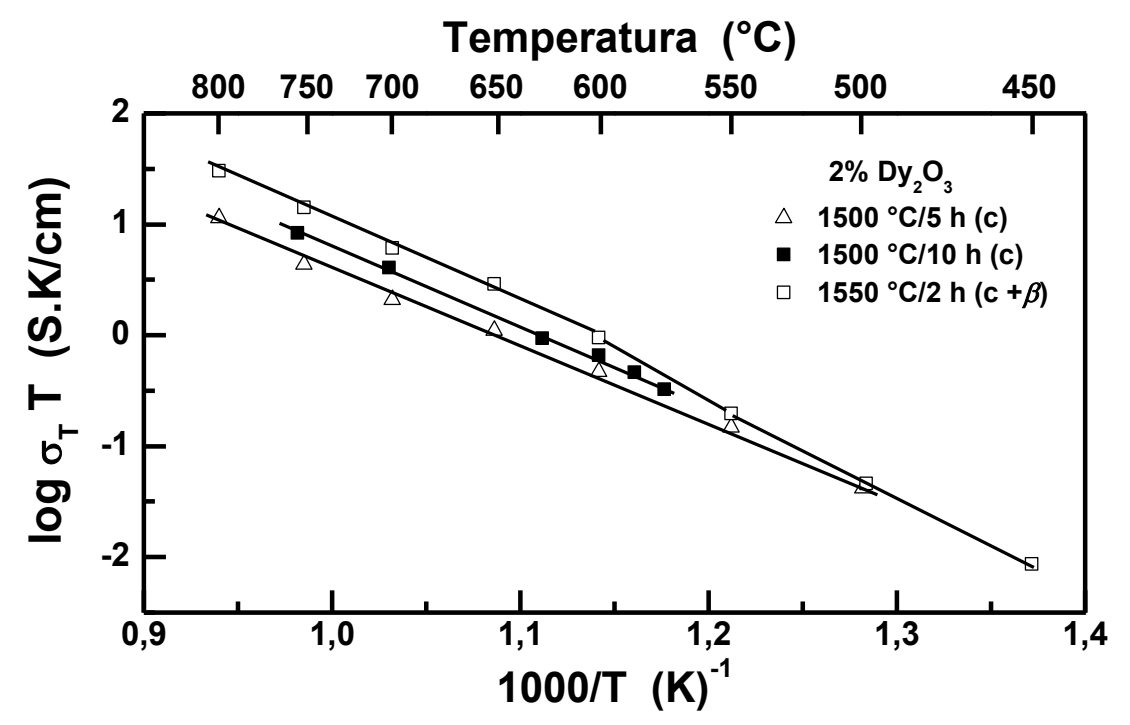

Figura 69. Gráfico de Arrhenius para a condutividade elétrica total de amostras de 10ScSZ contendo $2 \%$ em mol de $\mathrm{Dy}_{2} \mathrm{O}_{3}$ sinterizadas em diferentes condições.

A Figura 70 mostra 0 gráfico de Arrhenius da condutividade elétrica total para amostras de $10 \mathrm{ScSZ}$ contendo diferentes teores molares de $\mathrm{Nb}_{2} \mathrm{O}_{5}$ sinterizadas a $1500{ }^{\circ} \mathrm{C}$ por $5 \mathrm{~h}$. $\mathrm{O}$ aumento de 0,25 para $1 \%$ promoveu um ligeiro aumento da condutividade. No entanto, um aumento significativo da condutividade elétrica total ocorreu com a adição molar de $0,5 \%$ de $\mathrm{Nb}_{2} \mathrm{O}_{5}$ para valores compatíveis com a condutividade do $10 \mathrm{ScSZ}$ sem aditivo. Os materiais contendo $1 \%$ de $\mathrm{Nb}_{2} \mathrm{O}_{5}$ sinterizados por SPS apresentaram condutividade semelhante ao $10 \mathrm{Sc} 0.5 \mathrm{NbSZ}$ até $600^{\circ} \mathrm{C}$.

As energias de ativação encontradas para as amostras contendo 0,25 e 1\% de $\mathrm{Nb}_{2} \mathrm{O}_{5}$ são da ordem de $1,20 \mathrm{eV}$, enquanto que, para o teor molar de $0,5 \%$ foram obtidos valores próximos a $0,80 \mathrm{eV}$ (acima de $600{ }^{\circ} \mathrm{C}$ ) e $1,40 \mathrm{eV}$ (até $600^{\circ} \mathrm{C}$ ), similar ao $10 \mathrm{ScSZ}$ sem aditivos. 


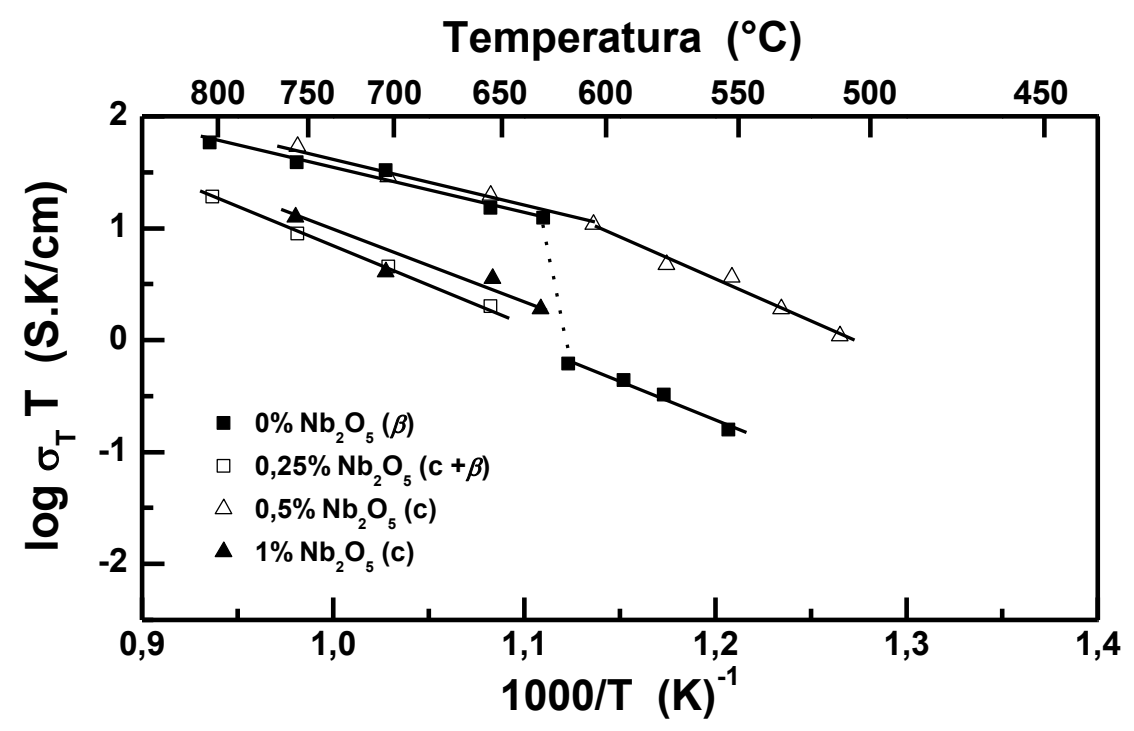

Figura 70. Gráfico de Arrhenius para a condutividade elétrica total de amostras de 10ScSZ, sem aditivo sinterizada a $1550^{\circ} \mathrm{C}$ por $10 \mathrm{~h}$, e contendo 0,25 ; 0,5 e $1 \%$ em mol de $\mathrm{Nb}_{2} \mathrm{O}_{5}$ sinterizadas a $1500{ }^{\circ} \mathrm{C}$ por $2 \mathrm{~h}$.

Convém ressaltar que todos os aditivos reportados até o momento, que estabilizaram a fase cúbica no $10 \mathrm{ScSZ}$ resultaram em valores de condutividade iônica inferiores ao da amostra sem aditivos, na região de altas temperaturas.

Os resultados de envelhecimento térmico a $600{ }^{\circ} \mathrm{C}$ revelam a estabilidade da condutividade iônica, até 170 horas, de amostras de 10ScSZ contendo 0,5\% em mol de $\mathrm{Nb}_{2} \mathrm{O}_{5}$ sinterizadas a $1500{ }^{\circ} \mathrm{C}$ por $5 \mathrm{~h}$, como pode ser observado na curva de condutividade em função do tempo na Figura 71 . Nenhum pico de difração da fase $\beta$ foi identificado nos difratogramas de raios $X$ na faixa de 48 a 54ㅇ (Figura 72).

Isso mostra que a adição de $0,5 \% \mathrm{em}$ mol de $\mathrm{Nb}_{2} \mathrm{O}_{5}$ promove a estabilização da fase cúbica à temperatura ambiente com valores de condutividade similares ao $10 \mathrm{ScSZ}$ sem aditivos com elevada estabilidade durante um período de tempo de $170 \mathrm{~h}$ sob atmosfera de ar. Embora mais estudos precisam ser realizados, principalmente, sob atmosfera redutoras, esses resultados preliminares indicam que o $10 \mathrm{Sc} 0.5 \mathrm{NbSZ}$ é um forte candidato para aplicações como eletrólito sólido em SOFC. 


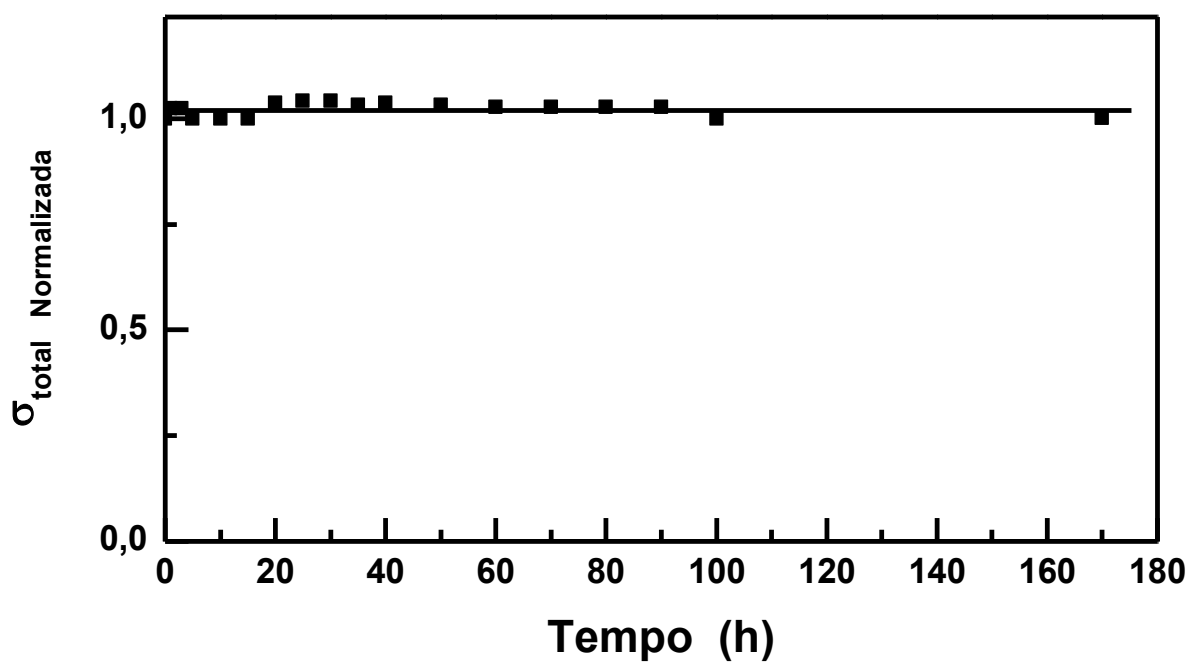

Figura 71. Valores de condutividade elétrica total normalizada em função do tempo após envelhecimento térmico a $600{ }^{\circ} \mathrm{C}$ para amostras de $10 \mathrm{Sc} 0.5 \mathrm{NbSZ}$ sinterizadas a $1500^{\circ} \mathrm{C}$ por $5 \mathrm{~h}$.
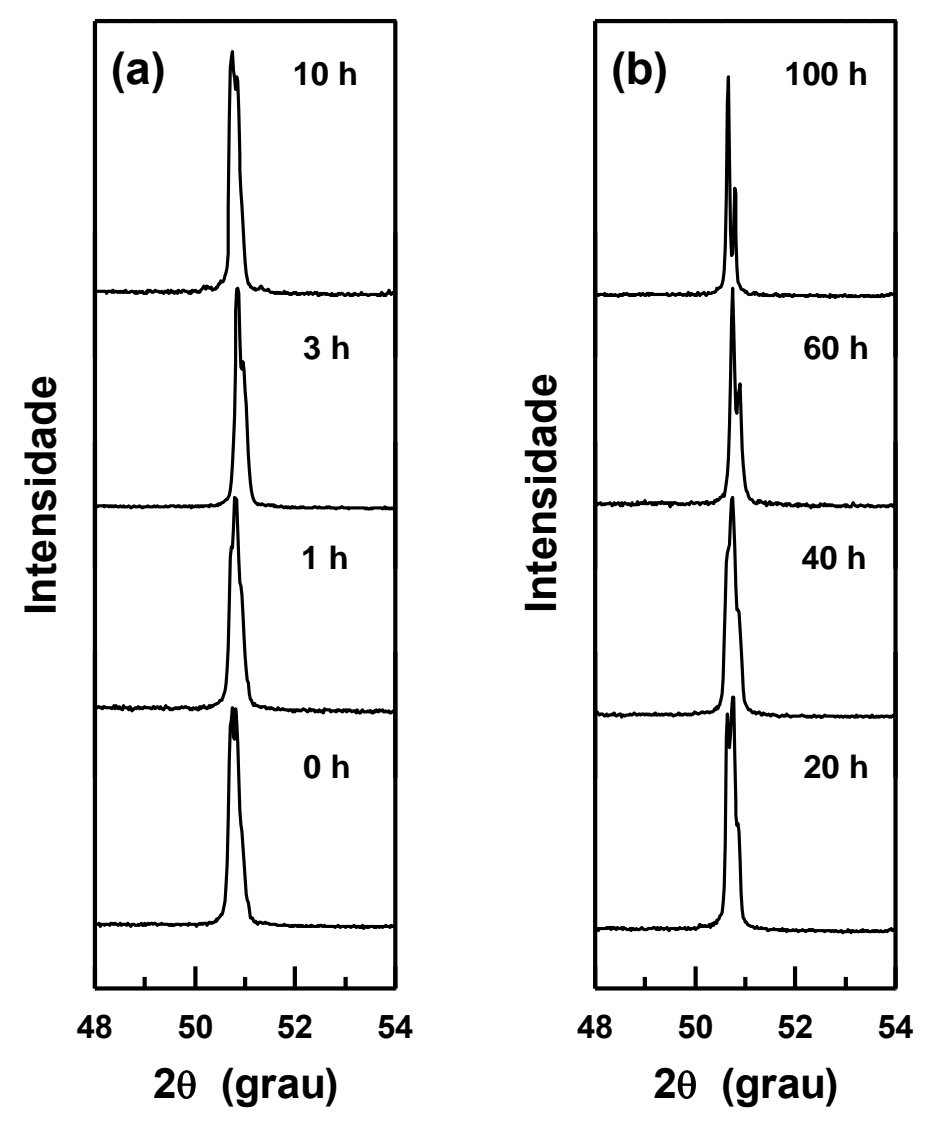

Figura 72. Difratogramas de raios $X$ de amostras de $10 \mathrm{Sc} 0.5 \mathrm{NbSZ}$ submetidas à $600{ }^{\circ} \mathrm{C}$ por várias horas. (a) $0 \mathrm{a} 10 \mathrm{~h}$; (b) $20 \mathrm{a} 100 \mathrm{~h}$. 


\section{CONCLUSÕES}

As microanálises por sonda eletrônica revelaram boa homogeneidade de soluções sólidas nanoparticuladas de zircônia contendo 0 a $20 \% \mathrm{~mol}$ de escândia sintetizadas por coprecipitação de hidróxidos.

O diagrama de fases em nanoescala de tamanho de partícula-composição foi determinado com base em dados termodinâmicos obtidos pelas técnicas de microcalorimetria de adsorção de água e calorimetria à alta temperatura para as

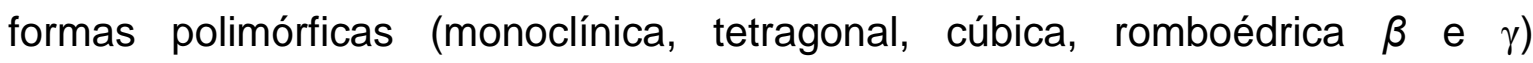
encontradas por difração de raios $\mathrm{X}$.

$\mathrm{A}$ adição de $\mathrm{Dy}_{2} \mathrm{O}_{3}$ e $\mathrm{Nb}_{2} \mathrm{O}_{5}$ à zircônia contendo $10 \%$ em mol de escândia promoveu a estabilização da fase cúbica à temperatura ambiente. A estabilização total da fase cúbica depende do teor do aditivo e das condições de tratamentos térmicos.

Os resultados de análise térmica, difração de raios $X$ e espectroscopia na região do infravermelho indicam que a calcinação dos precursores, sintetizados por coprecipitação, a $500^{\circ} \mathrm{C}$ por $2 \mathrm{~h}$ é adequada para decompor termicamente 0 precursor e formar a fase cúbica em condições ambientes. No entanto, a densificação dos materiais sintetizados por via úmida foi prejudicada pela elevada aglomeração das partículas nanométricas que ocorre durante a síntese.

Amostras densas (> 95\%) de zircônia-escândia contendo os aditivos, sintetizadas pelo método de coprecipitação, foram obtidas somente após serem submetidas à sinterização assistida por campo elétrico.

Para as composições preparadas pelo método convencional de mistura de óxidos, o aumento dos teores dos aditivos promoveu a diminuição da densidade relativa. Os resultados de difração de raios $X$ mostraram que é necessária uma seleção cuidadosa das condições de sinterização para obtenção do material cúbico monofásico à temperatura ambiente. 
Nas amostras preparadas por coprecipitação o teor mínimo de $\mathrm{Dy}_{2} \mathrm{O}_{3}$ para estabilização total da fase cúbica foi de $1 \%$, enquanto que para as amostras preparadas por reação em estado sólido, nas mesmas condições de sinterização, o teor mínimo foi de $2 \%$. Estes resultados revelam que a estabilização da fase cúbica pela introdução do aditivo ( $\mathrm{Nb}$ ou $\mathrm{Dy}$ ) é facilitada quando se utiliza um método químico. Esse comportamento foi atribuído a maior solubilidade do aditivo na matriz com tamanho nanométrico das partículas precipitadas.

Por outro lado, para ambos os métodos de síntese, a estabilização completa da fase cúbica ocorreu a partir de $0,5 \%$ de $\mathrm{Nb}_{2} \mathrm{O}_{5}$. O menor teor de $\mathrm{Nb}_{2} \mathrm{O}_{5}$ necessário para a estabilização da fase foi atribuído à provável formação da fase líquida durante a sinterização (mistura de óxidos) e ao menor tamanho do íon $\mathrm{Nb}^{5+}$ em relação ao $\mathrm{Zr}^{4+}$.

Os resultados de difratometria de raios $X$ em alta temperatura e análise térmica mostraram que houve supressão da transição cúbica-romboédrica $\beta$ em amostras totalmente estabilizadas à temperatura ambiente. A entalpia molar de transição de fase $c-\beta$ encontrada para o $10 \mathrm{ScSZ}$ foi de $1,28 \mathrm{~kJ} / \mathrm{mol}$.

A descontinuidade da condutividade iônica do $10 S c S Z$ observada no gráfico de Arrhenius é atribuída à transição de fase $c-\beta$. A eliminação da descontinuidade foi encontrada para amostras com estrutura cúbica totalmente estabilizada à temperatura ambiente. $\mathrm{O}$ aumento do teor de $\mathrm{Dy}_{2} \mathrm{O}_{3}$ promoveu a diminuição da condutividade iônica. As amostras contendo $0,5 \%$ mol de $\mathrm{Nb}_{2} \mathrm{O}_{5}$ apresentaram valores de condutividade iônica similares aos do $10 \mathrm{ScSZ}$ sem aditivos em uma ampla faixa de temperatura com elevada estabilidade em um período de $170 \mathrm{~h}$ a $600^{\circ} \mathrm{C}$. A condutividade iônica, a $600{ }^{\circ} \mathrm{C}$, do $10 \mathrm{ScSZ}$ é da ordem de $0,5 \mathrm{mS} / \mathrm{cm}$ enquanto que do $10 \mathrm{Sc} 0.5 \mathrm{NbSZ}$ chega a $12 \mathrm{mS} / \mathrm{cm}$. 


\section{REFERÊNCIAS}

1. GOODENOUGH, J. Ceramic solid electrolytes. Solid State Ionics, v. 94, p. 17-25, 1997.

2. MUCCILLO, E. N. S. Condutores de íons oxigênio: uma breve revisão. Cerâmica, v. 54, n. 330, p. 129-144, 2008.

3. MINH, N. Q. Ceramic fuel cells. Journal of the American Ceramic Society, v. 76, n. 3, p. 563-588, 1993.

4. QUADAKKERS, W. Compatibility of perovskite contact layers between cathode and metallic interconnector plates of SOFCs. Solid State lonics, v. 91, n. 1-2, p. 55-67, 1996.

5. BADWAL, S. Scandia-zirconia electrolytes for intermediate temperature solid oxide fuel cell operation. Solid State lonics, v. 136-137, p. 91-99, 2000.

6. SHANNON, R. D. Revised effective ionic radii and systematic studies of interatomic distances in halides and chalcogenides. Acta Crystallographica Section A, v. 32, n. 5, p. 751-767, 197.

7. LEE, J. D. Química inorgânica não tão concisa. 5. ed. São Paulo: Blucher. 1999.

8. HEUER, A. H.; HOBBS, L. W. Science and technology of zirconia. Cleveland, Ohio: 1981.

9. LOPES, O. F.; MENDONÇA, V. R.; SILVA, F. B. F.; PARIS, E. C.; RIBEIRO, C. Niobium oxides: an overview of the synthesis of $\mathrm{Nb}_{2} \mathrm{O}_{5}$ and its application in heterogeneous photocatalysis. Química Nova, v. 38, n. 1, p. 106-117, 2014.

10. WEST, R. Solid state chemistry and its applications. Wiley. 1991.

11. FERGUS, J. W. Electrolytes for solid oxide fuel cells. Journal of Power Sources, v. 162, n. 1, p. 30-40, 2006.

12. BADWAL, S. P. S.; CIACCHI, F. T. Oxygen-ion conducting electrolyte materials for solid oxide fuel cells. Ionics, v. 6, n. 1, p. 1-21, 2000.

13. FUJIMORI, H.; YASHIMA, M.; KAKIHANA, M.; YOSHIMURA, M. Structural changes of scandia-doped zirconia solid solutions: Rietveld analysis and Raman scattering. Journal of the American Ceramic Society, v. 81, n. 11, p. 2885-2893, 2005. 
14. XU, G.; ZHANG, Y. W.; LIAO, C. S.; YAN, C. H. Doping and grain size effects in nanocrystalline $\mathrm{ZrO}_{2}-\mathrm{Sc}_{2} \mathrm{O}_{3}$ system with complex phase transitions: XRD and Raman studies. Physical Chemistry Chemical Physics, v. 6, n. 23, p. 5410, 2004.

15. ABDALA, P. M.; FANTINI, M. C. A.; CRAIEVICH, A. F.; LAMAS, D. G. Crystallite size-dependent phases in nanocrystalline $\mathrm{ZrO}_{2}-\mathrm{Sc}_{2} \mathrm{O}_{3}$. Physical Chemistry Chemical Physics, v. 12, n. 12, p. 2822-2829, 2010.

16. ABDALA, P. M.; LAMAS, D. G.; FANTINI, M. C. A.; CRAIEVICH, A. F. Retention at room temperature of the tetragonal t'-form in $\mathrm{Sc}_{2} \mathrm{O}_{3}$-doped $\mathrm{ZrO}_{2}$ nanopowders. Journal of Alloys and Compounds, v. 495, n. 2, p. 561-564, 2010.

17. RUH, R.; GARRETT, H. J.; DOMAGALA, R. F.; PATEL, V. A. The system zirconia-scandia. Journal of the American Ceramic Society, v. 60, n. 9-10, p. 399-403, 1977.

18. NOMURA, K. Aging and Raman scattering study of scandia and yttria doped zirconia. Solid State lonics, v. 132, p. 235-239, 2000.

19. BADWAL, S. An investigation of conductivity, microstructure and stability of electrolyte compositions in the system 9mol\% $\left(\mathrm{Sc}_{2} \mathrm{O}_{3}-\mathrm{Y}_{2} \mathrm{O}_{3}\right)-\mathrm{ZrO}_{2}\left(\mathrm{Al}_{2} \mathrm{O}_{3}\right)$. Solid State Ionics, v. 109, p. 167-186, 1998.

20. HUANG, H.; HSIEH, C. H.; KIM, N.; STEBBINS, J.; PRINZ, F. Structure, local environment, and ionic conduction in scandia stabilized zirconia. Solid State lonics, v. 179, p. 1442-1445, 2008.

21. YASHIMA, M. Metastable-stable phase diagrams in the zirconia-containing systems utilized in solid-oxide fuel cell application. Solid State Ionics, v. 86-88, p. 1131-1149, 1996.

22. TERNER, M. R.; SCHULER, J. A.; MAI, A.; PENNER, D. On the conductivity degradation and phase stability of solid oxide fuel cell (SOFC) zirconia electrolytes analysed via XRD. Solid State Ionics, v. 263, p. 180-189, 2014.

23. ISHII, T.; IWATA, T.; TAJIMA, Y.; YAMAJI, A. Structural phase transition and ion conductivity in $0.88 \mathrm{ZrO}_{2}-0.12 \mathrm{Sc}_{2} \mathrm{O}_{3}$. Solid State Ionics, v. 57, n. 1-2, p. 153-157, 1992.

24. MUCCILLO, E. N. S.; ÁVILA, D. M. Synthesis and characterization of submicron zirconia-12 mol\% ceria ceramics. Ceramics International, v. 25, n. 4, p. 345-351, 1999. 
25. KALISZEWSKI, M. S.; HEUER, A. H. Alcohol interaction with zirconia powders. Journal of the American Ceramic Society, v. 73, n. 6, p. 1504-1509, 1990.

26. SHI, J. L.; GAO, J. H.; LIN, Z. X.; YAN, D. S. Effect of agglomerates in $\mathrm{ZrO}_{2}$ powder compacts on microstructural development. Journal of Materials Science, v. 28, n. 2, p. 342-348, 1993.

27. MERCERA, P. D. L.; OMMEN, J. G.; DOESBURG, E. B. M.; BURGGRAAF, A. J.; ROSS, J. R. H. Influence of ethanol washing of the hydrous precursor on the textural and structural properties of zirconia. Journal of Materials Science, v. 27, n. 18, p. 4890-4898, 1992.

28. MOON, Y. T.; PARK, H. K.; KIM, D. K.; KIM, C. H.; SEOG, I. S. Preparation of monodisperse and spherical zirconia powders by heating of alcohol-aqueous salt solutions. Journal of the American Ceramic Society, v. 78, n. 10, p. 2690-2694, 1995.

29. SONG, Y. L.; TSAI, S. C.; CHEN, C. Y.; TSENG, T. K.; TSAI, C. S.; CHEN, J. W.; YAO, Y. D. Ultrasonic spray pyrolysis for synthesis of spherical zirconia particles. Journal of the American Ceramic Society, v. 87, n. 10, p. 1864-1871, 2005.

30. OKUYAMA, K.; WULED L. I. Preparation of nanoparticles via spray route. Chemical Engineering Science, v. 58, n. 3-6, p. 537-547, 2003.

31. SEGAL, D. Chemical synthesis of ceramic materials. Journal of Materials Chemistry, v. 7, n. 8, p. 1297-1305, 1997.

32. SHI, J. L.; GAO, J. H.; LIN, Z. X.; YEN, T. S. Sintering behavior of fully agglomerated zirconia compacts. Journal of the American Ceramic Society, v. 74, n. 5, p. 994-997, 1991.

33. DRAZIN, J. W.; CASTRO, R. H. R. Phase stability in nanocrystals: a predictive diagram for yttria-zirconia. Journal of the American Ceramic Society, v. 98, n. 4, p. 1377-1384, 2015.

34. DRAZIN, J. W.; CASTRO, R. H. R. Phase stability in calcia-doped zirconia nanocrystals. Journal of the American Ceramic Society, v. 99, p. 1778-1785, 2016.

35. YAO, L.; LIU, W.; OU, G.; NISHIJIMA, H.; PAN, W. Phase stability and high conductivity of ScSZ nanofibers: effect of the crystallite size. Journal of Materials Chemistry A, v. 3, p. 10795-10800, 2015. 
36. OKAMOTO, M.; AKIMUNE, Y.; FURUYA, K.; HATANO, M.; YAMANAKA, M.; UCHIYAMA, M. Phase transition and electrical conductivity of scandiastabilized zirconia prepared by spark plasma sintering process. Solid State lonics, v. 176, n. 7-8, p. 675-680, 2005.

37. ANSELMI T. U.; GARAY, J. E.; MUNIR, Z. A. Fast low-temperature consolidation of bulk nanometric ceramic materials. Scripta Materialia, v. 54, n. 5, p. 823-828, 2006.

38. LEI, Z.; ZHU, Q. Low temperature processing of dense nanocrystalline scandia-doped zirconia (ScSZ) ceramics. Solid State lonics, v. 176, n. 37-38, p. 2791-2797, 2005.

39. TIETZ, F. Structural evolution of Sc-containing zirconia electrolytes. Solid State lonics, v. 100, n. 3-4, p. 289-295, 1997.

40. SPIRIN, A.; IVANOV, V.; NIKONOV, A.; LIPILIN, A.; PARANIN, S.; KHRUSTOV, V.; SPIRINA, A. Scandia-stabilized zirconia doped with yttria: synthesis, properties, and ageing behavior. Solid State lonics, v. 225, p. 448-452, 2012.

41. OMAR, S.; BIN N. W.; CHEN, W.; BONANOS, N. Electrical conductivity of $10 \mathrm{~mol} \% \mathrm{Sc}_{2} \mathrm{O}_{3}-1$ mol\% $\mathrm{M}_{2} \mathrm{O}_{3}-\mathrm{ZrO}_{2}$ ceramics. Journal of the American Ceramic Society, v. 95, n. 6, p. 1965-1972, 2012.

42. YAMAMURA, H.; MATSUSITA, T.; NISHINO, H.; KAKINUMA, K. Co-doping effect on electrical conductivity in the fluorite-type solid-solution systems $\mathrm{Zr}_{0.7}\left(\mathrm{Sc}_{1-\mathrm{x}} \mathrm{M}_{\mathrm{x}}\right)_{0.3} \mathrm{O}_{2-\delta}(\mathrm{M}=\mathrm{Ca}, \mathrm{Mg}, \mathrm{Al}, \mathrm{Gd}, \mathrm{Yb})$. Journal of Materials Science: Materials in Electronics, v. 13, n. 2, p. 57-61, 2002.

43. YANCHEVSKII, O. Z.; PASHKOVA, E. V.; IVANITSKII, V. P.; BELOUS, A. G. Mössbauer and $X$-ray diffraction studies of cubic $\left(\mathrm{ZrO}_{2}\right)_{0.90}\left(\mathrm{Sc}_{2} \mathrm{O}_{3}\right)_{0.10-\mathrm{x}}\left(\mathrm{Fe}_{2} \mathrm{O}_{3}\right)_{\times}$solid solutions. Inorganic Materials, v. 48, n. 6, p. 607-612, 2012.

44. HIRANO, M. Effect of $\mathrm{Bi}_{2} \mathrm{O}_{3}$ additives in Sc stabilized zirconia electrolyte on a stability of crystal phase and electrolyte properties. Solid State lonics, v. 158, n. 3-4, p. 215-223, 2003.

45. ARACHI, Y.; ASAI, T.; YAMAMOTO, O.; TAKEDA, Y.; IMANISHI, N.; KAWATE, K.; TAMAKOSHI, C. Electrical conductivity of $\mathrm{ZrO}_{2}-\mathrm{Sc}_{2} \mathrm{O}_{3}$ doped with $\mathrm{HfO}_{2}, \mathrm{CeO}_{2}$, and $\mathrm{Ga}_{2} \mathrm{O}_{3}$. Journal of the Electrochemical Society, v. 148, n. 5, p. A520-A523, 2001. 
46. LEI, Z.; ZHU, Q. Phase transformation and low temperature sintering of manganese oxide and scandia co-doped zirconia. Materials Letters, v. 61, n. 6 , p. 1311-1314, 2007.

47. PASTOR, M.; PRASAD, A.; BISWAS, K.; PANDEY, A. C.; MANNA, I. Microstructural and impedance study of nanocrystalline lanthana-doped scandia-stabilized zirconia. Journal of Nanoparticle Research, v. 14, n. 8, p. $1-11,2012$.

48. TAO, J.; HAO, Y.; WANG, J. The research of crystal structure and electrical properties of a new electrolyte material: scandia and holmia stabilized zirconia. Journal of the Ceramic Society Japan, v. 121, n. 1411, p. 317-325, 2013.

49. HEEL, A.; VITAL, A.; HOLTAPPELS, P.; GRAULE, T. Flame spray synthesis and characterisation of stabilised $\mathrm{ZrO}_{2}$ and $\mathrm{CeO}_{2}$ electrolyte nanopowders for SOFC applications at intermediate temperatures. Journal of Electroceramics, v. 22, n. 1, p. 40-46, 2007.

50. LAGUNA B. M. A.; SKINNER, S. J.; KILNER, J. A. Performance of solid oxide electrolysis cells based on scandia stabilised zirconia. Journal of Power Sources, v. 192, n. 1, p. 126-131, 2009.

51. ABBAS, H. A.; ARGIRUSIS, C.; KILO, M.; WIEMHOFER, H. D.; HAMMAD, F. F.; HANAFI, Z. M. Preparation and conductivity of ternary scandia-stabilised zirconia. Solid State lonics, v. 184, n. 1, p. 6-9, 2011.

52. OMAR, S.; BONANOS, N. lonic conductivity ageing behaviour of $10 \mathrm{~mol} \%$ $\mathrm{Sc}_{2} \mathrm{O}_{3}-1 \mathrm{~mol} \% \mathrm{CeO}_{2}-\mathrm{ZrO}_{2}$ ceramics. Journal of Materials Science, v. 45, n. 23, p. 6406-6410, 2010.

53. YARMOLENKO, S.; SANKAR, J.; BERNIER, N.; KLIMOV, M.; KAPAT, J.; ORLOVSKAYA, N. Phase stability and sintering behavior of $10 \mathrm{~mol} \% \mathrm{Sc}_{2} \mathrm{O}_{3}-$ $1 \mathrm{~mol} \% \mathrm{CeO}_{2}-\mathrm{ZrO}_{2}$ ceramics. Journal of Fuel Cell Science and Technology, v. 6, n. 2, p. 21007, 2009.

54. SMIRNOVA, A.; et al. Scandia-stabilized zirconia: effect of dopants on surface/grain boundary segregation and transport properties. Symposium AA - Solid State Ionics. Anais: MRS Online Proceedings Library Archive. 2006.

55. GROSSO, R. L.; MUCCILLO, E. N. S. Sintering, phase composition and ionic conductivity of zirconia-scandia-ceria. Journal of Power Sources, v. 233, p. $6-13,2013$. 
56. GROSSO, R. L.; BERTOLETE, M.; MACHADO, I. F.; MUCCILLO, R.; MUCCILLO, E. N. S. Ionic conductivity and phase stability of spark plasma sintered scandia and ceria-stabilized zirconia. Solid State Ionics, v. 230, p. $48-51,2013$.

57. STEELE, B. C. H.; HEINZEL, A. Materials for fuel-cell technologies. Nature, v. 414, n. 6861, p. 345-352, 2001.

58. KOBAYASHI, T.; SASAKI, T.; TAKAGI, I.; MORIYAMA, H. Solubility of zirconium(IV) hydrous oxides. Journal of Nuclear Science and Technology, v. 44 , n. 1, p. 90-94, 2007.

59. KELTER, P.; MOSHER, M.; SCOTT, A. Chemical: the practical science. 1. ed. Boston: Cengage Learning. 2009.

60. ABRAO, A. Química e tecnologia das terras-raras. Rio de Janeiro: CETEM/CNPq, 1994.

61. VOGEL, A. I. Vogel's textbook of macro and semimicro qualitative inorganic analysis. 5. ed. Longman. 1979.

62. BRUNAUER, S.; EMMETT, P. H.; TELLER, E. Adsorption of gases in multimolecular layers. Journal of the American Chemical Society, v. 60, n. 2, p. 309-319, 1938.

63. USHAKOV, S. V.; NAVROTSKY, A. Direct measurements of water adsorption enthalpy on hafnia and zirconia surface using novel design for gas adsorption microcalorimetry. Applied Physics Letters, v. 87, p. 164103, 2005.

64. CASTRO, R. H. R.; QUACH, D. V. Analysis of anhydrous and hydrated surface energies of gamma- $\mathrm{Al}_{2} \mathrm{O}_{3}$ by water adsorption microcalorimetry. Journal of Physical Chemistry C, v. 116, n. 46, p. 24726-24733, 2012.

65. DRAZIN, J. W.; CASTRO, R. H. R. Water adsorption microcalorimetry model: deciphering surface energies and water chemical potentials of nanocrystalline oxides. Journal of Physical Chemistry C, v. 118, n. 19, p. 10131-10142, 2014.

66. NAVROTSKY, A. Progress and new directions in high temperature calorimetry. Physics and Chemistry of Minerals, v. 2, n. 1-2, p. 89-104, 1977.

67. NAVROTSKY, A. Thermodynamics of solid electrolytes and related oxide ceramics based on the fluorite structure. Journal of Materials Chemistry, v. 20, p. $10577,2010$. 
68. BROWN, M. Introduction to thermal analysis, techniques and applications. 2. ed. Holanda: Kluwer Academic Publisher, 2001.

69. HAGENMULLER, P.; GOOL, W. V. Solid electrolytes general principles, characterization, materials, applications. New York: Academic Press. 1978.

70. MENDELSON, M. I. Average grain size in polycrystalline ceramics. Journal of the American Ceramic Society, v. 52, n. 8, p. 443-446, 1969.

71. KLEITZ, M.; KENNEDY, J. H. Resolution of multicomponents impedance diagrams. (P. Vashishta, J. N. Mundy, S. G.K., Eds.) Proceedings of the International Conference on Fast Ion Transport in Solids. Anais. North-Holland, Amsterdam: Electrodes and Electrolytes, 1979.

72. RADHA, A. V.; BOMATI M. O.; USHAKOV, S. V.; NAVROTSKY, A.; TARTAJ, $P$. Surface enthalpy, enthalpy of water adsorption, and phase stability in nanocrystalline monoclinic zirconia. Journal of the American Ceramic Society, v. 92, n. 1, p. 133-140, 2009.

73. ABDALA, P. M.; CRAIEVICH, A. F.; FANTINI, M. C. A.; TEMPERINI, M. L. A.; LAMAS, D. G. Metastable phase diagram of nanocrystalline $\mathrm{ZrO}_{2}-\mathrm{Sc}_{2} \mathrm{O}_{3}$ solid solutions. The Journal of Physical Chemistry C, v. 113, n. 43, p. 18661-18666, 2009.

74. KROGSTAD, J. A.; LEPPLE, M.; GAO, Y.; LIPKIN, D. M.; LEVI, C. G. Effect of yttria content on the zirconia unit cell parameters. Journal of the American Ceramic Society, v. 94, n. 12, p. 4548-4555, 2011.

75. LUO, J.; STEVENS, R. Tetragonality of nanosized 3Y-TZP powders. Journal of the American Ceramic Society, v. 82, n. 7, p. 1922-1924, 1999.

76. BULAVCHENKO, O. A.; VINOKUROV, Z. S.; AFONASENKO, T. N.; TSYRULNIKOV, P. G.; TSYBULYA, S. V.; SARAEV, A. A.; KAICHEV, V. V. Reduction of mixed $\mathrm{Mn}-\mathrm{Zr}$ oxides: in situ XPS and XRD studies. Dalton Transactions, v. 44, n. 35, p. 15499-15507, 2015.

77. STRICKLER, D. W.; CARLSON, W. G. Electrical conductivity in the $\mathrm{ZrO}_{2}$-rich region of several $\mathrm{M}_{2} \mathrm{O}_{3}-\mathrm{ZrO}_{2}$ systems. Journal of the American Ceramic Society, v. 48, n. 6, p. 286-289, 1965.

78. DEVANATHAN, R.; THEVUTHASAN, S.; GALE, J. D. Defect interactions and ionic transport in scandia stabilized zirconia. Physical Chemistry Chemical Physics, v. 11, n. 26, p. 5506-5511, 2009. 
79. QUACH, D. V.; BONIFACIO, A. R.; CASTRO, R. H. R. Water adsorption and interface energetics of zinc aluminate spinel nanoparticles: insights on humidity effects on nanopowder processing and catalysis. Journal of Materials Research, v. 28, n. 15, p. 2004-2011, 2013.

80. SAHU, S. K.; MARAM, P. S.; NAVROTSKY, A. Thermodynamics of nanoscale calcium and strontium titanate perovskites. Journal of the American Ceramic Society, v. 96, n. 11, p. 3670-3676, 2013.

81. CASTRO, R. H. R.; USHAKOV, S. V.; GENGEMBRE, L.; GOUVEA, D.; NAVROTSKY, A. Surface energy and thermodynamic stability of $\gamma$-alumina: effect of dopants and water. Chemistry of Materials, v. 18, p. 1867-1872, 2006.

82. MOLODETSKY, I.; NAVROTSKY, A.; DI S. F.; LERCH, M. Energetics of oxidation of oxynitrides: $\mathrm{Zr}-\mathrm{N}-\mathrm{O}, \mathrm{Y}-\mathrm{Zr}-\mathrm{N}-\mathrm{O}, \mathrm{Ca}-\mathrm{Zr}-\mathrm{N}-\mathrm{O}$, and $\mathrm{Mg}-\mathrm{Zr}-\mathrm{N}-\mathrm{O}$. Journal of Materials Research, v. 15, n. 11, p. 2558-2570, 2000.

83. SIMONCIC, P.; NAVROTSKY, A. Systematics of phase transition and mixing energetics in rare earth, yttrium, and scandium stabilized zirconia and hafnia. Journal of the American Ceramic Society, v. 90, n. 7, p. 2143-2150, 2007.

84. JACOBSON, N. S.; LIU, Z. K.; KAUFMAN, L.; ZHANG, F. Thermodynamic modeling of the $\mathrm{YO}_{1.5}-\mathrm{ZrO}_{2}$ system. Journal of the American Ceramic Society, v. 87, n. 8, p. 1559-1566, 2004.

85. FUJIMORI, H.; YASHIMA, M.; KAKIHANA, M.; YOSHIMURA, M. $\beta$-cubic phase transition of scandia-doped zirconia solid solution: calorimetry, $x$-ray diffraction, and Raman scattering. Journal of Applied Physics, v. 91, n. 10, p. 6493-6498, 2002.

86. GEORGE, A.; SEENA, P. T. Thermal studies on Zirconium hydroxide gel formed by aqueous gelation. Journal of Thermal Analysis and Calorimetry, v. 110, n. 3, p. 1037-1041, 2011.

87. ÁVILA, D. M.; MUCCILLO, E. N. S. Influence of some variables of the precipitation process on the structural characteristics of fine zirconia powders. Thermochimica Acta, v. 256, n. 2, p. 391-398, jun. 1995.

88. MARCOS, P. J. B.; CASTRO, R. H. R.; GOUVEA, D. Estudo de suspensões de zircônia e magnésia em etanol. Cerâmica, v. 47, n. 304, p. 187-192, 2001.

89. MCDEVITT, N. T.; BAUN, W. L. Infrared absorption spectroscopy in zirconia research. Journal of the American Ceramic Society, v. 47, n. 12, p. 622-624, 1964. 
90. STUART, B. Infrared spectroscopy, fundamentals and applications. New York: Wiley. 1964.

91. KOBAYASHI, T.; SASAKI, T.; TAKAGI, I.; MORIYAMA, H. Zirconium solubility in ternary aqueous system of $\mathrm{Zr}(\mathrm{IV})-\mathrm{OH}$-carboxylates. Journal of Nuclear Science and Technology, v. 46, n. 2, p. 142-148, 2009.

92. SHAOQUAN, X. Coordination of scandium with oxalate ions in aqueous medium. Chemical Journal of Chinese Universities, v. 10, n. 6, p. 866-868, 1985.

93. PHILLIPPI, C. M.; MAZDIYASNI, K. S. Infrared and Raman spectra of zirconia polymorphs. Journal of the American Ceramic Society, v. 54, n. 5, p. 254-258, 1971.

94. BADWAL, S. P. S. Effect of dopant concentration on electrical conductivity in the $\mathrm{Sc}_{2} \mathrm{O}_{3}-\mathrm{ZrO}_{2}$ system. Journal of Materials Science, v. 22, n. 11, p. 4125-4132, 1987.

95. BISWAS, K. Impedance spectroscopic behaviour of spark plasma sintered nanocrystalline scandia stabilized zirconia (SSZ). Ceramics International, v. 35, n. 5, p. 2047-2051, 2009.

96. SHIMONOSONO, T.; KIMURA, H.; SAKKA, Y. Effect of grain size on electrical properties of scandia-stabilized zirconia. Journal of the Ceramic Society of Japan, v. 118, n. 1383, p. 1038-1043, 2010.

97. GROSSO, R. L. Densificação e condutividade elétrica da zircônia-escândiacéria. Universidade de São Paulo, 2012.

98. TRUCANO, P.; CHEN, R. Structure of graphite by neutron diffraction. Nature, v. 258, n. 5531 , p. $136-137,1975$.

99. MCDONALD, J. R. Impedance spectroscopy, emphasizing solid materials and systems. New York: Wiley. 1987.

100. BAUERLE, J. E. Study of solid electrolyte polarization by a complex admittance method. Journal of Physics and Chemistry of Solids, v. 30, n. 12, p. 2657-2670, 1969.

101. DU, K.; KIM, C. H.; HEUER, A. H.; GOETTLER, R.; LIU, Z. Structural evolution and electrical properties of $\mathrm{Sc}_{2} \mathrm{O}_{3}$-stabilized $\mathrm{ZrO}_{2}$ aged at $850{ }^{\circ} \mathrm{C}$ in air and wet-forming gas ambients. Journal of the American Ceramic Society, v. 91, n. 5, p. 1626-1633, 2008. 


\section{ANEXO}

Tabela. Tamanho médio de cristalito ( $d$ ) encontrado para as condições de calcinação avaliadas para cada composição de $\mathrm{ZrO}_{2}$ contendo diferentes teores molares de $\mathrm{Sc}_{2} \mathrm{O}_{3}$.

\begin{tabular}{|c|c|}
\hline Calcinação $\left({ }^{\circ} \mathrm{C} / \mathrm{h}\right)$ & $d(\mathrm{~nm})$ \\
\hline \multicolumn{2}{|c|}{$0 \%$} \\
\hline $450 / 2$ & $m=11,7 \pm 1,9 ; t=8,2 \pm 0,7$ \\
\hline $900 / 2$ & $m=21,9 \pm 1,2$ \\
\hline $1100 / 12$ & $m=31,5 \pm 1,8$ \\
\hline $1150 / 12$ & $m=47,0 \pm 2,9$ \\
\hline $1200 / 2$ & $m=57,9 \pm 3,1$ \\
\hline \multicolumn{2}{|c|}{$1,1 \%$} \\
\hline $450 / 0$ & $t=7,1 \pm 0,3$ \\
\hline $500 / 2$ & $t=9,1 \pm 0,3$ \\
\hline $900 / 2$ & $m=10,4 \pm 3,3 ; t=9,7 \pm 0,5$ \\
\hline $1000 / 10$ & $m=26,9 \pm 1,1 ; t=5,1 \pm 0,6$ \\
\hline $1100 / 12$ & $m=30,4 \pm 1,6$ \\
\hline $1200 / 12$ & $m=32,8 \pm 1,4$ \\
\hline \multicolumn{2}{|c|}{$2,1 \%$} \\
\hline $500 / 2$ & $t=7,8 \pm 0,5$ \\
\hline $900 / 2$ & $t=26,4 \pm 1,7$ \\
\hline $1000 / 10$ & $t=17,7 \pm 4,1 ; m=23,6 \pm 1,0$ \\
\hline $1200 / 12$ & $t=37,6 \pm 6,3 ; m=24,8 \pm 1,7$ \\
\hline $1500 / 15$ & $m=33 \pm 1,9$ \\
\hline \multicolumn{2}{|c|}{$3,1 \%$} \\
\hline $500 / 2$ & $t=8,0 \pm 0,5$ \\
\hline $900 / 2$ & $t=24,8 \pm 0,9$ \\
\hline $1300 / 12$ & $t=63,9 \pm 4,8$ \\
\hline \multicolumn{2}{|c|}{$4,2 \%$} \\
\hline $500 / 2$ & $t=7,9 \pm 0,2$ \\
\hline $900 / 2$ & $t=24,2 \pm 1,4$ \\
\hline $1000 / 10$ & $t=40,5 \pm 2,9$ \\
\hline $1200 / 12$ & $t=50,8 \pm 4,8$ \\
\hline \multicolumn{2}{|c|}{$6,2 \%$} \\
\hline $500 / 2$ & $t=7,9 \pm 0,4$ \\
\hline $900 / 2$ & $t=25,1 \pm 1,1$ \\
\hline $1000 / 10$ & $t=41 \pm 2,9$ \\
\hline $1200 / 12$ & $t=48,6 \pm 4,1$ \\
\hline
\end{tabular}




\begin{tabular}{|c|c|}
\hline \multicolumn{2}{|c|}{$8,4 \%$} \\
\hline $500 / 2$ & $c=7,7 \pm 0,3$ \\
\hline $900 / 2$ & $c=29,5 \pm 1,7$ \\
\hline $1000 / 10$ & $c=41,3 \pm 2,3$ \\
\hline $1200 / 12$ & $c=66,6 \pm 5,1$ \\
\hline \multicolumn{2}{|c|}{$10,6 \%$} \\
\hline $500 / 2$ & $c=7,3 \pm 0,5$ \\
\hline $700 / 24$ & $c=12,6 \pm 0,3$ \\
\hline $900 / 2$ & $c=27,2 \pm 1,0$ \\
\hline $1000 / 10$ & $\beta=27,4 \pm 2,7$ \\
\hline $1150 / 12$ & $\beta=50,0 \pm 4,6$ \\
\hline \multicolumn{2}{|c|}{$11,6 \%$} \\
\hline $500 / 2$ & $c=6,7 \pm 0,4$ \\
\hline $600 / 24$ & $c=9,6 \pm 0,2$ \\
\hline $900 / 2$ & $c=26,4 \pm 0,6$ \\
\hline $1000 / 10$ & $\beta=30,8 \pm 3,2$ \\
\hline $1200 / 12$ & $\beta=55,7 \pm 5,1$ \\
\hline \multicolumn{2}{|c|}{$12,9 \%$} \\
\hline $500 / 2$ & $c=5,2 \pm 0,8$ \\
\hline $900 / 2$ & $c=26,7 \pm 1,1$ \\
\hline $1000 / 10$ & $c=23,8 \pm 5,0 ; \beta=37,5 \pm 2,7$ \\
\hline $1200 / 12$ & $c=23,3 \pm 5,6 ; \beta=63,2 \pm 7,1$ \\
\hline $1300 / 24$ & $\beta=62,2 \pm 5,6$ \\
\hline \multicolumn{2}{|c|}{$13,6 \%$} \\
\hline $500 / 2$ & $c=5,1 \pm 0,7$ \\
\hline $700 / 2$ & $c=8,6 \pm 0,2$ \\
\hline $900 / 2$ & $\gamma=28,5 \pm 2,0$ \\
\hline $1150 / 12$ & $\gamma=66,4 \pm 9,2$ \\
\hline $1300 / 24$ & $\gamma=97,5 \pm 7,7$ \\
\hline \multicolumn{2}{|c|}{$14,3 \%$} \\
\hline $500 / 2$ & $c=4,9 \pm 0,8$ \\
\hline $900 / 2$ & $\gamma=35,6 \pm 3,3$ \\
\hline $1000 / 10$ & $\gamma=43,1 \pm 3,9$ \\
\hline $1200 / 12$ & $\gamma=65,4 \pm 5,7$ \\
\hline \multicolumn{2}{|c|}{$19,3 \%$} \\
\hline $500 / 2$ & $c=4,7 \pm 0,3$ \\
\hline $700 / 2$ & $\gamma=9,6 \pm 0,5$ \\
\hline $900 / 2$ & $\gamma=24,8 \pm 2,3$ \\
\hline $1500 / 15$ & $\gamma=77,1 \pm 9,0$ \\
\hline
\end{tabular}

Estruturas: monoclínica $(m)$, tetragonal $(t)$, cúbica $(c)$ e romboédrica $(\beta$ e $\gamma)$. 